\title{
RECONHECIMENTO DA SENTENÇA E DO LAUDO ARBITRAL ESTRANGEIROS
}

MESTRADO EM DIREITO

ORIENTADOR PROFESSOR DOUTOR JOSÉ CARLOS DE MAGALHÃES

FACULDADE DE DIREITO DA UNIVERSIDADE DE SÃO PAULO SÃO PAULO - 2012 


\title{
RECONHECIMENTO DA SENTENÇA E DO LAUDO ARBITRAL ESTRANGEIROS
}

\begin{abstract}
Dissertação apresentada como exigência parcial para a obtenção do Título de Mestre em Direito ao Programa de Pós-graduação em Direito da Faculdade de Direito da Universidade de São Paulo. Área de concentração: Direito Internacional, sob a orientação do Professor Doutor José Carlos de Magalhães.
\end{abstract}

SÃO PAULO 
CARLOS ALBERTO VILELA SAMPAIO

Reconhecimento da sentença e do laudo arbitral estrangeiros

BANCA EXAMINADORA

$\operatorname{Prof}(a) . \operatorname{Dr}(a)$.

$\operatorname{Prof}(a) . \operatorname{Dr}(a)$.

Prof. Dr. José Carlos de Magalhães - Orientador

Trabalho defendido e aprovado pela Comissão Julgadora em $/ 2012$. 
À minha Mãe, Suely Vilela, exemplo de dedicação e caráter, pelo amor e apoio irrestrito $e$ incondicional.

À minha avó Anita, pelo amor e pelas orações que muito me protegeram.

Ao Professor João Grandino Rodas, pela amizade, incentivo e apoio de valor inestimável. 


\section{AGRADECIMENTOS}

Aos meus pais, responsáveis por tudo.

À Kátia pelo amor, compreensão e apoio nos momentos de angústia que as dúvidas causam.

Ao Professor José Carlos de Magalhães, pela confiança e oportunidade de iniciar minha carreira acadêmica.

Aos professores da Faculdade de Direito da Universidade de São Paulo com os quais tive a oportunidade de conviver e muito aprender nesses últimos anos, em especial ao Professor Gustavo Ferraz de Campos Mônaco, que possibilitou amplo aprendizado com a minha participação no Programa de Aperfeiçoamento de Ensino. 


\section{RESUMO}

SAMPAIO, Carlos Alberto Vilela. Reconhecimento da sentença e do laudo arbitral estrangeiros. 2012. 175 p. Dissertação (Mestrado em Direito) - Faculdade de Direito da Universidade de São Paulo, São Paulo, 2012.

Diferentemente do que ocorre na área pública, na qual tanto a Corte Internacional de Justiça (CIJ) quanto a Dispute Solution Board (DSB) da OMC estão aptas a solucionar os conflitos internacionais públicos, na área jurídica privada não é viável, no mundo contemporâneo, imaginar a existência de um modelo supranacional e global para a solução de litígios privados internacionais que se guiasse por normas processuais próprias e aplicasse normas materiais unificadas internacionalmente. Assim, cada país estabelece seu poder jurisdicional dentro de seu próprio território e nos limites postos pelo direito internacional, de modo que, atualmente, exceto nos casos em que se convencionar a solução do conflito pela via da arbitragem, será sempre um tribunal nacional que decidirá o litígio de caráter internacional. Haverá, evidentemente, casos em que as decisões proferidas em tribunais nacionais não apresentarão aptidão para garantir a efetivação dos interesses tutelados, fazendo-se necessário que parte ou a totalidade dos efeitos práticos da sentença sejam produzidos em outros sistemas jurídicos, ocasião em que, salvo convenções e tratados internacionais, haverá a necessidade de seu reconhecimento, por meio do processo de homologação, para que possa ser executada. Busca este trabalho demonstrar que nem todos os efeitos da sentença dependem do procedimento de homologação para que se manifestem. Por outro lado, a Lei de Arbitragem, ao equiparar em efeitos laudos arbitrais a sentenças estatais, consequentemente impõe ao laudo arbitral estrangeiro o seu reconhecimento por meio do processo de homologação pelo Superior Tribunal de Justiça, para que, só então, possa ser executado. Tal medida legislativa parece desconsiderar a distinção entre sentença judicial e laudo arbitral, este de natureza privada, que não decorre da prestação jurisdicional de um Estado, mas sim proferido por pessoas despidas de qualquer autoridade pública, cujo poder jurisdicional provém de convenção privada das partes. Em resposta a essa situação, propõe-se este trabalho demonstrar a diferença entre laudo e sentença, no intuito de eliminar a exigência legal da homologação dos laudos arbitrais estrangeiros pelo Superior Tribunal de Justiça, sem contudo retirar-lhes os efeitos, o que se daria pela limitação das matérias de defesa no processo de execução de títulos executivos extrajudiciais.

Palavras-chaves: Reconhecimento - Sentença estrangeira - Laudo arbitral estrangeiro. 


\begin{abstract}
SAMPAIO, Carlos Alberto Vilela. Recognition of the foreign sentence and arbitral award. 2012. 175 p. Dissertation (Master Degree in Law) - Faculdade de Direito da Universidade de São Paulo, São Paulo, 2012.

Differently of what it happens in the public area, in the which both the International Court of Justice (CIJ) and the Dispute Solution Board (DSB) of OMC are capable to solve the public international conflicts, in the private juridical area it is not viable, in the contemporary world, to imagine the existence of a supranational and global model for the solution of private international litigations guided by own procedural norms and applied material norms internationally unified. Thus, each country establishes its jurisdictional power inside its own territory and into the limits put by the international law, so that, now, except in the cases that the solution of the conflict is stipulated by the means of arbitration, it will always be a national court that will decide the international litigations. There will be, evidently, cases in which the pronounced decisions by national courts wil not present aptitude to guarantee the efectiveness of the tutored interests, being necessary that part or the totality of the practical effects of the sentence are produced in other juridical systems, occasion in that, except for conventions and international agreements, there will be the need of its recognition, through the approval process, so that it can be executed. This work aims to demonstrate that not all the effects of the sentence depend on the approval procedure to be shown. On the other hand, the Law of Arbitration, when matching in effects arbitral awards to public sentences, consequently imposes to the foreign arbitral award its recognition by the means of the approval process by the Superior Tribunal of Justice, so that, only then, it can be executed. Such a legislative measure seems to disrespect the distinction between judicial sentence and arbitral award, this of private nature, that doesn't elapse from the jurisditional rendering of a State, but is pronounced by people without any public authority, whose jurisdictional power comes from the private convention of the parts. In response to that situation, this work intends to demonstrate the difference between arbitral award and sentence, in the intention to eliminate the legal demand of the approval of the foreign arbitral awards by the Superior Tribunal of Justice, without however removing their effects, what would de done by the limitation of the defense matters in the process of execution of extrajudicial executive titles.
\end{abstract}

Keywords: Recognition - Foreign sentence - Foreign arbitral award 


\section{SUMÁRIO}

INTRODUÇÃO 10

\section{CAPÍTULO I - RECONHECIMENTO DA SENTENÇA E DO LAUDO ARBITRAL} ESTRANGEIRO: CONSIDERAÇÕES GERAIS ..................................... 15

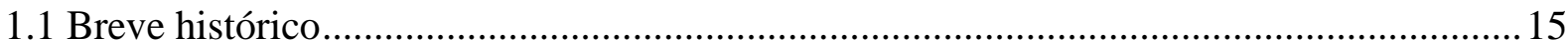

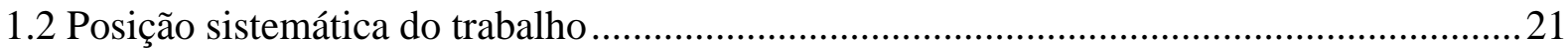

1.3 Avocação de jurisdição internacional: ato de soberania na fixação da jurisdição.............. 23

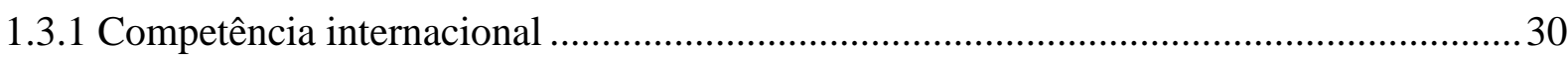

1.3.2 Autonomia da vontade e modificação da competência internacional ............................ 43

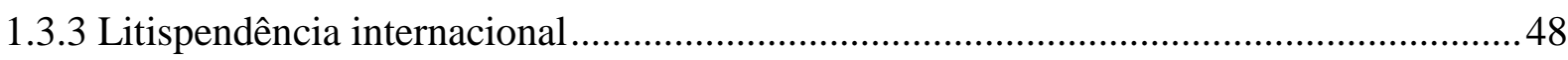

1.3.4 Princípios que informam as regras de competência internacional .................................52

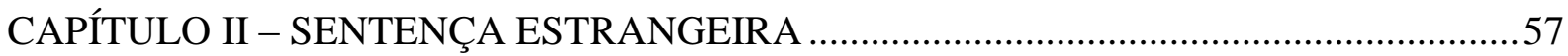

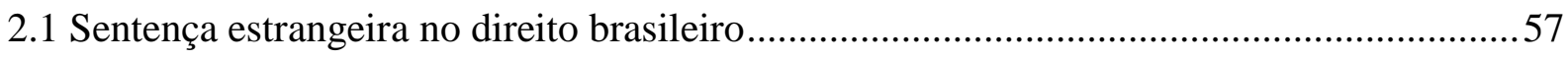

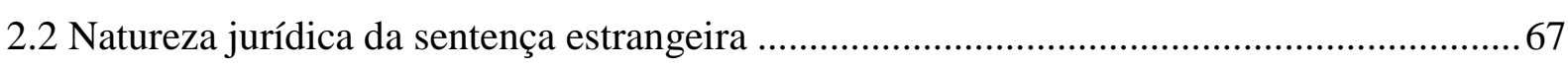

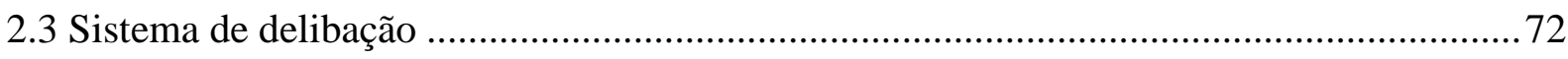

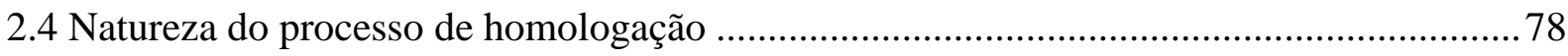

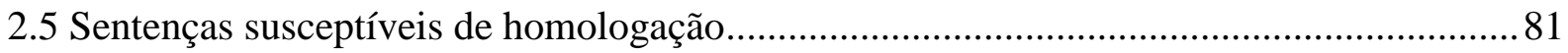

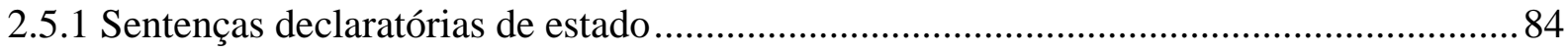

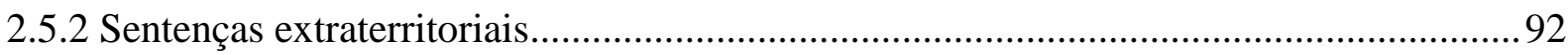

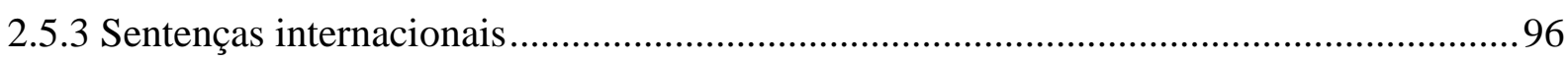

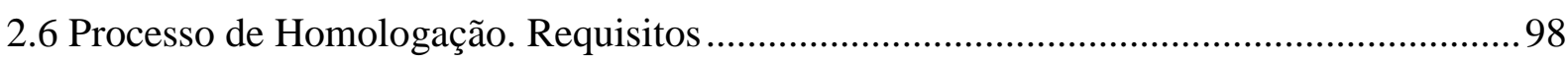

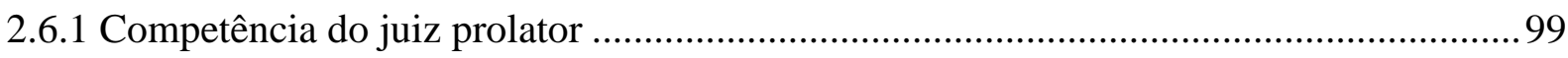

2.6.2 Citação válida do réu ou a configuração legal da revelia ................................................99

2.6.3 Trânsito em julgado do ato sentencial homologando, bem o cumprimento das

formalidades necessárias à sua execução no lugar em que foi proferido ........................ 100

2.6.4 Autenticação pelo consulado brasileiro e tradução oficial dos documentos .................. 101

2.6.5 Não contrariedade à ordem pública, soberania nacional e aos bons costumes...............102

CAPÍTULO III - LAUDO ARBITRAL ESTRANGEIRO............................................. 104

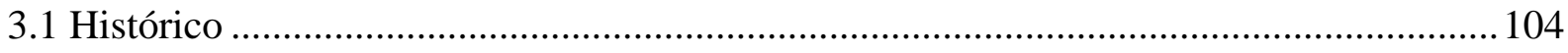

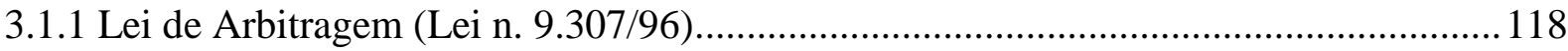


3.2 Natureza jurídica do laudo arbitral estrangeiro. O equívoco da lei

3.2.1 A inconstitucionalidade do artigo 35

3.3 A ratificação da Convenção de Nova Iorque e seus efeitos sobre a homologação do laudo arbitral estrangeiro

3.3.1 O tratamento conferido ao laudo arbitral estrangeiro .............................................. 150

3.4 Processo de homologação. Hipóteses de indeferimento.................................................. 152

3.4.1 As partes na convenção de arbitragem eram incapazes.

3.4.2 A convenção de arbitragem não era válida segundo a lei à qual as partes se submeteram, ou, na falta de indicação, em virtude da lei do país onde a sentença arbitral foi proferida.

3.4.3 Não foi notificado da designação do árbitro ou do procedimento de arbitragem, ou tenha sido violado o princípio do contraditório, impossibilitando a ampla defesa

3.4.4 A sentença arbitral foi proferida fora dos limites da convenção de arbitragem, e não foi possível separar a parte excedente daquela submetida à arbitragem

3.4.5 A instituição da arbitragem não está de acordo com o compromisso arbitral ou com cláusula compromissória

3.4.6 A sentença arbitral não se tenha, ainda, tornado obrigatória para as partes, tenha sido anulada, ou, ainda, tenha sido suspensa por órgão judicial do país onde a sentença arbitral for prolatada 158

3.4.7 Se segundo a lei brasileira, o objeto do litígio não é suscetível de ser resolvido por arbitragem

3.4.8 A decisão ofende a ordem pública nacional 160

3.4.9 Citação e a ordem pública nacional

CONCLUSÃO 162 


\section{INTRODUÇÃO}

Diferentemente do que ocorre na área pública, na qual tanto a Corte Internacional de Justiça (CIJ) quanto a Dispute Solution Board (DSB) da OMC estão aptas a solucionar os conflitos internacionais públicos, na área jurídica privada não há nenhum organismo judiciário internacional estruturado nos mesmos moldes para a solução de litígios de tal natureza.

Nem é viável, no mundo contemporâneo, imaginar a existência de um modelo supranacional e global para a solução de litígios privados internacionais que se guiasse por normas processuais próprias e aplicasse normas materiais unificadas internacionalmente, não obstante tal modelo pudesse viabilizar a efetivação da decisão por esse órgão proferida. $\mathrm{Na}$ medida que não há tal sistema internacional, aos particulares resta a alternativa de bem manejar os sistemas processuais nacionais, suas jurisdições, e, por vezes, a diversidade entre os elementos de conexão indicados pelos direitos internacionais privados em voga.

Cada país estabelece seu poder jurisdicional dentro de seu próprio território e nos limites postos pelo direito internacional, de modo que, atualmente, exceto nos casos em que se convencionar a solução dos conflitos privados pela via da arbitragem, será sempre um tribunal nacional que decidirá o litígio de caráter internacional.

Haverá, evidentemente, casos em que as decisões proferidas em tribunais nacionais não apresentarão aptidão para garantir a efetivação dos interesses tutelados, fazendo-se necessário que parte ou a totalidade dos efeitos práticos da sentença sejam produzidos em outros sistemas jurídicos. Ocorre que a jurisdição, como função do Estado, é ato de soberania e, por isso, adstringe-se aos seus limites territoriais. Haverá, então, salvo convenções e tratados internacionais que versem sobre o tema, a necessidade de seu reconhecimento, através do processo de homologação, para que tais decisões possam ser executadas nesses outros territórios.

Entretanto, notadamente a partir da segunda metade do século XX, o comércio internacional vem crescendo extraordinariamente e a arbitragem comercial internacional adquiriu enorme prestígio como mecanismo extrajudicial de solução de controvérsias e 
litígios comerciais internacionais, de modo que a regulamentação do reconhecimento do laudo arbitral estrangeiro não cumprido voluntariamente passou a interessar mais de perto aos países que pretendem fazerem-se presentes no comércio internacional.

A arbitragem, portanto, vem se mostrando especializada nas regras e práticas do comércio internacional, estando capacitada a dar uma rápida e competente solução para tais pendências.

Entretanto, não raras vezes a decisão arbitral deve defrontar-se com judiciários que, inicialmente, buscava evitar, sobretudo nos casos em que há o descumprimento do comando contido no laudo arbitral, situação que se agrava quando o laudo é emitido no exterior, portanto estrangeiro. A Lei de Arbitragem, ao equiparar, em efeitos, laudos arbitrais a sentenças estatais, consequentemente, impõe aos laudos arbitrais confeccionados fora do território nacional o seu reconhecimento por meio do processo de homologação pelo Superior Tribunal de Justiça, para que, só então, possa ser executado.

Ao lado da tentativa de sistematizar a problemática do reconhecimento da sentença e do laudo arbitral estrangeiros, o presente estudo demonstrará as diferenças existentes entre laudo arbitral e sentença judicial, sobretudo em razão da origem da jurisdição dos árbitros ser distinta da origem da jurisdição do juiz togado, ou seja, que o laudo arbitral não se reveste dos mesmos atributos da sentença estatal para que possa produzir os mesmos efeitos e ter a mesma força, posto que de naturezas distintas.

Consequentemente, não necessitaria, o laudo arbitral estrangeiro, do processo de homologação pelo Superior Tribunal de Justiça, como ocorre com a sentença estatal proveniente do poder jurisdicional de outro Estado soberano, para que se autorize sua execução no ordenamento jurídico brasileiro, posto que, como se demonstrará, é título executivo extrajudicial, e portanto hábil a instaurar um procedimento executório sem a necessidade do procedimento de homologação pelo Superior Tribunal de Justiça.

Não se busca a completa exclusão da arbitragem nacional ou internacional de todas as formas de intervenção estatal, pois não raras vezes, ainda no curso do procedimento arbitral, a intervenção estatal é necessária para a garantia da própria arbitragem. São inúmeras as possibilidades que podem ensejar essa intervenção: levantamento, apuração ou congelamento 
de contas bancárias, medidas cautelares em geral e alegação de parcialidade do árbitro, tudo sem mencionar a execução forçada do laudo prolatado.

O reconhecimento de sentenças e laudos arbitrais estrangeiros são aqui analisados sob o enfoque do direito internacional para, primeiro, esclarecer os atributos essenciais das sentenças estatais e dos laudos arbitrais, no intuito de diferenciá-los, sobretudo quanto à origem da jurisdição conferida ao julgador, com a finalidade de demonstrar que a Lei de Arbitragem não deveria tê-los equiparados nos efeitos para a consecução do objetivo colimado pelo legislador, pois substancialmente diferentes, e, ainda, demonstrar, em razão dessas diferenças, a desnecessidade da homologação do laudo arbitral estrangeiro.

É indiscutível que a regulamentação introduzida pela Lei de Arbitragem visa a prestigiar e tornar mais eficaz esse meio extrajudicial de solução de controvérsias. Não se discutem as benesses trazidas pela Lei de Arbitragem. O que a presente pesquisa busca é propor avanços.

Notadamente, não apenas essa questão é tratada. Na medida que o tema está intimamente relacionado ao direito processual, também tratou-se dos institutos afins ao tema central.

O capítulo I apresenta algumas considerações gerais ao tema do reconhecimento da sentença e do laudo arbitral estrangeiros, com foco no direito internacional, no qual é traçado um breve histórico do surgimento da preocupação com a regulamentação do reconhecimento de julgados proferidos fora do território do Estado, bem como a evolução das teorias que justificaram a aceitação do julgado fora do território do foro. Estabelece-se, a partir do esboço histórico apresentado, a posição sistemática do trabalho.

Na medida que a competência internacional do juiz brasileiro está inexoravelmente relacionada à homologação de sentenças estrangeiras, trata-se a avocação de competência internacional como ato de soberania na fixação da jurisdição. São abordadas as regras de competência internacional da autoridade judiciária brasileira, suas consequências quanto à homologação dessas sentenças, bem como a influência da autonomia da vontade das partes nas regras de competência internacional, e, por fim, a litispendência e os princípios da competência internacional. 
No capítulo II, procuramos sistematizar a regulamentação do reconhecimento da sentença estrangeira, também com enfoque no direito internacional, objetivando esclarecer, inicialmente, a natureza da sentença estrangeira antes de homologada, demonstrando a sua coerência com o sistema de delibação adotado no Brasil para o reconhecimento dos julgados estrangeiros, que define a natureza do processo de homologação e reflete a coerência do parágrafo único do artigo 15 da Lei de Introdução às Normas do Direito Brasileiro com o sistema de delibação, demonstrando, ainda, que nem todos os efeitos da sentença estrangeira ficam subordinados à sua prévia homologação pelo Superior Tribunal de Justiça.

Nesse capítulo tratamos também das sentenças extraterritoriais a que se refere o artigo 20 do Protocolo de Las Leñas, as sentenças do Mercosul. É estudado o Protocolo de Las Leñas que, em seu capítulo $\mathrm{V}$, trata do reconhecimento e execução das sentenças e laudos arbitrais estrangeiros. Do mesmo modo, são abordadas as sentenças internacionais, as proferidas por tribunais internacionais dos quais o Brasil faz parte.

Essa explanação, no entanto, é precedida de um breve histórico sobre o reconhecimento da sentença estrangeira no Brasil e culmina na análise dos requisitos estabelecidos pela legislação reputados como indispensáveis para que se homologue a sentença estrangeira em território nacional.

O capítulo III versa sobre o laudo arbitral estrangeiro. Procuramos, incialmente, traçar um breve histórico da arbitragem no Brasil, bem como da evolução da interpretação dada pelos tribunais competentes à homologação de laudos arbitrais estrangeiros. Posteriormente estabelecem-se, através da conceituação da natureza jurídica do laudo arbitral estrangeiro, os atributos que o caracterizam como ato jurídico privado, no intuito de diferenciá-lo da sentença estatal, e bem assim as consequências e equívocos da conduta do legislador com relação à equiparação feita pela Lei de Arbitragem.

Ainda nesse capítulo são objeto de estudo os efeitos da ratificação pelo Brasil da Convenção de Nova Yorque sobre o reconhecimento do laudo arbitral estrangeiro, sobretudo à luz do princípio da lex posteriori derogat priori. 
Por fim, trazemos nossas conclusões sobre a pesquisa desenvolvida, direcionada a uma melhor interpretação e manejo dessas regras, com o intuito de facilitar a integração jurídica, econômica, social e política do Brasil com os demais países.

A presente pesquisa busca uma interpretação tendente a dar uma maior efetividade às decisões que tenham de ser cumpridas no Brasil, interpretação que se deu dentro do contexto dos objetivos do direito internacional privado, ou seja, visando à estabilidade da vida privada internacional e à manutenção da justiça internacional, almejando sempre satisfazer as necessidades de estabilidade (segurança jurídica) e de justiça da sociedade internacional, no sentido de adequar a legislação e sua interpretação ao cenário econômico, político e social vigente e em constante mutação. 


\section{CAPÍTULO I - RECONHECIMENTO DA SENTENÇA E DO LAUDO ARBITRAL ESTRANGEIRO: CONSIDERAÇÕES GERAIS}

\subsection{Breve histórico}

Historicamente, pode-se dizer que o direito romano não tratou do tema, tendo em vista que o ius civile era o único direito aplicável ao território e que, nas circunstâncias em que a presença de um estrangeiro tornasse desaconselhável ou até mesmo inviável a aplicação do ius civile, concebia-se o ius gentium ${ }^{1}$, que na realidade consistia num direito para estrangeiros, e não em um direito estrangeiro ${ }^{2}$. Amilcar de Castro $^{3}$ afirma que "até o que se pode dizer é que o ius gentium era a negação do direito internacional privado, já que se destinava à direta apreciação de relações estabelecidas entre peregrinos". Vicente Greco Filho ${ }^{4}$ afirma, com base em Luigi Condorelli, que nem mesmo a codificação justinianeia continha normas a respeito.

Muito embora o imperador Caracala, no século III, tenha estendido a aplicação do ius civile a todos os habitantes do Império Romano, não haveria de se cogitar da aplicação do direito estrangeiro, da sentença estrangeira e tampouco de seu reconhecimento e execução, seja pelo fato de haver um único direito aplicável a todos os habitantes do Império seja pela aplicação, anteriormente, do ius gentium aos estrangeiros ou peregrinos. ${ }^{5}$

A doutrina feudal do século IX, por sua vez, impregnada pelo territorialismo absoluto e considerando o homem mero acessório da terra onde se encontrava, admitia a fusão da soberania com a propriedade, resultando invariavelmente em uma concepção muito territorialista do direito, de modo que não havia se falar em aplicação de direito estrangeiro. Havia um predomínio quase que exclusivo das leis vigentes no território, não se verificando,

\footnotetext{
${ }^{1}$ Amílcar de Castro afirma que em Roma, ao lado dos estrangeiros, havia também os peregrinos, tidos como súditos, de modo que, também, a eles não era aplicado o ius civile romanorum, mas um direito especial, denominado ius gentium. (Direito internacional privado. 5. ed., 5. tiragem, atual. pelo prof. Osiris Rocha. Rio de Janeiro: Forense, 2000. p. 130).

2 HUCK, Hermes Marcelo. Sentença estrangeira e lex mercatoria: horizontes e fronteiras do comércio internacional. São Paulo: Saraiva, 1994. p. 2.

${ }^{3}$ CASTRO, Amílcar de, Direito internacional privado, cit., p. 131. Ver também: DOLINGER, Jacob. Direito internacional privado: parte geral. 9. ed. atual. Rio de Janeiro: Renovar, 2008. p. 128-129.

${ }^{4}$ GRECO FILHO, Vicente. Homologação de sentença estrangeira. São Paulo: Saraiva, 1978. p. 5.

${ }^{5}$ MIAJA DE LA MUELA, Adolfo. Derecho internacional privado. 6. ed. Madrid: Atlas, 1972. p. 86.
} 
assim, nenhum conflito de leis, de modo que não se desenvolveram, portanto, nesse período, preocupações com o alcance extraterritorial dos efeitos da sentença. ${ }^{6}$

A partir do século XI, as cidades do Norte de Itália, como Módena, Bolonha, Florença, Pádua, Gênova e Veneza, onde não havia um regime feudal muito acentuado, desenvolveram intenso movimento mercantil interurbano ${ }^{7}$. Essas cidades, muito embora sujeitas ao domínio do Império Germânico, mantinham elevado grau de soberania e autonomia e começaram a reduzir por escrito seu direito consuetudinário e a firmar seus estatutos, surgindo em razão disso, e em decorrência do intenso comércio entre as cidades mais próximas, corriqueiro conflito de leis ${ }^{8}$. A par disso, vinha se desenvolvendo o estudo do direito em universidades, como a de Bolonha. ${ }^{9}$

Surge, então, terreno fértil para o nascimento do direito internacional privado. Com Bártolo de Sassoferrato, Baldo e Saliceto nasce a Escola Estatutária Italiana (séculos XIV e $\mathrm{XV})^{10}$. Bártolo de Sassoferrato, em trabalho pioneiro de sistematização dos estudos realizados pelos glosadores, construiu uma teoria destinada a regular a aplicação do direito estrangeiro, tendo Baldo e Saliceto seguido seus estudos e aprofundado a análise da sentença estrangeira, chegando a admitir a eficácia da sentença penal em outros territórios, afirmando, inclusive, que as penas restringiam a capacidade das pessoas, seguindo-as assim como a lepra seguia o leproso. $^{11}$

Pode-se dizer, dessa forma, que os contornos mais definidos da problemática da eficácia, em determinado ordenamento, dos elementos jurídicos formulados no ordenamento

\footnotetext{
${ }^{6}$ DOLINGER, Jacob, Direito internacional privado: parte geral, cit., p. 131; GRECO FILHO, Vicente, Homologação de sentença estrangeira, cit., p. 6; HUCK, Hermes Marcelo, Sentença estrangeira e lex mercatoria: horizontes e fronteiras do comércio internacional, cit., p. 2.

${ }^{7}$ DOLINGER, Jacob, op. cit., p. 132.

${ }^{8}$ Jacob Dolinger, com base em Karl Neumeyer, cita um parecer de Aldricus, tido como um dos documentos mais antigos que versava sobre conflito de lei: "Mas, pergunta-se: se homens de diversas províncias, as quais tem diversos costumes, litigam perante um mesmo juiz, qual desses costumes deve seguir o juiz que recebeu o feito para ser julgado? Respondo: deve seguir o costume que lhe parecer mais preferível e mais útil, porque deve julgar conforme aquilo que a ele, juiz, for visto como melhor (qua potior et utilior videtur). De acordo com Aldricus." (Direito internacional privado: parte geral, cit., p. 132).

${ }^{9}$ HUCK, Hermes Marcelo, Sentença estrangeira e lex mercatoria: horizontes e fronteiras do comércio internacional, cit., p. 3.

${ }^{10}$ STRENGER, Irineu. Curso de direito internacional privado. Rio de Janeiro: Forense, 1978. p. 227; VALLADÃO, Haroldo. Direito internacional privado: em base histórica e comparativa, positiva e doutrinária, especialmente dos estados americanos: introdução e parte geral. 3. ed. rev. e atual. Rio de Janeiro: Freitas Bastos, 1971. v. 1, p. 110.

${ }^{11}$ HUCK, Hermes Marcelo, op. cit., p. 3.
} 
jurídico de países estrangeiros veio a ser tratado com mais acuidade e de forma pioneira pela Escola Estatutária Italiana nos séculos XIV e XV.

Mostrava-se, por meio desses trabalhos, que o conceito de jurisdição soberana começara a admitir, sob o fundamento de um direito comum (ius commune), a hipótese de aplicação no foro de outra lei que não a do próprio território, abrindo-se, consequentemente, a possibilidade de conflito de leis no espaço e, com isso, a necessidade de um conjunto de regras para solucioná-lo. Nasce, então, a partir da admissão da possibilidade de aplicação da lei estrangeira em outro ordenamento jurídico, o direito internacional privado ${ }^{12}$. Diz-se, por isso, que a história do reconhecimento da sentença estrangeira se confunde com a evolução do direito internacional privado.

Nessa época, apogeu do período estatutário, a validade da sentença extra territorium judicantis fundava-se no ius commune. Consubstanciava-se a sentença estrangeira na emanação de um direito comum.

Em sequência aos estudos realizados pela Escola Italiana, surge assim, no século XVI, a Escola Estatutária Francesa, cujos principais expoentes foram Charles Dumoulin e Bernard D’Argentré. Dumoulin, seguindo os estudos de Bártolo, admitia a eficácia da sentença estrangeira, ao aceitar a aplicação do direito estrangeiro como resultado de um processo de internacionalização das relações comerciais. ${ }^{13}$

No entanto, a partir do fim da Idade Média, a progressiva consolidação das soberanias dos Estados levou à repulsa de qualquer poder, inclusive o poder jurisdicional, que não o nacional, trazendo significativas modificações à problemática da eficácia extraterritorial das sentenças. Essa era a posição adotada por D’Argentré, grande defensor da teoria do territorialismo $^{14}$, que retomando a visão feudal do direito, entendia que os atos praticados por um Estado se aplicavam, com exclusividade, no estrito âmbito do território do Estado, não

\footnotetext{
${ }^{12}$ CASTRO, Amílcar de, Direito internacional privado, cit., p. 127-128; STRENGER, Irineu, Curso de direito internacional privado, cit., p. 225-234; VALLADÃO, Haroldo, Direito internacional privado, cit., v. 1, p. 108-111.

${ }^{13}$ HUCK, Hermes Marcelo, Sentença estrangeira e lex mercatoria: horizontes e fronteiras do comércio internacional., cit., p. 4; VALLADÃO, Haroldo, op. cit., v. 1, p. 113-114.

${ }^{14}$ DOLINGER, Jacob, Direito internacional privado: parte geral, cit., p. 137.
} 
admitindo a aplicação do direito estrangeiro e tampouco a possibilidade de reconhecimento da sentença oriunda de outro foro. ${ }^{15}$

Por outro lado, as exigências resultantes da necessidade da convivência internacional entre os povos fizeram com que se passasse a admitir a possibilidade de se dar eficácia a julgados oriundos de outras jurisdições. Porém, não se fazia mais possível invocar um suposto direito superior, o ius commune, para justificar e sustentar a eficácia extraterritorial dos julgados. Recorreu-se, a partir de então, à teoria da comitas gentium, segundo a qual, como afirma Marnoco e Souza ${ }^{16}$, a legislação de outros povos deveria ainda ser repelida, sob o fundamento do Poder Legislativo do Estado acabar nas suas fronteiras, entretanto, cada Estado, em decorrência dos inúmeros inconvenientes que daí advinham, e em razão de uma concepção de justiça e equidade, decidiria, por vontade espontânea, atribuir validade e eficácia a sentenças oriundas de outros países em seu território.

Sua adoção equivaleria a submeter o reconhecimento das sentenças forasteiras ao arbítrio dos Estados, que poderiam simplesmente, conforme lhes fosse conveniente, revogar seus atos de cortesia. Críticas não lhe faltaram. Alegava-se que a comitas gentium marcava-se por vagueza, equivocidade e inexatidão. José Ferreira Marnoco e Souza ${ }^{17}$ chega a afirmar que “a comitas gentium é uma noção vaga, variável e incerta, e por isso de nada vale como fundamento da doutrina da execução extraterritorial das sentenças".

A grande rejeição à concepção, predominante na Idade Média, de que havia um ius commune a sustentar a eficácia extraterritorial das sentenças estrangeiras, fez surgir, dentre outras $^{18}$, as teorias do quase contrato, da lei especial e da comunidade do direito.

Havia, assim, quem encontrasse fundamento para o reconhecimento das sentenças estrangeiras na teoria do quase contrato jurídico ou, simplesmente, contrato. Partia-se da

${ }^{15}$ GRECO FILHO, Vicente, Homologação de sentença estrangeira, cit., p. 7; HUCK, Hermes Marcelo, Sentença estrangeira e lex mercatoria: horizontes e fronteiras do comércio internacional., cit., p. 4.

${ }^{16}$ SOUZA, José Ferreira Marnoco e. Execução extraterritorial das sentenças civeis e commerciaes. Coimbra: F. França Amado, 1898. p. 28 et seq.

${ }^{17}$ SOUZA, José Ferreira Marnoco e, op. cit., p. 26. Entre nós, no mesmo sentido, podemos citar Amílcar de Castro (Das execuções de sentenças estrangeiras no Brasil. Belo Horizonte: Imprensa Oficial de Minas Gerais, 1939. p. 29) e Vicente Greco Filho, que acrescenta ainda: "A doutrina da comitas gentium, como é evidente, tem apenas valor histórico e não poderia resistir por muito tempo como fundamentadora da aplicação extraterritorial de leis ou sentenças de outros países" (Homologação de sentença estrangeira, cit., p. 8).

${ }^{18}$ Vicente Greco Filho afirma que, à semelhança do que ocorreu com a teoria da comitas gentium, também foram superadas as doutrinas do quase contrato e da lei especial (op. cit., p. 8). 
premissa de que as partes, ao se submeterem de forma voluntária ao poder estatal, representado na figura do magistrado, assumiam a obrigação de respeitar em qualquer território, que não o do foro, o resultado daquela prestação jurisdicional.

Sustentavam seus defensores, em razão disso, que o reconhecimento de uma sentença estrangeira em seu território não importava submissão à soberania do Estado prolator da sentença homologanda, apenas o acolhimento de um acordo de vontades pelo Poder Judiciário do Estado no qual se pretendia a homologação. ${ }^{19}$

Críticas também não lhe faltaram. A sentença, fruto do poder jurisdicional, corolário da soberania estatal, constitui inegavelmente ato de soberania, pelo que se impõe às partes por força da lei, e não em decorrência da autonomia volitiva. Desse modo, na medida que de natureza e essências distintas, inapropriado se mostrou equiparar sentença a contrato, ou mesmo contrato à sentença, como até hoje pretendem alguns, o que será abordado mais à frente. $^{20}$

A teoria da lei especial procurou fundamentar o reconhecimento da eficácia da sentença estrangeira no fato de que ela não seria outra coisa senão uma lei especial material, quando comparada às normas gerais e abstratas, e, portanto, se submeteria às mesmas regras e princípios da aplicação extraterritorial das leis de direito material.

Ora, com isso surgiria para o juiz sentenciante a obrigação de ter aplicado, ou de aplicar no momento da sentença, a norma material indicada pelas regras que regem o conflito de lei aplicável - normas típicas de direito internacional privado - do Estado em que se pretenda o reconhecimento da sentença. Havia ainda a possibilidade, hoje muito comum, do juiz prolator da sentença a ser reconhecida pertencer a Estado diverso daquele apontado como o da lei material aplicável pelas regras de conflito do Estado em que se busca o reconhecimento. Notória sua incoerência, pelo que foi superada. ${ }^{21}$

Por sua vez, a teoria da comunidade do direito, capitaneada por Savigny e Mancini, sustentava-se na ideia de um dever de reconhecimento dos atos jurídicos estrangeiros.

\footnotetext{
${ }^{19}$ SOUZA, José Ferreira Marnoco e, Execução extraterritorial das sentenças civeis e commerciaes, cit., p. 28.

${ }^{20}$ Ibidem, p. 29-30.

${ }^{21}$ Ibidem, p. 30-32.
} 
Savigny entendia essa comunidade como fruto do aumento das relações internacionais, que impunha a renúncia ao princípio da exclusividade e a adoção de um princípio voltado à assimilação de direitos entre nacionais e estrangeiros, para estabelecer uma igualdade reclamada pelo interesse dos povos e dos indivíduos e gerar uma crescente comunhão entre os diversos Estados independentes. Para Mancini, a ideia de comunidade do direito tinha como fundamento a sociabilidade da natureza humana, que gerava um dever de justiça internacional que os Estados não podiam violar, sob pena de se tornarem membros rebeldes e refratários dessa comunidade universal. ${ }^{22}$

Para José Ferreira Marnoco e Souza ${ }^{23}$, essa teoria, além de vaga, era confusa e indeterminada. No entanto, tem-se como legado da teoria da comunidade do direito a percepção da ineficiência e da inconveniência de se fundamentar o reconhecimento das sentenças estrangeiras em razões de justiça e equidade (comiter), baseadas, simplesmente, na vontade arbitrária do soberano. Porém, para os adeptos da teoria da comunidade do direito, a eficácia extraterritorial das sentenças se mostrava como um dever imposto pela justiça internacional a todos os Estados.

Importante registrar neste esboço de evolução histórica do instituto do reconhecimento da sentença estrangeira que embora a sentença, a princípio, só seja dotada de validade e eficácia no ordenamento jurídico em que foi emitida, e isso não se discute, posto que é de sua essência ser fruto do poder jurisdicional, corolário da soberania do Estado $^{24}$ e, por isso, seu reconhecimento em outros Estados passa a depender naturalmente de critérios por ele estabelecidos, o reconhecimento de sua eficácia deixou de ser visto unicamente como simples gesto de submissão à soberania do Estado prolator da decisão.

As atenções, a partir dessa concepção, voltaram-se à ideia de que o reconhecimento da eficácia da sentença estrangeira, tendo em vista ser ela ato instituidor de direitos e obrigações a influir na esfera subjetiva das partes, passou a se dar com fundamento no interesse de

\footnotetext{
${ }^{22}$ CASTRO, Amílcar de, Das execuções de sentenças estrangeiras no Brasil, cit., p. 53-59; GRECO FILHO, Vicente, Homologação de sentença estrangeira, cit., p. 9; SOUZA, José Ferreira Marnoco e, Execução extraterritorial das sentenças civeis e commerciaes, cit., p. 32 et seq.; VALLADÃO, Haroldo, Direito internacional privado, cit., v. 1, p. 125-127.

${ }^{23}$ SOUZA, José Ferreira Marnoco e, Execução extraterritorial das sentenças civeis e commerciaes, cit., p. 3236.

${ }^{24}$ Inegavelmente a sentença, seja ela nacional ou estrangeira, ostenta natureza de ato de soberania estatal, a ponto de Marcelo Hermes Huck chegar a dizer que "a vinculação entre jurisdição e soberania política e territorial é inata" (Sentença estrangeira e lex mercatoria: horizontes e fronteiras do comércio internacional, cit., p. 32).
} 
segurança jurídica e estabilidade das relações interindividuais entre nacionais e estrangeiros, o que vai ao encontro da própria finalidade do direito internacional privado, qual seja, a proteção dos valores da pessoa humana, buscando solucionar, por meio da formulação de regras e conceitos, os conflitos de leis no espaço, observando sempre os mais puros ideais de justiça e equidade. $^{25}$

Como bem expõe Vicente Greco, "a pessoa humana transcende ao Estado e, quando este normativiza uma conduta, estrutura-se organicamente ou estabelece os procedimentos de realização de direitos, o faz em função daquela" ${ }^{26}$, mostrando-se imprescindível, desse modo, a cooperação entre os Estados na busca pela consecução dos ideais de justiça e plena realização dos valores humanos.

Transportando esses valores ao tema objeto de estudo do presente trabalho, concluímos com Marnoco e Souza que:

“A cooperação dos Estados como órgãos do superorganismo internacional exige que eles contribuam para a administração da justiça no mundo, para a garantia das relações sociais entre os povos e para a realização do direito em todas as manifestações. Ora, isto só se pode conseguir pelo instituto extraterritorial das sentenças que visa a este fim, sancionando a Justiça dos estados estrangeiros." 27

\subsection{Posição sistemática do trabalho}

Como esboçado anteriormente, nasce o direito internacional privado com a admissão pelos Estados da possibilidade de aplicação no foro de uma lei que não a sua. Assim, os mesmos fundamentos que justificam a aceitação da aplicação direta da lei estrangeira também justificam o reconhecimento das sentenças estrangeiras e laudos arbitrais estrangeiros, dandose exequibilidade a decisões judiciais provindas de uma jurisdição alheia e, também, a decisões não judiciais que tenham aplicado uma lei escolhida pelas partes, o que importa, em última análise, na aplicação indireta da lei estrangeira, tendo em vista que, embora o direito

\footnotetext{
${ }^{25}$ GRECO FILHO, Vicente, Homologação de sentença estrangeira, cit., p. 10; VALLADÃO, Haroldo, Direito internacional privado, cit., v. 1, p. 133-134.

${ }^{26}$ GRECO FILHO, Vicente, op. cit., p. 11.

${ }^{27}$ SOUZA, José Ferreira Marnoco e, Execução extraterritorial das sentenças civeis e commerciaes, cit., p. 40.
} 
estrangeiro não se apresente, nesse caso, como norma de conduta abstratamente positivada, aparece como norma já aplicada à hipótese concreta pelo Judiciário doutro Estado. ${ }^{28}$

E, dentre os objetos de estudo do direito internacional privado, se reconhece o estudo da problemática da lei aplicável em decorrência do conflito de lei no espaço e o estudo dos limites da jurisdição internacional, tendo ambos íntima relação com o reconhecimento da sentença e do laudo arbitral estrangeiro, também objeto do direito internacional privado. ${ }^{29}$

Não obstante o objeto do presente estudo ser tema ambivalente, uma vez que atrelado tanto ao direito processual quanto ao direito internacional privado, a presente pesquisa se deu sob o enfoque do direito internacional privado, muito embora não tenha descuidado, como será visto, dos aspectos processuais atrelados ao tema.

Ante ao fato de que o reconhecimento da sentença estrangeira se reveste de uma inequívoca inter-relação entre o direito internacional e o direito processual, já se disse que o estudo voltado ao porquê se reconhece e se dá valor às sentenças estrangeiras interessa mais de perto ao direito internacional, enquanto o estudo voltado ao modo como se reconhece está atrelado ao direito processual.

Como o presente estudo não se volta precipuamente a tratar do modo estabelecido pelo ordenamento jurídico pátrio para se reconhecer a eficácia, em território nacional, de julgados estrangeiros, justifica-se, ainda mais, sua inclusão dentro da área do direito internacional, muito embora, como já dito, trate dos temas processuais indissociáveis às razões que justificam a necessidade de se reconhecer, através do procedimento de homologação, apenas a sentença estrangeira, e não o laudo arbitral estrangeiro.

Por esses motivos, este trabalho encontra-se situado dentro do âmbito do direito internacional privado.

\footnotetext{
${ }^{28}$ Vicente Greco Filho, com base em José Ferreira Marnoco e Souza, ao afirmar que as mesmas razões justificam a aplicação direta e indireta do direito estrangeiro, pondera que: "No primeiro caso, de aplicação direta, invoca-se a disposição de uma lei estrangeira como devendo regular determinada relação jurídica. No segundo caso, de aplicação indireta, já não se invoca uma disposição de lei, mas a sentença que decidiu a questão noutro Estado. O Direito estrangeiro, neste caso, apresenta-se não como disposição geral, mas como norma já aplicada a uma hipótese concreta pelo poder judicial." (Homologação de sentença estrangeira, cit., p. 7).

29 CASTRO, Amílcar de, Das execuções de sentenças estrangeiras no Brasil, cit., p. 33; HUCK, Hermes Marcelo, Sentença estrangeira e lex mercatoria: horizontes e fronteiras do comércio internacional, cit., p. 1.
} 


\subsection{Avocação de jurisdição internacional: ato de soberania na fixação da jurisdição}

Ao Estado, no desempenho de sua finalidade de promover a plena realização dos valores humanos ${ }^{30}$, são atribuídas três funções, por meio das quais é exercido o poder soberano, a administrativa, a legislativa e a jurisdicional.

A jurisdição, enquanto manifestação do exercício de soberania pelo Estado ${ }^{31}$, função de poder, portanto, consiste no poder de declarar e atuar o direito objetivo, que o próprio Estado elaborou ou que outro Estado tenha elaborado, compondo os conflitos de interesses e, dessa forma, resguardando a ordem jurídica e a autoridade das leis. ${ }^{32}$

O exercício dessa função jurisdicional lhe é atribuído pela Constituição, através da função legislativa, que a pressupõe. No exercício desta, o Estado formula as leis, regras gerais e abstratas, por meio das quais, por motivos de conveniência e viabilidade, avoca como seu o poder de dizer o direito em determinadas situações.

O exercício do poder jurisdicional, enquanto função de Estado, sempre esteve vinculado aos seus próprios limites espaciais, de modo que a jurisdição, historicamente, tem sido exercida a partir da concepção de que o poder de dizer o direito é local em sua base, restrito ao território onde é exercida sua soberania, de modo que inata a vinculação entre jurisdição e soberania política e territorial. Oscar Tenório chega a dizer que "a competência internacional é preceito de emanação da soberania do Estado". 33

\footnotetext{
30 “Afirma-se que o objetivo-síntese do Estado contemporâneo é o bem comum e, quando se passa ao estudo da jurisdição, é lícito dizer que a projeção particularizada do bem-comum nessa área é a pacificação com justiça. O Estado Brasileiro quer uma ordem social que tenha como base o primado do trabalho e como objetivo o bem estar e justiça sociais (art. 193) e considera-se responsável pela sua efetividade. Para o cumprimento desse desiderato, propõe-se a desenvolver a sua variada atividade em benefício da população, inclusive intervindo na ordem econômica e na social na medida em que isso seja necessário à consecução do desejado bem-comum, ou bem-estar social (welfare state)." (CINTRA, Antonio Carlos de Araújo; DINAMARCO, Cândido Rangel; GRINOVER, Ada Pellegrini. Teoria geral do processo. 17. ed. São Paulo: Malheiros, 2001. p. 37).

${ }^{31}$ Cintra, Dinamarco e Grinover destacam que a jurisdição, mesmo na política do Estado liberal, extremamente restritiva quanto ao papel interventivo do Estado, sempre esteve incluída como responsabilidade estatal, "uma vez que a eliminação de conflitos concorre, e muito, para a preservação e fortalecimento dos valores humanos da personalidade" (op. cit., p. 37).

${ }^{32}$ SANTOS, Moacyr Amaral. Primeiras linhas de direito processual civil. 22. ed. rev. atual. por Aricê Moacyr Amaral dos Santos. São Paulo: Saraiva, 2002. v. 1, p. 67.

33 TENÓRIO, Oscar Accioly. Lei de Introdução ao Código Civil Brasileiro: Decreto-Lei n. 4.657, de 4 de setembro de 1942. 2. ed. aum. Rio de Janeiro: Borsoi, 1955. p. 380, § 716
} 
Como exercício da soberania do Estado, a jurisdição poderia ser concebida como absoluta e ilimitada. Seria exercida sempre que provocada e em relação a causas de quaisquer naturezas, sendo-lhe mesmo insignificante que os fatos dos quais se origina tenham ou não ocorrido no país, bem assim o domicílio ou a nacionalidade da partes, o objeto da demanda ser um imóvel situado no país ou não, ou mesmo que se encontrem situados no país ou no estrangeiro bens que constituam objeto de inventário.

Não é assim. A despeito de ser manifestação de soberania e, portanto, pleno e completo, o poder jurisdicional não exclui a autolimitação. Moacyr Amaral Santos afirma:

“A concepção de uma jurisdição assim ilimitada, não admitindo fronteiras de
qualquer espécie, esbarra com as jurisdições de outros Estados, daí
resultando conflitos intoleráveis à convivência internacional, por um lado, e,
por outro, o desprestígio daquela função, pela impossibilidade de fazer valer
as decisões de seus juízes no estrangeiro."34

Amílcar de Castro, muito embora entenda que, em razão de sua soberania, cada nação possa livremente definir o alcance de sua jurisdição, estabelecendo, por meio de seu poder legislativo autônomo, quais causas devem ou não serem submetidas à sua jurisdição, afirma que regras assim, além de inúteis, seriam "inútil ameaça ou vã exibição de força". ${ }^{35}$

Há, portanto, limitações internacionais ditadas pela necessidade de convivência internacional entre os Estados, de modo que somente algumas causas lhes interessam julgar, incumbindo ao legislador definir os elementos ou pontos de conexão que, presentes, determinam que a causa se enquadre dentre as submetidas ao poder jurisdicional do Estado.

Segundo Vicente Greco Filho, os critérios definidores desses pontos de conexão são a viabilidade, entendida como efetividade, e a conveniência ${ }^{36}$. A efetividade, vista como a possibilidade real do poder jurisdicional incidir no patrimônio material ou espiritual das pessoas, e a conveniência de que a realização desse poder jurisdicional venha a se estender a determinado território, abrangendo certas relações jurídicas. ${ }^{37}$

\footnotetext{
${ }^{34}$ SANTOS, Moacyr Amaral, Primeiras linhas de direito processual civil, cit., v. 1, p. 199.

${ }^{35}$ CASTRO, Amílcar de, Direito internacional privado, cit., p. 531 a 537.

${ }^{36}$ GRECO FILHO, Vicente, Homologação de sentença estrangeira, cit., p. 64.

${ }^{37}$ GRECO FILHO, Vicente, op. cit., p. 64; HUCK, Hermes Marcelo, Sentença estrangeira e lex mercatoria: horizontes e fronteiras do comércio internacional, cit., p. 5.
} 
Em vista desses critérios, técnicos ou políticos, utilizados pelo legislador na escolha dos pontos de conexão, Hermes Marcelo Huck, com supedâneo em Charles N. Fragistas, identifica alguns pontos de conexão. São eles: i) nacionalidade do autor ou do réu; ii) domicílio do réu; iii) foros especiais fundados em circunstâncias relativas ao objeto do litígio e suas vinculações substanciais com o território onde se desenrola o processo; iv) foros especiais fundados na conexão de um litígio com outro pendente em tribunal localizado no mesmo território; v) foro do lugar da situação dos bens do réu; e, vi) presença pessoal do devedor. $^{38}$

Nesse sentido, Vicente Greco Filho pondera:

\begin{abstract}
"Não ocorre que a jurisdição mude de natureza, seja a causa exclusivamente composta de elementos nacionais ou estrangeiros ou de ambos, mas simplesmente que somente algumas interessam a nosso país julgar em virtude dos critérios acima referidos, os quais se concretizam através da escolha, pela Lei, de elementos ou pontos de conexão que, presentes, determinam a competência do poder judiciário nacional." 39
\end{abstract}

Pode-se dizer, assim, que esses elementos ou pontos de conexão que atraem o exercício da jurisdição de um Estado determinam os limites dessa jurisdição, posto que não há sentido que o legislador nacional a estenda além de fronteiras inacessíveis.

A conveniência política dessa limitação tem como pressuposto lógico a aceitação de que há causas que devem ser submetidas ao poder jurisdicional de Estado portador de soberania igualmente digna. Em outras palavras, o ato de limitar sua jurisdição decorre da admissão de que a outro poder jurisdicional devam ser submetidas determinadas demandas, cujo pressuposto lógico é a aceitação de que há outras soberanias tão dignas quanto a sua, pois caso assim não fosse, avocaria com exclusividade o poder jurisdicional em relação a todas as causas que pudessem porventura lhe interessar. Se limita a sua jurisdição é porque reconhece como legítimo o poder jurisdicional exercido por outros Estados igualmente soberanos. ${ }^{40}$

Ao limitar a extensão da sua jurisdição, o Estado reconhece que a outros Estados deva ser submetida a composição de determinadas lides. E se assim o faz, é porque reconhece

\footnotetext{
${ }^{38}$ FRAGISTAS, Charles N. La competénce internationale en droit privé. Recueil des Cours, v. 104, n. 3, p. 197 et seq., 1961, apud HUCK, Hermes Marcelo, Sentença estrangeira e lex mercatoria: horizontes e fronteiras do comércio internacional, cit., p. 8.

${ }^{39}$ GRECO FILHO, Vicente, Homologação de sentença estrangeira, cit., p. 64-65.

${ }^{40}$ Ibidem, p. 89.
} 
como igualmente legítimo o poder jurisdicional desse outro Estado, cujos provimentos jurisdicionais haverão de ser tão eficazes quanto os seus, o que implica, em última análise, reconhecer na sentença estrangeira uma verdadeira sentença ${ }^{41}$. Hermes Marcelo Huck $^{42}$ afirma que no reconhecimento da pluralidade de soberanias igualmente dignas reside a razão de ser do direito internacional privado.

Afigura-se, portanto, como interesse da nação, vista como Estado, limitar sua jurisdição. É uma limitação que estabelece as linhas divisórias da jurisdição do Estado em face da jurisdição de outros Estados, delimitando consequentemente sua competência geral, internacional, dita também externa. ${ }^{43}$

Cumpre, desde já, como advertido por Liebman, estabelecer que, a rigor, a problemática da competência internacional não é precisamente um problema de competência. É antes, porém e mais precisamente, uma questão de limite da extensão da jurisdição de um Estado em face da jurisdição de outros Estados igualmente soberanos. ${ }^{44}$

Isso, de acordo com Hélio Tornaghi, pressupõe um conflito, ao menos possível, entre jurisdições de diferentes Estados, tendo em vista afirmar que a "competência internacional é a que é atribuída à justiça de um Estado em casos nos quais também se justificaria a intervenção do Poder Judiciário de outro Estado". ${ }^{4}$

Nos dizeres de Liebman, a lei nacional pode fazer "uma determinação direta da extensão da jurisdição do próprio país, dispondo expressamente quais são as causas a ela sujeitas, excluindo, portanto, implicitamente, todas as outras". ${ }^{4}$

\footnotetext{
${ }^{41}$ GRECO FILHO, Vicente, Homologação de sentença estrangeira, cit., p. 88-90.

${ }^{42}$ HUCK, Hermes Marcelo, Sentença estrangeira e lex mercatória: horizontes e fronteiras do comércio internacional, cit., p. 28.

${ }^{43}$ CASTRO, Amílcar de, Direito internacional privado, cit., p. 528-529.

${ }^{44}$ LIEBMAN, Enrico Tullio. Os limites da jurisdição brasileira. In: __. Estudos sobre o processo civil brasileiro. São Paulo: Saraiva, 1947. p. 18. José Ignácio Botelho de Mesquita, comungando no mesmo entendimento, pondera: "Com efeito, as normas que definem a competência internacional não se restringem a uma simples atribuição de atividade jurisdicional entre os diversos órgãos investidos de uma mesma jurisdição, mas, ao contrário, determinam a extensão de uma jurisdição (a nacional) diante das demais (as de outros Estados soberanos)." (Da competência internacional e dos princípios que a informam. Revista de Processo, São Paulo, Revista dos Tribunais, v. 13, n. 50, p. 51, abr./jun. 1988).

${ }^{45}$ TORNAGHI, Hélio. Comentários ao Código de Processo Civil. São Paulo: Revista dos Tribunais, 1974. v. 1, p. 302.

${ }^{46}$ LIEBMAN, Enrico Tullio, op. cit., p. 23.
} 
Esclarece ainda o processualista italiano que a norma de competência interna não fornece "título de submissão da controvérsia à jurisdição brasileira, mas, ao contrário, o pressupõe", acrescentando ainda que a norma de competência territorial interna "não é suficiente para tornar uma causa sujeita à jurisdição brasileira, se a ela já não estiver submetida por outros motivos". 47

Há, portanto, uma relação de precedência lógica das regras de competência internacional sobre as de competência interna, sendo que, de acordo com Celso Agrícola $\mathrm{Barbi}^{48}$, deve o juiz, na análise sobre se detém ou não competência para a causa, verificar se a causa se insere dentro dos limites que fixam a extensão da jurisdição nacional, para, só então, aferir se ela se encontra dentro das que, por força das regras de competência interna, lhe estariam submetidas.

Por oportuno, e muito bem anotado por Maristela Basso, a relação de precedência lógica aí estabelecida "aparece ainda como pressuposto para aplicação das normas de direito internacional privado, cujo escopo é indicar o direito material aplicável às relações jurídicas contendo elemento estrangeiro". 49

Assim, anteriormente à análise da distribuição interna de competência, há que se perquirir a respeito da existência de um pressuposto, qual seja o de aferir se o Estado avocou para si, por meio de suas normas internas, a jurisdição para o exame da causa.

Por essa razão, pondera com clareza José Ignácio Botelho de Mesquita:

“[...] sobre as causas não incluídas na competência internacional do Brasil, o que faltará ao juiz ou tribunal brasileiros não será meramente competência no sentido usual da palavra, mas, sim, jurisdição, no sentido de poder jurisdicional. A decisão que o juiz em tais casos proferir, será decisão proferida por órgão não investido de jurisdição, como se daria no caso de ter sido proferida por um tabelião ou oficial de cartório; incluir-se-ia na categoria das sentenças inexistentes." ${ }^{50}$

\footnotetext{
${ }^{47}$ LIEBMAN, Enrico Tullio, Os limites da jurisdição brasileira, cit., p. 22.

${ }^{48}$ BARBI, Celso Agrícola. Comentários ao Codigo de Processo Civil: Lei n 5.869, de 11 de janeiro de 1973. Rio de Janeiro: Forense, 1975 v. 1, t. 2, p. 396. Ver: MESQUITA, José Ignácio Botelho de, Da competência internacional e dos princípios que a informam, cit., p. 53.

${ }^{49}$ BASSO, Maristela. Curso de direito internacional privado. 2. ed. rev. e atual. conforme a Lei n. 12.376/2010. São Paulo: Atlas, 2011. p. 266.

${ }^{50}$ MESQUITA, José Ignácio Botelho de, op. cit., p. 52-53.
} 
Acrescenta ainda:

\begin{abstract}
"Pela mesma razão, será insusceptível de homologação no Brasil a sentença estrangeira pronunciada em matéria que a lei brasileira reputa de competência exclusiva das autoridades judiciárias brasileiras; é caso em que o Brasil não reconhece o poder dos juízes e tribunais de outros Estados de exercer jurisdição sobre tais causas." ${ }^{11}$
\end{abstract}

Esclarecida a relação de precedência lógica das normas que delimitam a extensão da jurisdição nacional sobre as regras de competência interna, convém, diante do grande número de inexatidões terminológicas ocorridas entre jurisdição e competência, estabelecer que, de acordo com Couture, "la competencia es la potestad de jurisdición para una parte del sector jurídico: aquel especificamente asignado al conocimiento de determinado órgano jurisdicional. En todo aquello que no le ha sido atribuido, um juez, aunque sigue teniendo jurisdicción, es incompetente". 52

Portanto, como dito, a jurisdição consiste no poder de declarar e atuar o direito objetivo, que o próprio Estado elaborou ou que outro Estado tenha elaborado, compondo os conflitos de interesses e, dessa forma, resguardando a ordem jurídica e a autoridade das leis, enquanto a competência, por sua vez, consiste no poder de fazer atuar a parcela de jurisdição que tem um órgão jurisdicional diante de um caso concreto. ${ }^{53}$

Diante dessa distinção, bem como em razão da relação de precedência lógica das normas que delimitam a extensão da jurisdição nacional sobre as regras de competência interna, figurando aquelas como condicionantes destas últimas, o Código de Processo Civil vigente deu precedência às normas de competência internacional, em detrimento das normas de competência interna, conforme se nota no Livro I, Título IV, Capítulo II do Código de Processo Civil vigente.

Agiu bem o legislador de 1973. O Código de Processo Civil de 1939, assim como os Códigos Processuais dos Estados, antes da unificação ocorrida com o Código de 1939 eram também omissos sobre as regras que determinavam o alcance da jurisdição, o que ocorria

\footnotetext{
${ }^{51}$ MESQUITA, José Ignácio Botelho de, Da competência internacional e dos princípios que a informam, cit., p. 53.

${ }^{52}$ COUTURE, Eduardo. Fundamentos del derecho procesal civil. 3. ed. Buenos Aires: Roque Depalma, 1958. p. 29. GRECO FILHO, Vicente, Homologação de sentença estrangeira, cit., p. 63.

${ }^{53}$ GRECO FILHO, Vicente, op. cit., p. 63.
} 
também no Regulamento n. $737^{54}$. Vicente Greco Filho, ao abordar o tema, afirma que o Código de Processo anterior "não tratava especificamente do assunto, de forma que a doutrina, diante da falta de sistematização, procurava encontrar nas regras de competência interna, implícita, a competência internacional, disciplinada expressamente no art. 12 da Lei de Introdução ao Civil". 55

O método até então utilizado era o de determinação indireta, segundo o qual não havia disposições expressas sobre o tema. Consequente, e necessariamente, os limites da jurisdição eram deduzidos mediatamente dos dispositivos legais sobre a competência territorial de cada um dos órgãos judiciários internos, ao passo que no método ora utilizado (o de determinação direta), a lei dispõe expressamente quais as causas submetidas à jurisdição do Estado, excluindo, implicitamente, as demais. ${ }^{56}$

Vicente Greco Filho afirma que o Brasil, por ter estabelecido normas especiais para a competência internacional, consubstanciadas nos artigos 88 e 89 do Código de Processo Civil, seguiu, observada a classificação de sistemas de regulamentação da competência internacional proposta por Charles N. Fragistas, o sistema latino que "consiste na regulamentação específica da competência internacional, através de critérios próprios, que podem ser distintos dos critérios de determinação da competência interna". ${ }^{57}$

Parece-nos, portanto, salvo alguns tratados internacionais que procuram unificar os critérios determinadores da competência internacional, os quais, se ratificados, incorporam-se ao direito interno, que os limites da extensão da jurisdição de um Estado não podem ser determinados senão por um ato de soberania.

\footnotetext{
${ }^{54}$ DINAMARCO, Cândido Rangel. Direito processual civil. São Paulo: José Bushatsky, 1975. p. 104.

${ }_{55}^{5}$ GRECO FILHO, Vicente, Homologação de sentença estrangeira, cit., p. 65.

${ }^{56}$ Por todos: LIEBMAN, Enrico Tullio, Os limites da jurisdição brasileira, cit., p. 22-24.

${ }^{57}$ Vicente Greco Filho informa que o autor francês propõe a sistematização em quatro grandes grupos: o sistema latino, já especificado, o "2) Sistema germânico, segundo o qual a competência judicial internacional decorre da soma de todas as competências territoriais internas; 3) Sistema anglo-americano, cuja característica primordial é a possibilidade de que seja exercido poder físico sobre o réu, isto é, haveria competência internacional quando fosse possível a citação do demandado no território do Estado; 4) Sistema Suíço, cuja característica principal é a proteção constitucional à pessoa que, sendo solvente, tenha domicílio na Suíça, tornando exclusiva a competência no caso de réu domiciliado no país" (Homologação de sentença estrangeira, cit., p. 66).
} 


\subsubsection{Competência internacional}

O tema da competência internacional do juiz brasileiro tem fundamental importância, na medida que a admissão da jurisdição do juiz estrangeiro pelo ordenamento jurídico nacional (lex fori), afigura-se como condição de reconhecimento da sentença estrangeira, conforme se extrai da regra inserta no artigo 15 da Lei de Introdução às Normas do Direito Brasileiro.

Dentre os requisitos estabelecidos por esse artigo para que seja reconhecida no Brasil a sentença proferida por juiz estrangeiro, encontra-se o fato de ter sido proferida por um juiz competente.

Trata-se, portanto, da competência do juiz estrangeiro estabelecida conforme as regras do Estado em que se buscará o reconhecimento da sentença forasteira. Podemos daí extrair a conclusão, que será melhor abordada mais à frente, de que somente serão reconhecidas as sentenças proferidas em outros Estados se a parcela de jurisdição exclusiva do juiz brasileiro não houver sido invadida pela demanda proposta e decidida no Estado estrangeiro. Afasta-se, nesses casos, qualquer possibilidade de conflito de competência.

Na medida que a autoridade judiciária brasileira detém jurisdição exclusiva para julgar a demanda conforme suas próprias regras, está automaticamente descartada a possibilidade de ser reconhecida a sentença proferida por Estado estrangeiro, ainda que, de acordo com suas regras, detenha jurisdição para a causa.

Esse entendimento vem também consagrado no artigo 314 do Código Bustamante:

"Art. 314 - A lei de cada Estado contractante determina a competencia dos tribunaes, assim como a sua organização, as formas de processo e a execução das sentenças e os recursos contra suas decisões." ${ }^{\text {58 }}$

Dito isso, e a despeito da discussão travada a respeito da revogação ou não do artigo 12 da Lei de Introdução às Normas do Direito Brasileiro, fato é que as regras que determinam

\footnotetext{
${ }^{58}$ Conhecida internacionalmente como Código Bustamante, a Convenção Internacional de Direito Privado, firmada em 18 de fevereiro de 1928, na cidade de Havana, em Cuba, definiu as bases para um código de direito internacional privado. Em seu Título X trata das sentenças proferidas por tribunais estrangeiros, consagrando o princípio de que a sentença proferida em um dos Estados contratantes terá força executória nos demais. Ele foi promulgado no Brasil pelo Decreto n. 18.871, de 13 de agosto de 1929.
} 
a extensão da jurisdição do juiz brasileiro estão insculpidas nos artigos 88 e 89 do Código de Processo Civil vigente.

Cumpre, desde já, observar que essas normas têm duplo alcance, de modo que analisaremos, brevemente, neste momento, o seu alcance nos planos interno e internacional.

Basicamente, pode-se dizer que no plano interno os pontos de contacto previstos nessas normas determinam as causas submetidas à jurisdição nacional, enquanto, por outro lado, no plano internacional determinam o alcance da jurisdição estrangeira em face da jurisdição nacional, ou seja, "o que se admite e o que não se admite que os juízes estrangeiros decidam". 59

Não se está aqui dizendo que no plano internacional as normas que estabelecem os limites da jurisdição brasileira disciplinam as causas que devem ou não estar submetidas à jurisdição das autoridades judiciárias estrangeiras, na medida que essa limitação apenas pode ser estabelecida pelas leis dos Estados a que essas autoridades judiciárias pertençam. Isso porque a cada Estado incumbe regular internamente a competência de seus órgãos e de seus poderes, seja de direito material, seja de direito processual. Em outras palavras, o alcance da jurisdição dos tribunais brasileiros dependerá da lei brasileira e a dos tribunais estrangeiros da lei estrangeira ${ }^{60}$. Nesses casos, o que ocorre, e muito importante, é que se estabelece um pressuposto de homologabilidade no Brasil, de acordo com sua lex processualis, das sentenças proferidas por esses tribunais estrangeiros.

Portanto, como já brevemente abordado, imperioso se mostra, para que a sentença estrangeira possa ser homologada pelo Superior Tribunal de Justiça, que a autoridade judiciária estrangeira que a tenha proferido não invada a parcela de jurisdição exclusiva das autoridades judiciárias brasileiras. Em outras palavras, é necessário que o Brasil admita, na hipótese, a jurisdição da autoridade judiciária estrangeira, conforme requisito inafastável estabelecido no artigo 15 da Lei de Introdução às Normas do Direito Brasileiro.

Em síntese, dessa dupla perspectiva notamos que esses dois artigos delimitam as causas que se encontram abarcadas pela jurisdição brasileira (todas as previstas nesses dois

\footnotetext{
${ }^{59}$ MESQUITA, José Ignácio Botelho de, Da competência internacional e dos princípios que a informam, cit., p. 59.

${ }^{60}$ Haroldo Valladão esclarece: "A lei geral do processo, a que resolve os conflitos de leis processuais, a lex processualis, é a lex fori, a lei do foro, do tribunal ou juízo no qual se desenvolve o processo." (Direito internacional privado. Rio de Janeiro: Freitas Bastos, 1978. v. 3, p. 123).
} 
artigos) e, por outro lado, estabelecem os limites da extensão da jurisdição de outros Estados para efeito de serem homologadas no Brasil as sentenças por eles proferidas. Em outras palavras, nesse último caso, determinam as causas em que não se admite o exercício da jurisdição estrangeira.

Nada obstante, a princípio, partindo da premissa adotada por Jose Ignácio Botelho de Mesquita de que a jurisdição é uma atividade onerosa para o Estado, e que, portanto, não deve ser exercida desnecessariamente, parece-nos coerente o entendimento de que as causas não incluídas dentre as elencadas nos artigos 88 e 89 do Código de Processo Civil estão excluídas da jurisdição brasileira ${ }^{61}$, pelo simples fato de não nos interessar, nesses casos, o exercício da jurisdição. Disso, extraímos a consequência imediata de que, com relação às causas não incluídas nesses artigos, são exclusivamente competentes as autoridades judiciárias estrangeiras, podendo, nessas hipóteses, observados os demais requisitos, a sentença ser homologada no Brasil. ${ }^{62}$

Quando da entrada em vigor do Código de Processo Civil em 1974, muito se discutiu a respeito, se os artigos 88 e 89 teriam revogado tácita e parcialmente o artigo 12 da Lei de Introdução ao Código Civil (atual Lei de Introdução às Normas do Direito Brasileiro), que dispõe:

“Art. 12 - É competente a autoridade judiciária brasileira, quando for o réu domiciliado no Brasil ou aqui tiver de ser cumprida a obrigação.

$\S 1^{\circ}$ - Só à autoridade judiciária brasileira compete conhecer das ações relativas a imóveis situados no Brasil.

\footnotetext{
${ }^{61}$ Ressalvamos a hipótese prevista no artigo $7^{\circ}$ do Código Penal, que determina: “Art. $7^{\circ}$ - Ficam sujeitos à lei brasileira, embora cometidos no estrangeiro: I - os crimes: a) contra a vida ou a liberdade do Presidente da República; b) contra o patrimônio ou a fé pública da União, do Distrito Federal, de Estado, de Território, de Município, de empresa pública, sociedade de economia mista, autarquia ou fundação instituída pelo Poder Público; c) contra a administração pública, por quem está a seu serviço; d) de genocídio, quando o agente for brasileiro ou domiciliado no Brasil; II - os crimes: a) que, por tratado ou convenção, o Brasil se obrigou a reprimir; b) praticados por brasileiro; c) praticados em aeronaves ou embarcações brasileiras, mercantes ou de propriedade privada, quando em território estrangeiro e aí não sejam julgados. $\S 1^{\circ}$ - Nos casos do inciso I, o agente é punido segundo a lei brasileira, ainda que absolvido ou condenado no estrangeiro. $\S 2^{\circ}$ - Nos casos do inciso II, a aplicação da lei brasileira depende do concurso das seguintes condições: a) entrar o agente no território nacional; b) ser o fato punível também no país em que foi praticado; c) estar o crime incluído entre aqueles pelos quais a lei brasileira autoriza a extradição; d) não ter sido o agente absolvido no estrangeiro ou não ter aí cumprido a pena; e) não ter sido o agente perdoado no estrangeiro ou, por outro motivo, não estar extinta a punibilidade, segundo a lei mais favorável. $\S 3^{\circ}$ - A lei brasileira aplica-se também ao crime cometido por estrangeiro contra brasileiro fora do Brasil, se, reunidas as condições previstas no parágrafo anterior: a) não foi pedida ou foi negada a extradição; b) houve requisição do Ministro da Justiça."

${ }^{62}$ MESQUITA, José Ignácio Botelho de, Da competência internacional e dos princípios que a informam, cit., p. 54.
} 
$\$ 2^{\circ}$ - A autoridade judiciária brasileira cumprirá, concedido o exequatur e segundo a forma estabelecida pela lei brasileira, as diligências deprecadas por autoridade estrangeira competente, observada a lei desta, quanto ao objeto das diligências."

Essa norma, portanto, como se nota, contém as hipóteses em que a autoridade judiciária brasileira detém jurisdição, tanto para exercê-la nos tribunais domésticos, como também para o cumprimento de cartas rogatórias.

Com exceção ao cumprimento de cartas rogatórias previsto em seu parágrafo $2^{\circ}$, podemos dizer que esse artigo, em seu caput, submete à jurisdição da autoridade judiciária brasileira: i) ação ajuizada contra réu domiciliado no Brasil e ii) litígio versando sobre obrigação a ser cumprida no Brasil, sem, no entanto, excluir essas causas da apreciação de jurisdições de outros Estados. Por outro lado, no parágrafo $1^{\circ}$ avoca como sua a autoridade jurisdicional para conhecer das ações relativas a imóveis situados no Brasil. Trata da jurisdição exclusiva da autoridade judiciária brasileira, na medida que exclui a hipótese, ali prevista, da sujeição à jurisdição de Estado estrangeiro.

Muito embora tenha ele surgido em resposta "ao debate originalmente formulado na vigência da Introdução ao Código Civil de 1916, que estabelecia em seu art. 15, que a competência, forma de processo e os meios de defesa seriam disciplinados pela lei do lugar em que a ação fosse ajuizada"63, não nos parece sem razão os que advogam a tese de que os artigos 88 e 89 do Código de Processo Civil o tenham revogado de forma tácita, ainda que parcialmente. $^{64}$

Afirmam esses doutrinadores que os referidos artigos do Código de Processo teriam tratado por completo da matéria constante no caput e no parágrafo $1^{\circ}$, restando em vigor

\footnotetext{
${ }^{63}$ BASSO, Maristela, Curso de direito internacional privado, cit., p. 266.

${ }^{64}$ GRECO FILHO, Vicente, Homologação de sentença estrangeira, cit., p. 67-68; HUCK, Hermes Marcelo, Sentença estrangeira e lex mercatoria: horizontes e fronteiras do comércio internacional, cit., p. 9-10; MESQUITA, José Ignácio Botelho de, Da competência internacional e dos princípios que a informam, cit., p. 51 et seq. Muito embora Maristela Basso explique que a técnica implícita nas regras contidas no artigo 12 se circunscreva à aplicação da lex fori e não afirme ter ocorrido a revogação tácita, não nos parece que se oponha a tal tese, na medida que diz, ao estabelecer a regra de precedência lógica existente entre as regras que delimitam a extensão da jurisdição brasileira e as de competência interna, que "como o art. 12 da Lei de Introdução às Normas do Direito Brasileiro indica a competência internacional, deve o juiz nacional analisar em duas etapas o que lhe é submetido: em um primeiro momento, ele observa os limites espaciais da jurisdição brasileira, como nas competências concorrente e exclusiva, respectivamente endereçadas pelos arts. 88 e 89 do Código de Processo Civil, e em seguida procede à análise da competência interna, que será medida pelas normas de organização judiciária do direito processual brasileiro" (op. cit., p. 266).
} 
apenas o parágrafo $2^{\circ}$, tendo em vista, com relação a este último, não ter havido revogação expressa, tampouco tratamento novo que determinasse a revogação tácita.

Com lastro no artigo 12 da Lei de Introdução às Normas do Direito Brasileiro, o artigo 88 do Código de Processo não só abarca as hipóteses em que o réu for domiciliado no Brasil, ou quando aqui deva ser cumprida a obrigação, como também estende a jurisdição brasileira às ações originadas de fato ou ato ocorrido no Brasil, objetivando alcançar também as obrigações decorrentes de ato ilícito. O artigo 89, que trata da competência exclusiva, não só a estende às ações relativas a imóveis situados no Brasil, como também avoca a jurisdição para proceder a inventário e partilha de bens situados no Brasil, ainda que o autor da herança seja estrangeiro e tenha residido fora do território nacional.

Diz-se, portanto, a respeito desses dispositivos (incs. III do art. 88 e II do art. 89) que ampliaram os limites da jurisdição brasileira.

Cabe, neste momento, tecer alguns comentários a respeito das hipóteses que o legislador pátrio entendeu por conveniente avocá-las à sua jurisdição, e que se encontram elencadas nos referidos artigos 88 e 89 do Código de Processo Civil.

Iniciaremos pelo artigo 89, que estabelece os limites da jurisdição brasileira nos seguintes termos:

“Art. 89 - Compete à autoridade judiciária brasileira, com exclusão de qualquer outra:

I - conhecer das ações relativas a imóveis situados no Brasil;

II - proceder a inventário e partilha de bens, situados no Brasil, ainda que o autor da herança seja estrangeiro e tenha residido fora do território nacional."

O conteúdo do inciso I refere-se a um caráter excepcional da jurisdição da autoridade judiciária brasileira, qual seja o de afastar o reconhecimento de qualquer outra jurisdição que não a doméstica, que já vinha previsto no artigo 12 da Lei de Introdução às Normas do Direito Brasileiro.

A situação do imóvel, portanto, determinará a exclusividade da jurisdição nacional, em detrimento de qualquer outra. Nota-se que nesse caso aplica-se totalmente o princípio da 
territorialidade, na medida que a situação do imóvel também impõe a aplicação da lei nacional, conforme previsto no artigo $8^{\circ}$ da Lei de Introdução às Normas do Direito Brasileiro.

Vicente Greco observa que a vis atractiva do imóvel é de tal maneira significativa que determina a exclusividade da jurisdição brasileira, não apenas para as ações reais, como também para as ações pessoais ou obrigacionais a ele relacionadas, de modo que para o autor não haveria,"portanto, necessidade de discussão sobre a natureza real ou pessoal da ação; basta que seja relativa a imóvel para que fixe a competência nacional". ${ }^{65}$

Trata-se, como bem pondera Maristela Basso ${ }^{66}$, de aplicação da regra forum rei sitce, segundo a qual "em certos limites, a jurisdição normal sobre litígios envolvendo casos com conexão internacional é afastada quando o objeto da lide versar sobre bens imóveis e relações a ele concernentes". Ainda segundo a professora da Faculdade de Direito da Universidade de São Paulo, essa regra se consagrou como norma consuetudinária internacional, sendo, aos poucos, positivada pelos legisladores nacionais.

Disposição semelhante encontra-se no artigo $325^{67}$ do Código Bustamante. Como se depreende da leitura do dispositivo, a competência do juiz do local do imóvel refere-se não somente às ações reais sobre bens imóveis, mas também às ações mistas de limite de divisão de bens, como são os casos envolvendo processos de partilha. Ainda o artigo 326 do Código Bustamante corrobora o disposto nos artigos 89 , I, e 12 , parágrafo $1^{\circ}$, da Lei de Introdução às Normas do Direito Brasileiro, tendo em vista que se refere à competência do juiz de um dos Estados contratantes para julgar ação envolvendo bens localizados em seu território como exclusiva. $^{68}$

A inovação, entretanto, tomando como base o artigo 12 da Lei de Introdução às Normas do Direito Brasileiro, é o inciso II, que amplia os limites da jurisdição nacional, com

\footnotetext{
${ }^{65}$ GRECO FILHO, Vicente, Homologação de sentença estrangeira, cit., p. 73.

66 BASSO, Maristela, Curso de direito internacional privado, cit., p. 269. Miguel Maria de Serpa Lopes acrescenta: "A regra da competência territorial, no concernente às ações imobiliárias, constitui atualmente um princípio de Direito Consuetudinário Internacional." (Comentários à Lei de Introdução ao Código Civil. 2. ed. rev. e aum. Rio de Janeiro: Freitas Bastos, 1959. v. 3, p. 120).

67 "Art. 325 - Para o exercicio de acções reaes sobre bens immoveis e para o das acções mixtas de limites e divisão de bens communs, será juiz competente o da situação dos bens."

68 "Art. 326 - Se, nos casos a que se referem os dois artigos anteriores, houver bens situados em mais de um Estado contractante, poderá recorrer-se aos juizes de qualquer delles, salvo se a lei da situação, no referente a immoveis, o prohibir."
} 
exclusão de qualquer outra, para proceder a inventário e partilha de bens situados no Brasil, ainda que o autor da herança seja estrangeiro e tenha residido fora do território nacional.

Ao que parece, a inclusão desse inciso dentre as hipóteses em que a jurisdição brasileira é exercida de forma exclusiva encerrou divergência doutrinária e jurisprudencial havida com relação ao princípio da universalidade sucessória, adotado no artigo 10 da Lei de Introdução às Normas do Direito Brasileiro, nos casos de inventário e partilha de bens localizados em território brasileiro de autor da herança domiciliado no exterior, sendo que lá se tenha processado o inventário e partilha.

Na medida que esse princípio prega a adoção de uma lei e um único processo para todo o processo sucessório, a hesitação doutrinária e jurisprudencial residia no local em que seria processado o inventário, nas hipóteses em que houvesse bens a inventariar no Brasil e no exterior.

A inclusão desse inciso impôs nítida restrição ao princípio da universalidade sucessória. A disciplina legal deixa claro que o "imóvel situado no Brasil decreta a cisão do inventário, de forma que será perfeitamente possível (aliás será indispensável), a ocorrência de dois inventários, um no exterior e outro no Brasil para os bens aqui situados". ${ }^{69}$

Note que na hipótese de ocorrência de dois inventários, a territorialidade do inventário de bem imóvel aqui situado poderá acarretar a aplicação de leis diferentes à sucessão, na medida que, independentemente da lei material aplicável pela autoridade judiciária estrangeira, o juiz nacional obedecerá ao quanto disposto no artigo 10 da Lei de Introdução às Normas do Direito Brasileiro, que determina que a sucessão por morte reger-se-á pela lei do país em que era domiciliado o de cujus.

Isso se deve ao fato do artigo 89, I, do Código de Processo ser regra de limite de extensão de jurisdição apta a resolver conflitos de competência, e não regra de aplicação de lei material, de modo que não revogou o referido artigo $10 .^{70}$

\footnotetext{
${ }^{69}$ GRECO FILHO, Vicente, Homologação de sentença estrangeira, cit., p. 73. O autor afirma que o Supremo Tribunal Federal, antes da vigência do novo Código de Processo Civil, havia optado por solução contrária à estabelecida, ou seja, pela unicidade do juízo do inventário e da lei da sucessão (Ibidem, mesma página).

${ }^{70}$ GRECO FILHO, Vicente, op. cit., p. 74.
} 
Caso o autor da herança não tenha deixado bens localizados no Brasil e tampouco houver ponto de contacto que atraia a aplicação do artigo 88 do Código de Processo Civil, não se realizará no Brasil inventário, por incompetência absoluta da autoridade judiciária brasileira. Nota-se aqui a presença do critério da efetividade que permeia a mente do legislador no momento da escolha dos elementos que delimitam a extensão da jurisdição, de que já tratamos, na medida que nenhum sentido teria uma sentença de partilha no Brasil que não pudesse ser executada no exterior.

Conclusão que também nos parece relevante é que a sentença de partilha do inventário realizado no exterior não será reconhecida no Brasil com relação aos bens aqui existentes. Note, por oportuno, que a lei não faz distinção entre serem móvel ou imóvel os bens a inventariar, obrigando-se, consequentemente, pelo fato de não ser reconhecida no Brasil a referida sentença, a proceder a novo inventário e nova partilha, nas hipóteses em que domiciliado no exterior o autor da herança e lá processado o inventário de bens aqui situados.

O Supremo Tribunal Federal, enquanto órgão judiciário competente para conhecer dos processos de homologação de sentenças estrangeiras, teve curiosa evolução no tocante à interpretação e aplicação desse inciso II do artigo 89.

Após a entrada em vigor do dispositivo, o Supremo Tribunal se mostrou unânime em negar homologação, para execução em território nacional, às sentenças estrangeiras que tinham por objeto partilha de bens situados em território nacional, decorrentes de processos de sucessão causa mortis. ${ }^{71}$

Tal fato não ocorreu, contudo, quanto às sentenças, na maioria das vezes decorrentes de casos de divórcio processados no exterior, que contivessem também, como objeto, partilha de bens aqui situados. Num primeiro momento, estendeu-se analogicamente à partilha inter vivos de bens localizados em território nacional a interpretação dada ao dispositivo, entendido como de ordem pública, de modo que o Supremo Tribunal Federal se negou, por um período, a homologar sentenças estrangeiras de divórcio, quando houvesse partilha de bens aqui situados.

\footnotetext{
${ }^{71}$ STF - SEC n. 3.348, rel. Min. Cordeiro Guerra, j. 11.04.1984. Também as decisões: SE n. 3.780, República Federal da Alemanha, DJU, de 22.05.1987, p. 9.753; SE n. 4.013, Estados Unidos da América, RTJ 125/507, 1988 (HUCK, Hermes Marcelo, Sentença estrangeira e lex mercatoria: horizontes e fronteiras do comércio internacional, cit., p. 16).
} 
No julgamento da Sentença Estrangeira n. 2.709, dos Estados Unidos da América ${ }^{72}$, encontramos na fundamentação do então Ministro Antonio Neder a postura adotada no Supremo Tribunal Federal de negar homologação à sentença de partilha inter vivos de bens situados no Brasil. O ministro alegou que a sentença estrangeira que havia aprovado a partilha de bens do casal, dentre eles incluindo um imóvel localizado em território nacional, ofendia à ordem pública brasileira, na medida que o artigo 89, inciso II, de que ora tratamos, dentre outros dispositivos legais citados na decisão, expressam que a partilha de bens realizada inter vivos, em decorrência da separação judicial dos cônjuges ou do divórcio, deveria ser processada na jurisdição do Brasil.

Curioso notar que no julgado em análise o ministro faz menção apenas ao inciso II do artigo 89 do Código de Processo Civil, muito embora a sentença que se pretendia homologar partilhasse bem imóvel localizado em território nacional. Desse modo, a nosso ver, além do retrógado e desnecessário entendimento de negar homologação à sentença de divórcio que continha partilha de bem imóvel aqui localizado, tendo em vista que a lei a essa hipótese não impunha a exclusividade da jurisdição brasileira, a decisão mostra-se equivocada em sua fundamentação legal, na medida que a ofensa à ordem pública ocorreria pela não observância do inciso I do mesmo artigo.

Nada obstante, fato é que o Supremo Tribunal Federal alterou seu entendimento e passou a homologar sentenças estrangeiras, tendo em vista que a expressão "autor da herança" contida no inciso II do artigo 89 deixa evidente que a restrição apenas se impõe às sentenças cujo inventário e partilha se deem em decorrência de sucessão mortis causa. ${ }^{73}$

Nada obstante, à louvável evolução interpretativa, em decisão datada de 1987, o Supremo Tribunal Federal, a nosso ver, excedeu-se, ao afirmar:

"Não obstante a peça homologada cuidar de imóvel situado no Brasil, fls. 07, óbice não há à chancela dessa Augusta Presidência, devendo os requerentes, finda a ação homologatória, submetê-la ao juízo brasileiro competente, a fim de que produza os efeitos legais pertinentes (SSEE n. 2883, 3.290, 3.417)."74

\footnotetext{
${ }^{72}$ STF - SE n. 2709 dos Estados Unidos da América, RTJ, 97/69, 1980.

${ }^{73} \mathrm{STF}-\mathrm{SE}$ n. 3.408, Estados Unidos da América, RTJ, 115/1.083, 09 de outubro de 1985.

${ }^{74} \mathrm{STF}$ - SE n. 2.885, Estado de Israel, RTJ, 121/459, 1987.
} 
Uma vez mais, e como já apontado, a existência do bem imóvel, a nosso ver, atrairia a aplicação do inciso I do mesmo artigo 89, bem como dos artigos 325 e 326 do Código Bustamante, pelo que a homologação, nessas hipóteses, deveria ser negada.

Deixou assim de sofrer restrições o acordo de partilha no divórcio incorporado à sentença estrangeira do mesmo divórcio, de modo que às sentenças estrangeiras, nessas hipóteses, não mais se negou eficácia.

Por tratar da jurisdição exclusiva das autoridades judiciárias brasileiras, o artigo em comento veda que se homologue no Brasil sentença estrangeira que verse sobre imóvel situado em território nacional ou trate de inventário e partilha de bens aqui situados. Não terão, portanto, nenhuma eficácia no ordenamento jurídico brasileiro, e, consequentemente, tampouco terá relevância o fato de uma ação com um desses objetos ter sido ajuizada perante uma autoridade judiciária estrangeira.

O artigo 88 do Código de Processo, por sua vez, dispõe:

"Art. 88 - É competente a autoridade judiciária brasileira quando:

I - o réu, qualquer seja a sua nacionalidade, estiver domiciliado no Brasil;

II - no Brasil tiver de ser cumprida a obrigação;

III - a ação se originar de fato ocorrido ou de ato praticado no Brasil.

Parágrafo único - Para o fim do disposto no $\mathrm{n}^{\circ} 1$, reputa-se domiciliada no Brasil a pessoa jurídica estrangeira que aqui tiver agência, filial ou sucursal."

Esse artigo, como já apontado, ao atribuir jurisdição à autoridade judiciária brasileira nas hipóteses em que o réu for aqui domiciliado ou aqui tiver de ser cumprida a obrigação, nada mais faz do que reproduzir o caput do artigo 12 da Lei de Introdução às Normas do Direito Brasileiro. Contudo, inova ao atribuir jurisdição nas hipóteses de ações decorrentes de fato ocorrido ou de ato praticado no Brasil, atendendo à necessidade de se poder apurar a responsabilidade por atos ilícitos ocorridos em território brasileiro.

O inciso I segue a regra decorrente do princípio actio sequitor forum rei, estipulando o elemento domicílio a atrair a jurisdição brasileira, independentemente de qualquer outro, como, por exemplo, a nacionalidade. 
Note-se que a nacionalidade, critério dominante nos países europeus ${ }^{75}$, já foi elemento determinante a atrair a jurisdição nacional, até o Império. Hélio Tornaghi ${ }^{76}$, em um esboço histórico, afirma que em razão da influência do direito romano, que aplicava aos cidadãos o jus civile e aos estrangeiros o jus gentium, as legislações adotavam o elemento nacionalidade como determinante da jurisdição. Esclarece que isso havia ocorrido no Código de Napoleão, no Código de Processo Civil da Itália de 1865, bem como nos Códigos portugueses mais antigos, nos quais havia distinção da jurisdição aplicável, com base na nacionalidade (nacionais ou estrangeiros). Afirma, por fim, que tal critério foi superado, e no Brasil, desde o Império, firmou-se a igualdade entre nacionais e estrangeiros.

Conforme parágrafo único, a regra do domicílio compreende ainda a pessoa jurídica estrangeira que tenha instalado filial, agência ou sucursal em território brasileiro. Note-se que nos termos do artigo 1.138, caput, do Código Civil, a sociedade estrangeira autorizada a funcionar no Brasil é obrigada a ter permanentemente representante em território nacional com poderes para receber citação judicial pela sociedade. ${ }^{77}$

Como bem observado por Maristela Basso, o conceito de domicílio invocado tanto no artigo 88, ora analisado, quanto no artigo 12 da Lei de Introdução às Normas do Direito Brasileiro, será o empregado segundo a lex fori. Portanto, de acordo com os artigos 70 e 71 do Código Civil. ${ }^{78}$

Esses artigos determinam como domicílio da pessoa natural o local onde ela estabelece sua residência com ânimo definitivo. Contudo, pode haver pluralidade de residências. Nesses casos, qualquer uma delas será considerada como seu domicílio. Consequentemente, a jurisdição da autoridade judiciária brasileira não será automaticamente excluída pelo fato da

\footnotetext{
${ }^{75}$ GRECO FILHO, Vicente, Homologação de sentença estrangeira, cit., p. 70. O autor afirma também que a nacionalidade foi o critério preferido por Clóvis Beviláqua como principal elemento de conexão, na primeira Lei de Introdução.

${ }^{76}$ TORNAGHI, Hélio. Comentários ao Código de Processo Civil, cit., v. 1, p. 303 et seq.

77 Vicente Greco afirma que o parágrafo único do artigo 88 criou a ficção da autonomia da agência, filial ou sucursal para o fim de determinar o domicílio no Brasil, independentemente do local de sua sede, com a finalidade de evitar prejuízo ao credor brasileiro (Homologação de sentença estrangeira, cit., p. 71). Ocorre que com a obrigação estipulada no artigo 1.138 do Código Civil, a justa finalidade invocada por esse autor parece não mais existir: "Art. 1.138 - A sociedade estrangeira autorizada a funcionar é obrigada a ter, permanentemente, representante no Brasil, com poderes para resolver quaisquer questões e receber citação judicial para a sociedade."

${ }^{78}$ BASSO, Maristela, Curso de direito internacional privado, cit., p. 268.
} 
pessoa ter domicílio em outros Estados. Necessário será, tão somente, que o demandado tenha também domicílio no Brasil. $^{79}$

Com relação às pessoas jurídicas de direito privado, de acordo com a lex fori, deve-se observar o disposto no artigo 75, inciso IV e seu parágrafo $2^{\circ}$, do Código Civil, segundo o qual o domicílio da pessoa jurídica corresponderá ao local em que funcionarem as respectivas diretorias e administrações, ou, segundo seus estatutos ou ato constitutivos, no local onde tiverem eleito domicílio especial. Ainda que a diretoria ou administração esteja sediada no estrangeiro, o parágrafo $2^{\circ}$ considera como domicílio, nesses casos, o seu estabelecimento no Brasil.

Por fim, o réu com ausência de domicílio será demandado nos termos do artigo $7^{\circ}$, parágrafo $8^{\circ}$, da Lei de Introdução às Normas do Direito Brasileiro. Portanto, em sua residência ou no local onde se encontre.

O inciso II, tenha o réu domicílio no Brasil ou não, estipula que também terá jurisdição a autoridade judiciária brasileira, nas hipóteses em que a obrigação tiver de ser cumprida no Brasil.

Correto o dispositivo. Devendo a obrigação ser cumprida em território nacional, coerente tenha a autoridade judiciária brasileira jurisdição para ação que exige o seu cumprimento. Casos, portanto, envolvendo contratos internacionais em que a obrigação seja exequível em território nacional atraem a jurisdição do juiz brasileiro.

O inciso III estendeu à jurisdição brasileira a ação que decorrer de ato praticado ou fato ocorrido no Brasil. Observa-se que pelo fato do artigo 94, parágrafo $3^{\circ}$, do Código de Processo Civil ${ }^{80}$ tratar claramente de hipótese de distribuição interna de competência, receava a doutrina que as obrigações decorrentes de ato ilícito pudessem não estar incluídas no espectro de causas submetidas à jurisdição do juiz brasileiro, fato que acarretaria prejuízo às vítimas.

\footnotetext{
79 MOREIRA, José Carlos Barbosa. Problemas relativos a litígios internacionais. Revista de Processo, São Paulo, Revista dos Tribunais, v. 17, n. 65, p. 146, 1992; BASSO, Maristela, Curso de direito internacional privado, cit., p. 268.

80 “Art. 94 - [...] $\S 3^{\circ}$ - Quando o réu não tiver domicílio nem residência no Brasil, a ação será proposta no foro do domicílio do autor. Se este também residir fora do Brasil, a ação será proposta em qualquer foro."
} 
O artigo 88, diferentemente do que estipula o artigo 89, não exclui da jurisdição de outros Estados a apreciação das hipóteses nele previstas pela jurisdição de outros Estados, muito embora não afaste a jurisdição da autoridade judiciária brasileira. Por isso se diz, nesses casos, que a jurisdição do juiz nacional concorre com a de juízes de outros Estados que também tenham avocado o poder de dizer o direito nessas mesmas hipóteses.

Nota-se de todo o exposto, sobretudo da expressão "com exclusão de qualquer outra" presente no artigo 89, que o artigo 88 trata da competência concorrente da autoridade judiciária brasileira, enquanto o artigo 89 trata, por sua vez, da competência exclusiva do juiz brasileiro.

Disso decorre que, com relação às causas não abrangidas em nenhum desses dois dispositivos, a jurisdição, a princípio, se mostra exclusiva das autoridades judiciárias estrangeiras. E, no tocante à eficácia das sentenças estrangeiras no território brasileiro, não serão reconhecidas em território nacional as sentenças estrangeiras que tenham por objeto algumas das hipóteses elencadas nos incisos do artigo 89 do Código de Processo Civil.

Cumpre esclarecer que é possível que ocorra, no curso da demanda, alteração de situação fática tida como ponto de conexão com a jurisdição brasileira. Neste caso, Serpa Lopes $^{81}$, muito embora sob a égide do Código de Processo Civil de $1939^{82}$, ensina que a jurisdição internacional não se modifica, sendo-lhe aplicável o princípio da fundamental da inalterabilidade e perdurabilidade da competência. Essa, inicialmente firmada, perpetua-se, sem que haja interferência de quaisquer transformações fáticas ou de direito ocorridas posteriormente à propositura da demanda.

Tal entendimento está disposto no artigo 87 do Código de Processo Civil ${ }^{83}$ vigente, de modo que a jurisdição da autoridade judiciária brasileira não será alterada, por exemplo, em caso de alteração de domicílio do réu. É a consagração do princípio da perpetuatio jurisdictionis.

\footnotetext{
${ }^{81}$ SERPA LOPES, Miguel Maria de, Comentários à Lei de Introdução ao Código Civil, cit., v. 3, p. 95.

${ }^{82}$ O Código de Processo Civil revogado dispunha a regra em seu artigo 151: "Não influirão na competência do juízo as transformações posteriores à propositura da demanda e relativas ao domicílio, à cidadania das partes, ao objeto da causa ou ao seu valor."

83 “Art. 87 - Determina-se a competência no momento em que a ação é proposta. São irrelevantes as modificações do estado de fato ou de direito ocorridas posteriormente, salvo quando suprimirem o órgão judiciário ou alterarem a competência em razão da matéria ou da hierarquia."
} 


\subsubsection{Autonomia da vontade e modificação da competência internacional}

Com relação ao artigo 88, nota-se, portanto, que para as causas ali previstas, não há uma autoridade judiciária com jurisdição e outra desprovida de jurisdição. Ambas são, sob a perspectiva da legislação brasileira, igualmente investidas de jurisdição. Não há que se falar, consequentemente, que um juiz investido de jurisdição tornar-se-ia desprovido dela por força da renúncia de uma das partes, e que outro, desprovido de jurisdição, tornar-se-ia dela investido, simplesmente em virtude da mera submissão de qualquer das partes.

Em outras palavras, o Estado brasileiro reconhece como igualmente investido de jurisdição para a causa tanto o juiz nacional como o estrangeiro. Ora, como já dito anteriormente, essa avocação de jurisdição é ato que se sustenta na soberania do Estado e que decorre do reconhecimento de outras soberanias igualmente dignas, de modo que prevalece sobre qualquer manifestação de vontade das partes, a ponto de não poder ser por elas modificado.

Assim, o simples fato de uma parte ajuizar uma ação perante autoridade judiciária estrangeira não lhe atribuirá competência concorrente, se a lei nacional não lhe houver anteriormente atribuído. Pela mesma razão, a renúncia a se submeter a esse juízo que também detém competência não lhe retirará essa jurisdição, que lhe foi, por ato de soberania, atribuída. $^{84}$

Disso decorre que proposta uma demanda perante uma autoridade judiciária estrangeira que detenha jurisdição concorrente com uma autoridade judiciária brasileira, segundo a nossa lex processualis, não haverá prevenção da jurisdição estrangeira em face da nacional, de modo que não haverá falar em prorrogação dessa jurisdição estrangeira, que é, como dito, concorrente.

Ainda, a exceção de incompetência, quer com fundamento na jurisdição exclusiva, quer com fundamento na jurisdição concorrente do juiz brasileiro, segundo a lex processualis brasileira (lex fori), não poderá ser utilmente oposta perante a autoridade judiciária estrangeira (i) seja porque, segundo Haroldo Valladão, "a lei geral do processo, a que resolve o conflito

\footnotetext{
${ }^{84}$ Pondera nessas situações José Ignácio Botelho de Mesquita: “A opção do autor de ajuizar ação perante o juiz estrangeiro não atribui a este juiz competência concorrente, porque esta já lhe fora, antes, atribuída pela lei nacional." (Da competência internacional e dos princípios que a informam, cit., p. 55).
} 
de leis processuais, a lex processualis, é a lex fori, a lei do foro do tribunal ou juízo no qual se desenvolve o processo" ${ }^{\wedge 5}$, de modo que o juiz estrangeiro avaliará se detém ou não jurisdição, observando as leis do Estado a que pertença, e não a partir das lei processuais brasileiras; (ii) seja porque, de acordo com a lex processualis brasileira, se ambos os juízes, nacional e estrangeiro, detiverem competência, nenhum deles será desprovido de poder jurisdicional e como a exceção de incompetência tem como fundamento a incompetência de ao menos um deles, não terá em que se sustentar; (iii) seja porque, e o que mais nos interessa, tratando-se de hipóteses em que a autoridade judiciária brasileira exercerá com exclusividade a função jurisdicional, a sentença estrangeira, nessas hipóteses, não será homologada no Brasil, tenha oposto ou não o réu qualquer exceção de incompetência perante a autoridade judiciária estrangeira.

Portanto, uma vez mais nos apoiando em Haroldo Valladão ${ }^{86}$, admitida pela lei processual do Estado em que se busca a homologação de uma sentença estrangeira a jurisdição do juiz estrangeiro que a tenha prolatado, pouco ou de nada adiantará a aceitação pelo réu da competência dessa autoridade judiciária, uma vez que já reconhecida por ato de soberania.

Poderá, então, o autor valer-se, ao mesmo tempo, de ambas as jurisdições concorrentes, ou simplesmente optar por uma, sendo mesmo insignificante qualquer ato de renúncia.

Disso decorre, inevitavelmente, que o réu estará atrelado à jurisdição que o autor optar, ou a ambas. Será assim ineficaz, para efeito de homologação de sentença estrangeira, qualquer conduta sua relacionada à submissão a jurisdição internacional da autoridade judiciária estrangeira.

Entretanto, poderão ocorrer decisões conflitantes, e até mesmo contraditórias, nas hipóteses de causas processadas simultaneamente. Nesses casos, haverá de prevalecer a sentença que primeiro alcançar a situação jurídica de coisa julgada, a sentença estrangeira, assim que homologada pelo Superior Tribunal de Justiça, ou a sentença brasileira, tão logo não mais sujeita a qualquer modalidade de recurso.

\footnotetext{
${ }^{85}$ VALLADÃO, Haroldo, Direito internacional privado, cit., v. 3, p. 123.

${ }^{86}$ Ibidem, p. 123 et seq.
} 
Problema que se coloca frente à premissa acima estabelecida, de que a autonomia da vontade das partes não modifica os limites estabelecidos por lei à jurisdição e, portanto, por ato de soberania, é o da situação do pacto de eleição de foro internacional, importando em expressa renúncia à jurisdição nacional e voluntária submissão da controvérsia à jurisdição estrangeira, e suas consequências no tocante à competência internacional do juiz brasileiro.

A questão a se indagar é se não haveria, nessa situação, supressão da competência da autoridade judiciária brasileira por ato fundado na autonomia da vontade privada das partes. Estar-se-ia, nesse caso, por simples ato de vontade consubstanciado em um negócio jurídico processual $^{87}$, subtraindo do Estado brasileiro o conhecimento de uma controvérsia que, dentre os pontos de contato previstos, se acha incluída nos limites de sua jurisdição concorrente.

A nosso sentir, tendo em vista que os limites da jurisdição de cada Estado não podem ser determinados senão por lei que avoque como seu o poder de dizer o direito em relação às situações que lhe forem convenientes e viáveis, mostra-se inoperante a simples vontade das partes, para o efeito de determinar os limites da jurisdição internacional.

Posição diversa é a adotada por Vicente Greco Filho. Afirma o processualista que se deve entender como elemento determinante dos limites da jurisdição do juiz brasileiro a vontade das partes, por meio da cláusula de eleição de foro.

Fundamenta sua posição na aplicação analógica do artigo 111 do Código de Processo Civil às regras de competência internacional, bem como por ser "tradição do Direito Brasileiro a derrogabilidade voluntária da competência territorial". ${ }^{88}$

Assim também Haroldo Valladão, ao afirmar que "a autonomia da vontade estende-se, também, ao processo e, particularmente, à competência, sendo, a respeito, princípio tradicional e universal" ${ }^{\prime 89}$. Excepciona, contudo, a possibilidade da autonomia da vontade prorrogar jurisdições nas hipóteses em que o legislador estabeleceu a competência em caráter de exclusividade.

\footnotetext{
${ }^{87}$ MESQUITA, José Ignácio Botelho de, Da competência internacional e dos princípios que a informam, cit., p. 56.

${ }^{88}$ GRECO FILHO, Vicente, Homologação de sentença estrangeira, cit., p. 97.

${ }^{89}$ VALLADÃO, Haroldo, Direito internacional privado, cit., v. 3, p. 137.
} 
A despeito de Haroldo Valladão afirmar, inclusive, que "no direito comparado positivo a submissão voluntária é admitida, geral e naturalmente, com a transposição às relações internacionais, dos respectivos princípios dos Cods. de Proc. de cada Estado"90, nos parece que para que isso validamente ocorra mostra-se imprescindível permissivo legal consagrando a eficácia da pacto de eleição de foro internacional.

Sendo a avocação de jurisdição ato de soberania, cuja consequência imediata é a relação de precedência lógica existente entre as normas que tratam da competência internacional e as que tratam da distribuição interna de competência, temos que essas últimas não fornecem à causa título de submissão à jurisdição brasileira se, já não tenha sido atribuído por aquelas, de modo que não se mostra tecnicamente aceitável, a nosso ver, o argumento da validade da cláusula de eleição de foro com fundamento na aplicação analógica do disposto no artigo 111 do Código de Processo Civil, representando, nos dizeres de Haroldo Valladão, uma transposição à ordem internacional do quanto estabelecido nesse dispositivo legal.

Entretanto, na medida que os tratados internacionais, desde que ratificados, incorporam-se ao ordenamento jurídico interno, o permissivo legal, a nosso ver, encontra-se no artigo 318 do Código Bustamante ${ }^{91}$. Muito embora o atual Código de Processo Civil tenha entrado em vigor em 1973, não nos parece tenha tratado da matéria a ponto de revogar, expressa ou tacitamente, o dispositivo do Código Bustamante.

Temos, portanto, que não é a simples autonomia da vontade consubstanciada no pacto de eleição de foro internacional que determina se uma causa está ou não submetida à jurisdição internacional estrangeira ou brasileira, se a uma dessas jurisdições a causa já não estiver submetida por lei.

Note-se, por oportuno, como bem observa José Ignácio Botelho de Mesquita ${ }^{92}$, que a submissão das partes, por outro lado, se mostra de extrema importância "como ato de

\footnotetext{
${ }^{90}$ VALLADÃO, Haroldo, Direito internacional privado, cit., v. 3, p. 137.

91 “Art. 318 - O juiz competente, em primeira instância, para conhecer dos pleitos a que dê origem o exercício das ações cíveis e mercantis de qualquer espécie, será aquele a quem os litigantes se submetam expressa ou tacitamente, sempre que um deles, pelo menos, seja nacional do Estado contratante a que o juiz pertença ou tenha nele o seu domicílio e salvo o direito local em contrário.”. Como já esclarecido, o Código Bustamante foi promulgado pelo Decreto n. 18.871 de 13/08/1929.

${ }_{92}$ MESQUITA, José Ignácio Botelho de, Da competência internacional e dos princípios que a informam, cit., p. 57.
} 
renúncia à eficácia da convenção sobre a eleição de foro", toda vez que se pretenda homologar no Brasil uma sentença estrangeira proferida por autoridade judiciária diversa da convencionada pelas partes.

Cabe, neste momento, observar que o projeto do novo Código de Processo Civil (PSL 166/10), em seu artigo $21^{93}$, inciso III, inclui dentre as causas submetidas à jurisdição nacional a vontade de a ela se submeter tácita ou expressamente. Note-se, nessa hipótese, que as partes, assim procedendo, nada criarão a respeito dos limites da jurisdição do juiz brasileiro, apenas irão se servir de jurisdição já avocada por ato de soberania. Em outras palavras, a vontade das partes, nesse caso, dará vida à condição de que o Estado brasileiro fez depender a submissão da causa à sua jurisdição. ${ }^{94}$

Transcrevemos neste ponto conclusão que nos parece elucidar de vez a questão:

"Competindo a cada Estado, por força da soberania nacional, determinar os limites da sua jurisdição, nada impede que o Estado inclua entre os pontos de conexão com a sua jurisdição (além do domicílio do réu, do lugar onde tenha que ser cumprida a obrigação ou quaisquer outros) a voluntária submissão das partes ou a eleição de foro no país." ${ }^{95}$

O projeto do novo Código de Processo Civil, curiosamente, no artigo $24^{96}$, torna dependente o exercício da jurisdição da autoridade judiciária brasileira de uma condição negativa, qual seja, a não existência de pacto elegendo autoridade judiciária estrangeira para conhecer da causa. Naturalmente, desde que não trate de causas em que a autoridade judiciária brasileira detém jurisdição exclusiva, como, aliás, consta do parágrafo único do artigo.

Momento único para alegar a exceção de incompetência de foro em razão do pacto (condição negativa) parece-nos ser a contestação, como se nota da parte final do dispositivo. Não alegada nesse momento, o efeito do pacto se exaure, sendo a causa processada pela

\footnotetext{
93 “Art. 21 - Também caberá à autoridade judiciária brasileira processar e julgar as ações: [...] III - em que as partes, expressa ou tacitamente, se submeterem à jurisdição nacional."

${ }_{94}^{94}$ MESQUITA, José Ignácio Botelho de, op. cit., p. 56.

95 Ibidem, mesma página.

96 “Art. 24 - Não cabem à autoridade judiciária brasileira o processamento e o julgamento das ações quando houver cláusula de eleição de foro exclusivo estrangeiro, arguida pelo réu na contestação. Parágrafo único Não se aplica o disposto no caput às hipóteses de competência internacional exclusiva previstas neste Capítulo."
} 
autoridade judiciária brasileira, desde que se encontre dentre as hipóteses elencadas nos artigos 20 e 21 do projeto do novo Código de Processo Civil. Note-se que não haverá prorrogação da competência, na medida que a autoridade judiciária brasileira já a possui de forma concorrente.

Deixamos o registro, cunhado em primeira impressão, de que o termo "exclusivo" mostra-se irrelevante e mesmo inútil, na medida que caso o foro eleito seja o nacional, a competência da autoridade judiciária brasileira, concorrente, teria como fundamento o artigo 21, inciso III, acima citado.

Cumpre registrar que Haroldo Valladão ${ }^{97}$ já propunha como ponto de conexão com a jurisdição brasileira o elemento volitivo, consubstanciado no pacto de eleição de foro internacional. No anteprojeto do Código de Processo Civil hoje vigente, propunha as seguintes redações aos parágrafos $1^{\circ}$ e $3^{\circ}$ do artigo 66 :

"§ $1^{\circ}$. Além dos casos terminativos de competência constantes do Código de Processo Civil e de outros textos legais, são os tribunais brasileiros competentes: a) se tiverem sido eleitos especialmente (art. 50, $\S 1^{\circ}$, escolha contratual).

$\S 3^{\circ}$. A eleição de foro estrangeiro, pactuada expressa e inequivocamente, será reconhecida se não versar sobre questões de estado ou assuntos de competência exclusiva dos tribunais brasileiros (antes, 4, $2^{\circ}$ ) e se não importar abuso de direito (art. 11) ou ofensa à ordem pública (arts. 12 e 79).”

Como se verifica de todo o exposto, o fato de ser ineficaz a simples vontade das partes para determinar os limites da jurisdição da autoridade judiciária brasileira não significa, porém, que ela seja impermeável à influência de princípios que possam nortear a interpretação, bem como delinear o alcance dos dispositivos legais comentados.

Antes, porém, de analisar os princípios a que nos referimos, faremos breves considerações a respeito do instituto da litispendência internacional.

\subsubsection{Litispendência internacional}

Como já tratado, uma das consequências práticas no plano internacional de se reconhecer a competência concorrente é a possibilidade de submeter a mesma controvérsia a

\footnotetext{
${ }^{97}$ VALLADÃO, Haroldo, Direito internacional privado, cit., v. 3, p. 140.
} 
autoridades judiciárias de Estados diferentes, as quais detenham, naturalmente, jurisdição concorrente, não sendo oponível, nesses casos, a teor do que dispõe o artigo 90 do Código de Processo Civil, a exceção de litispendência. Consequência imediata desse dispositivo é o fato de que a primeira demanda proposta não torna o juízo prevento.

Em que pese Serpa Lopes ${ }^{98}$ esclarecer que a litispendência e a prevenção apresentamse como institutos processuais semelhantes e detalhar suas diferenças, fato é que, no plano internacional, a prevenção é um dos pontos fundamentais da própria litispendência, servindo para determinar a jurisdição, na hipótese de dois ou mais juízes que a detenham de forma concorrente.

Haroldo Valladão ${ }^{99}$, após esclarecer que a exceção de litispendência é consequência do princípio da prevenção, afirma ser esse o princípio razoável que atua para solucionar conflitos positivos ou negativos de jurisdição, não havendo como negar a justiça da admissão da litispendência internacional.

Serpa Lopes ${ }^{100}$, partindo da premissa de que a exceção de litispendência atua com o fim de evitar uma duplicidade de demandas, bem esclarece que a razão de ser do instituto funda-se nos interesses público e privado, que demandam uma unicidade de litígio e de processo. Em decorrência do interesse público, atuaria para evitar duplicidade de demandas e, consequentemente, a possibilidade de decisões conflitantes, contraditórias, tornando muitas vezes inviável sua execução em outros Estados. Com relação ao interesse privado, fundamenta-se no objetivo de evitar gastos inúteis e dispersão de atividades.

A exceção de litispendência atuaria como instituto remediador de tais hipóteses, mostrando-se extremamente razoável que se admita tal exceção nos casos em que a lide esteja submetida à jurisdição de uma autoridade judiciária estrangeira, em condições de poder a respectiva sentença ser homologada. ${ }^{101}$

\footnotetext{
${ }^{98}$ SERPA LOPES, Miguel Maria de, Comentários à Lei de Introdução ao Código Civil, cit., v. 3, p. 98.

${ }^{99}$ VALLADÃO, Haroldo, Direito internacional privado, cit., v. 3, p. 141.

${ }^{100}$ SERPA LOPES, Miguel Maria de, op. cit., v. 3, p. 98.

${ }^{101}$ Ibidem, v. 3, p. 99-100; VALLADÃO, Haroldo, Direito internacional privado, cit., v. 3, p. 143.
} 
Outro não é o entendimento encontrado no direito convencional, a partir do qual o artigo 394 do Código Bustamante ${ }^{102}$ abria a possibilidade de se opor essa exceção.

Ocorre que o atual Código de Processo Civil regulou especificamente a matéria, acarretando, em decorrência do princípio da lex posterior derogat priori, a não aplicação do dispositivo convencional. Críticas a essa regulação não faltaram.

Haroldo Valladão, após afirmar que o direito brasileiro inovou contra a doutrina e contra o precedente internacional estabelecido no Código Bustamante, ponderou ser incompreensível que o Código de Processo de 1973 “aprovado às carreiras no Congresso, em três meses, sem a devida apreciação dos seus textos, viesse em seu art. 90, copiado do art. do CPC da Itália, às vezes com as mesmas palavras, condenar a litispendência e a conexão com referência a ação intentada perante tribunal estrangeiro". ${ }^{103}$

Por outro lado o Protocolo de Las Leñas ${ }^{104}$ sobre cooperação e assistência jurisdicional em matéria civil, comercial, trabalhista e administrativa parece admitir a prevenção da jurisdição em que primeiramente foi proposta a demanda, possibilitando a oposição da exceção de litispendência em seu artigo 22, que determina:

\footnotetext{
“Artigo 22 - Quando se tratar de uma sentença ou de um laudo arbitral entre as mesmas partes, fundamentado nos mesmos fatos, e que tenha o mesmo objeto de outro processo judicial ou arbitral no Estado requerido, seu reconhecimento e sua executoriedade dependerão de que a decisão não seja incompatível com outro pronunciamento anterior ou simultâneo proferido no Estado requerido.

Do mesmo modo não se reconhecerá nem se procederá à execução, quando se houver iniciado um procedimento entre as mesmas partes, fundamentado nos mesmos fatos e sobre o mesmo objeto, perante qualquer autoridade jurisdicional da Parte requerida, anteriormente à apresentação da demanda perante a autoridade jurisdicional que teria pronunciado a decisão da qual haja solicitação de reconhecimento."
}

\footnotetext{
102 “Art. 394 - A litispendencia, por motivo de pleito em outro Estado contractante poderá ser allegada em materia civel, quando a sentença, proferida em um delles, deva produzir no outro os effeitos de cousa julgada."

${ }^{103}$ VALLADÃO, Haroldo, op. cit., v. 3, p. 143. Serpa Lopes esclarece que na jurisprudência de países como Itália e Inglaterra prevalecia, à época, a noção de ser a litispendência matéria voltada a circunstância que envolvia apenas o processo interno (op. cit., v. 3, p. 99).

104 O Protocolo de Las Leñas encontra-se em vigor no Brasil por força do Decreto n. 2.067, de 12/11/1996, $D O U$, de 13/11/1996. Encontra-se em vigor nos quatro países membros do Mercosul: Brasil, Argentina, Paraguai e Uruguai.
} 
Assim, da segunda parte desse dispositivo, nota-se haver a consagração em nível regional do princípio da prevenção, ou da não simultaneidade. ${ }^{105}$

Nota-se, contudo, que o artigo 22 do Protocolo de Las Leñas não revogou o artigo 90 do Código de Processo Civil vigente. Revela-se como uma norma especial e, portanto, restrita aos países signatários, de modo que sua aplicação, ou seja, a oposição da exceção de litispendência, restringe-se às ações intentadas somente nesses países. O artigo 90 do Código de Processo Civil terá plena vigência quando se tratar de outros países, revelando-se norma de caráter geral. ${ }^{106}$

Pode-se dizer, em observância ao quanto disposto até agora, que, exceto nos casos de regras especiais previstas em tratados internacionais, não é oponível a exceção de litispendência internacional. Em outras palavras, não haverá prevenção da jurisdição, de modo que a ação promovida perante a Justiça de outro Estado não obsta a propositura de igual demanda perante a Justiça brasileira e tampouco a propositura de uma demanda perante a autoridade judiciária brasileira servirá como fundamento de recusa à homologação de sentença estrangeira proferida em idêntica demanda.

Haverá de prevalecer nessas situações a sentença que primeiro alcançar a situação jurídica de coisa julgada, a sentença estrangeira, assim que homologada pelo Superior Tribunal de Justiça, ou a sentença brasileira tão logo não mais sujeita a qualquer modalidade de recurso.

Cumpre esclarecer que de acordo com a premissa adotada de que, ao limitar a extensão da sua jurisdição, o Estado reconhece que a outros Estados deva ser submetida a composição de determinadas lides. E se assim o faz é porque reconhece como igualmente legítimo o poder jurisdicional desse outro Estado, cujos provimentos jurisdicionais haverão de ser tão eficazes quanto os seus, o que implica em última análise reconhecer na sentença estrangeira uma verdadeira sentença. Seria assim coerente admitir a possibilidade de se arguir a exceção de litispendência, de modo que podemos considerar o artigo 90 do Código de Processo Civil incoerente com o sistema adotado de limitar o poder jurisdicional do Estado.

\footnotetext{
${ }^{105}$ BASSO, Maristela, Curso de direito internacional privado, cit., p. 280-282.

${ }^{106}$ Ibidem, p. 282.
} 
Tal sistema importa em admitir a homologação da sentença estrangeira e, assim, tornála apta à execução em território nacional. Ora, se se admite que um tribunal estrangeiro processe uma demanda que poderá ser homologada e executada em território nacional, é porque se admite que a decisão que emitiu é legítima, evidentemente não nas hipóteses de competência exclusiva da autoridade judiciária brasileira. Assim, a nosso ver, não há justificativa plausível para não se admitir e reconhecer a existência de processo em andamento no exterior como legítimo, a evitar que a mesma demanda seja proposta e decidida em território nacional, e que alcançaria, ao menos em tese, o mesmo resultado.

Registramos por oportuno que o projeto do novo Código de Processo Civil, ao tratar do instituto da litispendência em seu artigo $23^{107}$, nada acrescenta ao já disposto no vigente artigo 90. Apenas reproduz o referido artigo, acrescentando, desnecessariamente, a ressalva do regramento estipulado em tratados e convenções internacionais, bem como em seu parágrafo único afirma também o desnecessário, ou seja, que a pendência de causa perante a jurisdição brasileira em nada obsta a homologação de sentença judicial ou arbitral estrangeira, a nosso ver, consequências práticas do instituto da litispendência, como decorrência do princípio da prevenção ao qual está atrelado.

\subsubsection{Princípios que informam as regras de competência internacional}

Após a análise dos pontos de conexão utilizados pelo legislador pátrio para tornar a causa afeta à jurisdição brasileira e do artigo 90 do Código de Processo, convém esclarecer que o fato de ser ineficaz a simples vontade das partes para determinar os limites da jurisdição internacional não significa, porém, que essas regras sejam impermeáveis à influência de princípios que possam nortear a interpretação, bem como delinear o alcance dos dispositivos legais comentados.

Trataremos, neste momento, de dois princípios que informam a interpretação das regras de competência, dita internacional, da autoridade judiciária brasileira.

\footnotetext{
107 “Artigo 23 - A ação proposta perante tribunal estrangeiro não induz litispendência não obsta que a autoridade judiciária brasileira conheça da mesma causa e das que lhe são conexas, ressalvadas as disposições em contrário de tratados internacionais e acordos bilaterais em vigor no Brasil. Parágrafo único - A pendência de causa perante a jurisdição brasileira não impede a homologação de sentença judicial ou arbitral estrangeira."
} 
Amílcar de Castro ${ }^{108}$, após ponderar que o poder de dizer o direito sobre fatos ocorridos no estrangeiro não é absoluto, afirma que "no silêncio da lei, o exercício da jurisdição arrima-se em dois princípios: o da efetividade e o da submissão".

Trataremos inicialmente do princípio da efetividade. Para Amílcar de Castro, esse princípio significa que o juiz seria incompetente para proferir sentenças que não fossem possíveis de serem por ele executadas, o que não excluiria, contudo, a possibilidade da jurisdição ser exercida sobre pessoas que se encontrassem domiciliadas fora do território nacional e, portanto, fora do poder do tribunal. Afirma que, sem texto de lei, o tribunal deverse-ia declarar desprovido de jurisdição "quando as coisas, ou o sujeito passivo, estejam fora de seu alcance, isto é, do alcance da força de que dispõe". ${ }^{109}$

Ao analisar o princípio, José Ignácio Botelho de Mesquita ${ }^{110}$ afirma que uma das hipóteses em que se evidencia a aplicação do princípio da efetividade seria nos casos de execução de sentença estrangeira em que não concorram nenhuma das hipóteses do artigo 88 do Código de Processo Civil, muito embora estejam no Brasil os bens sobre os quais devam recair os atos executórios.

Nesses casos de execução forçada, tendo em vista que ao Estado pertence o exercício da força para a realização do direito no âmbito de seu território, dever-se-ia considerar como de competência exclusiva da autoridade brasileira a prática de tais atos. Tal fato, conforme exposto por José Ignácio, revelaria o interesse jurídico do Estado brasileiro em processar a causa. ${ }^{111}$

No entanto, a rigor não se nota a ausência de lei, como ponderou Amílcar de Castro na sua concepção de aplicação do princípio. O próprio processualista, nesse caso, afirma que a competência da autoridade judiciária brasileira resultaria do método de determinação indireta de competência de que já falamos brevemente. Decorreria, segundo ele, no exemplo dado,

\footnotetext{
${ }^{108}$ CASTRO, Amílcar de, Direito internacional privado, cit., p. 537.

${ }^{109}$ Ibidem, mesma página.

${ }^{110}$ MESQUITA, José Ignácio Botelho de, Da competência internacional e dos princípios que a informam, cit., p. 59 .

${ }^{111}$ Ibidem, p. 59.
} 
mediatamente do disposto no artigo 109, X, da Constituição Federal, combinado com o artigo 658 do Código de Processo Civil. ${ }^{112}$

Haveria ainda outros três casos em que se revelaria a aplicação do princípio da efetividade, ocasião na qual o princípio atuaria como excludente de competência da autoridade judiciária brasileira.

São eles: (i) causa que impliquem a aplicação do direito brasileiro, no entanto a sentença apenas poderia ser utilmente executada no exterior, porém em Estado que não reconheça eficácia às sentenças estrangeiras; nesse caso, a sentença proferida pela autoridade judiciária brasileira se revestiria de completa inutilidade para as partes; (ii) causas em que as regras de direito internacional privado determinem seja aplicado o direito estrangeiro sem que, no entanto, a sentença produza ou deva produzir algum efeito em território nacional; não haveria utilidade para o Estado nesses casos; e (iii) casos de execução de sentenças ou de títulos executivos extrajudiciais que versem sobre bens situados fora do território nacional, pessoas aqui não domiciliadas e títulos executivos extrajudiciais que não especificarem o Brasil como lugar de cumprimento da obrigação ali estipulada; nesses casos, os atos executórios encontrariam limites na jurisdição exclusiva do Estado onde devam ser praticados com exclusividade. ${ }^{113}$

Nas hipóteses acima expostas, ainda que seja o réu domiciliado no Brasil, e assim presente uma das hipóteses do artigo 88 do Código de Processo Civil, haveria de se declarar incompetente a autoridade judiciária brasileira. ${ }^{114}$

Não obstante, notamos ainda um elemento de contato com o ordenamento jurídico brasileiro (o domicílio do réu), de modo que faltaria, para a aplicação do princípio nos moldes concebidos por Amílcar de Castro, o requisito "ausência de lei”. Nada obstante, o exposto por José Ignácio, a nosso ver, bem delineia o alcance das normas de competência internacional, de modo a não se apresentarem inflexíveis, a ponto de sua aplicação se mostrar inútil.

\footnotetext{
${ }^{112}$ MESQUITA, José Ignácio Botelho de, Da competência internacional e dos princípios que a informam, cit., p. 59.

${ }^{113}$ Ibidem, mesma página.

${ }^{114}$ Ibidem, mesma página.
} 
O princípio da submissão, segundo Amílcar de Castro ${ }^{115}$, significaria que "em limitado número de casos, uma pessoa pode voluntariamente submeter-se à jurisdição de tribunal a que não estava sujeita, pois se começa por aceitá-la não pode depois pretender livrar-se dela”. Afirma, contudo, que o referido princípio esbarraria em duas limitações: "Não prevalece onde se encontre estabelecida por lei a competência da justiça estrangeira, e não resiste ao princípio da efetividade". Desse modo, podemos dizer que, no silêncio da lei, o tribunal deve declararse incompetente sempre que não tiver certeza de que poderá executar seu julgado.

A aplicação do princípio mostra-se dependente, portanto, de que a causa não esteja prevista dentre as hipóteses que, segundo a lex fori do Estado a ser submetida a demanda, sua autoridade judiciária deteria competência. Cabe ressaltar que não haverá falar em aplicação do princípio da submissão, caso a lex fori do Estado a que o tribunal pertencer incluir dentre os limites de sua jurisdição internacional as lides que lhe forem submetidas voluntariamente pelas partes. Como exemplo, temos o projeto do novo Código de Processo Civil que, conforme já tratado, em seu artigo 21, inciso III, faz depender a competência, dita internacional, da autoridade judiciária brasileira da vontade das partes de se submeterem a ela. Nesses casos, o que ocorre é aplicação da lei, fruto do poder soberano do Estado, o qual, por motivos de conveniência e viabilidade, decidiu incluir no alcance de sua jurisdição as referidas hipóteses. Não se vislumbra aplicação do princípio da submissão nessas hipóteses. ${ }^{116}$

Note-se, por derradeiro, que sendo proposta a demanda perante autoridade judiciária de tribunal que detenha competência, segundo a lex processualis do Estado a que pertence, muito embora tenha o réu domicílio em outro Estado, não terá ele o direito de se recusar a se submeter à jurisdição desse tribunal estrangeiro, exceto se a competência do tribunal estrangeiro, segundo a mesma lex processualis, depender da submissão espontânea deste réu estrangeiro ou domiciliado fora de seu território. O réu, então, poderá se recusar a se submeter à jurisdição desse Estado, nesse caso, porém, não por força do princípio em comento, mas por força de lei. ${ }^{117}$

\footnotetext{
${ }^{115}$ CASTRO, Amílcar de, Direito internacional privado, cit., p. 538.

${ }^{116}$ MESQUITA, José Ignácio Botelho de, Da competência internacional e dos princípios que a informam, cit., p. 64.

${ }^{117}$ Ibidem, p. 64-65.
} 
Em conclusão, podemos dizer que seriam os casos em que não se incluindo a causa dentre as hipóteses previstas nos artigos 88 e 89 do Código de Processo Civil, poderia, mesmo assim, ser decidida pela autoridade judiciária brasileira, caso ela disponha do poder de fazer executar a decisão proferida e, desde que o réu a ela tenha se submetido sem qualquer oposição. Haroldo Valladão ${ }^{118}$ afirma que nesses casos há um conflito negativo de jurisdição e que, diante da inexistência de um tribunal que detenha expressamente jurisdição para sancionar o direito, "poderá o tribunal dum Estado julgar-se competente para evitar uma denegação de justiça".

${ }^{118}$ VALLADÃO, Haroldo, Direito internacional privado, cit., v. 3, p. 132. 


\section{CAPÍTULO II - SENTENÇA ESTRANGEIRA}

\subsection{Sentença estrangeira no direito brasileiro}

Não havia tratamento específico da problemática do reconhecimento das sentenças estrangeiras no direito brasileiro até 1878, quando da entrada em vigor do Decreto n. 6.982, de 27 de julho. Vicente Greco Filho afirma que as Ordenações do Reino vigentes da época colonial ao primeiro Império não tratavam do tema. Tampouco o teria feito o Regulamento $\mathrm{n}$. 737, que se referiu apenas a algumas hipóteses de cumprimento de contratos elaborados em território estrangeiro e que poderiam produzir efeitos em território nacional. ${ }^{119}$

O Decreto n. 6.982, muito embora não tenha disciplinado especificamente o processo de homologação, mesmo porque ele não existia, veio a regulamentar a execução das sentenças cíveis ou comerciais estrangeiras, estabelecendo alguns requisitos para que pudessem ser aqui executadas.

Dentre os requisitos previstos no artigo $1^{\circ}$ do Decreto n. $6.982^{120}$, não constava devesse ser realizada qualquer revisão de mérito, pelo que o sistema adotado foi o da delibação, embora não houvesse disposição expressa a respeito. Nada obstante, em seu artigo $2^{\circ}$, havia limites que impediam a sentença de ser executada, dentre os quais podemos citar contrariedade à ordem pública ou à leis de observância obrigatória em território nacional e ofensa à leis que regulam a organização da propriedade territorial ou os costumes morais. ${ }^{121}$

Tendo em vista não haver sido estipulado um procedimento homologatório específico e prévio à execução, a sentença estrangeira era apresentada diretamente ao juiz competente para a execução, o qual, aqui a nosso ver o primor do decreto, realizava incidentalmente o

\footnotetext{
${ }^{119}$ MOREIRA, José Carlos Barbosa. Comentários ao Código de Processo Civil. Rio de Janeiro: Forense, 2010. v. 5, p. 57; GRECO FILHO, Vicente, Homologação de sentença estrangeira, cit., p. 37; HUCK, Hermes Marcelo, Sentença estrangeira e lex mercatoria: horizontes e fronteiras do comércio internacional, cit., p. 2425; SERPA LOPES, Miguel Maria de, Comentários à Lei de Introdução ao Código Civil, cit., v. 3, p. 204; VALLADÃO, Haroldo, Direito internacional privado, cit., v. 3, p. 186.

${ }^{120} \mathrm{O}$ artigo $1^{\circ}$ dispunha que apenas poderiam ser executadas no Brasil as sentenças estrangeiras cíveis ou comerciais que contivessem os requisitos: "§ $1^{\circ}$ - Que a nação, a que pertencem os Juizes ou Tribunaes que as proferiram, admitta o principio da reciprocidade. $\S 2^{\circ}$ - Que venham revestidas das formalidades externas necessarias para torná-las executorias, segundo a legislação do respectivo Estado. $\S 3^{\circ}$ - Que tenha passado em julgado. $\S 4^{\circ}$ - Que estejam devidamente authenticadas pelo Consul brazileiro. $\S 5^{\circ}$ - Que sejam acompanhadas da traduç̧ão em vulgar por interprete juramentado."

${ }^{121}$ GRECO FILHO, Vicente, op. cit., p. 38-39; HUCK, Hermes Marcelo, op. cit., p. 24-25.
} 
juízo de delibação, exarando o "cumpra-se", uma vez presentes os requisitos do artigo $1^{\circ}$ e sem que também houvesse desrespeito às limitações do artigo $2^{\circ}$. Havia, portanto, restrita atividade cognitiva, limitada à verificação de pressupostos extrínsecos e intrínsecos, e de modo incidental. Após, procedia à execução segundo as regras vigentes no Império para a execução das sentenças nacionais. ${ }^{122}$

Oportuno destacar que o artigo 12 do decreto assegurou a qualidade de coisa julgada às sentenças cíveis e comerciais estrangeiras mesmo que não submetidas ao "cumpra-se". Assim ainda que não postas à execução, produziriam os efeitos decorrentes da situação jurídica de coisa julgada uma vez presentes os requisitos do artigo $1^{\circ}$ e desde que não houvesse afronta ao quanto disposto no artigo $2^{\circ}$. Ficava evidente, desde então, que apenas a eficácia executiva da sentença estrangeira dependia de homologação. Fato que revela a concepção que se tinha da sentença estrangeira antes de homologada. Era tida como verdadeira sentença, como verdadeiro ato jurisdicional. ${ }^{123}$

Em que pesem os elogios ao avanço internacionalista do Decreto n. 6.982, exigia ele o requisito da reciprocidade para que aqui pudessem ser executadas as sentenças estrangeiras, requisito que veio a ser abrandado pelo Decreto n. 7.777, de 27 de julho de 1880, por meio do qual o retrógrado requisito poderia ser suprido por um exequatur concedido pelo governo. ${ }^{124}$

Fato é que o Decreto n. 6.982 instituiu entre nós o sistema de delibação, realizado incidentalmente na própria execução, “com conteúdo declaratório, eminentemente jurisdicional", nos dizeres de Vicente Greco Filho. O processualista, após concordar com Amílcar de Castro sobre o fato do direito internacional privado não poder se fundamentar na exigência de reciprocidade, pondera que o "sistema do Decreto n. 6.982 poderia ser considerado dos mais internacionalistas do mundo, inclusive em relação ao vigente no Brasil, porquanto deferia ao próprio juiz da execução, com recurso previsto em lei, a decisão sobre o

\footnotetext{
${ }^{122}$ Vicente Greco afirma, referindo-se ao Conselheiro Lafayette Rodrigues Pereira: "O diploma é verdadeira obra-prima do gênio jurídico brasileiro, deixando traçadas, desde então, as linhas básicas do instituto em grau de desenvolvimento ainda hoje não atingido por muitas das legislações de povos civilizados [...]." (Homologação de sentença estrangeira, cit., p 38).

${ }^{123}$ MOREIRA, José Carlos Barbosa, Comentários ao Código de Processo Civil, cit., v. 5, p. 57; GRECO FILHO, Vicente, op. cit., p. 39; HUCK, Hermes Marcelo, Sentença estrangeira e lex mercatoria: horizontes e fronteiras do comércio internacional, cit., p. 24 et seq.; SERPA LOPES, Miguel Maria de, Comentários à Lei de Introdução ao Código Civil, cit., v. 3, p. 204-205.

${ }^{124}$ MOREIRA, José Carlos Barbosa, op. cit., v. 5, p. 57; GRECO FILHO, Vicente, op. cit., p. 40-41; SERPA LOPES, Miguel Maria de, op. cit., v. 3, p. 205.
} 
'cumpra-se', em caráter incidental, independentemente do processo formal de homologação" 125. Concordamos com a ponderação, inclusive nos dias atuais, especialmente fosse o sistema adotado para a execução de laudos arbitrais estrangeiros.

Haroldo Valladão ${ }^{126}$ destaca que o país precursor a instituir o sistema de delibação havia sido a Itália, no século XIX, que em seu Código de Processo de 1865 admitia sem condição de reciprocidade a execução de sentenças estrangeiras, através de "simples giudizio di delibazioni" em um processo sumário sem revisão de mérito, cuja tramitação dava-se perante a Corte de Apelação. Havia, segundo o mestre, apenas um controle extrínseco, no qual aferiam-se apenas os requisitos de competência, revelia e não ofensa à ordem pública.

O mesmo autor afirma ainda que esse foi o sistema adotado no direito português, cuja positivação se deu no Código de Processo de 1876, com as exigências adicionais de coisa julgada e da aplicação do direito português, o que veio a influenciar o direito brasileiro, como visto acima nos Decretos de 1878 e $1880 .{ }^{127}$

Na República, o Decreto n. 848, de outubro de 1890, não regulou a matéria, de modo que se mantiveram vigentes as normas do Decreto 6.982, com o abrandamento do requisito da reciprocidade por meio do Decreto n. 7.777, até que a Lei n. 221, de 20 de novembro 1894, que tratou da organização da Justiça Federal, regulou parcialmente a matéria, permanecendo, no entanto, ainda em vigor as disposições do Decreto n. 6.982, que não foram tratadas de forma diversa. ${ }^{128}$

Importante notar que não mais se exigia, a partir de então, o requisito da reciprocidade, restando consignada expressamente, nos termos do artigo 12, parágrafo 4", "b", 5, parte final, da Lei n. 221, também a vedação à produção de provas sobre a questão de

125 GRECO FILHO, Vicente, Homologação de sentença estrangeira, cit., p. 40. Assim também Haroldo Valladão, afirmando que o Decreto, ao invocar princípios à época dos mais avançados, admitia execução ampla das sentenças estrangeiras (Direito internacional privado, cit., v. 3, p. 186).

${ }^{126}$ VALLADÃO, Haroldo, op. cit., v. 3, p. 182. Também nesse sentido: MOREIRA, José Carlos Barbosa, Comentários ao Código de Processo Civil, cit., v. 5, p. 56.

${ }^{127}$ VALLADÃO, Haroldo, op. cit., v. 3, p. 182. O autor, no entanto, faz a ressalva de que a Itália passou a restringir fortemente o sistema de delibação tal como adotado, exigindo em certos casos a revisão de mérito do julgado, referindo-se aos artigos 796 a 798 do Código de Processo de 1940. Também nesse sentido: MOREIRA, José Carlos Barbosa, op. cit., v. 5, p. 61-62.

${ }^{128}$ GRECO FILHO, Vicente, op. cit., p. 41; SERPA LOPES, Miguel Maria de, Comentários à Lei de Introdução ao Código Civil, cit., v. 3, p. 205; VALLADÃO, Haroldo, op. cit., v. 3, p. 187 et seq. 
fundo, o que significava vedação a qualquer revisão sobre a questão de mérito da sentença estrangeira, consequência direta da opção pelo sistema de delibação. ${ }^{129}$

Haroldo Valladão ${ }^{130}$ afirma que a grande novidade republicana introduzida pela Lei n. 221 de 1894 foi transferir a competência do juízo de homologação para o Supremo Tribunal Federal, fato que aproximava ainda mais o sistema brasileiro do italiano ${ }^{131}$. A matéria foi integralmente tratada no artigo 12 , parágrafo $4^{\circ}$, da Lei. ${ }^{132}$

A Consolidação das Leis da Justiça Federal, aprovada pelo Decreto n. 3.084, de 5 de novembro de 1898, ao fundir as disposições da Lei n. 221 com o texto da Constituição de 1891, disciplinou completamente a matéria nos artigos $7^{\circ}$ a $19^{133}$, mantendo, inclusive,

${ }^{129}$ MOREIRA, José Carlos Barbosa, Comentários ao Código de Processo Civil, cit., v. 5, p. 57; GRECO FILHO, Vicente, Homologação de sentença estrangeira, cit., p. 43; VALLADÃO, Haroldo, Direito internacional privado, cit., v. 3, p. 187e 205.

${ }^{130}$ VALLADÃO, Haroldo, op. cit., v. 3, p. 187. Também nesse sentido: MOREIRA, José Carlos Barbosa, op. cit., v. 5 , p. 56.

${ }^{131}$ GRECO FILHO, Vicente, op. cit., p. 41; VALLADÃO, Haroldo, op. cit., v. 3, p. 187.

132 "§ $4^{\circ}$ - As rogatorias emanadas de autoridades estrangeiras serão cumpridas somente depois que obtiverem o exequatur do Governo Federal, sendo exclusivamente competente o juiz da seccional do Estado, onde tiverem de ser executadas as diligencias deprecadas. As cartas de sentença, porém, de tribunaes extrangeiros, não serão exequiveis sem previa homologação do Supremo Tribunal Federal com audiencia das partes e do Procurador Geral da Republica, salvo si outra cousa estiver estipulada em tratado. No processo de homologação observarse-ha o seguinte: a) distribuida a sentença extrangeira, o relator mandará citar o executado, para em oito dias, contados da citação, deduzir por embargos a sua opposição, podendo o exequente em igual prazo contestal-os; b) pode servir de fundamento para a opposição: $1^{\circ}$, qualquer duvida sobre a authenticidade do documento ou sobre a intelligencia da sentença; $2^{\circ}$, não ter a sentença passado em julgado; $3^{\circ}$, ser a sentença proferida por juiz ou tribunal incompetente; $4^{\circ}$, não terem sido devidamente citadas as partes ou não se ter legalmente verificado a revelia, quando deixarem de comparecer; $5^{\circ}$, conter a sentença disposição contraria á ordem publica ou ao direito publico interno da União; Em caso algum é admissivel a producção de provas sobre o fundo da questão julgada. c) em seguida á contestação, ou findo o prazo para ella destinado, terá vista o procurador geral da Republica, e com o parecer deste irá o processo ao relator e sucessivamente aos dous revisores, na forma estabelecida para as appellações no Regimento Interno do Tribunal; d) confirmada a sentença extrahir-se-há a competente carta, a que se addicionará a sentença homologada, para ser executada no juizo seccional, a que pertencer; e) si a execução da sentença extrangeira for requisitada por via diplomatica, sem que compareça o exequente, o tribunal nomeará ex-officio um curador, que represente a este e promova em seu nome todos os termos do processo; Igual procedimento guardar-se-ha em relação ao executado, si não comparecer, ausente, menor ou interdicto."

${ }^{133}$ Reproduzimos o texto do Decreto referente a esses artigos: "Da Homologação das Sentenças Extrangeiras Art. $7^{\circ}$ - As cartas de sentença de tribunaes extrangeiros não serão exequíveis sem previa homologação do Supremo Tribunal Federal com audiencia das partes e do Procurador Geral da Republica. Art. $8^{\circ}$ - As sentenças extrangeiras, cíveis ou comerciaes, só poderão ser homologadas, concorrendo os seguintes requisitos: $1^{\circ}$ - Que venham revestidas de formalidades externas necessarias para torna-las executórias, segundo a legislação do respectivo Estado. $2^{\circ}$ - Que tenham sido proferidas por juiz competente, citadas as partes ou legalmente verificada sua revelia, segundo a mesma legislação. $3^{\circ}$ - Que tenham passado em julgado. $4^{\circ}$ - Que estejam devidamente authenticadas pelo consul brazileiro. $5^{\circ}$ - Que sejam acompanhadas da traducção em vulgar por interprete. Art. $9^{\circ}$ - Não obstante concorrerem os requisitos do artigo antecedente, as ditas sentenças não serão homologadas, si contiverem decisão contrária á ordem publica ou o direito publico interno da União. Art. 10 No processo da homologação observar-se-ha o seguinte: $1^{\circ}$, distribuida a sentença estrangeira, o relator mandará citar o executado para em oito dias contados da citação deduzir por embargos a sua opposição, podendo o exequente em igual prazo contestal-os. $2^{\circ}$, póde servir de fundamento para a opposição: a) qualquer 
trechos da Lei n. 221, bem como do Decreto n. 6.982, de 27 de julho de 1878, que regulava a execução das sentenças cíveis e comerciais dos tribunais estrangeiros. ${ }^{134}$

Com a entrada em vigor do antigo Código Civil, a Lei de Introdução dispunha basicamente em seu artigo 16 que "as sentenças dos tribunais estrangeiros seriam exequíveis

duvida sobre a authenticidade do documento ou sobre a intelligencia da sentença; b) a falta de algum dos requisitos enumerados nos arts. 8 e 9 . Em caso algum é admissível a produção de provas sobre o fundo da questão julgada; $3^{\circ}$, em seguida á contestação, ou findo o prazo para ella destinado, terá vista o Procurador Geral da Republica e com o parecer deste irá o processo ao relator e sucessivamente aos dous revisores, na fórma estabelecida para as appellações; $4^{\circ}$, confirmada a sentença, extrahir-se-ha a competente carta a que se addicionará a sentença homologada para ser executada no juizo seccional a que pertencer; $5^{\circ}$, si a execução da sentença extrangeira for requisitada por via diplomática, sem que compareça o exequente, o tribunal nomeará ex-officio um curador, que represente a este e promova em seu nome todos os termos do processo. Igual procedimento guardar-se-ha em relação ao executado, si não comparecer, estiver ausente ou for menor ou interdicto. Art. 11 - O processo de execução e seus diversos modos e incidentes serão regulados pelas leis, estylos e praticas que vigoram na Republica para a execução das sentenças nacionaes da mesma natureza. A interpretação, porem, da sentença e seus effeitos immediatos serão determinados pela lei do paiz onde tal sentença foi proferida. Art. 12 - Nos seis dias que se seguirem á penhora nas acções pessoaes e nos dez dias para a entrega das cousas reaes, é permittido ao executado oppor à sentença embargos que não sejam de nullidade ou infringentes do julgado. Art. 13 - Quando a sentença for julgada inexequivel, os papeis, documentos e mais provas em que ella se fundar poderão ser exhibidos nas acções que pelo mesmo objecto se intentarem na Republica, e serão aceitos pelo que em direito valerem. Art. 14 - Carecem de homologação para serem executadas: a) as sentenças extrangeiras de partilha; b) as sentenças extrangeiras meramente declaratórias, como são as que julgam questões de estado das pessoas; c) as sentenças arbitraes homologadas por tribunaes extrangeiros. Art. 15 - Não serão susceptiveis de execução no Brazil as sentenças extrangeiras que declarem a fallencia de commerciante aqui domiciliado, sendo brazileiro. Art. 16 - As sentenças extrangeiras que abrirem fallencia a commerciantes que tenham domicilio no paiz onde foram proferidas, produzirão na Republica depois de homologadas os effeitos por direito inherente às sentenças de declaração de fallencia, salvo as seguintes restrições: $1^{\circ}$ Independentemente da homologação e só com a exhibição da sentença e do acto de nomeação, em fórma authentica, os syndicos, administradores, ou outros curadores ou representantes legaes da massa terão qualidade para, como mandatários, requererem na Republica diligencias conservatorias dos direitos da massa, cobrar dividas, transigir, si para isso tiverem poderes, e intentar acções, sem obrigação de prestar fiança às custas. $2^{\circ}$ Todos os actos que importarem execução de sentença, taes como arrecadação e arrematação de bens do fallido, não poderão ser praticados sinão depois que a sentença se tornar executoria pela homologação e mediante autorisação do juiz brazileiro, guardando-se as formulas do direto patrio. $3^{\circ}$ Não obstante haver sido declarada executoria a sentença estrangeira de abertura de fallencia, os credores domiciliados na Republica, que tiverem hypotheca sobre bens aqui situados, não ficam inhibidos de demandar os seus creditos e manter os bens hypothecados. $4^{\circ}$ Aos credores chirographarios, domiciliados na Republica, que tiverem, na data da homologação, acções ajuizadas contra os fallidos, é licito prosseguir nos termos ulteriores do processo e executar os bens do fallido sito na Republica. Art. 17 - A sentença extrangeira que abrir fallencia a commerciantes que tenham dous estabelecimentos, um no paiz de seu domicilio e outro distincto e separado na Republica, sendo homologada, não comprehenderá em seus effeitos o estabelecimento existente na Republica. Art. 18 - As concordatas e os modos de prevenir e obstar a declaração de fallencia, homologadas por tribunaes estrangeiros, ficam sujeitos à homologação nos termos dos artigos anteriores e só serão obrigatorios para os credores residentes no Brazil que houverem sido citados para nelles tomarem parte. Art. 19 - No caso de haver tratado ou convenção regulando a execução das sentenças extrangeiras, observar-seha o que a este respeito se achar estipulado." (GRECO FILHO, Vicente, Homologação de sentença estrangeira, cit., p. 44-46).

134 MOREIRA, José Carlos Barbosa, Comentários ao Código de Processo Civil, cit., v. 5, p. 58; GRECO FILHO, Vicente, op. cit., p. 44; SERPA LOPES, Miguel Maria de, Comentários à Lei de Introdução ao Código Civil, cit., v. 3, p. 205; VALLADÃO, Haroldo, Direito internacional privado, cit., v. 3, p. 187 et seq. Haroldo Valladão chega a afirmar que a sistemática adotada pela Consolidação das Leis da Justiça Federal superava a adotada nos Códigos de Portugal e Itália, bem como de outros países da Europa. 
no Brasil, mediante as condições que a lei brasileira fixar". Nada se alterou, portanto. Mantinham-se em vigor as disposições da Consolidação das Leis da Justiça Federal.

O Código de Processo Civil de 1939 também tratou da homologação da sentença estrangeira. A matéria vinha regulada no Título II do Livro VI. Enumerava alguns requisitos de homologabilidade, com as ressalvas da ofensa à soberania nacional, à ordem pública e aos bons costumes sem, contudo, modificar o sistema adotado pela Consolidação das Leis da Justiça Federal de 1898. Mantinha-se o sistema de delibação, vigente até então, intacto. ${ }^{135}$

Haroldo Valladão ${ }^{136}$ afirma que o reconhecimento da sentença estrangeira se dava, assim,

“[...] através dum processo, o da prévia homologação, rápido, com exame puramente formal da sentença, sem qualquer revisão de fundo, próximo do antigo giudizio di delibazioni da Itália, vendo-se apenas se a sentença reúne as condições de autenticidade, inteligibilidade, competência do tribunal, citação regular do réu, força de coisa julgada, não ofensa à ordem pública"

Em 1942, o Decreto-Lei n. 4.657 entrou em vigor, com as disposições da Lei de Introdução ao Código Civil que hoje, por força da Lei n. 12.376 de 30 de dezembro de 2010, é denominada Lei de Introdução às Normas do Direito Brasileiro, estabelecendo em seu artigo 15 os requisitos para a homologação. Revogava, quanto a esse ponto, o disposto no Código de Processo Civil então vigente. O seu parágrafo único trazia a novidade. Deixava expresso, novamente, que não dependiam de homologação as sentenças estrangeiras declaratórias do estado das pessoas.

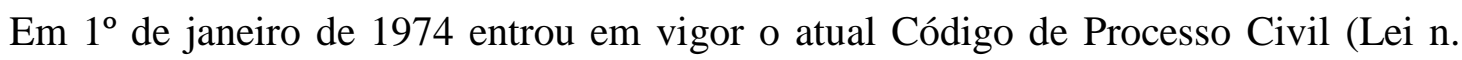
5.869, de 11.01.1973), que se absteve de regular a matéria, delegando sua disciplina, por meio dos artigos 483 e $484^{137}$, ao Regimento Interno do Supremo Tribunal Federal. Incluíram-se então no Regimento Interno do Supremo Tribunal Federal, de 18 de junho de 1970, as disposições sobre o tema nos artigos 210 a 217 que depois, a partir de $1^{\circ}$ de dezembro de

\footnotetext{
${ }^{135}$ GRECO FILHO, Vicente, Homologação de sentença estrangeira, cit., p. 48.

${ }^{136}$ VALLADÃO, Haroldo, Direito internacional privado, cit., v. 3, p. 187.

137 “Art. 483 - A sentença proferida por tribunal estrangeiro não terá eficácia no Brasil senão depois de homologada pelo Supremo Tribunal Federal. Parágrafo único - A homologação obedecerá ao que dispuser o Regimento Interno do Supremo Tribunal Federal. Art. 484 - A execução far-se-á por carta de sentença extraída dos autos da homologação e obedecerá às regras estabelecidas para a execução da sentença nacional da mesma natureza."
} 
1980, foi tratado nos artigos 215 a 224. Haroldo Valladão ${ }^{138}$ afirma que o legislador incorreu no despropósito de remeter o tratamento da matéria ao Regimento Interno do Supremo Tribunal Federal, pois se trata de matéria abrangida pelo direito internacional privado, regulada nos artigos 15 e 17 da hoje Lei de Introdução às Normas do Direito Brasileiro.

Segundo o autor, caberia ao Supremo Tribunal Federal, em decorrência do artigo 120, parágrafo único, "c", da Constituição Federal de 1967, com a redação da Emenda Constitucional n. 1 de 1969, regular o procedimento a ser observado no processamento da ação de homologação, que não deveria abarcar os requisitos para que a sentença fosse homologável, nem os efeitos da sentença estrangeira antes e depois de homologada, tendo em vista que não afeta à área processual e constitucional. ${ }^{139}$

Barbosa Moreira ${ }^{140}$ chegou a afirmar que o Supremo teria excedido "os limites constitucionais de sua competência normativa", na medida que o artigo 120, parágrafo único, letra "c", com a redação que lhe havia dado a Emenda Constitucional, apenas se referia a "processo e julgamento".

Em que pesem as críticas, com as quais concordamos, fato é que o Regimento Interno do Supremo Tribunal Federal tratava da matéria nos artigos 210 a 217 e depois nos artigos 215 a 224, cujo conteúdo era formado basicamente pelas regras contidas na hoje Lei de Introdução às Normas do Direito Brasileiro e no Código de Processo de 1939, com a transferência da competência para a homologação do Tribunal Pleno para o Presidente da Corte, em razão da Emenda Constitucional n. 7, de 13 de abril de $1977^{141}$. As disposições que regiam, portanto, o reconhecimento e a execução das sentenças estrangeiras encontravam-se nos artigos 15 e 17 da hoje Lei de Introdução às Normas do Direito Brasileiro e no Regimento Interno do Supremo Tribunal Federal.

A competência privativa do Supremo Tribunal Federal para homologar sentenças estrangeiras, desde que introduzida pela Lei n. 221, de 20 de novembro 1894, manteve-se

\footnotetext{
138 VALLADÃO, Haroldo, Direito internacional privado, cit., v. 3, p. 188-189. Também nesse sentido: MOREIRA, José Carlos Barbosa, Comentários ao Código de Processo Civil, cit., v. 5, p. 58-59.

139 VALLADÃO, Haroldo, op. cit., v. 3, p. 188-189. Também nesse sentido: GRECO FILHO, Vicente, Homologação de sentença estrangeira, cit., p. 49.

${ }^{140}$ MOREIRA, José Carlos Barbosa, op. cit., v. 5, p. 58-59.

${ }^{141}$ GRECO FILHO, Vicente, op. cit., p. 49; VALLADÃO, Haroldo, op. cit., v. 3, p. 204.
} 
intacta nas Constituições Federais de 1934 (art. 76, I, “g”), de 1937 (artigo 101, I, “f”), de 1946 (artigo 101, I, “g”), de 1967 (art. 114, I, “g”), na Emenda Constitucional n. 1 de 1969 (art. 119, I, “g”) e na de 1988 (art. 102, I, “h”), até a entrada em vigor da Emenda Constitucional n. 45, em 31/12/2004, que retirou do Supremo Tribunal Federal e atribuiu ao Superior Tribunal de Justiça (art. 105, I, “i”) a competência originária para processar e julgar a ação de homologação de sentenças estrangeiras e a concessão do exequatur às cartas rogatórias.

Em decorrência da Emenda Constitucional n. 45/2004, tornou-se necessário que o Superior Tribunal de Justiça fizesse uma alteração no seu regimento interno, com o fito de adaptá-lo às novas competências da Corte. Enquanto não aprovadas as disposições regimentais próprias, foram aplicadas as constantes do Regimento Interno do Supremo Tribunal Federal, conforme a Resolução n. 22, de 31 de dezembro de 2004, do Presidente do Superior Tribunal de Justiça. ${ }^{142}$

No entanto, antes mesmo das alterações do regimento interno, que ainda não sobrevieram, foi promulgada a Resolução n. 9, de 4 de maio de 2005, que disciplinou a matéria no âmbito do Superior Tribunal de Justiça, regulando o procedimento da ação de homologação de sentença estrangeira, bem como versando sobre requisitos, efeitos e limites à defesa, entre outros pontos. A partir de então, os artigos do Regimento Interno do Supremo Tribunal Federal que disciplinavam a homologação de sentença estrangeira não mais foram aplicados, de modo que, atualmente, as regras a serem observadas para o reconhecimento da sentença estrangeira encontram-se nos artigos 15 e 17 da Lei de Introdução às Normas do Direito Brasileiro e na Resolução n. 9 do Superior Tribunal de Justiça.

A mesma crítica feita por Haroldo Valladão ao Código de Processo Civil quando, por meio dos seus artigos 483 e 484, o tratamento da matéria foi remetido ao Regimento Interno do Supremo Tribunal Federal, permanece atual. A Resolução n. 9 do Superior Tribunal de Justiça, além de regular internamente o modo de processamento da ação de homologação de

\footnotetext{
${ }^{142}$ A Resolução n. 22 dispunha: “Art. $1^{\text {o }}$ - A homologação das sentenças estrangeiras e a concessão do exequatur às cartas rogatórias, introduzidas pela Emenda Constitucional n. 45/2004 mediante o acréscimo da alínea 'i' ao inciso I do art. 105, observarão, em caráter excepcional, até que o Superior Tribunal de Justiça aprove as disposições regimentais próprias, o que dispõe a respeito da matéria o Regimento Interno do Supremo Tribunal Federal nos artigos 215 a 229."
} 
sentença estrangeira, trata dos requisitos e efeitos da sentença estrangeira, elencando em seus $\operatorname{artigos} 5^{\circ}$ e $6^{\circ}$ verdadeiros pressupostos de homologabilidade.

A nosso sentir, os pressupostos, requisitos e efeitos da sentença estrangeira antes e depois de homologada são matérias típicas de direito internacional privado e por ele devem ser tratadas, como o são nos artigos 15 e 17 da Lei de Introdução às Normas do Direito Brasileiro. No entanto, não é isso que tem ocorrido desde que o Supremo Tribunal Federal passou a tratar do tema em seu regimento interno exacerbando dos limites de sua competência normativa. A situação se repete com a Resolução n. 9 do Superior Tribunal de Justiça. ${ }^{143}$

Quanto aos requisitos a serem observados para homologação, no entanto, apoiandonos em Barbosa Moreira ${ }^{144}$, entendemos em vigor as normas contidas nos artigos 15 e 17 da Lei de Introdução às Normas do Direito Brasileiro, pois tanto quanto as disposições do Regimento Interno do Supremo Tribunal Federal não possuíam o condão de revogar as normas da Lei de Introdução ao Código Civil, as disposições constantes da Resolução n. 9 também não o detêm.

Como já esclarecido em mais de uma oportunidade no decorrer deste trabalho, encontra-se em tramitação no Congresso Nacional o Projeto de Lei do Senado n. 166/2010, que trata do novo Código de Processo Civil. No entanto, a redação original, tal como proposta no artigo 878 , parágrafo único ${ }^{145}$, cópia fiel do artigo 483, parágrafo único, do Código de Processo Civil vigente, frustra quaisquer expectativas de alteração da sistemática vigente, na medida que determina seja observado, para a homologação de sentença estrangeira, ao quanto disposto no Regimento Interno do Superior Tribunal de Justiça. Nada obstante, o artigo $881^{146}$ do projeto de lei repete as disposições constantes nos artigos $5^{\circ}$ e $6^{\circ}$ da Resolução n. 9 do Superior Tribunal de Justiça, mesclados ao quanto disposto nos artigos 15 e 17 da Lei de Introdução às Normas do Direito Brasileiro.

\footnotetext{
${ }^{143}$ No mesmo sentido: MOREIRA, José Carlos Barbosa, Comentários ao Código de Processo Civil, cit., v. 5, p. 59-60.

${ }^{144}$ Ibidem, mesmas páginas.

145 “Art. 878 - A homologação de decisões estrangeiras será requerida por carta rogatória ou por ação de homologação de sentença estrangeira. Parágrafo único - A homologação obedecerá ao que dispuser o Regimento Interno do Superior Tribunal de Justiça."

146 “Art. 881 - Constituem requisitos indispensáveis à homologação da decisão: I - ser proferida por autoridade competente; II - ser precedida de citação regular, ainda que verificada a revelia; III - ser eficaz no país em que foi proferida; IV - estar autenticada pelo cônsul brasileiro e acompanhada de tradução oficial; V - não haver manifesta ofensa à ordem pública."
} 
Importante registrar que pouca importância prática deverá haver, tendo em vista que as disposições da Resolução n. 9 do Superior Tribunal de Justiça, do projeto do novo Código de Processo Civil e da Lei de Introdução às Normas do Direito Brasileiro pouco se diferenciam quanto aos requisitos exigidos para a homologação da sentença estrangeira.

Entretanto, em mais uma oportunidade, o legislador incorrerá em incongruência técnica ou mesmo científica, ao remeter o tratamento da matéria ao Regimento Interno do Superior Tribunal de Justiça e, ao mesmo tempo, por meio de cópia mal feita dos requisitos contidos nos artigos 15 e 17 da Lei de Introdução às Normas do Direito Brasileiro, estabelecer no referido artigo 881 requisitos para a homologação da sentença estrangeira, ao invés de delegar a matéria para as normas contidas na Lei de Introdução às Normas do Direito Brasileiro.

$\mathrm{Na}$ medida que o tema de reconhecimento de sentença estrangeira encontra-se inserido na questão da cooperação jurídica internacional, deixamos registrado que o Ministério da Justiça designou uma comissão para elaborar um anteprojeto de Lei de Cooperação Jurídica Internacional, por meio da Portaria n. 2.199, publicada no Diário Oficial de 11/08/2004.

A comissão é composta por Claudia Maria Chagas, Antenor Pereira Madruga, Athos Gusmão Carneiro, Carmem Beatriz de Lemos Tiburcio, Edson de Oliveira Almeida, Gilson Dipp, Manoel Gomes Pereira, Marcio Pereira Pinto Garcia, Milton Nunes Toledo Jr., Walter Nunes da Silva Jr. e Nadia de Araujo. Nadia de Araujo ${ }^{147}$ noticia que a comissão já finalizou seus trabalhos, aguardando sua remessa ao Congresso Nacional. Para a autora, a nova legislação será mecanismo importante para a cooperação jurídica internacional e contribuirá para a efetividade das decisões civis em processos internacionais, entre outros pontos relevantes. Registra ainda que o projeto de lei foi utilizado como fonte para a elaboração das regras da Resolução n. 9 relativas à homologação de sentenças estrangeiras e cumprimento de cartas rogatórias.

\footnotetext{
147 ARAUJO, Nadia de (Coord.). Cooperação jurídica internacional no Superior Tribunal de Justiça: comentários à Resolução n. 9/2005. Rio de Janeiro: Renovar, 2010. p. 14-15.
} 
Registramos que o Código Bustamante elege o sistema de delibação em seu artigo $423^{148}$, do que se conclui que seus requisitos são compatíveis com a lei brasileira.

\subsection{Natureza jurídica da sentença estrangeira}

Sem entrarmos no debate sobre o conceito de sentença, Pontes de Miranda a define como toda decisão suscetível de extinguir a relação jurídica processual ${ }^{149}$. No entanto, para que possamos estabelecer um conceito material de sentença, entendemos ainda necessário que ela decida a controvérsia com força de coisa julgada material e emane de um processo em que foram respeitados os princípios básicos do contraditório ${ }^{150} \mathrm{e}$, com base nos ensinamentos de Serpa Lopes ${ }^{151}$, acrescentamos também que para ser sentença, ou mesmo para que ela exista como tal, ela deva decorrer de uma atividade jurisdicional de órgãos realmente portadores de autoridade judiciária conferida pelo Estado soberano.

Como já visto, o poder jurisdicional é uma das mais características manifestações de soberania, de modo que qualquer decisão que não emane de um órgão revestido de jurisdição por um Estado soberano não deve ser conceituada como sentença, sob pena de se incorrer em incongruência terminológica, o que pode desvirtuar-lhe o significado e acarretar equívocos legislativos, com consequências práticas negativas.

Serpa Lopes ${ }^{152}$ com exatidão professa que a característica estrangeira da sentença decorre do órgão judicante de onde ela emana. Pondera que "desde que o órgão judicante não recebe a sua jurisdição da mesma soberania, desde que a sentença é proferida por um juiz ou

\footnotetext{
148 “Art. 423 - Toda sentença civil ou contencioso administrativa, proferida em um dos Estados contractantes, terá força e poderá executar-se nos demais, se reunir as seguintes condições: 1. Que o juiz ou tribunal que a tiver pronunciado tenha competencia para conhecer do assumpto e julgá-lo, de accôrdo com as regras deste Codigo; 2. Que as partes tenham sido citadas pessoalmente ou por seu representante legal, para a ação; 3. Que a sentença não offenda a ordem publica ou o direito publico do paiz onde deva ser executada; 4 . Que seja executoria no Estado em que tiver sido proferida; 5. Que seja traduzida autorizadamente por um funccionario ou interprete official do Estado em que se há de executar, se ahi fôr differente o idioma empregado; 6. Que o documento que a contém reuna os requisitos para ser considerado como authentico no Estado de que proceda, e os exigidos, para que faça fé, pela legislação do Estado onde se pretende que a sentença seja cumprida."

${ }^{149}$ PONTES DE MIRANDA, Francisco Cavalcanti, Ação recisória, p. 38, apud SERPA LOPES, Miguel Maria de, Comentários à Lei de Introdução ao Código Civil, cit., v. 3, p. 206, nota 1 .

${ }^{150}$ GRECO FILHO, Vicente, Homologação de sentença estrangeira, cit., p. 124. É sobre esse aspecto que nos interessa a sentença, uma vez que é a sentença que resolve materialmente a demanda a ser submetida ao reconhecimento.

${ }^{151}$ SERPA LOPES, Miguel Maria de, op. cit., p. 207.

152 Ibidem, mesma página.
} 
tribunal ligado a um Estado estrangeiro, estrangeira é esta sentença. É a decisão emanada de uma soberania estrangeira". E conclui com perfeição: "Cumpre, assim, para a existência de uma sentença estrangeira, que ela decorra de uma atividade jurisdicional, de órgãos realmente portadores de autoridade judiciária conferida pelo Estado estrangeiro." ${ }^{153}$

Definido basicamente o que seja uma sentença estrangeira, cumpre esclarecer qual a sua natureza, antes de submetida ao processo de homologação. Convém, no entanto, fazer algumas considerações a respeito do que já foi dito no Capítulo I, para melhor elucidar o tema.

Partindo da premissa de que a avocação da jurisdição é ato de soberania, cada governo tanto pode organizar livremente seu direito, como pode estender ou retrair os limites de sua função jurisdicional, o fazendo em observância ao princípio da efetividade, segundo o qual o Estado deve avocar como seu o poder de dizer o direito somente nas causas em que puder efetivar sua decisão ${ }^{154}$. Surgem então, como visto, as regras que limitam o alcance da jurisdição nacional, denominadas, equivocadamente, regras de competência internacional.

A conveniência política dessa limitação tem como pressuposto lógico a aceitação de que há causas que devem ser submetidas ao poder jurisdicional de Estado portador de soberania de igual dignidade. Em outras palavras, o ato de limitar sua jurisdição decorre da admissão de que a outro poder jurisdicional deva ser submetida a demanda, cujo pressuposto é a aceitação lógica de que há outras soberanias tão dignas quanto a sua, pois caso assim não fosse, avocaria com exclusividade o poder jurisdicional em relação a todas as causas que pudessem, porventura, lhe interessar. Se limita a sua jurisdição, é porque reconhece como legítimo o poder jurisdicional exercido por outros Estados igualmente soberanos. ${ }^{155}$

Tal conduta implica necessariamente em reconhecer que os atos jurisdicionais de outros Estados igualmente soberanos são tão eficazes quanto os próprios, o que impõe considerar a sentença estrangeira como verdadeira sentença proveniente de um poder

\footnotetext{
${ }^{153}$ SERPA LOPES, Miguel Maria de, Comentários à Lei de Introdução ao Código Civil, cit., v. 3, p. 207.

${ }^{154}$ CASTRO, Amílcar de, Direito internacional privado, cit., p. 537-540; GRECO FILHO, Vicente, Homologação de sentença estrangeira, cit., p. 64; HUCK, Hermes Marcelo, Sentença estrangeira e lex mercatoria: horizontes e fronteiras do comércio internacional, cit., p. 5; SANTOS, Moacyr Amaral, Primeiras linhas de direito processual civil, cit., v. 1, p. 199; TENÓRIO, Oscar Accioly, Lei de Introdução ao Código Civil Brasileiro: Decreto-Lei n. 4.657, de 4 de setembro de 1942, cit., p. 380, § 716.

${ }^{155}$ GRECO FILHO, Vicente, op. cit., p. 89.
} 
jurisdicional soberano, ou seja, a sentença estrangeira como um ato jurisdicional dotado de seus efeitos inerentes. ${ }^{156}$

É a sentença, seja ela nacional ou estrangeira, que realiza, com exclusividade, o juízo lógico que resolve o conflito de direito material, de modo que a relação substancial litigiosa constitui seu objeto e nela se exaure. Estabelece, assim, a disciplina jurídica concreta e definitiva da demanda que produz efeitos e, desse modo, deve ser respeitada. Se o processo no exterior é verdadeiro processo, a sentença estrangeira é verdadeira sentença, ato jurisdicional dotado de eficácia de sentença. Tem-se assim que os efeitos decorrentes da sua imutabilidade lhe são inerentes. ${ }^{157}$

Mister neste ponto estabelecer, como dito acima, que a eficácia imperativa, eficácia de coisa julgada, lhe é inerente. É o que procuraremos demonstrar sem, contudo, adentrar no terreno da natureza jurídica da coisa julgada.

Serpa Lopes ${ }^{158}$ com clareza distingue a eficácia executiva da sentença de sua eficácia imperativa, de coisa julgada. Afirma que a sentença possui uma eficácia interna, relacionada à força executória decorrente do comando emergente da sentença, a qual subordina os litigantes, surgindo para eles uma obrigação, e uma eficácia externa, como sendo a decorrente da força da sentença como valor de coisa julgada. Afirma que essa eficácia externa independe de qualquer conduta das partes, para que os efeitos suscetíveis de se produzir um ato jurídico se realizem.

Após, esclarece que se pode invocar uma sentença ora para a eficácia de coisa julgada, ora para executar um seu comando, explicando que são completamente distintas essas duas eficácias, sendo a eficácia de coisa julgada inerente à sentença estrangeira. ${ }^{159}$

\footnotetext{
${ }^{156}$ GRECO FILHO, Vicente, Homologação de sentença estrangeira, cit., p. 89; HUCK, Hermes Marcelo, Sentença estrangeira e lex mercatoria: horizontes e fronteiras do comércio internacional, cit., p. 24-25; SERPA LOPES, Miguel Maria de, Comentários à Lei de Introdução ao Código Civil, cit., v. 3, p. 207.

${ }^{157}$ GRECO FILHO, Vicente, op. cit., p. 99-100; SERPA LOPES, Miguel Maria de, op. cit., p. 216-217.

${ }^{158}$ SERPA LOPES, Miguel Maria de, op. cit., p. 208-209. O autor pondera ainda que haveria um terceiro tipo de eficácia, o da sentença com valor probante. No mesmo sentido: GRECO FILHO, Vicente, op. cit., p. 99.

${ }^{159}$ SERPA LOPES, Miguel Maria de, op. cit., p. 218 e 219. No mesmo sentido: GRECO FILHO, Vicente, op. cit., p. 100.
} 
Oportuno colacionar os ensinamentos de Celso Neves ${ }^{160}$, que também nos levam à conclusão de que a eficácia executiva é distinta da eficácia imperativa, esta última decorrente da autoridade de coisa julgada. Após esclarecer que a sentença realiza o juízo lógico que resolve o conflito de direito material, definindo o comando concreto que impera sobre as partes, pondera com relação às sentenças condenatórias:

"Exauridos os meios que o processo põe à disposição dos litigantes, para
garantir que a decisão seja exata, adquire ela a autoridade de coisa julgada,
tornando-se legalmente indiscutível. Encerra-se, aí, o primeiro momento da
atividade jurisdicional, no plano do processo de cognição. Resolvido o
problema da certeza do direito, continua em aberto o problema de sua
realização prática que, ou se dá voluntariamente, pela submissão do obrigado
ao comando emergente da decisão, ou pode ser obtida, coercitivamente,
através da execução forçada."

Dessa lição podemos extrair que a eficácia da coisa julgada atinge o conteúdo declaratório da certeza do direito e a execução, em casos de sentenças condenatórias, dá-se por meio de um processo próprio posterior à declaração jurisdicional da certeza do direito. A eficácia executiva decorre da declaração da certeza do direito, vez que ela integra a própria sentença. Como bem esclarece Serpa Lopes ${ }^{161}$ " "são setores distintos no tempo e no espaço".

Parece-nos nítido, portanto, que perfeitamente separáveis o conteúdo declaratório de certeza do direito sobre a qual recai a autoridade de coisa julgada e a eficácia executiva, sendo que nas sentenças em que não há condenação, a eficácia imperativa da coisa julgada permanece, não sendo necessária mais nenhuma providência jurisdicional para que sua eficácia se realize, o que a torna indissociável da própria sentença, equivalendo mesmo, essa eficácia imperativa, à própria autoridade de eficácia jurídica de qualquer sentença. ${ }^{162}$

A sentença estrangeira só pode ser considerada como verdadeira sentença se lhe for atribuída de forma indissociável a eficácia imperativa, sem a qual o ato jurisdicional em questão não seria sentença. Mostra-se imperioso, desse modo, reconhecer a eficácia imperativa da sentença como parte integrante do próprio conceito de sentença, de modo que o reconhecimento ou declaração de existência da sentença já a pressupõem ${ }^{163}$. Disso resulta,

\footnotetext{
${ }^{160}$ NEVES, Celso. Coisa julgada civil. São Paulo: Revista dos Tribunais, 1971. p. 449 et seq.

${ }^{161}$ SERPA LOPES, Miguel Maria de, Comentários à Lei de Introdução ao Código Civil, cit., v. 3, p. 215.

162 GRECO FILHO, Vicente, Homologação de sentença estrangeira, cit., p. 99; SERPA LOPES, Miguel Maria de, op. cit., v. 3, p. 215 e 219.

${ }^{163}$ GRECO FILHO, Vicente, op. cit., p. 100 e 107.
} 
como veremos mais adiante, que nem toda eficácia da sentença estrangeira depende de uma constituição integrativa.

A natureza jurídica que se tem da sentença estrangeira condiciona inexoravelmente o processo de homologação de sentença estrangeira, na medida que, nos dizeres de Vicente Greco ${ }^{164}$, "se o processo é de homologação de sentença estrangeira, para que o ato alienígena sequer seja apreciado, é preciso que tenha eficácia sentencial, com força de coisa julgada”.

A eficácia da imutabilidade da declaração de certeza jurídica contida no ato sentencial existe, portanto, independentemente de qualquer ato jurisdicional do Estado que, porventura, a reconhecerá, pois nos parece incompreensível pretender reconhecer uma sentença que não exista como tal. $\mathrm{O}$ reconhecimento evidentemente pressupõe a realidade do desconhecido. ${ }^{165}$

A sua existência como sentença independe de qualquer providência jurisdicional do Estado em cujo território se buscará efetivação. Decorre do reconhecimento de que a outro poder jurisdicional de igual dignidade deva ser submetida a demanda. Esse reconhecimento político é feito previamente, como já esclarecido, e se revela na limitação da jurisdição.

Aceitar, portanto, que outras soberanias decidam uma lide que possa lhe interessar ${ }^{166}$ importa reconhecer que os atos jurisdicionais desses outros países são tão eficazes quanto os próprios, cabendo ao Estado, pelo seu Poder Judiciário, apenas a aferição de alguns mínimos requisitos, para que a sentença estrangeira produza aqui todos os seus efeitos.

E a isso atende o sistema de delibação, que tem como pressuposto lógico e jurídico a concepção de que a sentença estrangeira é verdadeira sentença, como será visto, de modo que para a realização plena de sua eficácia, impõe a observância de alguns mínimos requisitos, tais como se a sentença emanou de uma soberania; se ela é competente; se é ato jurisdicional, observados os requisitos processuais mínimos como, por exemplo, a citação válida; se não ofende aos bons costumes e à ordem pública, bem como se não invade a soberania. Qualquer exigência outra importaria em desconhecer, ainda que parcialmente, uma soberania alheia, ou

\footnotetext{
${ }^{164}$ GRECO FILHO, Vicente, Homologação de sentença estrangeira, cit., p. 100.

${ }^{165}$ CASTRO, Amílcar de, Direito internacional privado, cit., p. 53.

166 Evidente que nos casos de jurisdição concorrente, pois na exclusiva não se cogita de reconhecimento da sentença estrangeira.
} 
mesmo sua dignidade. Em outras palavras, o sistema de delibação concebe a sentença estrangeira como verdadeira sentença. ${ }^{167}$

No entanto, em decorrência da má compreensão do que de fato caracteriza uma sentença como estrangeira, de qual a natureza jurídica da sentença estrangeira antes de homologada e dos pressupostos lógicos do sistema de delibação, como se verá, bem como em razão do tratamento da matéria em diplomas legais que não a comportam, houve algumas incoerências sistemáticas e imprecisões nos textos legais. ${ }^{168}$

Consequência disso é que, em atenção à ficção criada pela Lei de Arbitragem (Lei 9.307/96) e à Resolução n. 9 do Superior Tribunal de Justiça, bem como em face do posicionamento já adotado anteriormente pelo Supremo Tribunal Federal, o conceito de sentença estrangeira tem sido interpretado de forma ampla e extensiva, de modo que, equivocadamente no nosso sentir, muito embora por imposição legal, têm sido consideradas sentenças estrangeiras decisões emanadas de órgão não jurisdicionais, tais como decisões administrativas ou arbitrais. ${ }^{169}$

\subsection{Sistema de delibação}

Historicamente, vários modelos de relacionamento de julgados peregrinos têm existido. Os sistemas legislativos variam de acordo com a maior ou menor permeabilidade que se dá às sentenças estrangeiras no ordenamento jurídico nacional. Leva-se em conta o tratamento conferido aos provimentos judiciais estrangeiros pelo ordenamento jurídico em que se busca a produção de efeitos da sentença estrangeira.

Assim, o relevante para o direito internacional é a medida dentro da qual um país facilita ou obsta esse reconhecimento. Nos dizeres de Amílcar de Castro ${ }^{170}$, "o que aconselha

\footnotetext{
${ }^{167}$ GRECO FILHO, Vicente, Homologação de sentença estrangeira, cit., p. 89-90; HUCK, Hermes Marcelo, Sentença estrangeira e lex mercatoria: horizontes e fronteiras do comércio internacional, cit., p. 43 et seq.; SERPA LOPES, Miguel Maria de, Comentários à Lei de Introdução ao Código Civil, cit., v. 3, p. 201 et seq.

${ }^{168}$ Vicente Greco afirma que em razão da má compreensão de que a sentença estrangeira é verdadeira sentença, mesmo nos países que adotaram o sistema de delibação, a doutrina e a jurisprudência chegaram a desvirtuarlhe o significado, contribuindo para a imprecisão dos textos legais e necessidade de integração doutrinária (Homologação de sentença estrangeira, cit., p. 88).

169 ARAUJO, Nadia de (Coord.), Cooperação jurídica internacional no Superior Tribunal de Justiça: comentários à Resolução n. 9/2005, cit., p. 25.

${ }^{170}$ CASTRO, Amílcar de, Direito internacional privado, cit., p. 272.
} 
o espírito internacional é revalidar, revigorar a apreciação feita pela jurisdição estrangeira". O que nos importa, portanto, neste momento, é determinar se, e em que medida, o Estado reconhecerá, em seu território, eficácia à sentença estrangeira.

Em que pese a dificuldade em se estabelecer uma classificação rigorosa de grupos de legislações, levando-se em conta o tratamento conferido aos julgados estrangeiros, podemos estabelecer ao menos três sistemas, conforme a doutrina. ${ }^{171}$

Há os sistemas nos quais se recusa a homologação, tidos também como sistemas de completo isolamento, os quais desconhecem o processo de execução de julgado estrangeiro. Nesses sistemas, podem-se agrupar ordens jurídicas refratárias ao reconhecimento da sentença estrangeira como ato jurisdicional. Essas ordens jurídicas não prescrevem o processo de homologação da sentença estrangeira, sendo a sentença estrangeira, para eles, um mero fato sem qualquer relevância jurisdicional, apenas com eficácia probatória documental, que atuará como elemento de convicção em nova demanda que o interessado se verá obrigado a propor. $^{172}$

Os sistemas de revisão de mérito ou revisão absoluta veem a sentença estrangeira como ato jurisdicional válido por si mesmo, contudo de eficácia mínima ou sem eficácia, vez que não lhe é atribuída a eficácia de coisa julgada. Condiciona-se toda a sua eficácia a uma revisão de mérito do julgado, cuja consequência é uma sentença nacional proferida em substituição, ou mesmo de aceitação, e que renova o ato estrangeiro. ${ }^{173}$

O fundamento para tal conduta é a necessidade de aferir se o tribunal estrangeiro procedeu com segurança e justiça. Pode-se dizer assim que há uma revisão ilimitada do

\footnotetext{
${ }^{171}$ MOREIRA, José Carlos Barbosa, Comentários ao Código de Processo Civil, cit., v. 5, p. 53; GRECO FILHO, Vicente, Homologação de sentença estrangeira, cit., p. 87-88; SERPA LOPES, Miguel Maria de, Comentários à Lei de Introdução ao Código Civil, cit., v. 3, p. 196-197; HUCK, Hermes Marcelo, Sentença estrangeira e lex mercatoria: horizontes e fronteiras do comércio internacional, cit., p. 23-24.

${ }^{172}$ MOREIRA, José Carlos Barbosa, op. cit., p. 53. GRECO FILHO, Vicente, op. cit., p. 87-88; HUCK, Hermes Marcelo, op. cit., p. 43 et seq.; SERPA LOPES, Miguel Maria de, op. cit., p. 196-198. Esse último autor, embora afirme haver algumas diferenças entre ordenamentos do mesmo grupo, pondera que sempre há necessidade de uma ação própria sobre o mesmo objeto da sentença estrangeira. A diferença se dá quanto ao valor que a ela é dado. Esclarece que tal é a situação da Holanda, Noruega, Suécia e Dinamarca, fazendo a ressalva de que no direito anglo-saxão, cujo maior expoente é a Inglaterra, se tende a reconhecer um maior valor ao julgado estrangeiro, com a noção de que há um direito adquirido a fundamentar a nova demanda.

173 MOREIRA, José Carlos Barbosa, op. cit., v. 5, p. 55; GRECO FILHO, Vicente, op. cit., p. 88; HUCK, Hermes Marcelo, op. cit., p. 45 et seq.; SERPA LOPES, Miguel Maria de, op.cit., p. 199-200.
} 
julgado estrangeiro, reconhecendo-o e, portanto, autorizando sua execução apenas quando se chega à conclusão, por meio de um provimento jurisdicional, de que foi justo. ${ }^{174}$

Há os sistemas de controle limitado, tidos também como de revisão parcial ou de delibação. Para eles, a sentença estrangeira é respeitada como verdadeiro ato jurisdicional portador de eficácia sentencial. Afere-se se a sentença peregrina preenche determinados requisitos, intrínsecos e extrínsecos, elencados como suficientes para que se reconheça sua eficácia. A liberação de seus efeitos fica, assim, subordinada ao controle exercido por um órgão judiciário nacional, sem que haja revisão de fundo do julgado estrangeiro. ${ }^{175}$

Pode haver variação quanto à necessidade desse controle para a produção de quaisquer efeitos do julgado estrangeiro, ou se somente necessário para autorizar sua execução. No entanto, tal questão será enfrentada mais à frente.

Serpa Lopes ${ }^{176}$, ao abordar com extrema lucidez esse sistema de delibação, revisão parcial ou controle limitado, professa que "no sistema de controle limitado, a força inerente à sentença estrangeira não é condicionada senão ao preenchimento de determinados requisitos, reputados como essenciais para que o poder soberano do Estado consinta na sua executoriedade dentro do seu território".

Importante tecermos algumas considerações sobre a afirmação que acima fizemos de que, para esse sistema, a sentença estrangeira é respeitada como verdadeiro ato jurisdicional portador de eficácia sentencial.

Como já dissemos alhures, ao limitar a extensão da jurisdição, o Estado reconhece que a outros Estados deva ser submetida a composição de determinadas lides. E se assim o faz, é porque reconhece como igualmente legítimo o poder jurisdicional desse outro Estado, cujos provimentos jurisdicionais haverão de ser tão eficazes quanto os seus, o que implica em

\footnotetext{
${ }^{174}$ MOREIRA, José Carlos Barbosa, Comentários ao Código de Processo Civil, cit., v. 5, p. 55; GRECO FILHO, Vicente, Homologação de sentença estrangeira, cit., p. 88. HUCK, Hermes Marcelo, Sentença estrangeira e lex mercatoria: horizontes e fronteiras do comércio internacional, cit., p. 45 et seq.; SERPA LOPES, Miguel Maria de, Comentários à Lei de Introdução ao Código Civil, cit., v. 3, p. 199-200. Barbosa Moreira e Serpa Lopes afirmam que essa era a situação da França até 1964.

${ }^{175}$ MOREIRA, José Carlos Barbosa, op. cit., p. 55; GRECO FILHO, Vicente, op. cit., p. 91-92. HUCK, Hermes Marcelo, op. cit., p. 23-24; SERPA LOPES, Miguel Maria de, op. cit., p. 226-227.

${ }^{176}$ SERPA LOPES, Miguel Maria de, op. cit., p. 200. No mesmo sentido: GRECO FILHO, Vicente, op. cit., p. 88.
} 
última análise reconhecer na sentença estrangeira uma verdadeira sentença dotada da eficácia declaratória imperativa, sem a qual o ato não seria sentença. ${ }^{177}$

O reconhecimento, portanto, de que há outras soberanias tão dignas quanto a sua, aceitando que outro poder jurisdicional resolva o litígio por meio de uma sentença, revela-se como substrato lógico e jurídico para a existência do sistema de delibação. Em outras palavras, essa concepção da sentença estrangeira como ato jurisdicional perfeito é pressuposto lógico de existência do sistema de delibação. ${ }^{178}$

Ora, se assim não fosse, como bem pondera Vicente Greco Filho ${ }^{179}$, seria um verdadeiro absurdo, pois "teria por objeto um ato que deva ser sentença, mas ele próprio atribuiria essa qualidade. É o senso comum jurídico que também nos diz que o processo é de ‘homologação' e não de criação da sentença que, aliás, lhe serve de pressuposto".

Se, portanto, o que se busca por meio da delibação é o reconhecimento da sentença estrangeira, para que ela seja apreciada, é preciso que exista como tal, ou seja, tenha eficácia sentencial com força de coisa julgada. A sua existência como sentença, portanto, não depende de nenhuma providência jurisdicional, vez que decorre do reconhecimento da existência de outras soberanias no plano político, que se revela na limitação da jurisdição.

Essa concepção traz algumas consequências.

A primeira delas é que os efeitos da sentença estrangeira, ou mesmo sua força, em nada são alterados ou modificados pela homologação. Em outras palavras, a eficácia sentencial não é dada pelo processo de homologação, mas decorre da própria sentença, porque a sentença preexistia ao processo de homologação e dele independe. ${ }^{180}$

Segundo é que limita-se o controle feito pelo Poder Judiciário a requisitos mínimos e taxativos, cujo objetivo é atestar a regularidade do ato (sentença), de modo que a sentença

\footnotetext{
177 GRECO FILHO, Vicente, Homologação de sentença estrangeira, cit., p. 88-90.

${ }^{178}$ Ibidem, mesmas páginas.

${ }^{179}$ Ibidem, p. 101.

${ }^{180}$ Ibidem, p. 91.
} 
estrangeira haverá de ser reconhecida, uma vez atestados os requisitos compatíveis com o exame de delibação. ${ }^{181}$

E, terceiro, que o sistema de delibação mostra-se compatível tanto com o reconhecimento incidental da sentença, como com um processo formal voltado exclusivamente para a homologação. ${ }^{182}$

Isso ocorre porque o sistema de delibação não se revela na forma ou modo pelo qual a sentença estrangeira é reconhecida, mas nos requisitos exigidos para o seu reconhecimento. E são esses requisitos que revelam a concepção de determinado ordenamento jurídico sobre a natureza da sentença estrangeira antes de homologada. ${ }^{183}$

Tanto assim que no Brasil admitiu-se o reconhecimento e a exequibilidade das sentenças estrangeiras por um juízo declaratório incidental, pelo qual se aferiam os requisitos do sistema de delibação, sistema do "cumpra-se" estatuído pelo Decreto n. 6.982 de 1878; atualmente, decorre de um processo formal de homologação de competência do Superior Tribunal de Justiça, com precípua finalidade de aferir os mesmos requisitos instituídos pela Lei n. 221 de $1894 .^{184}$

Nota-se, com isso, a compatibilidade do sistema de delibação tanto com um juízo formal de homologação, quanto com um modo incidental de aferição dos mesmos requisitos. Na realidade, como bem pondera Haroldo Valladão ${ }^{185}$, o modo de processar é regramento de como proceder do tribunal e nada interfere nos requisitos a serem adotados pelo ordenamento jurídico nacional para aferir a regularidade do ato sentencial estrangeiro. Deve, sim, estar amoldado a esses requisitos, ou seja, diante da existência deles, estabelecer o melhor modo de aferi-los.

Por esse motivo, não deveriam tratar dos requisitos a Resolução n. 9 do Superior Tribunal de Justiça e tampouco o novo Código de Processo (art. 881 do Projeto de Lei do

\footnotetext{
${ }^{181}$ GRECO FILHO, Vicente, Homologação de sentença estrangeira, cit., p. 91.

182 Ibidem, mesma página.

${ }^{183}$ Ibidem, mesma página..

184 Atualmente, os Códigos argentino (art. 519) e grego (art. 323) admitem um juízo incidental de delibação. Vide: MOREIRA, José Carlos Barbosa, Comentários ao Código de Processo Civil, cit., v. 5, p. 54.

${ }^{185}$ VALLADÃO, Haroldo, Direito internacional privado, cit., v. 3, p. 123.
} 
Senado n. 166/2010). Esses regramentos deveriam se limitar ao modo de processamento, porque os requisitos já se encontram estabelecidos na Lei de Introdução às Normas do Direito Brasileiro, que é coerente com a sistemática do sistema de delibação adotado entre nós desde o Decreto n. 6.982 de 1878.

Concordamos com Vicente Greco Filho, ao afirmar que os requisitos que atendem ao sistema de delibação, que pressupõe a sentença estrangeira como verdadeira sentença, devem ser mínimos e relativos a "se emanou de soberania; se esta soberania é competente; se é ato jurisdicional, incluído, aqui, o exame dos requisitos essenciais do processo que gera a sentença, como, por exemplo, a citação válida; e se não invade a própria soberania e os princípios essenciais que consagra como a ordem pública e os bons costumes". ${ }^{186}$

E são esses requisitos os previsto nos artigos 15 e 17 da Lei de Introdução às Normas do Direito Brasileiro. Assim, também, o Código Bustamante, vigente entre nós, que elege o sistema de delibação em seu artigo 423, cujos requisitos quase equivalem aos da lei brasileira.

O sistema de delibação, portanto, limita a atividade cognitiva do órgão jurisdicional a poucos e taxativos requisitos, com o objetivo precípuo de atestar a regularidade da sentença estrangeira decorrente de um poder jurisdicional, de modo a permitir a plena produção de efeitos em território distinto da que foi prolatada. No nosso entendimento, acrescemos, só autorizar o início da execução da sentença estrangeira.

Pode-se dizer, assim, que o sistema de delibação é o sistema voltado ao reconhecimento de sentença decorrente de poder jurisdicional estrangeiro mais adequado ao espírito internacionalista mencionado por Amílcar de Castro ${ }^{187}$ e que revela a concepção que dado ordenamento jurídico possui em relação ao ato jurisdicional a ser reconhecido.

Por isso mesmo, Vicente Greco Filho ${ }^{188}$, em sua esclarecedora obra sobre a homologação de sentenças estrangeiras, demonstrando a coerência a ser seguida pelos sistemas legislativos que adotam o sistema de delibação, chega a dizer que "a natureza

\footnotetext{
186 GRECO FILHO, Vicente, Homologação de sentença estrangeira, cit., p. 89. Importante notar que esses requisitos são os mesmos estabelecidos nos artigos 15 e 17 da Lei de Introdução às Normas do Direito Brasileiro.

${ }^{187}$ CASTRO, Amílcar de, Direito internacional privado, cit., p. 272.

${ }^{188}$ GRECO FILHO, Vicente, op. cit., p. 87.
} 
jurídica da figura depende diretamente do sistema adotado para sua aceitação, porquanto é destituída de sentido a teoria que não encontra embasamento na sistemática vigente em determinado lugar em determinada época".

Como já esclarecido, o precursor na adoção do sistema de delibação foi o Código de Processo Civil italiano de 1865 e, diante do exposto, é lícito dizer que é o sistema entre nós adotado desde o Decreto n. 6.982 de 1878, com a ressalva do requisito da reciprocidade, logo depois atenuado pela Lei n. 221 de 1894.

\subsection{Natureza do processo de homologação}

Instituído entre nós desde 1878, o juízo de delibação da sentença estrangeira passou a ser realizado por meio de um processo formal de homologação, com o advento da Lei n. 221 de 1894, atualmente de competência do Superior Tribunal de Justiça, instituído unicamente para o fim de se aferirem os requisitos compatíveis com o sistema de delibação. Indiscutível, portanto, que a homologação da sentença estrangeira se dá através de um processo inequivocamente moldado ao sistema de delibação e, portanto, cujas bases se assentam nas mesmas premissas.

Como esclarecido em mais de uma oportunidade, o sistema de delibação decorre diretamente do reconhecimento de que há outras soberanias de igual dignidade, realizado por avaliação política materializada na limitação da jurisdição. De modo que esse reconhecimento, de forma alguma, é refeito ou sequer renovado no momento do juízo de delibação realizado no processo de homologação. É, antes de tudo, substrato lógico-jurídico de sua existência. ${ }^{189}$

O juiz nacional, ao avaliar os requisitos impostos pela lei, evidentemente não faz exame da soberania de outro país e, tampouco, da própria, de modo que a homologação de sentença estrangeira se mostra, de forma inequívoca, providência de natureza jurisdicional, e não administrativa. ${ }^{190}$

\footnotetext{
${ }^{189}$ GRECO FILHO, Vicente, Homologação de sentença estrangeira, cit., p. 90.

190 ARAUJO, Nadia de. Direito internacional privado: teoria e prática brasileira. 5. ed. Rio de Janeiro: Renovar, 2011. p. 329; MOREIRA, José Carlos Barbosa, Comentários ao Código de Processo Civil, cit., v. 5, p. 83-84; FUX, Luís. Homologação de sentença estrangeira. In: TIBURCIO, Carmen; BARROSO, Luís Roberto (Orgs.). Direito internacional contemporâneo. Rio de Janeiro: Renovar, 2006. p. 643 et seq.; GRECO FILHO, Vicente,
} 
O processo de homologação cuida de compor uma lide. Naturalmente, aquele que pretende homologar em território nacional uma sentença estrangeira deseja que lhe seja atribuída a eficácia faltante. E a isso se opõe o interessado, que não deseja ver a sentença estrangeira produzir seu efeito executivo em território diverso da que foi prolatada. Revela-se aí o conflito de interesse qualificado por uma pretensão resistida, qual seja, a de ver a sentença estrangeira com toda a sua eficácia. ${ }^{191}$

Por meio da sentença de homologação, uma vez constatada a presença dos requisitos legais, declara-se o direito ao reconhecimento da decisão proferida em território estrangeiro, autorizando a produção da eficácia que lhe falta. Para a produção desse efeito, a sentença nacional de homologação revela-se como condição necessária a integrar a sentença homologanda.

Esclarecida sua natureza jurisdicional, cumpre avaliar se de natureza declaratória, constitutiva e executiva. Dúvida não resta na doutrina quanto à providencia decorrente do processo de homologação ser constitutiva. A homologação atua como pressuposto de eficácia para a sentença estrangeira. A sentença de homologação integra à sentença estrangeira a eficácia que lhe falta em território nacional. ${ }^{192}$

Importa saber se a homologação é condição para que a sentença produza em território nacional toda sua eficácia como sentença, ou se apenas a eficácia executiva, ocasião na qual o processo de homologação se apresentará como de natureza constitutiva de eficácia executiva ou de natureza constitutiva geral condicionante de toda e qualquer eficácia da sentença.

Homologação de sentença estrangeira, cit., p. 90; PONTES DE MIRANDA, Francisco Cavalcanti. Comentários ao Código de Processo Civil. Rio de Janeiro: Forense, 1974. v. 6, p. 94-95; Amílcar de Castro não vê atividade jurisdicional no juízo de delibação. Ele entende não haver lugar para uma discussão de mérito, reputando-lhe a característica de jurisdição voluntária (Direito internacional privado, cit., p. 567-568).

191 MOREIRA, José Carlos Barbosa, Comentários ao Código de Processo Civil, cit., v. 5, p. 84; GRECO FILHO, Vicente, Homologação de sentença estrangeira, cit., p. 113 et seq.

192 ARAUJO, Nadia de, Direito internacional privado: teoria e prática brasileira, cit., p. 329; MOREIRA, José Carlos Barbosa, op. cit., v. 5, p. 84; FUX, Luís, Homologação de sentença estrangeira, cit., p. 643 et seq.; GRECO FILHO, Vicente, op. cit., p. 113 et seq.; HUCK, Hermes Marcelo, Sentença estrangeira e lex mercatoria: horizontes e fronteiras do comércio internacional, cit., p. 23-24; SERPA LOPES, Miguel Maria de, Comentários à Lei de Introdução ao Código Civil, cit., v. 3, p. 226-227; VALLADÃO, Haroldo, Direito internacional privado, cit., v. 3, p. 123; PONTES DE MIRANDA, Francisco Cavalcanti, Comentários ao Código de Processo Civil, cit., v. 6, p. 96. 
Como vem sendo afirmado no decorrer deste capítulo, o sistema de delibação adotado entre nós serve de molde para o processo de homologação, de modo que a sua natureza sofre inequívoca influência da concepção que se tenha da sentença estrangeira antes de homologada.

Como se demonstrou no item 2.2 deste capítulo, é perfeitamente distinguível a eficácia imperativa decorrente da autoridade da coisa julgada, da eficácia executiva ${ }^{193}$. A eficácia da coisa julgada atinge a conteúdo declaratório da certeza do direito e a execução, em caso de sentença condenatória, realiza-se por meio de um processo próprio posterior à declaração jurisdicional da certeza do direito.

Portanto, perfeitamente separáveis a declaração de certeza do direito sobre a qual recai a autoridade de coisa julgada e a eficácia executiva, sendo que nas sentenças em que não há condenação, a eficácia imperativa da coisa julgada permanece, não sendo necessária nenhuma outra providência jurisdicional para que sua eficácia se realize, o que a torna indissociável da própria sentença. Ainda, o efeito executivo decorre da própria declaração de certeza do direito. $^{194}$

Se o processo no exterior é verdadeiro processo, a sentença estrangeira é verdadeira sentença, ato jurisdicional dotado de eficácia de sentença. A eficácia imperativa, portanto, independe de qualquer conduta das partes para que os efeitos naturais e suscetíveis de serem produzidos por um ato jurídico se realizem. Tem-se assim que os efeitos decorrentes da sua imutabilidade lhe são inerentes ${ }^{195}$. E desse modo o processo de homologação a tem como pressuposto.

Ora, pode-se invocar uma sentença estrangeira para a eficácia decorrente da coisa julgada ou para executar um seu comando, situações distintas e independentes, sendo a primeira inerente à sentença estrangeira e a segunda dela decorrente. ${ }^{196}$

\footnotetext{
193 GRECO FILHO, Vicente, Homologação de sentença estrangeira, cit., p. 99-100; SERPA LOPES, Miguel Maria de, Comentários à Lei de Introdução ao Código Civil, cit., v. 3, p. 216-217 e 230-231.

${ }^{194}$ GRECO FILHO, Vicente, op. cit., p. 99; SERPA LOPES, Miguel Maria de, op. cit, p. 217-219.

195 GRECO FILHO, Vicente, op. cit., p. 99-100; SERPA LOPES, Miguel Maria de, op. cit., v. 3, p. 218-219.

${ }^{196}$ SERPA LOPES, Miguel Maria de, op. cit., p. 230-231. No mesmo sentido: GRECO FILHO, Vicente, op. cit., p. 100.
} 
Como dito, a sentença estrangeira só pode ser considerada como verdadeira sentença se lhe for atribuída de forma indissociável a eficácia declaratória imperativa, sem a qual o ato jurisdicional em questão não seria sentença. Portanto, no nosso sentir, de acordo com a sistemática do sistema de delibação, nem toda eficácia da sentença estrangeira depende de uma constituição integrativa, apenas a eficácia executiva e, por isso, reputamos o processo de homologação de sentença estrangeira como de natureza constitutiva de eficácia executiva. Assim também Vicente Greco Filho"197, ao afirmar que "a homologação de sentença estrangeira é ação constitutiva, exigível para a produção do efeito executivo, em sentido amplo, da sentença no Brasil”.

Reputamos esse entendimento coerente com o sistema de delibação adotado entre nós desde 1878, quando do Decreto n. 6.982. Muito embora Vicente Greco Filho ${ }^{198}$ afirme que "ao processo de homologação, desde que não lhe compete a atribuição de existência, compete a constituição de eficácia executiva para a ordem jurídica brasileira", no direito brasileiro vigente a situação não foi e ainda não é tão tranquila assim.

Abordaremos então as sentenças suscetíveis de homologação, oferecendo um panorama de como evoluiu a questão no Brasil e como hoje se encontra, coerente ou não com o sistema de delibação.

\subsection{Sentenças susceptíveis de homologação}

A limitação da jurisdição internacional como ato de soberania e a consequente adoção do sistema de delibação, por melhor se adaptar a essa concepção de que há outras jurisdições igualmente soberanas, implicam, ou mesmo pressupõem, reconhecer a sentença estrangeira como verdadeira sentença emanada de poder jurisdicional de soberania de igual dignidade. Sentenças, no entanto, que, por razões de ordem pública interna e de soberania, têm sua produção de efeitos sujeita à condição de seu reconhecimento pelo juízo de delibação exarado

\footnotetext{
${ }^{197}$ GRECO FILHO, Vicente, Homologação de sentença estrangeira, cit., p. 99, 106 et seq. No mesmo sentido entende Serpa Lopes, que chega a afirmar: "No sistema de controle limitado, a força inerente à sentença estrangeira não é condicionada senão ao preenchimento de determinados requisitos, reputados como essenciais para que o poder soberano do Estado consinta na sua executoriedade dentro do seu território." (Comentários à Lei de Introdução ao Código Civil, cit., v. 3, p. 200).

${ }^{198}$ GRECO FILHO, Vicente, op. cit., p. 102.
} 
no processo de homologação, fazendo-se necessário estabelecer quais efeitos a rigor dependem do juízo de delibação. ${ }^{199}$

Convém, por oportuno, frisar a nítida distinção entre a eficácia imperativa própria do ato sentencial e a eficácia executiva. Retomemos os ensinamentos de Celso Neves, para quem, esclarecida a certeza do direito, a sua realização prática se dá de forma voluntária, com a submissão ao comando imutável do decisium, ou é obtida mediante atos de execução forçada, deixando nítida a distinção entre a declaração de certeza do direito e a eficácia de execução da sentença. ${ }^{200}$

Após, ao se referir às sentenças constitutivas, tratando ainda da distinção acima, professa: “A sentença constitutiva efetua essa aproximação (da atividade jurisdicional de cognição e da atividade jurisdicional executória) eliminando a dualidade processual açãoexecução, porque os efeitos jurídicos pretendidos, no caso de acolhimento da ação, podem ser, desde logo, realizados."201

Oportuno colacionar os esclarecimentos de Serpa Lopes a respeito da distinção. Após não concordar com Machado Vilela, que abrangia na expressão execução todos os casos em que se pretendesse realizar os efeitos da sentença:

"Sob esse ponto de vista há uma diferença específica entre os dois efeitos: o
da coisa julgada e o efeito executório. Não se pode, assim, estabelecer uma
regra de generalidade, alcançando as sentenças estrangeiras de qualquer
espécie e seja qual for a forma de eficácia que se destinem a produzir.
Admitimos que, quando a eficácia de coisa julgada envolva,
inequivocamente, uma forma executória, o processo de delibação se torna
necessário, ainda que sob uma forma incidente."."202

Muito embora a coisa julgada não seja propriamente um efeito da sentença, da situação de imutabilidade decorrem efeitos vários, dentre eles o executório e outros que independem de qualquer outro ato para se exaurirem. Não há, portanto, equiparação a ser feita entre os efeitos que decorrem da autoridade de coisa julgada e a força executiva da sentença.

\footnotetext{
${ }^{199}$ GRECO FILHO, Vicente, Homologação de sentença estrangeira, cit., p. 93.

${ }^{200}$ NEVES, Celso, Coisa julgada civil, cit., p. 449 et seq.

${ }^{201}$ NEVES, Celso, op. cit., p. 449 et seq. No mesmo sentido, inclusive citando Celso Neves: GRECO FILHO, Vicente, op. cit., p. 98 et seq.

${ }^{202}$ SERPA LOPES, Miguel Maria de, Comentários à Lei de Introdução ao Código Civil, cit., v. 3, p. 219.
} 
Quer nos parecer claro que a sentença constitutiva não depende de nenhum ato de execução forçada. A própria sentença constitutiva, com sua força jurídica (eficácia imperativa), é suficiente para produzir o efeito desejado e contido no comando de certeza do direito.

Portanto, não há como não reconhecer que as sentenças declaratórias e constitutivas, uma vez transitadas em julgado, produzem, por si só, independentemente da colaboração do vencido, e bem assim de qualquer ato material incidente sobre seu patrimônio, os mesmos efeitos que teria a realização, com êxito, dos atos executórios típicos nas sentenças condenatórias. Nessas duas sentenças, nenhuma atividade executiva propriamente dita se realiza, o que permite concluir que sua eficácia imperativa lhe basta, sendo-lhes, também, indissociável.

Como esclarecido quando tratamos da natureza jurídica da sentença estrangeira, verificamos que a eficácia imperativa the é inerente, indissociável do próprio conceito de sentença, de modo que sua eficácia, seja para constituir ou desconstituir uma relação jurídica, ou apenas declarar um direito, exaure naturalmente. O mesmo não ocorre com a eficácia executiva que, como visto, depende para sua realização de outros atos jurisdicionais.

A eficácia do conteúdo declarativo de certeza jurídica que está compreendida em todas as categorias de sentença não é dada pelo processo de homologação. Preexiste a ele. E assim, como a própria sentença estrangeira, vez que é parte integrante desta, lhe serve de pressuposto. A homologação não outorga força de coisa julgada. Outorga efeitos executivos, tornando a sentença estrangeira apta a sustentar um processo executório em território nacional.

Em outras palavras, a situação de coisa julgada torna a sentença apta a produzir todos os seus efeitos, exceto os que dependem de atos executórios, posto que não se exaurem por si mesmos, ao contrário das sentenças declaratórias e constitutivas. 
Vicente Greco Filho ${ }^{203}$, o melhor expositor do tema, no nosso sentir, afirma com base em Chiovenda que admitir que a sentença estrangeira não tenha eficácia alguma antes de homologada é predominar ideia exacerbada de soberania.

E como já dissemos, o sistema de delibação, que vige no Brasil desde 1878, é calcado nessas premissas, quais sejam a de que a limitação da jurisdição nacional implica em reconhecer na sentença estrangeira verdadeira sentença, devendo, assim, ser respeitada.

Por isso, entendemos o parágrafo único do artigo 15 da Lei de Introdução às Normas do Direito Brasileiro em perfeita coerência com o sistema de delibação, tal como exposto até o momento. Muito embora, a par dessa distinção que nos parece nítida e que se revela nos exatos termos do parágrafo único do artigo 15, outros diplomas legislativos sucederam à Lei de Introdução ao Código Civil de 1942, o que acarretou turbulência quanto à coerente interpretação do referido dispositivo legal ${ }^{204}$. É o que se verá.

\subsubsection{Sentenças declaratórias de estado}

Historicamente, o ordenamento jurídico brasileiro deu tratamento distinto à sentença estrangeira quanto a duas eficácias, qual seja a executória e a que decorre naturalmente de sua eficácia jurídica de sentença (declaratória e constitutiva).

Em todos os regramentos legais brasileiros que versaram sobre a matéria, encontra-se expressa a exigência de prévia homologação para que a sentença estrangeira possa ser, em território brasileiro, executada. E quanto a esse ponto, não houve controvérsia. ${ }^{205}$

Controvérsia houve e ainda há quanto à necessidade de homologação para as demais sentenças estrangeiras, as declaratórias e as constitutivas.

\footnotetext{
${ }^{203}$ GRECO FILHO, Vicente, Homologação de sentença estrangeira, cit., p. 95.

${ }^{204}$ GRECO FILHO, Vicente, op. cit., p. 94 et seq.; MOREIRA, José Carlos Barbosa, Comentários ao Código de Processo Civil, cit., v. 5, p. 77; SERPA LOPES, Miguel Maria de, Comentários à Lei de Introdução ao Código Civil, cit., v. 3, p. 219 e ss.; VALLADÃO, Haroldo, Direito internacional privado, cit., v. 3, p. 190-191; TIBURCIO, Carmen. As inovações da EC 45/2004 em matéria de homologação de sentenças estrangeiras. In: Temas de direito internacional. Rio de Janeiro: Renovar, 2006. p. 191-206; DOLINGER, Jacob. Direito civil internacional: a família no direito internacional privado: casamento e divórcio no direito internacional privado. Rio de Janeiro: Renovar, 1997. v. 1, t. 1, p. 229.

${ }^{205}$ MOREIRA, José Carlos Barbosa, op. cit., p. 74-75; GRECO FILHO, Vicente, op. cit., p. 94; SERPA LOPES, Miguel Maria de, op. cit., p. 221-228; TIBURCIO, Carmen, op. cit., p. 207.
} 
Como já relatado, o precursor em instituir o sistema de delibação foi o Código de Processo italiano de 1865, que exigia a homologação apenas para a execução, silenciando a respeito da necessidade de homologação das sentenças declaratórias de direitos ou de estado, cuja leitura feita pela doutrina era a de que seria dispensável o procedimento homologatório dessas últimas ${ }^{206}$. No entanto, o Código de Processo Civil de 1942, contaminado por uma ideia exacerbada de soberania, passou a tratar de forma ampla o juízo de delibação, o que acarretou a interpretação de que seria necessária a homologação de quaisquer sentenças para produção de efeitos em território italiano. ${ }^{207}$

Conforme relatado no item 2.1 deste capítulo, grande influência sofreu o direito brasileiro. O Decreto n. 6.982 de 1878 exigia-se o "cumpra-se" para que, em território nacional, fossem exequíveis as sentenças estrangeiras. E no artigo 12 fazia a ressalva de que os efeitos de coisa julgada se produziriam independentemente do "cumpra-se", desde que presentes os requisitos legais do artigo $1^{\circ}$ e que não se ofendesse o disposto no artigo $2^{\circ}$.

Sucedeu-lhe a Lei n. 221 de 1894, instituindo um juízo formal de homologação de competência do Supremo Tribunal Federal, mantendo a necessidade de homologação para que as sentenças estrangeiras fossem exequíveis.

Serpa Lopes afirma que com o advento da Consolidação das Leis da Justiça Federal, aprovada pelo Decreto n. 3.084 de 1898, iniciava-se o dissídio doutrinário. Afirma que esse Decreto havia reproduzido os artigos 10, 11 e 13 do Decreto n. 6.982, que exigiam a homologação para execução das sentenças estrangeiras em território brasileiro, no entanto sem reproduzir o artigo 12, que dispensava a necessidade de homologação para os efeitos da coisa julgada. A indagação que se fazia à época, segundo Serpa Lopes, era a seguinte: “A supressão significaria incompatibilidade ou que o princípio era tão evidente que mister não era corporificá-lo?"208

\footnotetext{
${ }^{206}$ MOREIRA, José Carlos Barbosa, Comentários ao Código de Processo Civil, cit., v. 5, p. 76-77; GRECO FILHO, Vicente, Homologação de sentença estrangeira, cit., p. 94 et seq.; VALLADÃO, Haroldo, Direito internacional privado, cit., v. 3, p. 193.

${ }^{207}$ MOREIRA, José Carlos Barbosa, op. cit., p. 76-77; GRECO FILHO, Vicente, op. cit., p. 94 et seq.; VALLADÃO, Haroldo, op. cit., p. 193.

${ }^{208}$ SERPA LOPES, Miguel Maria de, Comentários à Lei de Introdução ao Código Civil, cit., v. 3, p. 220-221.
} 
Afirma que Clóvis Beviláqua e Samuel Martins, em se tratando de coisa julgada, pugnavam por sua eficácia de plano, enquanto Machado Vilela entendia que as sentenças estrangeiras não poderiam ter eficácia de coisa julgada no Brasil sem que tivessem a chancela da homologação pelo Supremo Tribunal Federal. ${ }^{209}$

Haroldo Valladão também defende que as sentenças estrangeiras não possuíam eficácia alguma no Brasil, sem que tivessem sido homologadas e refere que a jurisprudência do Supremo Tribunal Federal havia oscilado entre 1915 a 1920, porém se orientava no sentido da necessidade de homologar todo e qualquer julgado estrangeiro. ${ }^{210}$

A Lei de Introdução ao Código Civil de 1916 não regulava especificamente o tema e, do mesmo modo, no Código de Processo Civil de 1939 perpetuava-se a omissão ao tratamento a ser dado às sentenças declaratórias. Mantinha-se, no entanto, a terminologia de homologação para execução. ${ }^{211}$

A Lei de Introdução ao Código Civil de 1942 revigorou, em seu artigo 15, parágrafo único, a dispensa de homologação das sentenças declaratórias de estado das pessoas. Havia, novamente, norma específica para o tema. ${ }^{212}$

Haroldo Valladão deixava claro que entendia estar em vigor esse diploma legal, salvo o parágrafo único do artigo 15. O dispositivo, a seu ver, rompia abruptamente com a jurisprudência e voltava à orientação abandonada. Seu argumento residia no fato do que a Constituição Federal atribuía ao Supremo a competência para homologar todas as sentenças estrangeiras, sem exceção. Registrava "além do absurdo, e inconveniência da inovação, a sua inconstitucionalidade", pelo fato de que a Constituição de 1937 (em seu art. 101, I, “f”)

\footnotetext{
${ }^{209}$ SERPA LOPES, Miguel Maria de, Comentários à Lei de Introdução ao Código Civil, cit., v. 3, p. 221.

${ }^{210}$ TIBURCIO, Carmen, As inovações da EC 45/2004 em matéria de homologação de sentenças estrangeiras, in Temas de direito internacional, cit., p. 201; VALLADÃO, Haroldo, Direito internacional privado, cit., v. 3, p. 190.

${ }^{211}$ SERPA LOPES, Miguel Maria de, op. cit., p. 222; VALLADÃO, Haroldo, op. cit., p. 190; MOREIRA, José Carlos Barbosa, Comentários ao Código de Processo Civil, cit., v. 5, p. 76.

212 “Art. 15 - Será executada no Brasil a sentença proferida no estrangeiro, que reúna os seguintes requisitos: a) haver sido proferida por juiz competente; b) terem sido as partes citadas ou haver-se legalmente verificado a revelia; c) ter passado em julgado e estar revestida das formalidades necessárias para a execução no lugar em que foi proferida; d) estar traduzida por intérprete autorizado; e) ter sido homologada pelo Supremo Tribunal Federal. Parágrafo único - Não dependem de homologação as sentenças meramente declaratórias do estado das pessoas."
} 
sujeitava todas as sentenças estrangeiras à homologação, não sendo possível, a seu ver, que lei ordinária viesse a excluir competência constitucional do Supremo Tribunal Federal. ${ }^{213}$

Esclarece que muito embora não tenha o Supremo Tribunal Federal declarado a inconstitucionalidade da norma, passou a não aplicá-la, exigindo a homologação, praticamente, de todas as "sentenças de estado, divórcio, desquite, anulação de casamento, investigação de paternidade, adoção, etc.". ${ }^{214}$

O Regimento Interno do Supremo Tribunal Federal de 1970 repetia o parágrafo único do artigo 15. Haroldo Valladão esclarece, contudo, que o Supremo não o aplicava, seguindo a orientação da imprescindibilidade da homologação de todas as sentenças estrangeiras, sempre sob o argumento de que lei infraconstitucional não poderia retirar a competência constitucional do Supremo Tribunal Federal. ${ }^{215}$

Serpa Lopes chegou a afirmar que foi a autorizada opinião de Haroldo Valladão que determinou na jurisprudência a não aplicação do referido dispositivo. No entanto, parece não ter aderido a esse entendimento. A seu ver, a determinação da competência do Supremo Tribunal se referia apenas à competência para homologar as sentenças que a legislação infraconstitucional assim determinasse. Não havia nenhum dispositivo que determinasse de forma imperativa que toda sentença estrangeira devesse ser homologada, fosse qual fosse a sua natureza para que, só então, pudesse surtir efeitos em território nacional. Entendia que a análise relativa a ofensas à soberania, ordem pública e bons costumes previstas no artigo 17 da Lei de Introdução ao Código Civil far-se-ia pelo juiz perante o qual a sentença estrangeira houvesse de atuar ${ }^{216}$. Assim também Oscar Tenório. ${ }^{217}$

A opinião de Serpa Lopes merece registro:

\footnotetext{
213 VALLADÃO, Haroldo, Direito internacional privado, cit., v. 3, p. 187, 190-191. Na realidade, a Constituição de 1937 não falava em homologação das sentenças estrangeiras. Em 1946, por emenda de Aldroaldo da Costa, o texto veio a ser alterado com o objetivo de estabelecer a regra de que toda sentença proferida por tribunal estrangeiro dependeria de homologação (TIBURCIO, Carmen. As inovações da EC 45/2004 em matéria de homologação de sentenças estrangeiras, in Temas de direito internacional, cit., p. 202203).

${ }^{214}$ VALLADÃO, Haroldo, op. cit., p. 187 e 190-191.

215 Ibidem, p. 192.

${ }^{216}$ SERPA LOPES, Miguel Maria de, Comentários à Lei de Introdução ao Código Civil, cit., v. 3, p. 223 e 228.

217 TENÓRIO, Oscar Accioly, Lei de Introdução ao Código Civil Brasileiro: Decreto-Lei n. 4.657, de 4 de setembro de 1942, cit., n. 596, p. 229.
} 
"A corrente intransigente, inspirada em motivos de ordem constitucional ou em outros, alimenta-se de um exagerado sentimento político, apega-se a um demasiado estreito conceito de soberania, o qual, se não está morto, como pretendeu DUGUIT, pelo menos não pode entravar o progresso das instituições, em homenagem a uma majestade inútil e sem resultados práticos.

O princípio verdadeiro é o jurídico, princípio que anima, como vimos, todo o sistema anglo-saxônico. Ao Estado cabe apenas velar pela salvaguarda dos preceitos fundamentais da sua ordem jurídica. Estes exigem, de fato, em se tratando de executar uma ordem judicial, uma forma especial, como é a delibação, mas de modo nenhum generalizada a todas as hipóteses, a todos os efeitos das sentenças estrangeiras. Veremos, no curso do presente comentário, como, em determinados casos, a delibação apresenta-se um aparelho fecundo em dificuldades dispensáveis. Tenhamos, como ponto de partida, esse conceito bem justo de BARTIN: na res judicata, pura e simplesmente, não se trata de executar, mas de utilizar-se de todos os efeitos da sentença." 218

$\mathrm{O}$ argumento utilizado para sustentar a inconstitucionalidade da norma específica do artigo 15 da Lei de Introdução ao Código Civil, cuja consequência era a de que todas as sentenças deveriam ser homologadas pela mais alta corte judiciária nacional, sustentava-se na redação das Constituições estabelecendo a homologação das sentenças estrangeiras. Argumentavam que dessa maneira redigido não se poderia estabelecer uma regra excepcionando a homologação. No entanto, sem embargo da entrada em vigor do Código de Processo Civil e seu artigo 483, o argumento viria a ser superado pelo simples fato de a Emenda Constitucional n. 45/2004 ter alterado a redação da Constituição passando, a constar a homologação de sentenças estrangeiras e não mais homologação das sentenças estrangeiras.

Em vigor o Código de Processo Civil de 1973, o seu artigo $483^{219}$ determinava que as sentenças estrangeiras não teriam eficácia no Brasil caso não houvessem sido homologadas pelo Supremo Tribunal Federal. O alcance do artigo 483 do Código de Processo Civil foi e ainda é alvo de polêmica, por conta da determinação da norma específica contida no parágrafo único do artigo 15 da Lei de Introdução ao Código Civil, que não exigia e não exige homologação das sentenças meramente declaratórias de estado para que elas surtam seus inerentes efeitos.

\footnotetext{
218 SERPA LOPES, Miguel Maria de, Comentários à Lei de Introdução ao Código Civil, cit., v. 3, p. 228.

219 “Art. 483. A sentença proferida por tribunal estrangeiro não terá eficácia no Brasil senão depois de homologada pelo Supremo Tribunal Federal."
} 
Sustentavam alguns, a exemplo de Haroldo Valladão ${ }^{220}$, que o artigo do Código de Processo Civil liquidava a questão, por ter revogado a parte final do artigo 210 do Regimento Interno do Supremo Tribunal Federal ("salvo as meramente declaratórias do estado das pessoas"). $^{221}$

Barbosa Moreira esclarece que a expressão eficácia liquida qualquer dúvida e que não há espaço em nosso ordenamento para delibação incidental, seja qual for a matéria que se cogite, pois, segundo ele, inexiste a figura do reconhecimento distinta da homologação ${ }^{222}$. Assim também Nadia de Araujo, para quem, em decorrência da modificação do Código de Processo Civil, a regra se aplica a todas as decisões estrangeiras, em face de seu caráter imperativo. Afirma, ao comentar a Resolução n. 9 do Superior Tribunal de Justiça, que o artigo 483 do Código de Processo Civil revogou o dispositivo. ${ }^{223}$

A prevalecer esse entendimento, forçoso concluir que a sentença estrangeira antes de homologada não seria uma verdadeira sentença. Antes de mais nada, a postura diante do artigo 15, parágrafo único, reflete a concepção que se tem da sentença estrangeira, bem como a postura que se tem em relação à limitação da jurisdição estatal, seus pressupostos e consequências.

Por outro lado, a nosso ver, o parágrafo único do artigo 15 estabelece regra específica e é categórico ao afirmar que a sentença que, para se realizar por completo, dependa de atos executórios, deve ser homologada no Supremo Tribunal Federal.

Jacob Dolinger ${ }^{224}$ entende que o Superior Tribunal de Justiça, e anteriormente o Supremo Tribunal Federal, detém a competência interna originária para homologar as sentenças estrangeiras que, por determinação legal, devam ser homologadas. Deixa claro que

${ }^{220}$ VALLADÃO, Haroldo, Direito internacional privado, cit., v. 3, p. 193.

221 "Art. 210 - As sentenças estrangeiras, cíveis ou criminais, não serão exequíveis no Brasil, sem prévia homologação do Supremo Tribunal federal, salvo as meramente declaratórias de estado."

${ }^{222}$ MOREIRA, José Carlos Barbosa. Notas sobre o reconhecimento e execução de sentenças estrangeiras. In: TIBURCIO, Carmen; BARROSO, Luis Roberto (Orgs.). Direito internacional contemporâneo: estudos em homenagem ao professor Jacob Dolinger. Rio de Janeiro: Renovar, 2006. p. 549-554; e Comentários ao Código de Processo Civil, cit., v. 5, p. 74-75 e 78-79. No mesmo sentido: VALLADÃO, Haroldo, op. cit., p. 193.

223 ARAUJO, Nadia de (Coord.), Cooperação jurídica internacional no Superior Tribunal de Justiça: comentários à Resolução n. 9/2005, cit., p. 41.

${ }^{224}$ DOLINGER, Jacob, Direito civil internacional: a família no direito internacional privado: casamento e divórcio no direito internacional privado, cit., v. 1, t. 1, p. 229. 
entende não ser matéria constitucional ou matéria a ser tratada na Constituição Federal quais sentenças devam ser submetidas ao processo formal de homologação para que só então produzam seus inerentes efeitos. De fato não o são. Entende, portanto, em plena vigência o dispositivo da Lei de Introdução ao Código Civil.

Carmen Tiburcio $^{225}$ ressalta a importância da alteração da redação do dispositivo que tratava da homologação das sentenças estrangeiras, passando agora para homologação de sentenças estrangeiras. Afirma que a nova redação dada ao artigo 105, I, torna o Superior Tribunal de Justiça competente para a homologação de sentenças estrangeiras, e não mais das sentenças estrangeiras, como previsto nas Constituições de 1946 até a de 1988, em sua redação original, e, portanto, a tese da inconstitucionalidade do parágrafo único do artigo 15 teria apenas valor histórico, pois esse era o seu argumento.

Mais adiante, e com extrema clareza, entende ser possível compatibilizar a aplicação do artigo 483 do Código de Processo Civil com o parágrafo único do artigo 15 da Lei de Introdução ao Código Civil, pois, muito embora o primeiro seja posterior, ele trata da homologação para a execução, enquanto o segundo trata apenas do reconhecimento, que é ato declaratório de existência. E conclui: “Assim, o art. 483 pode ser interpretado como se referindo aos efeitos executivos da decisão estrangeira, e não todos os seus efeitos, como pretendem os seguidores da segunda corrente."226

De fato, essa é a interpretação que reputamos a mais correta e que se fundamenta no critério da especialidade das normas. Dessa forma, entendemos necessária a homologação como pressuposto para a execução de sentenças estrangeiras, e não para o seu reconhecimento como sentença.

Há que se ressaltar, contudo, que a jurisprudência do Supremo Tribunal Federal sempre se orientou para a necessidade de homologar toda e qualquer sentença estrangeira como condição para que elas liberem sua eficácia, seja ela qual for ${ }^{227}$. No entanto, atualmente, a matéria se encontra sob o crivo do Superior Tribunal de Justiça. E esse Tribunal Superior,

\footnotetext{
225 TIBURCIO, Carmen. As inovações da EC 45/2004 em matéria de homologação de sentenças estrangeiras, in Temas de direito internacional, cit., p. 191 et seq. ${ }^{226}$ Ibidem, p. 206.

227 ARAUJO, Nadia de (Coord.), Cooperação jurídica internacional no Superior Tribunal de Justiça: comentários à Resolução n. 9/2005, cit., p. 43.
} 
embora não em decorrência da sua nova competência acrescida pela Emenda Constitucional n. 45, manifestou-se a respeito da plena vigência do parágrafo único do artigo 15 da Lei de Introdução ao Código Civil.

No Recurso Especial n. 20.609, de 1993, em que lhe foi submetida a análise a vigência do dispositivo legal, entendeu pela desnecessidade de homologação de sentenças meramente declaratórias do estado das pessoas. ${ }^{228}$

Do voto do relator Ministro Dias Trindade, notamos uma verdadeira delibação incidente. Vejamos:

\begin{abstract}
"Exige o art. 15 da Lei de Introdução que a sentença estrangeira, para ser cumprida em nosso país, há de atender aos requisitos de competência do juiz que a proferir, citação das partes, tradução por intérprete autorizado e homologação pelo Supremo Tribunal Federal, dispensado este último quando se cuidar de sentença meramente declaratória do estado das pessoas. Ora, no caso, tida como dispensável a homologação, seria de examinarmos os demais requisitos, para que se pudesse emprestar executoriedade à sentença estrangeira de que se cuida e é evidente que falta o requisito da letra b), desde que quando não se noticia que os interessados tenham sido citados para a ação de que resultou a sentença, que, desse modo, não poderia ser executada em nosso país." (grifamos)
\end{abstract}

Há ainda um julgado de 2005, o Recurso Especial n. 535.646. Dele também se nota o entendimento da não necessidade de homologação das sentenças estrangeiras relativas ao estado das pessoas. Havia uma sentença de divórcio proferida na Espanha e se buscava seu cumprimento em território nacional independentemente de homologação. ${ }^{229}$

\footnotetext{
228 “Civil. Processual Civil. Embargos infringentes. Limites. Sentença estrangeira. Executoriedade no Brasil. Requisitos. 1. Os embargos infringentes devolvem ao órgão julgador a matéria sobre que versou a divergência como expressa no voto vencido (art. 530 do CPC). 2. Sentença estrangeira, meramente declaratória do estado das pessoas, dispensa a homologação, mas só é executável no Brasil se atender os demais requisitos do artigo 15 da Lei de Introdução ao Código Civil.” (ARAUJO, Nadia de (Coord.), Cooperação jurídica internacional no Superior Tribunal de Justiça: comentários à Resolução n. 9/2005, cit., p. 43).

229 "Partilha de bens. Separação decretada na Espanha. Competência da Justiça brasileira para decidir a partilha de bens imóveis localizados no país. Ausência de necessidade de homologação de sentença estrangeira sobre o estado das pessoas. Art. 15, parágrafo único, da Lei de Introdução ao Código Civil. 1. Havendo nos autos, confirmado pelo acórdão, partilha de bens em decorrência de separação, impõe-se o processo de homologação no Brasil, aplicando-se o art. 89, II, do Código de Processo Civil apenas em casos de partilha por sucessão causa mortis. 2. Não há necessidade de homologação de sentenças meramente declaratórias do estado das pessoas (art. 15, parágrafo único, da Lei de Introdução ao Código Civil). 3. Recurso especial conhecido e provido." (ARAUJO, Nadia de (Coord.), op. cit., p. 44).
} 
O relator Ministro Carlos Alberto Menezes de Direito assim se manifestou:

\begin{abstract}
"No caso, concretamente, o que se está fazendo é reconhecer, para o que não há necessidade de homologação, que a autora estava de fato separada do de cujus e que pretende ver reconhecido seu direito à partilha dos bens adquiridos durante a constância do casamento, localizados no Brasil.

$\mathrm{Na}$ verdade, o que se pretende extrair dos autos é que foi decretada a separação na Espanha e que essa separação dispensa homologação no Brasil.” (grifamos).
\end{abstract}

A nosso ver, como explanado nos julgados acima, a operação de reconhecimento de existência da sentença estrangeira e dos efeitos que lhe são inerentes (eficácia imperativa), além de pressuposto do sistema de delibação, é declaratória, e o reconhecimento da sentença como tal não depende de homologação. Assim, nem toda eficácia da sentença estrangeira depende de uma constituição integrativa, apenas a executiva.

Por todo exposto, independentemente da linha adotada quanto à vigência ou não do parágrafo único do artigo 15, fato é que ele nos parece coerente com os pressupostos lógicos para a existência do sistema de delibação, que por sua vez se assenta na premissa de que a sentença estrangeira é verdadeira sentença produtora de efeitos que independem de qualquer outro ato.

\title{
2.5.2 Sentenças extraterritoriais
}

O Brasil, em observância ao espírito integracionista insculpido na Constituição Federal (art. $4^{\circ}$, inc. IX e parágrafo único) ${ }^{230}$, firmou instrumentos de cooperação judiciária internacional, dentre os quais, e o que nos interessa neste ponto, o Protocolo de Las Leñas. Esse instrumento internacional dispõe, além de outros assuntos, sobre a extraterritorialidade das sentenças e laudos arbitrais, cujo precípuo objetivo foi o de conferir eficácia extraterritorial às sentenças e laudos emanados de países do Mercosul em matéria civil, comercial, trabalhista e administrativa. ${ }^{231}$

\footnotetext{
230 “Art. 4" - A República Federativa do Brasil rege-se nas suas relações internacionais pelos seguintes princípios: [...] IX - cooperação entre os povos e progresso da humanidade. [...] Parágrafo único - A República Federativa do Brasil buscará a integração econômica, política, social e cultural dos povos da América Latina, visando à formação de uma comunidade latino-americana de nações."

${ }^{231}$ MAGALHÃES, José Carlos de. O Supremo Tribunal Federal e o direito internacional: uma análise crítica. Porto Alegre: Livraria do Advogado, 2000. p. 105.
} 
Desse modo, a eficácia das sentenças estrangeiras e dos laudos arbitrais proferidos em países que integram o Mercosul será regulada pelo Protocolo de Cooperação e Assistência Jurisdicional em Matéria Civil, Comercial, Trabalhista e Administrativa. O referido Protocolo, denominado Protocolo de Las Leñas, em referência à cidade argentina onde foi celebrado, foi firmado pelo Brasil, Argentina, Paraguai e Uruguai, Estados partes do Mercosul, em 27 de junho de 1992, aprovado pelo Decreto Legislativo n. 55, de 19 de abril de 1995, e promulgado pelo Decreto n. 2.067, de 12 de novembro de 1996.

Trataremos agora dos dois artigos que nos interessam. O artigo 19 do Protocolo dispõe:

"Art. 19 - O pedido de reconhecimento e execução de sentenças e de laudos arbitrais por parte das autoridades jurisdicionais será transmitido por via de cartas rogatórias e por intermédio da Autoridade Central."

O artigo permite que se promova a "homologação" de sentenças originárias dos países membros através de um procedimento simplificado, mediante carta rogatória, o que reflete o espírito que rege a cooperação em matéria judiciária entre os países signatários.

Esse artigo, como se vê, simplifica o procedimento de homologação das sentenças provenientes dos países do Mercosul que não possuírem os requisitos do artigo 20. Ao invés de observar o procedimento padrão para o reconhecimento de sentenças estrangeiras, bastaria a carta rogatória, que é ato de cooperação judicial a ser cumprido, tal como a precatória no âmbito interno. A carta rogatória expedida pelo juiz do processo estrangeiro, nesses casos, servirá para requerer a homologação da sentença judicial estrangeira.

Note-se, no entanto, que esse artigo não se aplica às sentenças que contenham os requisitos do artigo 20 do Protocolo. Para essas, a situação é bem distinta e assim deve ser interpretada:

"Art. 20 - As sentenças e os laudos arbitrais a que se refere o artigo anterior terão eficácia extraterritorial nos Estados Partes, quando reunirem as seguintes condições:

a) que venham revestidas das formalidades externas necessárias para que sejam considerados autênticos no Estado de origem;

b) que estejam, assim como os documentos anexos necessários, devidamente traduzidos para o idioma oficial do Estado em que se solicitou o seu reconhecimento e execução; 
c) que emanem de um órgão jurisdicional ou arbitral competente, segundo as normas do Estado requerido sobre jurisdição internacional;

d) que a parte contra a qual se pretende executar a decisão tenha sido devidamente citada e tenha garantido o exercício de seu direito de defesa;

e) que a decisão tenha força de coisa julgada e/ou executória no Estado em que foi ditada;

f) que claramente não contrariem os princípios de ordem pública do Estado em que se solicita seu reconhecimento e/ou execução.

Os requisitos das alíneas (a), (c), (d), (e) e (f) devem estar contidos na cópia autêntica da sentença ou do laudo arbitral."

Observados esses requisitos, a sentença proveniente de um dos países signatários produzirá no outro seus efeitos diretamente, sem necessidade da homologação a que estão submetidas as demais sentenças provenientes de países de fora da área comum do Sul.

Note-se, por oportuno, que a alínea "f" contém duas situações distintas e uma alternativa. Uma, a do reconhecimento e, outra, da execução. Ou o próprio juiz que proferiu a sentença é que requer, via carta rogatória, seu reconhecimento através do procedimento simplificado de homologação, ou, uma vez atendidos todos os requisitos, a parte interessada requer a execução diretamente ao juiz de primeiro grau, em decorrência da sua eficácia extraterritorial. No entanto, em ambos os casos, conforme a alínea em comento, devem ser respeitados os princípios de ordem pública do Estado em que se invocará a decisão.

Do mesmo modo, os artigos 22 e $24^{232}$ contemplam a distinção das situações, o que não deixa dúvida quanto à distinção e às duas possibilidades, qual seja a do reconhecimento por meio do procedimento simplificado instituído pelo artigo 19 e a execução direta, uma vez atendidos os requisitos do artigo 20 .

\footnotetext{
232 “Art. 22 - Quando se tratar de uma sentença ou de um laudo arbitral entre as mesmas partes, fundamentado nos mesmo fatos, e que tenha o mesmo objeto de outro processo judicial ou arbitral no Estado requerido, seu reconhecimento e sua executoriedade dependerão de que a decisão não seja incompatível com outro pronunciamento anterior ou simultâneo proferido no Estado requerido. Do mesmo modo não se reconhecerá nem se procederá à execução, quando se houver iniciado um procedimento entre as mesmas partes, fundamentado nos mesmos fatos e sobre o mesmo objeto, perante qualquer autoridade jurisdicional da Parte requerida, anteriormente à apresentação da demanda perante a autoridade jurisdicional que teria pronunciado a decisão da qual haja solicitação de reconhecimento. [...] Artigo 24 - Os procedimentos, inclusive a competência dos respectivos órgãos jurisdicionais, para fins de reconhecimento e execução de sentenças ou laudos arbitrais, serão regidos pela lei do Estado requerido."
} 
Nem todas as sentenças provenientes dos Estados partes, desse modo, gozam de extraterritorialidade. As que não atendem os requisitos acima, devem ser homologadas, conforme estabelecido no artigo $19 .^{233}$

No entanto, uma vez atendidos os requisitos estabelecidos no artigo 20, o juiz de primeiro grau, a quem deve, pela parte interessada, ser dirigido diretamente o pedido de execução das sentenças extraterritoriais a que se refere esse artigo, deverá, independentemente de homologação do Superior Tribunal de Justiça, ordenar o processamento da execução, como se nacional fosse a sentença. Isso ocorre porque, como já observado quando tratamos da jurisdição internacional do juiz brasileiro, o Protocolo de Las Leñas, bem como o Protocolo de Buenos Aires em matéria contratual, conferiram jurisdição internacional regional aos juízes do Mercosul sobre seus objetos, cujas sentenças, consequentemente, produzirão sua eficácia executiva (autorizar a instauração de procedimento executório) independentemente de qualquer outra providência jurisdicional.

José Carlos de Magalhães, após esclarecer que o Supremo Tribunal Federal, ao invés de bem acolher os instrumentos de cooperação internacional firmados pelo Brasil, lhes cria obstáculos, enaltece o objetivo almejado pelo Protocolo de Las Leñas, da seguinte forma:

"O efeito extraterritorial da sentença provinda de outro país constitui importante e decisivo passo para o processo de integração regional, tendendo a aproximar cada vez mais os povos e permitir o mútuo conhecimento dos seus sistemas jurídicos, ao mesmo tempo em que conduz à harmonização progressiva das legislações e do tratamento jurisprudencial sobre aqueles temas." 234

Essa eficácia extraterritorial dada pelo artigo 20 equivale a uma atribuição de jurisdição internacional-regional aos poderes judiciários dos Estados partes pelo Protocolo, evidentemente nas matérias civil, comercial, trabalhista e administrativa, de modo que as sentenças terão, uma vez proferidas, uma eficácia internacional, ainda que regional, pois a sentença, assim como o laudo arbitral, terá eficácia plena no território dos países membros do Mercosul. Possuirão, dessa forma, efeito internacional. ${ }^{235}$

\footnotetext{
${ }^{233}$ José Carlos de Magalhães entende que caso assim não se interpretem as disposições comentadas, não haveria razão para existir o referido protocolo, opinião que, a nosso sentir, não comporta reparos ( $O$ Supremo Tribunal Federal e o direito internacional: uma análise crítica, cit., p. 120).

${ }^{234}$ MAGALHÃES, José Carlos de, O Supremo Tribunal Federal e o direito internacional: uma análise crítica, cit., p. 115.

${ }^{235}$ Ibidem, p. 117-118.
} 
Não se trata, como visto, de sentença estrangeira despida de eficácia executiva, que para produzir efeitos em um dos Estados membros necessitaria de homologação judicial, para que só então, acolhida por ato oficial, produzisse seus efeitos.

Muito embora não proceda de um tribunal ou corte internacional de que o Brasil faça parte, em razão de seus efeitos internacionais, poderia ser incluída na categoria de sentenças internacionais, as quais, como se verá em seguida, também, dispensam qualquer ato jurisdicional do país onde será invocada, para a plena produção de todos os seus efeitos. ${ }^{236}$

\subsubsection{Sentenças internacionais}

Como brevemente tratado acima, as sentenças internacionais não provêm de autoridades judiciárias nacionais, pelo que não se enquadram na definição de sentença estrangeira bem esclarecida por Serpa Lopes ${ }^{237}$. São sentenças emitidas por cortes ou tribunais internacionais portadores de jurisdição internacional conferida pelos Estados, no pleno exercício de sua soberania, por meio de convenções ou tratados internacionais, sendo essa jurisdição internacional fruto da legislação internacional. Haverá, consequentemente, uma submissão do Estado a essa jurisdição internacional. ${ }^{238}$

A jurisdição internacional aceita pelo Estado, seja por ter convencionado dessa forma em tratado, seja por ter, em acordo especial, concordado em submeter a solução de determinada controvérsia a um órgão judiciário internacional, ou mesmo ter aceito submeter um seu litígio a um tribunal arbitral internacional conferindo, assim, jurisdição para a autoridade nomeada resolver o litígio, é obrigatória. Uma vez aceita mediante declaração formal, o país, em relação à sentença daí decorrente, ver-se-á obrigado a dar-lhe cumprimento. Caso assim não o faça, estará sujeito às sanções que a comunidade

\footnotetext{
${ }^{236}$ MAGALHÃES, José Carlos de, O Supremo Tribunal Federal e o direito internacional: uma análise crítica, cit., p. 115-116.

237 "Desde que o órgão judicante não recebe a sua jurisdição da mesma soberania, desde que a sentença é proferida por um juiz ou tribunal ligado a um Estado estrangeiro, estrangeira é esta sentença. É a decisão emanada de uma soberania estrangeira." (SERPA LOPES, Miguel Maria de, Comentários à Lei de Introdução ao Código Civil, cit., v. 3, p. 207).

${ }^{238}$ FONSECA, José Roberto Franco da. Natureza e eficácia da sentença internacional. In: MERCADANTE, Araminta de Azevedo; MAGALHÃES, José Carlos de (Coords.). Solução e prevenção de litígios internacionais. Porto Alegre: Livraria do Advogado, 1999. v. 2, p. 87.
} 
internacional houver por bem lhe aplicar, em razão de descumprimento de obrigação caráter internacional. $^{239}$

Há, nessas hipóteses, uma atribuição de jurisdição internacional a uma corte judiciária. Pode ocorrer também, como visto acima, dessa jurisdição internacional ser atribuída ao Poder Judiciário de um Estado soberano mediante convenção ou tratado, como o foi através do Protocolo de Las Leñas. A jurisdição internacional atribuída ao Poder Judiciário dos Estados partes do Mercosul traz como consequência um efeito internacional-regional às suas sentenças.

Em todos esses casos, não há que falar em homologação da sentença internacional pelo Superior Tribunal de Justiça. Não se trata de cumprimento de sentença estrangeira proveniente de Poder Judiciário de Estado estrangeiro que, para ser executada em território nacional, deve passar pelo crivo das autoridades judiciárias brasileiras.

Note-se que caso a sentença seja proferida por um tribunal internacional do qual o país não faça parte ou não tenha acordado em submeter a ele o litígio, ainda que ele seja internacional, não estaremos diante de sentença internacional, mas sim de sentença estrangeira, que deverá observar o processo de homologação, para que no Brasil possa ser executada. No entanto, como bem explica José Carlos de Magalhães:

"Se o ato provier de corte internacional em processo de que o Brasil é parte, tendo-se comprometido, por isso, a cumprir a decisão que vier a ser proferida, tal sentença é internacional e seu cumprimento independe de homologação perante o Supremo Tribunal Federal, mesmo porque a Constituição não lhe confere tal competência, e sim a de homologar sentenças estrangeiras, com a qual não se confunde a sentença internacional." 240

Podemos citar como exemplo de cortes judiciárias que detêm jurisdição sobre o Brasil o Tribunal Arbitral do Mercosul, a Corte Interamericana de Direitos Humanos e o Tribunal Penal Internacional.

\footnotetext{
${ }^{239}$ MAGALHÃES, José Carlos de, op. cit., p. 102.

${ }^{240}$ MAGALHÃES, José Carlos de, O Supremo Tribunal Federal e o direito internacional: uma análise crítica, cit., p. 103.
} 


\subsection{Processo de Homologação. Requisitos}

O processo de homologação, diferentemente do processo de solução da controvérsia realizado perante tribunal estrangeiro, se destina a verificar se estão presentes todos os requisitos aos quais a lei condiciona a produção de efeitos executórios à sentença estrangeira. Em caso positivo, a sentença declara o direito do autor ao reconhecimento e a torna apta à instauração de um processo de execução perante o juízo federal competente.

É, portanto, distinto do processo desenvolvido no exterior, na medida que este traz pretensão relacionada à lide de direito material resolvida pela sentença estrangeira, enquanto o processo de homologação veicula a pretensão à homologação do julgamento estrangeiro. Nesse pedido reside o mérito do "juízo de delibação", totalmente distinto do mérito do processo estrangeiro.

As partes ingressam com o pedido diretamente no Superior Tribunal de Justiça, cabendo ao presidente examinar a inicial e verificar se todos os requisitos foram preenchidos. Dará, caso seja necessário, prazo ao requerente para emendar ou aditar o pedido, sob pena de indeferimento. Em seguida, intima-se o requerido, nomeando-se um curador especial, caso não seja encontrado para que apresente em quinze dias sua resposta. A contestação só versará sobre os requisitos formais e contrariedade à ordem pública e aos bons costumes, como estabelecido no artigo $9^{\circ}$, parágrafo $1^{0^{241}}$, da Resolução n. 9 do Superior Tribunal de Justiça.

O presidente do Superior Tribunal de Justiça pode homologar a decisão estrangeira por decisão monocrática, sujeita ao recurso de agravo regimental. Todavia, se a sentença estrangeira for contestada, cessa a sua competência e a ação será distribuída a um relator, ocasião na qual será julgada pela Corte Especial do Superior Tribunal de Justiça.

Os requisitos a serem atendidos se encontram na Lei de Introdução às Normas do Direito Brasileiro, artigos 15 e 17, e também na Resolução n. 9 do Superior Tribunal de Justiça, que substituiu o Regimento Interno do Supremo Tribunal Federal.

\footnotetext{
241 “Art. $9^{\circ}$ - Na homologação de sentença estrangeira e na carta rogatória, a defesa somente poderá versar sobre a autenticidade dos documentos, inteligência da decisão e observância dos requisitos desta resolução.”
} 
São pressupostos de homologabilidade da sentença estrangeira: a) a sua prolação por juiz competente; b) a citação do réu ou a configuração legal da revelia; c) o trânsito em julgado do ato sentencial homologando, bem o cumprimento das formalidades necessárias à sua execução no lugar em que foi proferido; d) a autenticação pelo consulado brasileiro da sentença homologanda e a tradução oficial dos documentos; e, e) não contrariedade à ordem pública e aos bons costumes.

\subsubsection{Competência do juiz prolator}

A aferição deste requisito se dá em observância às regras de competência internacional da autoridade judiciária brasileira analisadas no primeiro capítulo do presente trabalho. Não há exame das regras de competência interna da autoridade judiciária estrangeira segundo as leis do Estado a que está vinculada. Tal medida visa unicamente a aferir se não foi usurpada a competência exclusiva do juiz brasileiro prevista no artigo 89 do Código de Processo Civil; em caso positivo, a homologação será denegada.

\subsubsection{Citação válida do réu ou a configuração legal da revelia}

Este requisito busca aferir se houve observância do princípio do contraditório e da ampla defesa. A citação válida oportuniza à parte contrária a possibilidade de se defender, efetivando assim o contraditório e a garantia da ampla defesa, com o que se está observando o devido processo legal.

De acordo com a legislação vigente, a citação da parte domiciliada no Brasil para responder a processo que tramita em foro estrangeiro deve necessariamente se realizar por carta rogatória. Não se admite como válida a citação via autoridade consular. Há, no entanto, casos excepcionais, em que se admite o comparecimento espontâneo da parte no processo estrangeiro para se defender. ${ }^{242}$

Caso não se tenha êxito na citação por meio da carta rogatória da parte domiciliada em território nacional, há que se verificar se houve a citação por edital procedida pela autoridade

${ }^{242}$ STF - SE n. 7.178, 2004; STJ - AgR CR n. 3.306, 2008. 
judiciária estrangeira que, em caso positivo, torna válida a revelia verificada ${ }^{243}$. A constatação de que a revelia não se deu de forma válida acarretará a denegação da homologação, como por exemplo na SEC n. 6.729, de 2002 (STF), na qual a citação por edital da parte domiciliada no Brasil se deu apenas em território estrangeiro e não foi precedida da tentativa de citação por meio de carta rogatória.

Portanto, nas hipóteses em que o réu da sentença a ser homologada tenha ou teve domicílio na Brasil no momento em que deveria ter ocorrido a citação, o Superior Tribunal de Justiça verificará se a citação ocorreu nos moldes da legislação brasileira, tendo em vista ser esse o local onde a diligência deveria ter ocorrido. Caso não tenha ocorrido validamente, a homologação será denegada.

\subsubsection{Trânsito em julgado do ato sentencial homologando, bem o cumprimento das formalidades necessárias à sua execução no lugar em que foi proferido}

A exigência ${ }^{244}$ visa a comprovar a impossibilidade de modificação da sentença na jurisdição de origem. Nada obstante, tal orientação se encontra sumulada pelo Supremo Tribunal Federal. ${ }^{245}$

Pode causar certa dúvida a forma pela qual a parte requerente deve comprovar o trânsito em julgado da sentença estrangeira, na medida que tanto a Lei de Introdução, a Resolução n. 9 do Superior Tribunal de Justiça e o Código de Processo não especificam como deve ser realizada a prova.

Na SEC n. 911 de 2007, o Superior Tribunal de Justiça entendeu que "a prova do trânsito em julgado é matéria processual que varia em cada país, não se podendo exigir a mesma forma do direito brasileiro". Desse modo, devem-se avaliar as disposições do direito vigente no Estado em que foi prolatada. O trânsito em julgado, portanto, reflete a situação

\footnotetext{
${ }^{243}$ STF - SE 3.862, 1990.

${ }^{244}$ O Código Bustamante também prevê o requisito em seu artigo 423, n. 4: "Que seja exequível no Estado em que tiver sido proferida."

${ }^{245}$ Súmula n. 420 do STF: "Não se homologa sentença proferida no Estado estrangeiro sem prova do trânsito em julgado."
} 
jurídica de imutabilidade, de acordo com o direito local. Nadia de Araujo ${ }^{246}$ esclarece que o Supremo Tribunal Federal comprova o trânsito em julgado mediante declaração expressa do tribunal estrangeiro ou, na ausência de tal declaração, aplica os artigos 409 a 411 do Código Bustamante, que tratam das regras especiais sobre provas em leis estrangeiras.

Com relação às formalidades necessárias à sua execução no Estado em que foi proferida, significa que somente se outorga força executória à sentença que no seu Estado de origem seja válida e operante segundo suas regras.

\subsubsection{Autenticação pelo consulado brasileiro e tradução oficial dos documentos}

A sentença estrangeira deverá conter a chancela do consulado brasileiro do local onde foi prolatada. O cônsul brasileiro no exterior exerce funções notariais, incumbindo-lhe conferir valor ao documento oficial que se pretenda executar em território brasileiro.

Poderá dispensar a exigência de autenticação, caso a sentença estrangeira tramite por via diplomática, bem como nos casos em que houver regulamentação especial por tratados e convenções sobre o tema. ${ }^{247}$

A tradução para o idioma nacional deverá se dar por tradutor juramentado e se justifica, na medida que não é razoável exigir do julgador que conheça todos os idiomas ${ }^{248}$. Registre-se que deverá ocorrer no Brasil, pois a fé pública exigida é privilégio de tradutor público e juramentado. $^{249}$

\footnotetext{
246 ARAUJO, Nadia de (Coord.), Cooperação jurídica internacional no Superior Tribunal de Justiça: comentários à Resolução n. 9/2005, cit., p. 62.

${ }^{247}$ STF - SE n. 3.016, DJ, de 17.12.1982.

${ }^{248}$ STJ - SEC n. 2.052, 2008.

${ }^{249}$ ARAUJO, Nadia de (Coord.), op. cit., p. 66.
} 


\subsubsection{Não contrariedade à ordem pública, soberania nacional e aos bons costumes}

De difícil conceituação, a noção de ordem pública envolve um conjunto de princípios indispensáveis à organização da vida social, no qual se busca proteger valores como a moral, justiça, igualdade e segurança, que, segundo Jacob Dolinger ${ }^{250}$, refletem a filosofia social e política de uma nação prevalecente em determinado contexto sociocultural, político, econômico e jurídico de cada sociedade e em determinada época, e positivada em sua legislação. Como se vê, é ampla, portanto, a margem de valoração subjetiva conferida ao operador do direito para estabelecer um conceito de ordem pública, de modo que, para efeito da análise do dispositivo em questão, podemos incluir a soberania nacional e os bons costumes na noção de ordem pública. ${ }^{251}$

De acordo com Nadia de Araujo ${ }^{252}$, a ordem pública funciona como uma barreira à penetração de regras estrangeiras, mesmo que decorrentes da aplicação das regras de conexão de direito internacional privado, caso haja flagrante afronta aos direitos fundamentais que o direito interno visa a garantir e proteger. O Superior Tribunal de Justiça avaliará, assim, se houve violação à ordem pública nacional, sopesando os valores consagrados como basilares em nosso ordenamento jurídico.

Interessante caso de deferimento de homologação de sentença estrangeira se deu em uma sentença estrangeira proveniente dos Estados Unidos, na qual se notava a ausência de motivação (SEC n. 4.415, rel. Min. Francisco Rezek); o Supremo Tribunal Federal homologou a sentença, sob o argumento de que havia sido observada a legislação daquele país, que permitia a confecção do ato sentencial sem a fundamentação, não ferindo a ordem pública brasileira.

Interessante também a SEC n. 819, em que se pleiteou a homologação de uma sentença proveniente da França, que havia decidido sobre a guarda e visitação do filho brasileiro do casal. Havia sentença brasileira tratando da visitação, muito embora não tendo ainda transitado em julgado. O Superior Tribunal de Justiça entendeu a sentença francesa

\footnotetext{
${ }^{250}$ DOLINGER, Jacob, Direito internacional privado: parte geral, cit., p. 393.

${ }^{251}$ ARAUJO, Nadia de, Direito internacional privado: teoria e prática brasileira, cit., p. 343.

252 Ibidem, p. 112-135.
} 
contrária à soberania nacional, pelo fato da sentença brasileira ter decidido sobre a mesma situação. Nadia de Araujo ${ }^{253}$ afirma que nessa decisão o Superior Tribunal de Justiça manteve o entendimento do Supremo Tribunal Federal de dar prevalência às decisões nacionais, quando versasse matérias relacionadas a menores.

Como visto, de conceito fluido, a ordem pública figura como válvula de escape para sopesar valores jurídico, morais e socioeconômicos, no intuito de possibilitar ou negar, ainda que de forma indireta, a aplicação do direito estrangeiro em território nacional.

${ }^{253}$ ARAUJO, Nadia de, Direito internacional privado: teoria e prática brasileira, cit., p. 345. 


\section{CAPÍTULO III - LAUDO ARBITRAL ESTRANGEIRO}

\subsection{Histórico}

A arbitragem é mecanismo alternativo de solução de controvérsias que se realiza por meio da intervenção de terceiros, denominados árbitros, cujo poder de decidir decorre de uma convenção privada, e não do Estado, que objetiva a solução de litígios que envolvam direitos patrimoniais disponíveis.

Carlos Alberto Carmona, com exatidão, professa:

“[...] claro que a arbitragem é um mecanismo extrajudicial de solução de conflitos, de tal sorte que a intervenção do Poder Judiciário ou não existirá, ou então será invocada quando houver necessidade de utilizar a força diante da resistência de uma das partes ou de terceiros (condução de testemunhas, implementação de medidas cautelares, execução de provimentos antecipatórios ou execução de sentença arbitral)." ${ }^{254}$

Trata-se, portanto, de mecanismo privado de solução de litígios, no qual um terceiro escolhido pelas partes profere uma decisão que se impõe a elas. E isso a difere da conciliação e da mediação. A arbitragem visa à solução de um conflito de interesses por meio de uma solução imposta por um terceiro imparcial. Já a conciliação e a mediação buscam a celebração de um acordo. ${ }^{255}$

A arbitragem é tida como o meio alternativo de solução de conflitos, relacionados a litígios envolvendo direito privado, mais praticado no mundo ${ }^{256}$. Dentre seus atrativos, podemos citar o menor formalismo, o sigilo do procedimento arbitral e a celeridade, bem como e principalmente a qualidade da decisão, em decorrência do melhor domínio técnico que os árbitros detêm sobre o objeto da controvérsia.

\footnotetext{
${ }^{254}$ CARMONA, Carlos Alberto. Arbitragem e processo: um comentário à Lei n. 9.307/96. 2. ed. São Paulo: Atlas, 2004. p. 53. Demonstra-se, com isso, que o Estado, por meio do Poder Judiciário, coloca à disposição da arbitragem todo seu aparato de poder no intuito de fomentá-la e visando ao seu sucesso, o que não a torna, contudo, estatal.

${ }^{255}$ CARMONA, Carlos Alberto, op. cit., p. 51-53.

256 DOLINGER, Jacob; TIBURCIO, Carmen. Direito internacional privado (parte especial): arbitragem comercial internacional. Com a colaboração de Suzana Medeiros. Rio de Janeiro: Renovar, 2003. p. 49. Assim também, CARMONA, Carlos Alberto, op. cit., p. 23 e 208 et seq.
} 
Jacob Dolinger e Carmen Tiburcio ${ }^{257}$ ponderam que os juízes e os tribunais estatais, pelo fato de tratarem de uma diversidade de demandas, que vão desde conflitos de vizinhança à responsabilidade por exposição a material radioativo, dentre outros variados assuntos, compreensivelmente são em regra generalistas e não especialistas, como podem vir a ser o árbitro ou os árbitros escolhidos.

Há no mundo inúmeras e respeitadas instituições de arbitragem, dentre as quais podemos citar como exemplo a American Arbitration Association (AAA), a London Court of International Arbitration (LCIA) e a Câmara do Comércio Internacional (CCI), que com sua atuação buscam prestigiar o instituto que brevemente comentamos. ${ }^{258}$

Muito embora afirme parte da doutrina que a arbitragem não atingiu em nosso país o nível de importância de que desfruta em outros países desenvolvidos ${ }^{259}$, ela se mostra bastante encorajadora, sobretudo após o advento da Lei n. 9.307/96, e em face das mazelas encontradas no Poder Judiciário. Carmona ${ }^{260}$ pondera que o notório recrudescimento da crise do processo e do Poder Judiciário impulsionou significativamente o desenvolvimento da arbitragem entre nós. Observa ainda que "apesar das seguidas reformas implantadas no Código de Processo Civil estamos longe de obter um mecanismo judicial que possa ser considerado funcional e eficaz para resolver litígios" e que o "processo judicial continua a ser uma antevisão da eternidade".

A promulgação da Lei n. 9.307/96 foi um divisor de águas no desenvolvimento da arbitragem no território nacional. Trouxe decisivas inovações que superaram obstáculos de cunho jurídico tidos por desencorajadores da utilização do instituto entre nós. Aboliu-se a diferença havida com relação aos efeitos entre cláusula compromissória e compromisso arbitral, a necessidade de homologação do laudo nacional, para que só então pudesse se instaurar sua execução judicial, bem como o sistema dupla homologação do laudo arbitral estrangeiro.

Contudo, como observado acima, nem sempre foi assim. A distinção entre cláusula compromissória e compromisso arbitral, a necessidade de homologação do laudo nacional,

\footnotetext{
257 DOLINGER, Jacob; TIBURCIO, Carmen, Direito internacional privado (parte especial): arbitragem comercial internacional, cit., p. 49.

${ }^{258}$ Ibidem, mesma página.

${ }^{259}$ Ibidem, mesma página.

${ }^{260}$ CARMONA, Carlos Alberto, Arbitragem e processo: um comentário à Lei n. 9.307/96, cit., p. 18.
} 
bem como o sistema da dupla homologação do laudo arbitral estrangeiro sempre foram tidos como fatores desencorajadores da utilização do instituto no Brasil. ${ }^{261}$

A arbitragem já estava prevista na Constituição Política do Império de 1824. Nela vinha expressa a possibilidade de, via juízes árbitros, solucionarem-se litígios entre nacionais e estrangeiros, com a possibilidade, ainda, de se estabelecer a irrecorribilidade do laudo $\operatorname{arbitral}^{262}$. Vejamos seu artigo 160:

“Art. 160 - Nas cíveis e nas penaes civilmente intentadas poderão as partes nomear juízes árbitros. Suas sentenças serão executadas sem recurso, se assim o convencionarem as mesmas partes."

O Código de Comércio de 1850, bem como o Regulamento 737, do mesmo ano, estabeleciam como obrigatória a arbitragem entre comerciantes e, não querendo as partes se submeterem a árbitros, o juiz de direito do comércio deprecaria a demanda ao Tribunal do Comércio para a nomeação dos árbitros. Os dispositivos desse Regulamento foram revogados pela Lei n. 1.350 , de $14.09 .1866 .^{263}$

Primeiro diploma a disciplinar a cláusula compromissória, o Decreto n. 3.900, de 1867, foi o responsável, segundo Jacob Dolinger e Carmen Tiburcio ${ }^{264}$, por seu "esvaziamento" no direito brasileiro, tornando o compromisso arbitral o único instrumento eficaz à instauração da arbitragem. Seu artigo $9^{\circ}$ dispunha:

"Art. 90 - A cláusula compromissória, sem a nomeação de árbitros, ou relativa a questões eventuais não vale senão como promessa, e fica dependente para sua perfeição e execução de novo e especial acordo das partes, não só sobre os requisitos do art. $8^{\circ}$, senão também sobre as declarações do art. 10".

261 CARMONA, Carlos Alberto, Arbitragem e processo: um comentário à Lei n. 9.307/96, cit., p. 22-23; MARTINS, Pedro A. Batista; LEMES, Selma M.; CARMONA, Carlos Alberto. Aspectos fundamentais da Lei de Arbitragem. Rio de Janeiro: Forense, 1999. p. 15; DOLINGER, Jacob; TIBURCIO, Carmen, Direito internacional privado (parte especial): arbitragem comercial internacional, cit., p. 49; HUCK, Hermes Marcelo, Sentença estrangeira e lex mercatoria: horizontes e fronteiras do comércio internacional, cit., p. 71.

${ }^{262}$ MARTINS, Pedro A. Batista; LEMES, Selma M.; CARMONA, Carlos Alberto, op. cit., p. 15.

263 DOLINGER, Jacob; TIBURCIO, Carmen, op. cit., p. 20-21; MAGALHÃES, José Carlos de. Reconhecimento e execução de laudos arbitrais estrangeiros. Revista dos Tribunais São Paulo, Revista dos Tribunais, ano 86, v. 740, p. 119, jun. 1997. Jacob Dolinger e Carmen Tiburcio observam que no Brasil, até a edição da Constituição de 1891, não havia a tripartição de poderes, sendo que o Poder Moderador tinha legitimidade para intervir nos demais e, assim, não havia como identificar no Estado um ente que concentrasse a função jurisdicional, fato esse que contribuía para a aceitação da arbitragem como obrigatória (op. cit., p. 50).

${ }^{264}$ DOLINGER, Jacob; TIBURCIO, Carmen, op. cit., p. 21. 
A arbitragem vinha regulada no Código Civil de 1916 nos artigos 1.037 a 1.048, pelos Códigos de Processo Civil de 1939 nos artigos 1.031 a 1.046, e de 1973 nos artigos 1.072 a 1.102, este último revogado pela Lei n. 9.307/96 (Lei de Arbitragem). No entanto, nenhum desses diplomas tratava da cláusula compromissória.

Assim, até o advento da Lei n. 9.307/96, como se verá, a existência de uma cláusula compromissória prevendo que os litígios decorrentes de determinada relação jurídica deveriam ser submetidos à arbitragem não detinha a eficácia de instaurar o juízo arbitral. Tal resultado só era obtido com a celebração do compromisso arbitral.

José Carlos de Magalhães ${ }^{265}$, esclarecendo a distinção existente, definia da seguinte forma a cláusula compromissória:

\begin{abstract}
"Esta última (a cláusula compromissória) é a manifestação de vontade das partes em submeter à arbitragem a eventual controvérsia que surja de determinada relação jurídica de direito material que as vincula. Insere-se, portanto, em contrato que regula e tem por objeto principal relação jurídica de direito processual, com conteúdo e objetos próprios que não se confundem com as demais cláusulas do contrato."
\end{abstract}

Mais adiante, tratando do compromisso arbitral, definia que "o compromisso é contrato perfeito, que regula a instituição do juízo arbitral, com a nomeação dos árbitros, o estabelecimento das regras do procedimento a ser adotado ou a previsão da competência dos árbitros para definir tais normas".

Há que se fazer a ressalva, no entanto, ao Protocolo Relativo às Cláusulas Arbitrais, celebrado em Genebra, em $1923^{266}$, tido como a primeira convenção internacional a tratar exclusivamente da arbitragem comercial internacional ${ }^{267}$. Esse Protocolo, de acordo com doutrina autorizada, quando tratava das arbitragens internacionais, equiparava os efeitos da cláusula compromissória ao compromisso arbitral, conferindo eficácia à primeira, quanto à instituição do juízo arbitral. Defendia que nos contratos internacionais prescindia-se do ato

\footnotetext{
${ }^{265}$ MAGALHÃES, José Carlos de; BAPTISTA, Luiz Olavo. Arbitragem comercial. Rio de Janeiro: Freitas Bastos, 1986. p. 21 e 25.

${ }^{266}$ Decreto n. $21.187 / 32$.

267 HUCK, Hermes Marcelo, Sentença estrangeira e lex mercatoria: horizontes e fronteiras do comércio internacional, cit., p. 74.
} 
subsequente do compromisso, sendo apta a instituir, por si só, o juízo arbitral. ${ }^{268}$ Assim dispunha o artigo $1^{\circ}$ :

\begin{abstract}
"Art. $1^{\circ}$ - Cada um dos Estados contratantes reconhece a validade, entre as partes submetidas respectivamente à jurisdição de Estados contratantes diferentes, do compromisso ou da cláusula compromissória pela qual as partes num contrato se obrigam, em matéria comercial ou em qualquer outra suscetível de ser resolvida por meio de arbitragem por compromisso, a submeter, no todo ou em parte, as divergências que possam resultar de tal contrato, a uma arbitragem, ainda que esta arbitragem deva verificar-se num país diferente daquele a cuja jurisdição está sujeita qualquer das partes do contrato."
\end{abstract}

Merece também registro a Convenção Interamericana sobre Arbitragem Comercial Internacional do Panamá, de 1975, promulgada pelo Decreto n. 1.902, de 9 de maio de 1996. Essa Convenção equipara a cláusula compromissória nos contratos internacionais ao compromisso arbitral. Seu artigo $1^{\circ}$ estabelece:

“Art. $1^{\text {o }}$ - É válido o acordo das partes em virtude do qual se obrigam a submeter à decisão arbitral as divergências que possam surgir ou que hajam surgido entre elas com relação a um negócio de natureza mercantil."

Outro entrave apontado pela doutrina ${ }^{269}$ para desenvolvimento da arbitragem foi a necessidade de homologação judicial do laudo arbitral para se tornar executável. Tal fato se dava por imposição dos artigos 1.045 do Código Civil de $1916^{270}$, 1.042 do Código de Processo de $1939^{271}$ e 1.098 do Código de Processo de $1973 .{ }^{272}$

\footnotetext{
268 DOLINGER, Jacob; TIBURCIO, Carmen, Direito internacional privado (parte especial): arbitragem comercial internacional, cit., p. 30; MAGALHÃES, José Carlos de. A cláusula arbitral nos contratos internacionais. Revista de Direito Mercantil Industrial, Econômico e Financeiro, São Paulo, v. 43, p. 29-36, 1981; BAPTISTA, Luiz Olavo. A vida dos contratos internacionais. Tese (Professor Titular de Direito do Comércio Internacional) - Universidade de São Paulo, 1992. p. 133.

269 CARMONA, Carlos Alberto, Arbitragem e processo: um comentário à Lei n. 9.307/96, cit., p. 22-23; MARTINS, Pedro A. Batista; LEMES, Selma M.; CARMONA, Carlos Alberto, Aspectos fundamentais da lei de arbitragem, cit., p. 15; DOLINGER, Jacob; TIBURCIO, Carmen, op. cit., p. 49; HUCK, Hermes Marcelo, Sentença estrangeira e lex mercatoria: horizontes e fronteiras do comércio internacional, cit., p. 71.

270 “Art. 1.045 - A sentença arbitral só se executará, depois de homologada, salvo se for proferida por juiz de primeira ou segunda instância, como árbitro nomeado pelas partes.”

271 “Art. 1.042 - Será competente para a homologação do laudo arbitral o juiz a que, originariamente, competir o julgamento da causa."

272 "Art. 1.098 - É competente para homologação do laudo arbitral o juiz a que originariamente tocar o julgamento da causa."
} 
Após a homologação judicial, o laudo travestia-se de título executivo judicial, produzindo a partir de então os mesmo efeitos das sentenças estatais, conforme o artigo 584, inciso III, do Código de Processo de $1973 .{ }^{273}$

De acordo com o artigo 1.045, inciso VII, do Código de Processo de $1939^{274}$, o laudo arbitral não homologado em cinco dias, contados da prolação pelos árbitros, seria tido como nulo. Isso representava, nos dizeres de Hermes Marcelo Huck ${ }^{275}$, um flagrante intuito de submeter de imediato a decisão arbitral ao Poder Judiciário. Nada obstante, tal fato já revela, antes de mais nada, que o laudo não é sentença e nem poderia sê-lo.

Já na vigência do Código de Processo de 1973, o laudo arbitral deveria ser homologado em cinco dias; no entanto, não havia nulidade caso não o fizesse o interessado. As partes poderiam a qualquer tempo submeter o laudo à homologação, caso os árbitros ou o escrivão deixasse de submetê-lo à homologação no prazo de cinco dias. ${ }^{276}$

O laudo arbitral nacional devia, portanto, na vigência do Código de Processo de 1939 e do Código de Processo de 1973, até a edição da Lei de Arbitragem, ser homologado para autorizar um procedimento de execução, uma vez que a lei processual considerava a sentença homologatória de laudo arbitral título executivo judicial (art. 584, III, do CPC). Isso se dava tanto com o laudo nacional como com o estrangeiro, que devia ser homologado no país onde houvesse sido prolatado. Essa última exigência decorria apenas da jurisprudência do Supremo Tribunal Federal, vez que não havia disposição legal determinando a prévia homologação no país em que fosse proferido o laudo, para só então encontrar-se apto a ser submetido ao crivo do Supremo.

\footnotetext{
273 "Art. 584 - São títulos executivos judiciais: [...] III - a sentença homologatória de laudo arbitral, de conciliação ou de transação, ainda que esta verse questão posta em juízo". Esse dispositivo foi alterado inicialmente pela Lei n. 9.307/96 e, posteriormente, pela Lei n. 10.358/2001, que modificou o inciso III e acresceu o inciso VI (“a sentença arbitral”). O artigo 584 foi revogado pela Lei n. 11.232, de 22.12.2005, mantida sua vigência até 23.06.2006. Essa Lei alterou o sistema de execução do Código de Processo Civil, "transformando" a execução de título executivo judicial em uma fase do processo de conhecimento denominada cumprimento de sentença, prevista nos artigos 475 , I, e seguintes. O laudo arbitral é elencado, por força da Lei n. 9.307/96, como título executivo judicial no artigo 475-N, inciso IV, com a redação dada pela Lei n. 11.232, de 22.12.2005.

274 "Art. 1045. Será nula a decisão arbitral: [...] VII - quando o laudo não for depositado no prazo do art. 1.043.”; "Art. 1.043 - No prazo de cinco (5) dias, contados da data da assinatura, o laudo será depositado no cartório do juízo competente para a homologação."

${ }^{275}$ HUCK, Hermes Marcelo, Sentença estrangeira e lex mercatoria: horizontes e fronteiras do comércio internacional, cit., p. 69.

276 Ibidem, mesma página.
} 
$\mathrm{Na}$ realidade, nenhum dos diplomas legais, nem mesmo o Regimento Interno do Supremo Tribunal Federal, anteriores à Lei n. 9.307/96, distinguiam a arbitragem nacional da internacional. Quando se referiam à homologação do laudo arbitral, também não faziam distinção entre laudo nacional ou estrangeiro. Assim foram os artigos 59 e seguintes do Decreto n. 3.900, de 1867, 1.045 do Código Civil de 1916, 1.041 do Código de Processo Civil de 1939 e 1.098 do Código de Processo Civil de $1973 .^{277}$

Muito embora não houvesse nenhum dispositivo legal em vigor que determinasse a homologação de laudos arbitrais estrangeiros, o Supremo Tribunal Federal, em suposta coerência com o que ocorria no plano interno (no qual havia disposição expressa), apenas homologava os laudos arbitrais estrangeiros que houvessem sido homologados judicialmente no país em que foram proferidos. ${ }^{278}$

Muito embora Pimenta Bueno, em 1863, noticiasse que o governo do Brasil em 1846 havia concedido exequatur a um laudo arbitral proveniente da França sem qualquer formalidade, Jacob Dolinger ${ }^{279}$ esclarece que “aparentemente" essa linha jurisprudencial do Supremo Tribunal Federal teria sua origem no Decreto n. 6.982, de 1878, que em seu artigo 14 exigia a prévia homologação judiciária do laudo arbitral no país onde houvesse sido proferido:

"Art. 14 - As sentenças arbitrais estrangeiras uma vez que tenham sido homologadas por tribunais estrangeiros são suscetíveis de homologação pelo Supremo Tribunal Federal."

Curioso notar, entretanto, como já observado no capítulo anterior, que o Supremo Tribunal Federal não detinha à época a competência para homologar sequer sentenças estrangeiras, competência que adviria apenas com a Lei n. 221, de 1894. Vigorava, até então, para a execução de sentenças estrangeiras, o sistema do "cumpra-se", pelo qual o próprio juiz da execução, de modo incidental, examinava os requisitos previstos no referido Decreto n. 6.982 e autorizava a execução da sentença estrangeira, independentemente de qualquer

\footnotetext{
277 DOLINGER, Jacob; TIBURCIO, Carmen, Direito internacional privado (parte especial): arbitragem comercial internacional, cit., p. 20.

278 Ibidem, p. 25.

279 Ibidem, p. 25.
} 
processo formal de homologação. Esse sistema é tido por Vicente Greco Filho e por Haroldo Valladão $^{280}$ como um dos mais internacionalistas do mundo.

Nada obstante, tal fato demonstra a desconfiança reinante em nosso país com relação ao instituto da arbitragem, que culmina, a nosso ver, na inexplicável necessidade, sobretudo nos dias atuais, da chancela judicial a uma decisão privada de solução de controvérsia, simplesmente pelo fato de não ter sido proferida em território nacional.

Hermes Marcelo Huck ${ }^{281}$ afirma que a arbitragem sempre buscou se distanciar da Justiça estatal. E depender do Poder Judiciário para que o laudo tenha eficácia ou mesmo para a sua execução forçada representava uma fase patológica da arbitragem, situação que se agravava caso a execução fosse em Estado estrangeiro. Muito embora tenha escrito anteriormente à vigência da Lei n. 9.307/96, que fulminou o sistema da dupla homologação do laudo arbitral estrangeiro, remanesce ainda, por imposição legal que reputamos equivocada, a homologação pelo Superior Tribunal de Justiça, fato que a nosso ver representa resquício dessa patologia diagnosticada por Huck.

A Lei de Introdução ao Código Civil de 1916 não especificava a possibilidade de execução do laudo arbitral estrangeiro. O reconhecimento admitido pela Lei de Introdução restringia-se às sentenças dos tribunais estrangeiros, excluindo desse conceito laudos arbitrais proferidos no exterior. Seu artigo 16 dispunha: “As sentenças dos tribunais estrangeiros serão exequíveis, no Brasil, mediante as condições que a lei brasileira fixar."

A atual Lei de Introdução às Normas do Direito Brasileiro também não traz a hipótese de homologação de laudo arbitral estrangeiro. Seu artigo 15 determina: "Somente será executada no Brasil a sentença proferida no estrangeiro, que reúna os seguintes requisitos". E, na alínea "e", dispõe como requisito "ter sido homologada pelo Supremo Tribunal Federal".

Muito embora a redação seja clara quanto ao que se executa ser sentença, e desde que homologada, e não laudo homologado, nota-se a supressão da expressão tribunal estrangeiro,

\footnotetext{
${ }^{280}$ GRECO FILHO, Vicente, Homologação de sentença estrangeira, cit., p. 40. Também Haroldo Valladão admitia que o Decreto invocava princípios dos mais avançados. (Direito internacional privado, cit., v. 3, p. 186).

281 HUCK, Hermes Marcelo, Sentença estrangeira e lex mercatoria: horizontes e fronteiras do comércio internacional, cit., p. 70.
} 
de modo que tinha-se por abolida a necessidade de que a sentença tenha se originado de tribunal estrangeiro, fato que, nos dizeres de Hermes Marcelo Huck, admitiria a hipótese de execução do laudo estrangeiro. ${ }^{282}$

Esse autor afirma que muito embora se admitisse a hipótese do laudo arbitral estrangeiro se enquadrar na redação do artigo 15 de Lei de Introdução, o Supremo Tribunal Federal manifestou-se sobre a homologação de laudo arbitral estrangeiro apenas em 1958, ocasião em que exigiu que o laudo estrangeiro, para ser reconhecido e executado no Brasil, deveria ter sido homologado judicialmente no país de origem. ${ }^{283}$

A partir de então aumentou o número de laudos arbitrais proferidos fora do território nacional submetidos à homologação pelo Supremo Tribunal Federal, prevalecendo a exigência de prévia homologação no país de origem. ${ }^{284}$

Temos como exemplo a SE n. 2.597, proveniente do Reino Unido da Grã-Bretanha, que indeferiu a homologação do laudo arbitral pelo fato da decisão homologatória do laudo não ter sido proferida por órgão que detivesse poder de decidir em última instância. Jacob Dolinger afirma que a denegação da homologação nesse caso havia se dado também pelo fato de não restar comprovada de forma inequívoca a convenção de arbitragem e pela irregularidade da citação, vez que não havia sido realizada por carta rogatória da parte residente no Brasil. ${ }^{285}$

Do mesmo modo na SE n. 2.178 da República Federal da Alemanha, na qual o Ministro Antonio Neder declarou que o laudo arbitral, apenas se tivesse sido homologado pelo Judiciário do Estado em que se realizou a arbitragem, "merece ser havido como jurisdicional", e se tivesse conteúdo decisório seria uma sentença e poderia ser homologada pelo Supremo. Em que pese a orientação jurisprudencial da mais alta corte judiciária do país, o Ministro Antonio Neder parece concluir que se não houver homologação judicial do laudo arbitral, ele não merece ser havido como jurisdicional. Reputamos equivocado esse entendimento, na medida que o fato de ter sido o laudo homologado não atribui

\footnotetext{
282 HUCK, Hermes Marcelo, Sentença estrangeira e lex mercatoria: horizontes e fronteiras do comércio internacional, cit., p. 70.

283 Ibidem, p. 71.

284 DOLINGER, Jacob; TIBURCIO, Carmen, Direito internacional privado (parte especial): arbitragem comercial internacional, cit., p. 26-29 e 309 et seq.; HUCK, Hermes Marcelo, op. cit., p. 72.

${ }^{285}$ DOLINGER, Jacob; TIBURCIO, Carmen, op. cit., p. 317-318.
} 
jurisdicionalidade à arbitragem. Essa é uma de suas características. Parece confundir, o que também se nota com a Lei de Arbitragem, a origem do poder jurisdicional do árbitro, que não é a mesma do juiz togado. Assim, o fato de possuir dentre suas características a jurisdicionalidade, não o oficializa. Homologar o laudo no país de origem fazia com que o Supremo homologasse a sentença homologatória do laudo, pois para isso detinha competência.

Assim ocorreu na SE n. 1982 dos Estados Unidos da América, cujo relator, Ministro Thompson Flores, indeferiu a homologação pelo fato do laudo arbitral estrangeiro não ter sido homologado no país de origem. Ressalta-se no voto a natureza privada da arbitragem, que serviu para fundamentar o sistema de dupla homologação:

\footnotetext{
"Natureza do Órgão Arbitral - Em monografia intitulada El arbitraje em el derecho privado, o jurista mexicano Humberto Briseño Sierra assim justifica a existência de organismos internacionais privados como a American Arbitration Association: 'Las disputas provenientes de la interpretación de los términos de un contrato, de su cumplimiento o recisón, llegam a miles cada año, exponde la American Arbitration Association con sede en Nueva York. Los costos directos e indirectos de su arreglo exceden el monto del litígio frecuentemente y van acompañados de un rompimiento en las relaciones amistosas, por lo que los hombres de negocios y principales abogados han desarrollado un sistema comercial de arbitraje que propende hacia la justicia, la rapidez y la economia. Este sistema és administrado por la $A A A$, grupo voluntario que opera bajo las reglas de Nueva York sobre bases de no especulación, que mantienen su equipo en más de mil trescientas ciudades que sirvem práticamente todas las ares mercantiles de los Estados Unidos'.

A explicação do monografista revela que estamos diante de um órgão de natureza privada imaginado por razões de ordem prática, objetivando favorecer as relações mercantis no plano internacional.

Em que pese a tendência de prestigiar as decisões arbitrais - a obra citada refere ou transcreve vários convênios internacionais nesse sentido, entre os quais, o Protocolo e o Convênio de Genebra (1923 e 1927) - não se pode perder de vista que estamos examinando uma decisão de um organismo privado, num país que consagra como garantia dos cidadãos a tutela do Poder Judiciário (Constituição, artigo 153, § $4^{\circ}$ ).”
}

No entanto, havia nesse caso a possibilidade de homologação direta do laudo sem a homologação do Poder Judiciário do local onde o laudo fora emitido. O Ministro Thompson Flores fazia a ressalva em seu voto de que se houvessem sido provados teor e vigência do direito estrangeiro que dispensava a homologação judicial do laudo para que ele tivesse força executiva, poderia ser dispensada a homologação. Vejamos parte do voto: "Certo poderia ser examinada a hipótese de dispensar a homologação da Justiça americana, a que foi proferida 
pelo juízo arbitral. Era mister, todavia, que se fizesse prova do direito em questão, nos termos do art. 212 do CPC [...].”

Jacob Dolinger e Carmen Tiburcio ${ }^{286}$ afirmam que essa importantíssima ressalva não obteve a devida atenção da doutrina, sendo a jurisprudência do Supremo sempre vista como se exigisse sempre a homologação dos laudos arbitrais no Judiciário onde foram proferidos.

Dolinger e Tiburcio ${ }^{287}$, mais à frente, afirmam que o Supremo Tribunal Federal perdia a oportunidade de rever seu posicionamento na SEC n. 4.724-2 288 , na qual pretendia-se a homologação de laudo arbitral proferido pelo The Refined Sugar Association na Inglaterra, ocasião na qual havia prova de que o direito inglês não exigia a homologação do laudo. A homologação foi indeferida.

Por oportuno, transcrevemos as alegações da parte requerente da homologação direta sem a prévia homologação no Judiciário de origem:

"Ainda que não intimada para oferecer réplica, como determina o artigo 221, $\S 2^{\circ}$, do RISTF, a requerente, tomando conhecimento da impugnação da União e do parecer da PGR, ingressou com a petição de fl. 284, na qual sustenta:

'Quer para a lei brasileira, quer para a lei inglesa, juízes competentes podem ser também aqueles que proferem decisões arbitrais, como no caso da sentença cuja homologação se requer.

Consoante se lê do art. 1078 do capítulo XIV do Código de Processo Civil, que cuida do 'juízo arbitral'.

'O árbitro é juiz de fato e de direito e a sentença que proferir não fica sujeita a recurso, salvo se o contrário convencionarem as partes'.

Prosseguindo-se [...] nenhuma razão lhes assiste tampouco face aos termos do próprio art. 15 da Lei de Introdução ao Código Civil, na qual a requerida procura apoiar sua impugnação.

Com efeito, da letra 'c' do art. 15 da Lei de Introdução ao Código Civil, lêse: 'Art.15 - Será executada no Brasil a sentença proferida no estrangeiro, que reúna os seguintes requisitos: [...] c) ter passado em julgado e estar revestida das formalidades necessárias para execução no lugar em que foi proferida;'

A posição assumida pela requerida e pela Procuradoria representam um desrespeito à lei inglesa, que dispensa a homologação judicial da sentença arbitral.

\footnotetext{
${ }^{286}$ DOLINGER, Jacob; TIBURCIO, Carmen, Direito internacional privado: arbitragem comercial internacional, cit., p. 26 e 312.

${ }^{287}$ Ibidem, p. 313.

${ }^{288}$ No mesmo sentido: SE n. 2.006, SE n. 2.486-1, Inglaterra. Oportuno registrar que muitos desses julgados são encontrados em: DOLINGER, Jacob; TIBURCIO, Carmen, op. cit.; e VALLADÃO, Haroldo, Direito internacional privado, cit., v. 3.
} 
Impossível impor a outro país a adoção de uma formalidade não exigida em seu sistema legal, apenas para atender as exigências previstas em legislação estrangeira.

Dúvida não há, pois, de que a lei inglesa deve ser respeitada diante dos precisos termos do art. 15, letra c, da Lei de Introdução ao Código Civil.

$\mathrm{E}$, incontestavelmente, a lei inglesa dispensa a homologação judicial da sentença arbitral, proferida, no caso, em obediência ao contrato e às regras aplicáveis, como fazem prova os documentos anexos (doc. 1 e 2) e os demais já constantes dos autos. Ao apresentar, neste ato, a prova do direito estrangeiro citado (doc. 1) a requerente se antecipa à possível determinação de V. Exa, com base no disposto no artigo 337 do Código de Processo Civil [...].

Para repugnar a lei inglesa, como pretende a requerida, necessário seria que estivesse ela ofendendo a soberania nacional, a ordem pública e os bons costumes.

Neste caso, sim, aplicar-se-ia o art. 17 da Lei de Introdução [...].

Por fim, vale ressaltar que o relatório e o voto que se leem da Sentença Estrangeira n. 1982 - USA, transcritos pela requerida em sua contestação, só aproveitam à requerente." 289

O Ministro Sepúlveda Pertence entendeu que o laudo tal como apresentado não era suscetível de homologação pelo Supremo Tribunal Federal e votou pelo indeferimento da homologação. Como visto, esse era o entendimento, mesmo nos casos em que o país de origem não exigia a homologação judicial do laudo para que fosse executável. Dolinger e Tiburcio $^{290}$ afirmam que "o fundamento teórico de tal posição era de que o laudo arbitral não se equiparava à sentença judicial, e que somente as sentenças estrangeiras eram passíveis de homologação". De fato, laudo não é sentença, e o que o Supremo estava homologando não era o laudo arbitral propriamente dito, mas sim a sentença homologatória do laudo.

O sistema da dupla homologação, sobretudo nos casos em que países desconheciam o instituto da homologação do laudo arbitral, visto atribuírem eficácia direta ao laudo, independentemente de qualquer ato posterior do Poder Judiciário, inviabilizava a exigência feita pelo Supremo Tribunal Federal, além de colocar entraves ao desenvolvimento da arbitragem. Por outro lado, no entanto, tinha o efeito de fazer com que a doutrina buscasse maneiras de privilegiar e dar efetividade à arbitragem.

\footnotetext{
289 DOLINGER, Jacob; TIBURCIO, Carmen, Direito internacional privado (parte especial): arbitragem comercial internacional, cit., p. 313-314.

${ }^{290}$ Ibidem, p. 25.
} 
Coerentemente José Carlos de Magalhães ${ }^{291}$ criticava a posição do Supremo e defendia, à época, a apresentação direta do laudo ao juiz originariamente competente para conhecer da demanda que o homologaria e procederia à execução, uma vez que o artigo 1.098 não estabelecia distinção entre laudo nacional e estrangeiro, e o Supremo Tribunal Federal era competente tão somente para homologar sentenças estrangeiras, e laudos arbitrais não se enquadravam e não se enquadram automaticamente nesse conceito, visto não serem decisão judiciária.

Carlos Alberto Carmona, citado em parecer do Procurador Geral da República Geraldo Brindeiro no Agravo Regimental em SE n. 5.206-7, esclarecendo que o Supremo Tribunal Federal deixava claro que o laudo arbitral não é uma sentença, propunha a mesma solução de José Carlos de Magalhães. Vejamos:

"15. Por outro lado, o Professor Carlos Alberto Carmona, Professor de Direito Processual Civil da Faculdade de Direito da Universidade de São Paulo e da Universidade Mackenzie, faz as seguintes ponderações sobre o sistema de 'dupla homologação' de laudos arbitrais estrangeiros, in verbis: 'Como já se viu acima, o Supremo Tribunal Federal somente homologa sentenças estrangeiras que tenham, por sua vez, homologado laudos arbitrais nos seus respectivos países de origem. Dessa forma, mesmo que o laudo arbitral estrangeiro não esteja sujeito a homologação em seu país de origem, o Supremo Tribunal Federal tem ignorado o fato e exigido a homologação local prévia.

Este sistema penoso da 'dupla homologação' tem levado os juristas a procurar uma via alternativa àquela da homologação do laudo junto ao Supremo Tribunal Federal para a obtenção da efetividade do laudo no Brasil. E a solução que vem sendo cada vez mais discutida - mas que ainda não foi, ao que consta, experimentadas nos tribunais - é a de submeter o laudo estrangeiro ao mesmo regime homologatório dos laudos nacionais. Em outras palavras: a Constituição Federal determina ser competente o Supremo Tribunal Federal apenas para a homologação de sentenças estrangeiras. Ora, uma vez que o Tribunal em questão já deixou claro, em diversas oportunidades, que o laudo arbitral não é uma sentença (mesmo que a lei do local diga o contrário!), nada obsta que a parte interessada pretenda aplicar o artigo 1.098 do CPC, que determina ser competente para homologar o laudo (e a lei não discrimina se nacional ou estrangeiro) o juiz a que originariamente tocaria o julgamento da causa. Então, bastaria verificar, pelas regras de competência internacional inseridas no próprio Código, se o juiz brasileiro seria competente para julgar a causa que acabou sendo submetida aos árbitros (32); em caso positivo, com a aplicação das regras gerais de competência, chegar-se-ia ao juiz brasileiro competente para

\footnotetext{
${ }^{291}$ MAGALHÃES, José Carlos de. Perspectivas da arbitragem comercial no Brasil. Revista de Direito Mercantil, Industrial, Econômico e Financeiro, Nova Série, São Paulo, Malheiros, v. 27, n. 69, p. 24, jan./mar. 1988.
} 
homologar o laudo ...” (in Relatório sobre arbitragem internacional Relatório nacional: Brasil, 1996).,292

Em que pesem as críticas e sugestões da doutrina, o posicionamento do Supremo não se alterou. Desse modo, o laudo arbitral proferido fora do território nacional, para ser reconhecido e posteriormente executado no Brasil, deveria - salvo tratados e convenções internacionais com eficácia no ordenamento jurídico interno, cuja regra da especialidade lhes garantiriam a prevalência - observar os mesmos requisitos impostos para o reconhecimento de sentenças estrangeiras previstos no artigo 15 e 17 da Lei de Introdução (haver sido proferidas por juiz competente; terem sido as partes citadas ou haver-se legalmente verificado a revelia; terem passado em julgado e estarem revestidas das formalidades necessárias para a execução no lugar em que foram proferidas; estarem traduzidas por intérprete autorizado; terem sido homologadas pelo Supremo Tribunal Federal; não ofendessem a ordem pública, a soberania nacional e os bons costumes), bem como no artigo 483 do Código de Processo Civil, que remetia o processamento da homologação ao Regimento Interno do Supremo Tribunal Federal (arts. 215 e ss.), cujo artigo 17 também dispunha que a sentença estrangeira só produziria efeitos no Brasil depois de homologada pelo Supremo, com o acréscimo da sentença estrangeira haver sido autenticada pelo cônsul brasileiro.

Esse sistema era tido como desencorajador da utilização da arbitragem, a ponto de Hermes Marcelo Huck chegar a afirmar que essa dupla homologação:

"[...] transfigura a natureza do laudo arbitral. A chancela do Judiciário, ou
melhor, de ambos os judiciários, estrangeiro e brasileiro, retira da arbitragem
sua condição de decisão não judiciária. A homologação de laudo arbitral
previamente processado pelo tribunal do país de origem resulta em situação
na qual o Supremo Tribunal estaria reconhecendo a sentença estrangeira que
homologou o laudo arbitral, e não a decisão arbitral propriamente dita, em
flagrante desconsideração à emancipação e evolução da arbitragem
comercial internacional."

Oportuno o registro das convenções e tratados internacionais relacionados ao reconhecimento e execução dos laudos arbitrais estrangeiros. O Protocolo de Genebra de 1923, que versava sobre a arbitragem comercial internacional, consagrava em seu artigo $3^{\circ}$ :

292 DOLINGER, Jacob; TIBURCIO, Carmen, Direito internacional privado (parte especial): arbitragem comercial internacional, cit., p. 325-326.

${ }^{293}$ HUCK, Hermes Marcelo, Sentença estrangeira e lex mercatoria: horizontes e fronteiras do comércio internacional, cit., p. 71-73. 
“Os Estados contratantes se comprometem a assegurar a execução por suas autoridades, e de conformidade com as suas leis nacionais, de sentenças nacionais promulgadas em seus territórios."

Há que se mencionar ainda a Convenção Interamericana sobre Eficácia Extraterritorial das Sentenças e Laudos Arbitrais Estrangeiros de Montevidéu, de $1979^{294}$. Essa convenção trata do reconhecimento de laudos arbitrais proferidos no exterior, elencando os requisitos para a sua homologação.

\subsubsection{Lei de Arbitragem (Lei n. 9.307/96)}

Com o advento da Lei n. 9.307/96, o panorama da arbitragem no Brasil mudou. Marco histórico relativo ao desenvolvimento da arbitragem no Brasil, a Lei de Arbitragem pôs fim à distinção entre os efeitos da cláusula compromissória e o compromisso arbitral.

No sistema anterior à Lei de Arbitragem, mesmo quando avençada a cláusula compromissória entre as partes, a arbitragem esbarrava em sua ineficácia para instaurar o juízo arbitral, e mesmo quando instaurada a arbitragem com base na cláusula, frequentemente a parte vencida alegava a nulidade do laudo, por não ter sido firmado o compromisso arbitral, e isso desestimulava a adoção da via arbitral para a resolução de litígios.

Com a equiparação, a cláusula compromissória deixou de ser um pré-contrato de compromisso, de modo que tanto no plano interno como no internacional, tanto a cláusula compromissória quanto o compromisso arbitral excluem a jurisdição estatal, efeito obtido apenas, como visto, pelo compromisso arbitral. Tanto assim que a Lei tratou no mesmo capítulo da cláusula compromissória e do compromisso arbitral e passou a utilizar uma denominação comum para ambas: convenção de arbitragem. O artigo $3^{\circ}$ da Lei dispõe: “As partes interessadas podem submeter a solução de seus litígios ao juízo arbitral mediante a convenção de arbitragem, assim entendida a cláusula compromissória e o compromisso arbitral."

\footnotetext{
${ }^{294}$ Promulgada pelo Decreto n. 2.411, de 02.12.1997.
} 
Também com relação ao laudo arbitral, a lei inovou. A exigência da homologação do laudo arbitral nacional para que só então pudesse ser executado deixou de existir. A grande inovação vinha pela equiparação de coisas de naturezas distintas. Alterava-se inclusive a terminologia. O laudo passou a se denominar sentença.

Equiparou-se, por meio do artigo 31, o laudo arbitral à sentença judicial. O laudo arbitral passa a ter o mesmo status de sentença judicial no direito interno. Carlos Alberto Carmona $^{295}$ afirma que o legislador deliberadamente adotara "a tese da jurisdicionalidade da arbitragem, pondo termo à atividade homologatória do juiz, fator de emperramento da arbitragem". Estabelece o artigo 31:

"Art. 31 - A sentença arbitral produz, entre as partes e seus sucessores, os
mesmos efeitos da sentença proferida pelos órgãos do Poder Judiciário e,
sendo condenatória, constitui título executivo."

O artigo 41 da Lei incluiu o laudo arbitral dentre os títulos executivos judiciais, com a alteração introduzida no artigo 584, III, do Código de Processo, hoje artigo 475-N, inciso IV.

Reputamos equivocada a atitude do legislador. Em que pese o extraordinário avanço representado pela Lei n. 9.307/96, o árbitro já exercia atividade jurisdicional antes do advento da Lei. Essa é uma de suas inerentes características. Parece haver confusão quanto à origem do poder jurisdicional do árbitro, que não é a mesma do juiz togado. Assim, o fato de possuir dentre as suas características a jurisdicionalidade não torna o laudo arbitral um ato proveniente do poder jurisdicional do Estado. No entanto, abordaremos melhor o assunto no tópico seguinte.

Na mesma linha, o artigo 18 dispõe que o laudo, ou na terminologia da Lei a sentença arbitral, não mais se sujeitava a homologação pelo Poder Judiciário:

“Art. 18 - O árbitro é juiz de fato e de direito, e a sentença que proferir não fica sujeita a recurso ou a homologação pelo Poder Judiciário."

${ }^{295}$ CARMONA, Carlos Alberto, Arbitragem e processo: um comentário à Lei n. 9.307/96, cit., p. 45. 
José Carlos de Magalhães ${ }^{296}$ com razão criticou a atitude do legislador, ao tratar o laudo arbitral como título executivo judicial (art. 584, III, do CPC, alterado pelo art. 41 da Lei de Arbitragem). Na realidade, o laudo arbitral, pouco importe o rótulo que lhe seja conferido, não é título executivo judicial, mas extrajudicial. E, de acordo com o internacionalista, o legislador agiria melhor caso classificasse o laudo arbitral como título executivo extrajudicial, fato que não alteraria sua executoriedade e tampouco a regra que dispensa a homologação judicial, na medida que à época poderia ser executado com base no artigo 585, VII, do Código de Processo Civil que previa como título executivo extrajudicial "todos os demais títulos, a que, por disposição expressa, a lei atribuir força executiva".

No plano internacional, pode-se dizer que duas foram as principais alterações introduzidas pela Lei de Arbitragem, o fim do sistema da dupla homologação exigida para laudos proferidos fora do território nacional e a admissibilidade da via postal para citação de parte domiciliada no Brasil ${ }^{297}$. No entanto, esse último ponto será abordado quando comentarmos as hipóteses de indeferimento do pedido de homologação do laudo arbitral estrangeiro.

Em coerência com o que fez no plano interno, ao equiparar em efeitos o laudo arbitral a sentença judicial, outorgando-lhe o status de título executivo judicial, a Lei de Arbitragem, na medida que não mais fazia sentido equiparar laudo arbitral a sentença judicial no plano interno, e não conferir o mesmo tratamento ao laudo arbitral estrangeiro, mantendo a exigência de homologação pelo Poder Judiciário do país em que o laudo fosse proferido, no seu artigo 35 passou a dispensar a homologação do laudo arbitral estrangeiro pelo Poder Judiciário do país de origem, impondo apenas a sua prévia homologação, atualmente, pelo Superior Tribunal de Justiça, por força da Emenda Constitucional n. 45/2004, para possibilitar a instauração de um processo de execução contra a parte que resiste em cumprir o laudo. Vejamos:

“Art. 35 - Para ser reconhecida ou executada no Brasil, a sentença arbitral estrangeira está sujeita, unicamente, à homologação pelo Supremo Tribunal Federal."

\footnotetext{
${ }^{296}$ MAGALHÃES, José Carlos de, Reconhecimento e execução de laudos arbitrais estrangeiros, cit., p. 116-127.

${ }^{297}$ DOLINGER, Jacob; TIBURCIO, Carmen, Direito internacional privado (parte especial): arbitragem comercial internacional, cit., p. 37.
} 
A arbitragem passava, então, a ser um atrativo mecanismo de solução de controvérsias, deixando o arcaico sistema processual que emperrava o seu desenvolvimento no Brasil.

Digno de nota o fato do Congresso Nacional, mesmo após a edição da Lei de Arbitragem, ter aprovado e ratificado inúmeras convenções que tratam da matéria. Ratificou o Protocolo de Cooperação e Assistência Jurisdicional em Matéria Civil, Comercial, Trabalhista e Administrativa de 1992, conhecido como Protocolo de Lãs Leñas (Decreto 2.067, de 12/11/1996), como visto no capítulo anterior, o Acordo sobre Arbitragem Comercial Internacional do Mercosul de 1998 (Decreto n. 4.719, de 04/06/2003), o Acordo sobre Arbitragem Comercial entre Mercosul, Bolívia e Chile de 1998 (Dec. Leg. n. 483/2001). Ainda aprovou o Decreto n. 4.311, de 23 de julho de 2002, que ratificou e colocou em vigor entre nós a Convenção sobre o Reconhecimento e a Execução de Sentenças Arbitrais Estrangeiras, denominada Convenção de Nova Iorque de 1958.

Vigia, dentre a maioria dos países signatários da Convenção de Nova Iorque, o Protocolo de Genebra de 1923 sobre Cláusulas Arbitrais, cujo objetivo fora o de conferir compulsoriedade à cláusula arbitral, ratificado pelo Brasil e posto em vigor pelo Decreto n. 21.187, de 22 de março de 1932, e a Convenção de Genebra de $1927^{298}$, que tratava especificamente da execução de laudos arbitrais estrangeiros.

A Convenção de Nova Iorque de 1958 dispõe sobre as mesmas matérias das convenções acima mencionadas, assegurando a eficácia da convenção arbitral ${ }^{299}$ e também o reconhecimento e a validade dos laudos arbitrais confeccionados em territórios de outros países, e revogava, em seu artigo VII, 2, expressamente o Protocolo de Genebra de 1923 e a Convenção de Genebra de 1927, declarando que "cessarão seus efeitos dentre os Estados Contratantes, nos seus limites e para os de que venham a se vincular a esta Convenção".

\footnotetext{
${ }^{298}$ O Brasil não a ratificara.

${ }^{299}$ A Convenção dispõe, no artigo II, que os Estados signatários deverão reconhecer o acordo escrito, no qual se insere a cláusula arbitral (art. II, 2), pela qual as partes se comprometem a submeter a arbitragem as controvérsias que tenham surgido ou possam surgir da relação havida entre as partes. Desse modo, veio a reiterar o que já estava disposto nas Convenções de Genebra de 1923 e na Convenção Interamericana sobre Arbitragem Comercial Internacional do Panamá de 1975, que davam efetividade à cláusula compromissória para a instituição da arbitragem.
} 
O artigo I da Convenção delimita seu escopo, esclarecendo que ela se aplica ao reconhecimento e à execução de laudos arbitrais estrangeiros proferidos no território de um Estado que não o Estado em que se busque o reconhecimento e sua execução, decorrentes das controvérsias havidas entre pessoas físicas ou jurídicas.

Digno de nota é que o Brasil não fez qualquer ressalva quanto à sua aplicação, mas apenas quanto aos laudos oriundos dos Estados signatários, como lhe estava facultado pelo artigo I, n. 3. Essa disposição contém a regra de que no momento da assinatura, ratificação ou adesão à Convenção, o Estado poderia declarar que a aplicaria ao reconhecimento e à execução de laudos arbitrais proferidos apenas no território de outro Estado membro. Portanto, a Convenção está em vigor no Brasil em toda a sua abrangência, estabelecendo as normas para o reconhecimento e execução em território nacional tanto de laudos proferidos em territórios de Estados membros, como os proferidos em território de Estados não membros.

A sua entrada em vigor alterou a sistemática vigente entre nós em matéria de homologação de laudos arbitrais estrangeiros. Antes da ratificação, vigiam no Brasil diferentes sistemas para o reconhecimento e execução dos laudos arbitrais estrangeiros, dependendo da convenção ou tratado ratificado e aplicável à hipótese. Interessante quadro ilustrando situação estabeleceram Dolinger e Tiburcio. ${ }^{300}$

Para o laudo arbitral proferido no território de país não membro do Mercosul ou no de país não ratificante de convenções ratificadas pelo Brasil, deveriam ser observadas as hipóteses previstas nos artigos 38 e 39 da Lei de Arbitragem. Para os laudos proferidos no território dos países do Mercosul, deveriam ser observado os requisitos previstos no artigo 20 do Protocolo de Las Leñas. Para os laudos proferidos em território de país ratificante da Convenção Interamericana sobre Arbitragem Comercial Internacional de 1975 ou da Convenção Interamericana sobre Eficácia Extraterritorial de Sentenças e dos Laudos Arbitrais estrangeiros de 1979, deveriam ser observados os requisitos estipulados nos artigos $5^{\circ}$ ou $2^{\circ}$, respectivamente, das convenções. E o laudo arbitral proferido nos países em que se exige a homologação do Judiciário local para que tenha eficácia revela-se situação na qual o que se pretende no Brasil é a homologação de sentença judicial estrangeira, e não mais de laudo

\footnotetext{
${ }^{300}$ DOLINGER, Jacob; TIBURCIO, Carmen, Direito internacional privado (parte especial): arbitragem comercial internacional, cit., p. 42.
} 
arbitral estrangeiro, de modo que se impõe a observância dos requisitos previstos nos artigos 15 e 17 da Lei de Introdução às Normas do Direito Brasileiro. Como a Convenção de Nova Iorque está em vigor no Brasil em toda a sua abrangência, estabelecendo as normas para o reconhecimento e execução em território nacional tanto de laudos proferidos em territórios de Estados membros como os proferidos em território de Estados não membros, ela passa a reger o reconhecimento e execução de laudos arbitrais estrangeiros em território nacional.

\subsection{Natureza jurídica do laudo arbitral estrangeiro. O equívoco da lei}

Já foi dito acima que a arbitragem é mecanismo privado de solução de controvérsias que tem origem na vontade das partes, sendo, portanto, extrajudicial, ou, em outras palavras, com afastamento da intervenção do Estado, que envolve tão somente direitos patrimoniais disponíveis e que se realiza através da intervenção de terceiros (árbitros), cuja origem de seu poder de declarar o direito (jurisdição) decorre de uma convenção privada, e não por imposição do Estado, o que revela sua natureza privada. ${ }^{301}$

Pontes de Miranda ${ }^{302}$ afirma que ao formarem o compromisso arbitral, as partes renunciam à processualidade estatal. Haroldo Valladão ${ }^{303}$, ao tratar da arbitragem, refere-se a “juízes privados, de confiança direta das partes, os juízes árbitros, por elas próprias escolhidos", o que denota sua concepção sobre a natureza privada e a extrajudicialidade do mecanismo.

Hildebrando Accioly ${ }^{304}$, então consultor jurídico do Itamaraty, em parecer datado de 20 de junho de 1958 sobre projeto de convenção referente à execução de "sentenças arbitrais internacionais" visando a atender a uma solicitação do Secretário Geral das Nações Unidas para que os governos dos Estados membros lhes enviassem comentários ou sugestões a respeito da referida convenção, que viria a ser denominada Convenção de Nova Iorque, pouco antes de concluir seu parecer, no sentido de que "no Brasil a sentença arbitral estrangeira, em matéria de direito privado, só poderá ser cumprida se tiver sido homologada por juiz

\footnotetext{
${ }^{301}$ MAGALHÃES, José Carlos de, Reconhecimento e execução de laudos arbitrais estrangeiros, cit., p. 117-118. 302 PONTES DE MIRANDA, Francisco Cavalcanti. Tratado de direito privado. Rio de Janeiro: Borsoi, 1971. v. 26, § 3.181, p. 325.

${ }^{303}$ VALLADÃ O, Haroldo, Direito internacional privado, cit., v. 3, p. 210.

304 ACCIOLY, Hildebrando. Convenção sobre arbitragem comercial internacional. Revista de Mediação e Arbitragem, São Paulo, Revista dos Tribunais, ano 5, n. 18, p. 245, jul./set. 2008.
} 
competente, no país onde fora proferida, e, finalmente, receber aqui a homologação do Supremo Tribunal Federal", expressamente tomava como premissa o fato de que o julgamento arbitral, portanto o laudo, não constituía manifestação de autoridade judiciária, para que pudesse ser homologada pelo Supremo nos seguintes termos: "Mostrei, aliás, apoiado noutros juristas brasileiros, e até em juristas estrangeiros, que o julgamento arbitral, em matéria privada, não constitui manifestação de uma autoridade judiciária, que possa ser homologada pelo Supremo Tribunal Federal.”

Comungando a premissa acima, qual seja a de que o julgamento arbitral não constitui manifestação de autoridade judiciária, o Supremo Tribunal Federal, como já noticiado, sempre exigiu que o laudo arbitral estrangeiro, para ser reconhecido e executado no Brasil, deveria ter sido homologado judicialmente no país de origem. ${ }^{305}$

Desse modo, o que se homologava, até do advento da Lei de Arbitragem, em momento algum era o laudo arbitral estrangeiro, mas sim uma sentença, ato oficial de Estado estrangeiro que havia homologado o referido laudo arbitral.

É o que revela sua jurisprudência, sendo que alguns ministros declaravam expressamente que tal exigência se dava em razão da natureza privada do órgão arbitral e, consequentemente, da decisão por ele emitida.

Na SE n. 1.982, já citada, cujo relator foi o Ministro Thompson Flores, o Supremo indeferiu a homologação do laudo arbitral estrangeiro por não ter sido homologado no país de origem, deixando claro que o fizera com base na natureza privada da arbitragem:

\footnotetext{
"Em que pese a tendência de prestigiar as decisões arbitrais - a obra citada refere ou transcreve vários convênios internacionais nesse sentido, entre os quais, o Protocolo e o Convênio de Genebra (1923 e 1927) - não se pode perder de vista que estamos examinando uma decisão de um organismo privado [...]."'(grifamos).
}

\footnotetext{
305 CARMONA, Carlos Alberto, Arbitragem e processo: um comentário à Lei n. 9.307/96, cit., p. 47-48, 352358; MARTINS, Pedro A. Batista; LEMES, Selma M.; CARMONA, Carlos Alberto, Aspectos fundamentais da lei de arbitragem, cit., p. 15; DOLINGER, Jacob; TIBURCIO, Carmen, Direito internacional privado (parte especial): arbitragem comercial internacional, cit., p. 310-326; HUCK, Hermes Marcelo, Sentença estrangeira e lex mercatoria: horizontes e fronteiras do comércio internacional, cit., p. 71; MAGALHÃES, José Carlos de, Reconhecimento e execução de laudos arbitrais estrangeiros, cit., p. 116-121.
} 
Na SEC n. 4.724-2 (rel. Min. Sepúlveda Pertence), o Supremo Tribunal Federal teve a possibilidade de rever seu posicionamento e admitir a homologação direta do laudo estrangeiro, desde que provado teor e vigência do direito estrangeiro que dispensasse a homologação judicial do laudo. No entanto, não o fez. Indeferiu-a em razão ausência de homologação do laudo no país onde foi proferido. Nesta ocasião o Plenário do Supremo declarava que "a sentença estrangeira, susceptível de homologação no Brasil, não é o laudo do juízo arbitral ao qual, alhures, se tenham submetido as partes, mas sim a decisão do Tribunal judiciário ou órgão público equivalente que, no Estado de origem, o tenham chancelado, mediante processo no qual regularmente citada a parte contra quem se pretende, no foro brasileiro, tornar exequível o julgado". No mesmo sentido, SE n. 2.006, SE n. 2486-1 da Inglaterra, SE n. 2.178 da República Federal da Alemanha, dentre outras.

Haroldo Valladão ${ }^{306}$, ao comentar a jurisprudência do Supremo, assinala que ela seguia firme na orientação de denegar a "homologação de sentenças proferidas por juízo arbitral, órgão privado, sem homologação de qualquer tribunal judiciário ou administrativo no país de origem”. Mais a frente, com exatidão, professa:

\begin{abstract}
"Destarte os laudos arbitrais originados do estrangeiro e ali não judicialmente homologados são considerados contratos, equivalendo mesmo a uma transação, e se válidos segundo o DIP [...] ou seja segundo as nossas regras de conflitos produzirão os efeitos processuais de qualquer contrato no Brasil"
\end{abstract}

Portanto, a conduta do Supremo Tribunal Federal de exigir que o laudo fosse homologado no país de origem significa que o que se estava a homologar não era o laudo arbitral propriamente dito, mas sim a sentença homologatória do laudo, ato oficial de Estado, o que revela que o laudo não era sentença e, mais importante, que ele nada tinha de estatal, pois se o tivesse não precisaria da chancela do Poder Judiciário de origem. Não nos parece que com o passar dos anos sua natureza tenha se modificado.

A nosso ver, refletindo a plena consciência de que o laudo arbitral nada tem de estatal, Nadia de Araujo ${ }^{307}$ esclarece que pelo fato do laudo arbitral ser ato de natureza privada é que antes da Lei de Arbitragem "vigia no Brasil o sistema da dupla homologação, pelo qual

\footnotetext{
${ }^{306}$ VALLADÃO, Haroldo, Direito internacional privado, cit., v. 3, p. 217.

307 ARAUJO, Nadia de (Coord.), Cooperação jurídica internacional no Superior Tribunal de Justiça: comentários à Resolução n. 9/2005, cit., p. 37-38.
} 
qualquer laudo proferido fora dos limites territoriais brasileiros, para ser delibado, devia ser previamente homologado pelo Poder Judiciário do país de origem", esclarecendo que "desse modo, a análise para a homologação recaía não sobre a decisão arbitral em si, e sim sobre a decisão judicial de origem".

Tanto é assim que Carlos Alberto Carmona, no já citado parecer do Procurador Geral da República Geraldo Brindeiro no Agravo Regimental em SE n. 5.206-7, procurava solucionar os entraves criados pelo o sistema da dupla homologação alegando que o Supremo Tribunal Federal homologava tão somente sentença homologatória de laudo arbitral, posto que laudo não era sentença.

Muito embora já exposto acima, merecem registro, uma vez mais, os ensinamentos de Carlos Alberto Carmona:

"[...] claro que a arbitragem é um mecanismo extrajudicial de solução de conflitos, de tal sorte que a intervenção do Poder Judiciário ou não existirá, ou então será invocada quando houver necessidade de utilizar a força diante da resistência de uma das partes ou de terceiros [...]." ${ }^{308}$

Trata-se indiscutivelmente de mecanismo privado, extrajudicial portanto, de solução de litígios, no qual um terceiro escolhido pelas partes por meio de um contrato profere uma decisão sobre a controvérsia havida. Naturalmente o seu resultado, o laudo arbitral, não poderia ter outra natureza que não a privada, contratual. Não foi essa a conduta adotada pelo legislador.

Em coerência com o que equivocadamente fez no plano interno, ao equiparar em efeitos laudo arbitral à sentença judicial, determinado no artigo 31 que "a sentença arbitral produz, entre as partes e seus sucessores, os mesmos efeitos da sentença proferida pelos órgãos do Poder Judiciário e, sendo condenatória, constitui título executivo" e no seu artigo 41 alterando o artigo 584 do Código de Processo Civil, para nele fazer contar que também é título executivo judicial a sentença arbitral (inc. III), a Lei de Arbitragem, na medida que não mais fazia sentido equiparar laudo arbitral à sentença judicial no plano interno e não conferir o mesmo tratamento ao laudo arbitral estrangeiro, mantendo a exigência de homologação no

\footnotetext{
${ }^{308}$ CARMONA, Carlos Alberto, Arbitragem e processo: um comentário à Lei n. 9.307/96, cit., p. 53.
} 
Poder Judiciário do país em que o laudo fosse proferido, em seu artigo 35 veio a selar essa equivocada coerência.

“Art. 35 - Para ser reconhecida ou executada no Brasil, a sentença arbitral estrangeira está sujeita, unicamente, à homologação pelo Supremo Tribunal Federal."

Por oportuno, de início cabe registrar que, de acordo com o artigo 35 da Lei de Arbitragem, e com a jurisprudência dos nossos tribunais ${ }^{309}$, o laudo arbitral proferido em território estrangeiro deve ser homologado pelo Superior Tribunal de Justiça ${ }^{310}$ para que só então se mostre apto a autorizar a instauração de um processo executivo.

Não se diz com isso que a Lei de Arbitragem agiu sem equívoco, ao equiparar o laudo arbitral à sentença judicial, incluindo-o no rol dos títulos executivos judiciais. São coisas completamente distintas. Erro grave cometeu o legislador. Não nos parece tenha a lei o condão de alterar a natureza das coisas.

Sobre o ponto em questão, José Carlos de Magalhães ${ }^{311}$ professa com exatidão que "o laudo arbitral não é título executivo judicial, mas extrajudicial, pois proferido por árbitro, pessoa privada, não integrante do Poder Judiciário, nem a ele equiparado ou equiparável”. $\mathrm{O}$ fato de atribuir-lhe os mesmos efeitos de uma sentença, ato oficial, e fazer constar no artigo 584, III, do Código de Processo Civil, atualmente artigo 475-N, inciso IV (“a sentença arbitral"), o laudo arbitral como título executivo judicial, não lhe atribui natureza diversa ou mesmo lhe altera a essência.

Note-se que os demais títulos executivos judiciais que constavam, à época, do artigo 584 do Código de Processo Civil, e atualmente constam do artigo 475- $\mathrm{N}^{312}$, são todos

\footnotetext{
${ }^{309}$ Essa é a orientação do Supremo Tribunal Federal e do Superior Tribunal de Justiça, agora competente para homologar laudos arbitrais estrangeiros. Nada obstante, como se verá quando tratamos da Convenção de Nova Iorque e seus efeitos sobre a Lei de Arbitragem, entendemos que o artigo 35 da Lei foi derrogado pela Convenção, em vigor entre nós, por ser com ela incompatível.

${ }^{310}$ Emenda Constitucional n. 45/2004.

${ }^{311}$ MAGALHÃES, José Carlos de, Reconhecimento e execução de laudos arbitrais estrangeiros, cit., p. 117.

312 "Art. 475-N - São títulos executivos judiciais: I - a sentença proferida no processo civil que reconheça a existência de obrigação de fazer, não fazer, entregar coisa ou pagar quantia; II - a sentença penal condenatória transitada em julgado; III - a sentença homologatória de conciliação ou de transação, ainda que inclua matéria não posta em juízo; IV - a sentença arbitral; V - o acordo extrajudicial, de qualquer natureza, homologado judicialmente; VI - a sentença estrangeira homologada pelo Superior Tribunal de Justiça; VII - o formal e a certidão de partilha, exclusivamente em relação ao inventariante, aos herdeiros e aos sucessores a título singular ou universal."
} 
decorrentes do Poder Judiciário. São sentenças judiciais ou condenatórias (incs. I e II) ou homologatórias e constitutivas (incs. III, V e VI) ou simplesmente homologatórias (inc. VII). Todos atos oficiais de Estado.

Magalhães ${ }^{313}$ qualifica como grave a confusão. De fato, a lei parece desconsiderar que a arbitragem, como exposto, é mecanismo privado, extrajudicial, de solução de litígios que tem origem num contrato no qual um terceiro escolhido pelas partes profere uma decisão sobre a controvérsia havida sobre esse mesmo contrato, sem intervenção do Poder Judiciário, a menos que solicitado para o uso da força. ${ }^{314}$

Carlos Alberto Carmona ${ }^{315}$, justificando a conduta do legislador ao equiparar laudo arbitral à sentença judicial, fazendo constar o laudo arbitral no rol dos títulos executivos judiciais, afirma que a equiparação se deu em razão da adoção da tese da jurisdicionalidade da arbitragem. Ocorre que essa característica lhe é inerente e preexistia à edição da Lei n. 9.307/96. Não nos parece tenha a lei atribuído jurisdicionalidade à arbitragem ${ }^{316}$. Não obstante, essa característica não altera sua natureza contratual e tampouco torna o laudo ato oficial. Em outras palavras, o fato do árbitro exercer atividade jurisdicional não empresta ao laudo o atributo da oficialidade.

Não se nega, ao contrário, se reconhece que há similitude entre os dois mecanismos de solução de litígios. Tanto quanto no processo judicial, o juiz esgota sua competência ao proferir a sentença, o árbitro, no procedimento arbitral, ao proferir o laudo perde sua jurisdição. Assim, tanto o laudo como a sentença põem fim ao litígio sobre o direito controvertido.

Há jurisdicionalidade seja no processo judicial seja no procedimento arbitral. Ambos, árbitros, pessoas naturais despidas de qualquer autoridade pública, e juízes togados, exercem

\footnotetext{
${ }^{313}$ MAGALHÃES, José Carlos de, Reconhecimento e execução de laudos arbitrais estrangeiros, cit., p. 117.

314 ACCIOLY, Hildebrando, Convenção sobre arbitragem comercial internacional, cit., p. 245; CARMONA, Carlos Alberto, Arbitragem e processo: um comentário à Lei n. 9.307/96, cit., p. 53; MAGALHÃES, José Carlos de, op. cit., p. 117; PONTES DE MIRANDA, Francisco Cavalcanti, Tratado de direito privado, cit., v. 26, § 3.181, p. 325; VALLADÃO, Haroldo, Direito internacional privado, cit., v. 3, p. 210.

${ }^{315}$ CARMONA, Carlos Alberto, op. cit., p. 45 . O autor afirma que a atividades dos árbitros são em tudo e por tudo idênticas às do juiz togado, e por isso a equiparação feita pela lei. Entende que nem só o árbitro exerce atividade jurisdicional, embora afirme que a arbitragem tem natureza jurisdicional (Ibidem, p. 229-238).

316 Jacob Dolinger e Carmen Tiburcio entendem o contrário. Afirmam que a equiparação havida entre laudo e sentença está em consonância com a natureza jurisdicional conferida à arbitragem pela Lei n. 9.307/96 (Direito internacional privado (parte especial): arbitragem comercial internacional, cit., p. 33-37, 301-306).
} 
jurisdição. A jurisdição é função não exclusivamente exercida pelo Estado, embora seja por ele essencialmente exercida.

A característica jurisdicional da arbitragem, qual seja de compor um conflito de interesses sobre direitos patrimoniais disponíveis, se mostra tão mais relevante, diante do fato de que o próprio Estado, por meio de seu poder jurisdicional, lhe dá subsídios para que se realize a contento e de forma eficaz. O Estado prestigia essa sua característica e lhe dá importância. Coloca sua estrutura de poder à disposição da arbitragem, seja para assegurar a produção de provas, seja para a concessão de medidas cautelares a pedido dos árbitros, seja para a realização de atos que os árbitros considerem indispensáveis à instrução do procedimento arbitral e à apuração dos fatos. O Poder Judiciário pode ser acionado pelos árbitros ou pelas partes. O Estado assim o faz com claro objetivo de dar valor a tal mecanismo extrajudicial de solução de controvérsias e, consequentemente, objetivando a eficácia do laudo arbitral, uma vez proferido. ${ }^{317}$

O fato de colocar seu arsenal de poder estatal à disposição dos árbitros, ou mesmo das partes do procedimento arbitral, não significa que o Estado também não tenha interesse que outros contratos privados se concretizem e se realizem sem, contudo, que deles decorram controvérsias que resultem em potenciais demandas judiciais, ou mesmo execuções de títulos extrajudiciais. E se litígios houver, também colocará seu arsenal de poder à disposição desses jurisdicionados.

O Estado tem interesse que os jurisdicionados realizem seus objetivos, seja por meio de contratos, seja por qualquer outro meio lícito, sem que seja necessária uma intervenção estatal, da mesma maneira que lhe interessa o desenvolvimento do procedimento arbitral, cuja consequência é, a princípio, um eficaz laudo arbitral.

Esse inquestionável interesse que o Estado detém na adoção arbitragem e que se revela no suporte prestado ao próprio procedimento arbitral visando à sua adequada conclusão, não a torna estatal ou mesmo oficial, a ponto de seu resultado, o laudo arbitral, por esse motivo, deter a mesma natureza e, naturalmente, a mesma força e atributos que uma decisão

\footnotetext{
317 HUCK, Hermes Marcelo, Sentença estrangeira e lex mercatoria: horizontes e fronteiras do comércio internacional, cit., p. 68.
} 
proveniente de um poder jurisdicional, enquanto função de poder estatal. Inegavelmente, não há na arbitragem o exercício de uma função de poder estatal.

Ocorre que não se pode desconsiderar, e nos parece tenha sido esse o equívoco do legislador, que a jurisdição do árbitro tem origem distinta da do juiz togado.

A jurisdição - entendida como poder de declarar e tornar efetivo o direito - não é originária do Estado. Consequência disso é que nem toda decisão, entendida como atividade jurisdicional, detém os mesmos atributos, efeitos e consequências de uma decisão ou ordem estatal, especialmente quando não cumprida.

O Estado nada mais é do que uma entidade constituída pela comunidade nacional povo e nação - que lhe delegou poderes e, assim, jurisdição - entendida como o poder de declarar o direito - sendo imprescindível que os seus atos traduzam aspirações, valores e princípios eleitos pela comunidade que o constituiu, sob pena de tornar-se com ela incompatível. $^{318}$

Não pode assim o Estado, por meio de seus governos, ignorar os valores e os princípios eleitos pela comunidade nacional e dela imanentes. José Carlos de Magalhães ${ }^{319}$, em explanação sem reparos, explica:

"Isto porque os indivíduos que formam as comunidades nacionais - o povo,
ou a nação - é que detêm a jurisdição originária, entendida como autoridade
para declarar o direito, delegando-a à entidade por eles criada para
coordenar-lhes as atividades e organizar os serviços de interesse comum. Em
outras palavras, é o povo que outorga ao Estado autoridade para declarar e
tornar efetivo o Direito nas órbitas internas e internacional. A autoridade do
Estado, portanto, é sempre delegada, não originária, pois a Constituição nada
mais é senão o instrumento que lhe confere essa autoridade - a jurisdição,
como poder de declarar o Direito - em nome da comunidade, que a possui
originariamente."

A Constituição precede ao Estado que a ela deve observância, inclusive e sobretudo quando, por meio do processo legislativo, formula sua leis, como a que ora comentamos. $\mathrm{Na}$ realidade, "a Constituição é uma coisa antecedente ao governo, e um governo é somente uma

\footnotetext{
${ }^{318}$ MAGALHÃES, José Carlos de, O Supremo Tribunal Federal e o direito internacional: uma análise crítica, p. 29.

${ }^{319}$ Ibidem, p. 33.
} 
criatura da Constituição. A Constituição de um país não é um ato de seu governo, mas do povo que constitui seu governo". 320

Magalhães ${ }^{321}$ afirma que a noção de que é o povo que detém a jurisdição, delegando-a ao Estado, foi o ideal que inspirou a Constituição dos Estados Unidos e está representado na Emenda X, que assim dispõe: "Os poderes não delegados aos Estados Unidos pela Constituição, nem proibidos por elas aos Estados, são reservados aos Estados, respectivamente, ou ao povo".

Todas as Constituições brasileiras exprimem esse ideal. A primeira Constituição do Brasil, não obstante aprovada no regime imperial em 1824, sofria influência dos ideais da Revolução Francesa. A Constituição não escrita da Inglaterra modificava a concepção de que os poderes do rei ou do imperador advinham de Deus por direito divino, e passava a condicionar o poder do rei à vontade da nação. ${ }^{322}$

Em razão dessas influências, o artigo $1^{\circ}$ da Constituição de 1824 declarava que "o Império do Brasil é associação política de todos os cidadãos brasileiros", numa clara demonstração de que foram os cidadãos brasileiros que organizaram o Estado sob forma de Império e não de República. No seu artigo 12, dispunha que "todos os poderes do Império do Brasil são delegações da nação". Por seu turno, o artigo 98 dispunha que "o poder moderador é a chave de toda organização política e é delegado privativamente ao Imperador". Assim também o artigo 13: "O poder legislativo é delegado à assembleia geral com a sanção do Imperador”. Magalhães ${ }^{323}$ bem pondera que até a entronização do Imperador havia sido estabelecida pela nação e não por poder divino. É o que se lê do artigo 116: "O Sr. D. Pedro I, por unânime aclamação dos povos, atual Imperador Constitucional e Defensor Perpétuo, imperará sempre o Brasil."

Nítida, portanto, a ideia de delegação de poder pela nação já na Constituição do Império.

\footnotetext{
${ }^{320}$ PAYNE, Thomas. The rights of men. Newark, Conn.: Eastern Press. Collector's Edition. p. 42.

${ }^{321}$ MAGALHÃES, José Carlos de, O Supremo Tribunal Federal e o direito internacional: uma análise crítica, p. 35.

${ }^{322}$ Ibidem, p. 33.

${ }^{323}$ Ibidem, p. 34.
} 
A Constituição de 1891, embora menos explícita, declarava que a nação brasileira, por seus representantes, adotava como forma de governo a República Federativa sob regime representativo $\left(\operatorname{art} .1^{\circ}\right)$.

A Constituição de 1934, mais explícita, em seu artigo $2^{\circ}$ dispunha que "todos os poderes emanam do povo e em nome dele serão exercidos".

A Constituição outorgada de 1937, em seu artigo $1^{\circ}$, repetia: “O Brasil é uma República. O poder político emana do povo e é exercido em nome dele e no interesse de seu bem estar, da sua honra, da sua independência e da sua prosperidade."

A Constituição de 1946 reiterava que "todo poder emana do povo e em seu nome será exercido". A Constituição outorgada por força do regime militar em 1967, bem como sua emenda de 1969 , mantiveram o preceito de que todo poder emana do povo. ${ }^{324}$

E, por fim, a atual Constituição (1988) dispõe em seu artigo $1^{\circ}$, parágrafo único, que "todo poder emana do povo, que o exerce por representantes eleitos ou diretamente, nos termos desta Constituição".

A nação, por outro lado, estabeleceu restrições e limitações a essa delegação de poderes, na medida que reservou para si a autoridade exclusiva de decidir sobre determinadas matérias. É o que ocorre, por exemplo, com a limitação dos poderes do Congresso Nacional para modificar a Constituição, nas hipóteses do parágrafo $4^{\circ}$ do artigo $60^{325}$. A comunidade nacional, o povo, reservou para si a competência exclusiva de deliberar sobre as hipóteses previstas nesse artigo, de modo que somente uma assembleia nacional constituinte estabelecida para esse fim pode deliberar e modificar esses preceitos constitucionais mantidos sob jurisdição exclusiva do povo.

Além dessas restrições podemos citar outras, como as encontradas no artigo 19, também da Constituição Federal, no qual consta a proibição para a União, Estados e

\footnotetext{
${ }^{324}$ MAGALHÃES, José Carlos de, O Supremo Tribunal Federal e o direito internacional: uma análise crítica, cit., p. 36.

325 “Art. 60 - A Constituição poderá ser emendada mediante proposta: [...] § $4^{\circ}$ - Não será objeto de deliberação a proposta de emenda tendente a abolir: I - a forma federativa de Estado; II - o voto direto, secreto, universal e periódico; III - a separação dos poderes; IV - os direitos e garantias individuais."
} 
Municípios de estabelecer cultos religiosos, bem como de criar dificuldades para o seu funcionamento ou de manter com eles ou com seus representantes relações de dependência ou aliança, ressalvada a colaboração do interesse público.

Essas restrições só ressaltam ser a jurisdição originária do povo e o caráter delegado da jurisdição outorgada aos órgãos do Estado. ${ }^{326}$

A nação é que detém, portanto, o poder, a autoridade para declarar direito e, assim, a jurisdição, delegando-a aos órgãos centrais do Estado que, como visto, não age em nome próprio, e sim no da comunidade que o organizou. O povo detém a jurisdição originária e a autoridade estatal, seja ela executiva, legislativa ou jurisdicional, exerce jurisdição delegada. $^{327}$

A Constituição é, ou menos supõe-se que tenha sido, concebida como unidade que expressa os valores permanentes da comunidade nacional centralizada no Estado, delegandolhe poderes para declarar e tornar efetivo o direito.

Muito embora tenha concentrado no Estado o exercício da jurisdição delegada, como é exemplo a jurisdição do juiz togado, a nação reservou para si também, em caráter concorrente, não exclusivo, algumas situações em que os indivíduos a exercerão concorrentemente ao Estado. E alguns dispositivos legais demonstram que houve a preservação do exercício desse poder originário, não delegado totalmente ao Estado.

O artigo $301^{328}$ do Código de Processo Penal estipula que qualquer do povo poderá cessar a liberdade da pessoa que seja encontrada em flagrante delito.

O Código Penal estabelece em seus artigos 24 e 25 hipóteses em que o indivíduo exerce originariamente o poder de declarar e tornar efetivo o direito sem que incorra em

\footnotetext{
${ }^{326}$ MAGALHÃES, José Carlos de, O Supremo Tribunal Federal e o direito internacional: uma análise crítica, cit., p. 37.

${ }^{327}$ Ibidem, p. 36.

328 "Art. 301 - Qualquer do povo poderá e as autoridades policiais e seus agentes deverão prender quem quer que seja encontrado em flagrante delito."
} 
prática criminosa ${ }^{329}$. O artigo $24^{330}$ trata da legítima defesa e o $25^{331}$ trata do estado de necessidade.

Em todos esses casos é o próprio indivíduo, e não a autoridade pública, que declara e torna efetivo o direito. Dispensa-se a participação da autoridade delegada. Especificamente nas hipóteses de legítima defesa e estado de necessidade, é o cidadão, comum do povo que, na situação de emergência, avalia e declara qual bem deve ser preservado e qual deve ser preterido.

Assim também na área do direito civil e do processo civil, dos quais constituem exemplos os artigos 1.210, parágrafo $1^{0332}, 1.283^{333}, 1.467^{334}, 1.469^{335}$ e $1.470^{336}$ Código Civil e $935^{337}$ do Código de Processo Civil.

O indivíduo, nesses casos, declara a direito aplicável ao fato concreto e o torna efetivo até com o uso da força, sem se socorrer do Estado. Atua legitimamente na sua condição de autoridade originária e no exercício de jurisdição concorrente à delegada ao Estado. ${ }^{338}$

329 “Art. 23 - Não há crime quando o agente pratica o fato: I - em estado de necessidade; II - em legítima defesa; III - em estrito cumprimento do dever legal ou no exercício regular de direito.”

330 “Art. 24 - Considera-se em estado de necessidade quem pratica o fato para salvar de perigo atual, quem não provocou por sua vontade, nem podia de outro modo evitar, direito próprio ou alheio, cujo sacrifício, nas circunstâncias, não era razoável exigir-se."

331 "Art. 25 - Considera-se em legítima defesa quem, usando moderadamente dos meios necessários, repele injusta agressão, atual ou iminente, a direito seu ou de outrem."

332 "Art. $1.210-[\ldots] \S 1^{\circ}-$ O possuidor turbado, ou esbulhado, poderá manter-se ou restituir-se por sua própria força, contanto que o faça logo; os atos de defesa, ou de desforço, não podem ir além do indispensável à manutenção, ou restituição da posse."

333 “Art. 1.283 - As raízes e os ramos de árvore, que ultrapassarem a extrema do prédio, poderão ser cortados, até o plano vertical divisório, pelo proprietário do terreno invadido."

334 “Art. 1.467 - São credores pignoratícios, independentemente de convenção: I - os hospedeiros, ou fornecedores de pousada ou alimento, sobre as bagagens, móveis, joias ou dinheiro que os seus consumidores ou fregueses tiverem consigo nas respectivas casas ou estabelecimentos, pelas despesas ou consumo que aí tiverem feito; II - o dono do prédio rústico ou urbano, sobre os bens móveis que o rendeiro ou inquilino tiver guarnecendo o mesmo prédio, pelos aluguéis ou rendas."

335 “Art. 1.469 - Em cada um dos casos do art. 1.467, o credor poderá tomar em garantia um ou mais objetos até o valor da dívida."

336 "Art. 1.470 - Os credores, compreendidos no art. 1.467, podem fazer o efetivo penhor, antes de recorrerem à autoridade judiciária, sempre que haja perigo de demora, dando aos devedores comprovante dos bens de que se apossarem."

337 "Art. 935 - Ao prejudicado também é lícito, se o caso for urgente, fazer o embargo extrajudicial, notificando verbalmente, perante 2 (duas) testemunhas, o proprietário, ou em sua falta, o construtor, para não continuar a obra. Parágrafo único - Dentro de 3 (três) dias requererá o nunciante a ratificação em juízo, sob pena de cessar o efeito do embargo."

${ }^{338}$ MAGALHÃES, José Carlos de, O Supremo Tribunal Federal e o direito internacional: uma análise crítica, cit., p. 41. 
Na medida que o exercício da jurisdição não é exclusivo do Estado, nem todo litígio necessariamente é composto pela intervenção estatal. Há exercício de jurisdição fora do Poder Judiciário.

Assim o é na mediação e na conciliação, meios autocompositivos de solução de litígios. Muito embora não haja decisão a ser imposta às partes, estas, ao acatarem a sugestão do mediador ou do conciliador, estão, ainda que de forma consensual, declarando o direito a reger a situação concreta que lhes envolve, pondo fim à lide.

E diferentemente não ocorre com a arbitragem e com o laudo arbitral, que é ato privado proferido por pessoa natural despida de qualquer autoridade pública, cuja fonte de autoridade "jurisdicional" que lhe é atribuída reside na vontade das partes.

Os indivíduos, as partes de um contrato que versa sobre direitos patrimoniais disponíveis, como detentores de jurisdição originária outorgam, delegam aos árbitros esse poder para, em seu nome e não em nome do Estado, declararem o direito controvertido sobre aquela relação jurídica de natureza privada. A jurisdição dos árbitros, ainda que também não originária, é privada, não estatal.

O contrário se dá com a jurisdição do juiz togado, também delegada, mas que provém da Constituição Federal e, assim, da comunidade nacional organizada. Suas decisões serão sempre atos de autoridade pública, atos estatais, atos oficiais. O árbitro, ao emitir o laudo, não atua como delegado do Estado, como o faz o juiz togado, mas das partes do contrato.

O laudo arbitral não provém de uma autoridade pública, não decorre de uma prestação jurisdicional de um Estado soberano, não é providência jurisdicional decorrente do exercício do poder jurisdicional delegado pela Constituição, o que por si só desautoriza a exigência de seu reconhecimento por país diverso daquele em cujo território foi proferido. É fruto de uma decisão tomada por árbitros escolhidos consensualmente pelas partes envolvidas para dirimir um litígio que envolva direitos patrimoniais disponíveis ${ }^{339}$. E, portanto, não há confusão que se possa fazer quanto aos efeitos do laudo arbitral e quanto aos efeitos da sentença judicial, a ponto de equipará-los.

\footnotetext{
339 HUCK, Hermes Marcelo, Sentença estrangeira e lex mercatoria: horizontes e fronteiras do comércio internacional, cit., p. 68.
} 
E a isso não parece ter notado o legislador, que conferiu ao laudo proferido fora do território nacional a qualidade de estrangeiro e, em equivocada coerência com o que fez com o laudo nacional, equiparando-o a uma sentença judicial no plano interno e incluindo-o entre os títulos executivos judiciais, conferiu-lhe o status de sentença estrangeira, condicionando, no artigo 35 da Lei n. 9.307/96, tal qual se dá com as sentenças estatais estrangeiras condenatórias que se pretenda sejam executadas em território nacional, o seu reconhecimento, simplesmente pelo fato de ter sido confeccionado fora do território nacional, à sua prévia homologação pelo Superior Tribunal de Justiça.

Serpa Lopes ${ }^{340}$, como já citado no capítulo anterior, tratou com clareza da sentença estrangeira. $\mathrm{O}$ que entende por sentença, do ponto de vista da origem da jurisdição, não merece reparos. Afirma que só pode ser conceituada como sentença a decisão que decorrer de uma atividade jurisdicional de órgãos realmente portadores de autoridade judiciária conferida pelo Estado. E, mais especificamente, com relação à sentença estrangeira, pondera: "Desde que o órgão judicante não recebe a sua jurisdição da mesma soberania, desde que a sentença é proferida por um juiz ou tribunal ligado a um Estado estrangeiro, estrangeira é esta sentença. É a decisão emanada de uma soberania estrangeira."

Conclui com perfeição: "Cumpre, assim, para a existência de uma sentença estrangeira, que ela decorra de uma atividade jurisdicional, de órgãos realmente portadores de autoridade judiciária conferida pelo Estado estrangeiro." ${ }^{341}$

Oscar Tenório ${ }^{342}$, comungando da mesma concepção sobre sentença, ensina que "sentença é expressão da soberania nacional".

O laudo, diferentemente, sempre foi ato privado, proferido por pessoa ou pessoas naturais, despidas de qualquer autoridade pública, destinados a dirimir controvérsias sobre relação contratual de natureza patrimonial. Não há intervenção de qualquer autoridade pública estrangeira que justifique sua prévia aceitação pelo órgão judiciário brasileiro. ${ }^{343}$

\footnotetext{
${ }^{340}$ SERPA LOPES, Miguel Maria de, Comentários à Lei de Introdução ao Código Civil, cit., v. 3, p. 207.

${ }^{341}$ Ibidem, p. 207.

342 TENÓRIO, Oscar Accioly. Direito internacional privado. 7. ed. Rio de Janeiro: Livraria Freitas Bastos, 1963. v. 2, p. 382.

${ }^{343}$ MAGALHÃES, José Carlos de, Reconhecimento e execução de laudos arbitrais estrangeiros, cit., p. 118.
} 
A Corte de Justiça das Comunidades Europeias, no caso Nordsee de 23.03.1982, havia decidido não possuir competência para decidir sobre atividades de tribunais arbitrais, na medida que eles detinham caráter privado. José Carlos de Magalhães ${ }^{344}$ explica que segundo essa decisão, apesar da similitude da arbitragem com o processo judicial, essa característica não se mostrava "suficiente para conferir ao árbitro a estatura de uma jurisdição estatal, tratando-se sempre de jurisdição privada e, portanto, despida de autoridade pública”.

Hildebrando Accioly ${ }^{345}$, no já citado parecer datado de 20 de junho de 1958, em que respondia a consultas sobre a ratificação ou não da convenção que viria a ser a Convenção de Nova Iorque, comungando do mesmo entendimento, deixava clara a sua posição sobre a natureza privada do laudo arbitral e a não equiparação (automática) a uma sentença judicial, revelando, com extrema clareza, a natureza do laudo arbitral decorrente da origem da jurisdição dos árbitros, ao dizer que “o julgamento arbitral, em matéria privada, não constitui manifestação de autoridade judiciária, que possa ser homologada pelo Supremo Tribunal Federal".

Em outra manifestação sobre o mesmo tema, em parecer datado de 4 de agosto de 1959, assim se manifestava a respeito de sua concepção de sentença estrangeira:

“10. Resta, porém, a questão da homologação, exigida pelo citado art. 15 da
LICC, artigo segundo o qual - lembro mais uma vez - só serão executadas
no Brasil as sentenças proferidas 'por juiz competente' e homologadas pelo
STF - entendendo-se como tais, conforme ensinam os mestres, as decisões
emanadas de autoridade judiciária, ou melhor, como se deduz do comentário
de Oscar Tenório (Lei de Introdução ao Código Civil brasileiro, p. 286),
revestidas de autoridade própria por 'um órgão do Estado'; ou ainda como
diz Serpa Lopes, mais de uma vez por mim citado, decorrentes de 'uma
atividade jurisdicional de órgãos realmente portadores de autoridade
judiciária conferida pelo Estado estrangeiro'.,346

Pontes de Miranda ${ }^{347}$, ao tratar da homologação do laudo arbitral estrangeiro, já notava que eram coisas distintas, afirmando que a eficácia que detém o laudo arbitral não é de maneira alguma a que possui a sentença estatal. Ponderava que "a sentença estrangeira, antes

\footnotetext{
${ }^{344}$ MAGALHÃES, José Carlos de, Reconhecimento e execução de laudos arbitrais estrangeiros, cit., p. 118, nota n. 2 .

${ }^{345}$ ACCIOLY, Hildebrando, Convenção sobre arbitragem comercial internacional, cit., p. 245. Nos outros três pareceres que estão reproduzidos nesse artigo, também se extrai o mesmo entendimento (Ibidem, p. 239-244 e 246-247).

${ }^{346}$ Ibidem, p. 247.

${ }^{347}$ PONTES DE MIRANDA, Francisco Cavalcanti, Tratado de direito privado, cit., v. 26, § 3.195, p. 385.
} 
da homologação, é dotada de eficácia sentencial, estatal; a decisão arbitral não". Nítida, portanto, a distinção entre laudo e sentença estatal, esta última detentora de eficácia sentencial, sendo, inequivocamente, título executivo judicial, ao contrário do primeiro, que não constitui manifestação de autoridade judiciária e, portanto, é título executivo extrajudicial.

Reproduzimos uma vez afirmação de Haroldo Valladão ${ }^{348}$ que, com exatidão, esclarece que laudos não homologados são considerados contratos:

\begin{abstract}
"Destarte os laudos arbitrais originados do estrangeiro e ali não judicialmente homologados são considerados contratos, equivalendo mesmo a uma transação, e se válidos segundo o DIP [...] ou seja segundo as nossas regras de conflitos produzirão os efeitos processuais de qualquer contrato no Brasil"
\end{abstract}

Machado Villela ${ }^{349}$ entendia que na medida que a arbitragem decorria da vontade das partes, que conferiam ao árbitro poder de julgar, a consequência lógica seria que seus atos jurídicos teriam caráter privado, assim como um contrato. Não se poderia, segundo o autor, através da vontade das partes, dar origem a um órgão que detivesse poder público, para que o laudo possuísse os efeitos de sentença estatal.

Muito embora tenham sido essas opiniões emitidas antes da edição da Lei de Arbitragem, não nos parece tenha sido ela que atribuiu jurisdicionalidade ao mecanismo privado de solução de controvérsias de que cuida a lei, e que claramente estabelece que a jurisdição dos árbitros provém de uma convenção privada, ao contrário da jurisdição do juiz togado, que advém da Constituição, e assim, da comunidade nacional.

O fato de ter havido o exercício de atividade jurisdicional não é fator preponderante para determinar a natureza do laudo arbitral, pois ela não é originária do Estado. Se o fosse, tudo que exercesse jurisdição teria resultados equiparáveis aos atos estatais.

A homologação de sentença judicial estrangeira se justifica por se tratar de ato oficial decorrente do exercício da jurisdição, enquanto função de Estado, que se pretenda seja

\footnotetext{
${ }^{348}$ VALLADÃO, Haroldo, Direito internacional privado, cit., v. 3, p. 217.

${ }^{349}$ VILLELA, Álvaro da Costa Machado. O direito internacional privado no Código Civil brasileiro. Coimbra: Imprensa da Universidade de Coimbra, 1921. p. 512.
} 
executada e cumprida em território subordinado à jurisdição de outro Estado, e não simplesmente pelo fato de ter havido atividade que culmina na declaração de um direito. Justifica-se nas hipóteses em que uma soberania esteja "a serviço" de outra. Assim, o ato oficial estrangeiro, seja uma sentença estatal, um decreto de divórcio do rei da Dinamarca, ou mesmo um registro de divórcio realizado perante o prefeito do Japão ${ }^{350}$, somente será executado e cumprido no território brasileiro se a autoridade pública brasileira (STJ), em observância aos requisitos que a lei brasileira fixar, o homologar, o admitir. ${ }^{351}$

A conduta do legislador parece revelar não ter havido essa clareza no momento de editar a norma, pois sua conduta demonstra uma concepção de jurisdição como sendo originária e exclusiva do Estado, a ponto de uma vez presente, impingir oficialidade ao ato, como se o fato do árbitro exercer atividade jurisdicional emprestasse ao laudo o atributo da oficialidade, equiparando-o a uma sentença estatal.

Reflete a mentalidade, ou quando pouco resquício dela, prevalecente no início da primeira metade do século XX, período em que a Convenção de Nova Iorque foi concebida, de que somente o Estado é que teria aptidão para solucionar controvérsias havidas entre particulares, ainda que exclusivamente de caráter privado.

Foi essa a mentalidade que norteou o tratamento conferido ao laudo arbitral estrangeiro, impondo sua prévia homologação, para que possa, em território nacional, ser executado.

$\mathrm{Na}$ realidade, diferença quanto à natureza não há entre um contrato celebrado no exterior e um laudo arbitral confeccionado fora do território nacional por árbitro que resolva a controvérsia decorrente desse mesmo contrato. Ambos possuem natureza privada. Mostra-se, como bem pondera José Carlos de Magalhães ${ }^{352}$, realmente “difícil de explicar a diversidade de tratamento, em função do local onde o laudo foi produzido, considerando-se que em ambos os casos trata-se de ato de natureza privada".

\footnotetext{
${ }^{350}$ Já dissemos no capítulo anterior que reputamos coerente com a natureza da sentença estrangeira, com o sistema de delibação e com a redação do parágrafo único do artigo 15 da Lei de Introdução às Normas do Direito Brasileiro, que apenas as sentenças judiciais estrangeiras condenatórias devam ser submetidas a homologação, sendo que nesse conceito não se enquadram evidentemente decretos de divórcio.

${ }^{351}$ MAGALHÃES, José Carlos de, Reconhecimento e execução de laudos arbitrais estrangeiros, cit., p. 118-119.

${ }^{352}$ Ibidem, p. 121.
} 
Isto ocorre porque os contratos celebrados no exterior, para serem cumpridos e executados no Brasil, não necessitam de qualquer chancela oficial do país em foi celebrado, para que seu cumprimento ou execução pela parte aqui domiciliada seja autorizado. Não se cogita de submetê-lo à previa apreciação do Poder Judiciário. Na eventualidade de demandas judiciais sobre tais contratos, o magistrado verificará o disposto no artigo 17 da Lei de Introdução às Normas do Direito Brasileiro, ou seja, se não contrariam os bons costumes, a ordem pública brasileira e a soberania nacional, como também o faria com qualquer outro contrato celebrado no Brasil. ${ }^{353}$

O mesmo deveria ocorrer com o laudo arbitral estrangeiro, que é ato privado decorrente da vontade das partes e tem a mesma natureza do contrato internacional firmado fora do país e que aqui deva ser cumprido.

O nobre objetivo almejado pelo legislador de que o não cumprimento voluntário do laudo arbitral ensejasse sua execução compulsória não necessitava equipará-lo ao que não é. Também os títulos executivos extrajudiciais autorizavam, e ainda autorizam, a execução compulsória à época da edição da Lei n. 9.307/96, segundo o artigo 585, inciso VII, do Código de Processo, que previa como título executivo extrajudicial "todos os demais títulos, a que, por disposição expressa, a lei atribuir força executiva".

Como no artigo 31 a Lei n. 9.307/96 expressamente declarava que o laudo arbitral constituía título executivo, a sua execução como título executivo extrajudicial, por ser essa a sua natureza, estava autorizada pelo artigo 585, inciso VII, do Código de Processo Civil, vigente à época. Dispensaria então a inútil homologação pelo Supremo Tribunal Federal, hoje, competente, por força da Emenda Constitucional n. 45/2004, o Superior Tribunal de Justiça. Por essas razões, José Carlos de Magalhães ${ }^{354}$ bem observa que "a alteração introduzida no art. 584, III, do CPC, feita pelo artigo 41 da Lei, incluindo-o dentre os títulos executivos judiciais, foi tecnicamente incorreta e desnecessária para os efeitos pretendidos”.

Atualmente o artigo que autorizaria a execução extrajudicial do laudo arbitral é o mesmo artigo 585, porém, no seu inciso VIII, que possui a mesma redação do inciso VII de outrora.

\footnotetext{
${ }^{353}$ MAGALHÃES, José Carlos de, Reconhecimento e execução de laudos arbitrais estrangeiros, cit., p. 118.

${ }^{354}$ Ibidem, mesma página.
} 
Concordamos com José Carlos de Magalhães que a conduta do legislador foi desnecessária e tecnicamente errada nesse ponto. A equiparação a sentença e consequentemente a chancela do Judiciário dada ao laudo arbitral estrangeiro retira da arbitragem a sua condição de decisão não judiciária. Tal equiparação e a necessidade de prévia homologação do laudo arbitral estrangeiro transfiguram a natureza do laudo arbitral.

Justifica-se $^{355}$ que tal equiparação à sentença judicial visava prestigiar o laudo arbitral, preservando-o, ao lhe conferir maior efetividade, pois ao atribuir-lhe o status de título executivo judicial, estar-se-ia restringindo as matérias de defesa nos embargos do devedor, quando do processo de execução.

É bem verdade que as hipóteses que autorizavam a interposição de embargos do devedor contra título executivo judicial constituíam um rol taxativo previsto no artigo 741 do Código de Processo Civil (atualmente a matéria encontra-se sob a rubrica do art. 475-L, que também traz um rol taxativo, embora não mais se fale em embargos à execução, mas sim em impugnação ao cumprimento de sentença) e, por outro lado, as matérias passíveis de serem arguidas em embargos do devedor contra título executivo extrajudicial estavam dispostas nos artigo 745 do Código de Processo Civil, que dispunha que, além das matérias previstas no artigo 741, poderia o devedor arguir qualquer outra matéria lícita de se arguir como defesa em processo de conhecimento. Atualmente as matérias passíveis de defesa encontram-se dispostas no mesmo artigo, no entanto com redação diversa, embora com a mesma ressalva no inciso VI de que poderá o devedor arguir qualquer matéria lícita de se deduzir como defesa em processo de conhecimento.

Contudo, se o que se pretendeu foi dar força ao laudo arbitral, diminuindo as matérias de defesa passíveis de alegação em embargos do devedor à execução, mais coerente com a técnica e com a natureza do laudo arbitral seria enquadrá-lo como título executivo extrajudicial, como tinha feito o artigo 31 da Lei n. 9.307/96, sem, evidentemente, equipará-lo em efeitos à sentença judicial, e também sem a alteração introduzida pelo artigo 41 da Lei n. 9.307/96 no artigo 584, III, do Código de Processo Civil. Para obter o efeito pretendido, deveria apenas ter limitado, à época, as matérias passíveis de arguição em embargos à execução (extrajudicial) de laudo arbitral, às hipóteses previstas nos artigos 38 e 39 da Lei,

355 DOLINGER, Jacob; TIBURCIO, Carmen, Direito internacional privado (parte especial): arbitragem comercial internacional, cit., p. 36. 
somadas às do artigo 741, então vigente, excluindo a aplicação, especificamente para a execução de laudo arbitral, da regra que permite ao devedor arguir qualquer matéria lícita de ser deduzida como defesa em processo de conhecimento.

Outra possibilidade seria incluí-las diretamente no Código de Processo Civil, por meio de um parágrafo inserido no artigo que trata das matérias passíveis de serem arguidas em embargos à execução contra execução de título executivo extrajudicial, ou de um parágrafo incluído no referido artigo, restringindo as matérias de defesa passíveis de arguição nos embargos contra a execução de laudo arbitral às hipóteses previstas no artigo 741, com remissão aos artigos 38 e 39 da Lei n. 9.307/96, ocasião em que o juiz da execução faria uma delibação incidental sobre as hipóteses de indeferimento constantes do artigo 39 da Lei e determinaria o prosseguimento da execução, para que o executado apresentasse embargos limitados às matérias elencadas nos artigos 741 do Código de Processo Civil e 38 da Lei n. 9.307/96. Ter-se-ia, assim, eliminado a necessidade de homologação prévia pelo Superior Tribunal de Justiça, com o que se privilegiaria ainda mais o instituto, na medida que não lhe retiraria a eficácia de estar apto a instaurar diretamente a execução, sem a dependência de um prévio processo judicial perante aquela corte.

Encontra-se em tramitação no Congresso Nacional o projeto de novo Código Processo Civil (PSL n. 166/2010) e nos parece uma boa hora para alterar a sistemática e eliminar a necessidade de homologação do laudo arbitral estrangeiro pelo Superior Tribunal de Justiça, como exposto acima. No entanto, tal como posta a sua redação original, não parece seja essa a pretensão. O legislador processual civil teima em insistir na concepção de que o exercício da jurisdição é originária do Estado. No seu entender, uma vez presente a atividade de declarar o direito, atividade jurisdicional portanto, que como demonstrado é delegada ao Estado e não originária e muito menos exclusiva dele, emprestaria aos atos decisórios não judiciais o atributo da oficialidade e efeitos próprio de atos de Estado, equiparando-o à sentença judicial e exigindo a sua homologação.

É o que se lê do artigo 879, parágrafo $1^{\circ}$, inserido no Capítulo $\mathrm{V}$, intitulado "Da homologação de sentença estrangeira ou de sentença arbitral", Título I ,"Do processo nos tribunais", Livro IV "Dos processos nos tribunais e dos meios de impugnação das decisões judiciais". 
A redação desse artigo é a seguinte:

“Art. 879 - As decisões estrangeiras somente terão eficácia no Brasil após homologadas.

$\S 1^{\circ}$ - São passíveis de homologação todas as decisões, interlocutórias ou finais, bem como as não judiciais que, pela lei brasileira teriam natureza jurisdicional." (grifamos). ${ }^{356}$

Como o título do Capítulo V, no qual está inserido o artigo, é "Homologação de sentença estrangeira ou sentença arbitral", o artigo se aplica aos laudos arbitrais estrangeiros, assim entendidos os que foram confeccionados fora do território nacional. E disso extraímos que embora não judicial a decisão arbitral, pelo fato de, no entendimento do legislador ter natureza jurisdicional, posto que a Lei de Arbitragem a incluiu dentre os títulos executivos judiciais, se manterá a necessidade de homologação.

Curioso notar também que o referido parágrafo $1^{\circ}$ é claro em dispor que também devem ser homologadas as decisões não judiciais que pela lei brasileira tenham natureza jurisdicional. De duas, uma. Ou a lei passa a especificar o que tem natureza jurisdicional, ou não se homologa mais o que não estiver incluído no rol de títulos executivos judiciais, como, por exemplo, decretos de divórcio emitidos por autoridades políticas e administrativas e mesmo decisões de tribunais religiosos.

Notamos ainda que o artigo $881^{357}$ trata dos requisitos reputados como indispensáveis à homologação da decisão, e como o título do capítulo especifica tratar de homologação de "sentença arbitral”, não seria equivocado sustentar que o referido artigo revogaria, fosse assim aprovado o projeto, os artigos 38 e 39 da Lei de Arbitragem. Vemos também que no Capítulo V ressalva alguma há quanto aos requisitos para a homologação do laudo arbitral estrangeiro, ou qualquer remissão ou menção à Lei de Arbitragem.

São apenas algumas primeiras impressões.

\footnotetext{
${ }^{356}$ Semelhante redação se encontra no artigo $4^{\circ}$, parágrafo $1^{\circ}$, da Resolução n. 9 , de 2005 , do Superior Tribunal de Justiça: "Serão homologados os provimentos não judiciais que, pela lei brasileira, teriam natureza de sentença."

357 “Art. 881 - Constituem requisitos indispensáveis à homologação da decisão: I - ser proferida por autoridade competente; II - ser precedida de citação regular, ainda que verificada a revelia; III - ser eficaz no país em que foi proferida; IV - estar autenticada pelo cônsul brasileiro e acompanhada de tradução oficial; V - não haver manifesta ofensa à ordem pública. Parágrafo único - As medidas de urgência, ainda que proferidas sem a audiência do réu, poderão ser homologadas, desde que garantido o contraditório em momento posterior."
} 


\subsubsection{A inconstitucionalidade do artigo 35}

O equívoco quanto à natureza do laudo arbitral fez com que o legislador incidisse em outro erro, ao determinar no artigo 35 da de Arbitragem que "para ser reconhecida ou executada no Brasil, a sentença arbitral estrangeira está sujeita, unicamente, à homologação pelo Supremo Tribunal Federal”.

Ao Supremo Tribunal Federal compete julgar originariamente as hipóteses previstas no inciso I, e em grau recursal as hipóteses previstas nos incisos II e III do artigo 102, sendo que na alínea "h" do inciso I estava prevista como competência - originária - do Supremo "a homologação de sentenças estrangeiras e a concessão do exequatur às cartas rogatórias, que podem ser conferidas pelo regimento interno a seu presidente". Hoje essa competência foi transferida ao Superior Tribunal de Justiça (art. 105, inc. I, “i” da CF), por força da Emenda Constitucional n. 45/2004.

Ao modo de atribuir competência aos tribunais, diferente tratamento dispensou a Constituição Federal. Ao tratar da competência do Tribunal Superior do Trabalho, estabeleceu que a lei disporia acerca de sua competência. Assim o fez no artigo 112, parágrafo $3^{\circ}$ : "A lei disporá sobre a competência do Tribunal Superior do Trabalho". No mesmo sentido, com relação à Justiça Eleitoral, o artigo 121 dispõe que "lei complementar disporá sobre a organização e competência dos Tribunais, dos juízes de direito e das Juntas Eleitorais". Ainda seguindo o critério de que a lei regulará a competência dos tribunais, também o fez com relação aos tribunais e juízes militares, dispondo no artigo 124 que "a lei disporá sobre a organização, o funcionamento e a competência da Justiça Militar”.

Por outro lado, a Constituição Federal em suas normas fixou a competência do Supremo Tribunal Federal (art. 102), do Superior Tribunal de Justiça (art. 105) e dos Tribunais Regionais Federais e juízes federais. Para esses últimos casos, por estarem as competências especificadas no texto constitucional, nos parece que qualquer alteração que se pretenda implica em alterar os dispositivos constitucionais em questão. Para tanto, a nosso ver, deve ser observada a tramitação estipulada no artigo $60^{358}$ da Constituição Federal.

\footnotetext{
358 “Art. 60 - A Constituição poderá ser emendada mediante proposta: I - de um terço, no mínimo, dos membros da Câmara dos Deputados ou do Senado Federal; II - do Presidente da República; III - de mais da metade das Assembleias Legislativas das Unidades da Federação, manifestando-se, cada uma delas, pela maioria relativa de seus membros. [...] $\S 2^{\circ}$ - A proposta será discutida e votada em cada Casa do Congresso Nacional, em dois turnos, considerando-se aprovada se obtiver, em ambos, três quintos dos votos dos respectivos membros."
} 
José Carlos de Magalhães ${ }^{359}$, com razão, pondera:

"O simples fato de a Constituição deixar claro que, em determinados casos, a competência será fixada por lei, deixando de prever norma similar para o Supremo Tribunal Federal, Superior Tribunal de Justiça, Tribunais Regionais Federais e para os Juízes Federais, revela que o Constituinte quis estabelecer competência fixa e determinada para aquelas Cortes, somente modificável por meio de emenda constitucional."

Portanto, qualquer alteração na competência tanto do Supremo Tribunal Federal quanto do Superior Tribunal de Justiça devem ser precedidas de emendas constitucionais que observem o procedimento estabelecido no artigo 60 da Constituição Federal. Assim se deu com a Emenda Constitucional n. 45/2004, em que houve a possibilidade de se incluir dentre as competências do Superior Tribunal de Justiça a de homologar laudos arbitrais estrangeiros, com o que estaria sanado o problema. Não o fizeram.

A norma constitucional que dizia que o Supremo Tribunal Federal era, e agora o Superior Tribunal de Justiça é competente para homologar sentenças estrangeiras, mostra-se precisa, sem margem a polissemia. Trata-se de sentença judicial, oriunda de autoridade judiciária no exercício de poder jurisdicional enquanto função estatal ${ }^{360}$. Como mais de uma vez citado, Serpa Lopes ${ }^{361}$, e bem assim Oscar Tenório ${ }^{362}$ e Hildebrando Accioly ${ }^{363}$, entendem que para a existência de uma sentença estrangeira, ela deve decorrer de uma autoridade jurisdicional de órgãos portadores de autoridade judiciária conferida por Estado soberano estrangeiro. E laudos arbitrais não se enquadram automaticamente nesse conceito.

Diante disso, nos parece inequívoco que o artigo 35 atribuiu à Corte Suprema competência constitucional originária, e agora ao Superior Tribunal de Justiça, não prevista no rol constante do artigo 102, inciso I, da Constituição Federal (atual art. 105, inc. I, “i”), sem que se tenha observado o rito estabelecido para as emendas constitucionais, de modo que o reputamos inconstitucional. ${ }^{364}$

\footnotetext{
${ }^{359}$ MAGALHÃES, José Carlos de, Reconhecimento e execução de laudos arbitrais estrangeiros, cit., p. 120-121.

${ }^{360}$ Ibidem, p. 121.

${ }^{361}$ SERPA LOPES, Miguel Maria de, Comentários à Lei de Introdução ao Código Civil, cit., v. 3, p. 207.

${ }^{362}$ TENÓRIO, Oscar Accioly, Direito internacional privado, cit., v. 2, p. 382.

${ }^{363}$ ACCIOLY, Hildebrando, Convenção sobre arbitragem comercial internacional, cit., p. 247.

${ }^{364}$ CÂMARA, Alexandre Freitas. Arbitragem: Lei n. 9.307/96. 4. ed. Rio de Janeiro: Lumen Juris, 2005. p. 157158; MAGALHÃES, José Carlos de, op. cit., p. 121.
} 


\subsection{A ratificação da Convenção de Nova Iorque e seus efeitos sobre a homologação do laudo arbitral estrangeiro}

Prevalecia no mundo na primeira metade do século XX a mentalidade do monopólio do Estado para a solução de todo e qualquer conflito de interesses havido entre os indivíduos e mesmo entre empresas, estes últimos relacionados, na maioria das vezes, a controvérsias privadas, sobretudo de caráter comercial e internacional, sendo, ainda, que os conflitos advindos de investimentos de países estrangeiros nesse período decorriam no mais das vezes da aplicação de leis discriminatórias contra o estrangeiro ou sobre tratamento de capitais provenientes do exterior. ${ }^{365}$

Tal fato passou a preocupar as empresas e os investidores estrangeiros, bem como os operadores do comércio internacional, que cada vez mais passavam a depender do Estado. Consequência disso foi que o contrato passou a ter primordial importância no relacionamento entre empresas, com a inserção de cláusulas visando à proteção dos investidores estrangeiros, dentre as quais sobressaíam as que estipulavam o direito a ser aplicável e a arbitragem, com claro intuito de que eventuais controvérsias dele decorrentes fossem resolvidas sem a indesejada interferência do Estado, fosse legislativa, fosse judiciária. ${ }^{366}$

No entanto, em numerosos países havia o entendimento de que não bastava a cláusula arbitral para instituir o juízo arbitral. Era necessária a assinatura de outro contrato, o compromisso arbitral. ${ }^{367}$

Buscava-se então a formação de tratados que visassem a suprir essa deficiência, que criava empecilhos, de certa forma, ao livre desenvolvimento do comércio internacional. Assim se deu com o Protocolo de Genebra de 1923 sobre Cláusulas Arbitrais, cujo objetivo foi o de conferir compulsoriedade à cláusula arbitral, que foi ratificado pelo Brasil e posto em vigor pelo Decreto n. 21.187, de 22 de março de 1932.

\footnotetext{
${ }^{365}$ MAGALHÃES, José Carlos de. A tardia ratificação da Convenção de Nova Iorque sobre a arbitragem: um retrocesso desnecessário e inconveniente. Revista de Arbitragem e Mediação, São Paulo, Revista dos Tribunais, ano 5, n. 18, p. 24-27, 2008.

${ }^{366}$ Ibidem, p. 24-27.

${ }^{367}$ Ibidem, p. 28.
} 
Estabelecia-se novamente o princípio de que os próprios comerciantes poderiam resolver seus litígios, sem qualquer intervenção governamental, princípio propugnado pela Revolução Francesa. No entanto, essa opção pela forma privada de solução de litígios ainda causava receios na comunidade internacional. Pairava ainda a mentalidade do monopólio estatal para solucionar todo e qualquer conflito de interesses. ${ }^{368}$

Faltava uma convenção que buscasse dar efetividade às decisões arbitrais proferidas no exterior, o que foi feito pela Convenção de Genebra de $1927^{369}$, que tratava especificamente da execução de laudos arbitrais estrangeiros. Alcançava-se assim o objetivo almejado: o contrato com a cláusula arbitral possuía efetividade para impor a constituição do juízo arbitral e a efetividade do laudo arbitral, com seu reconhecimento para fins de execução. $^{370}$

José Carlos de Magalhães ${ }^{371}$ afirma que esse processo evolutivo foi selado com a Convenção de Nova Iorque de 1958, que dispunha sobre as mesmas matérias das convenções acima comentadas, assegurando a eficácia da convenção arbitral, conceito em que se compreende tanto a cláusula compromissória quanto o compromisso arbitral, e também o reconhecimento e a validade dos laudos arbitrais confeccionados em territórios de outros países, e que em seu artigo VII, 2, revogava expressamente o Protocolo de Genebra de 1923 e a Convenção de Genebra de 1927, declarando que "cessarão seus efeitos dentre os Estados Contratantes, nos seus limites e para os de que venham a se vincular a esta Convenção".

Sua adoção, à época, pelos Estados representava segurança jurídica para o contratante estrangeiro, quanto ao fato de que surgida eventual controvérsia oriunda do contrato, a cláusula arbitral teria eficácia e a controvérsia seria resolvida com o afastamento da competência dos tribunais locais para a apreciação dessa controvérsia, e que a decisão proferida também teria efetividade, com seu pleno reconhecimento.

No pano internacional, aos poucos foi sendo reconhecida como padrão para o tema da execução de laudos arbitrais estrangeiros e gradativamente foi adotada por inúmeros países.

\footnotetext{
${ }^{368}$ MAGALHÃES, José Carlos de, A tardia ratificação da Convenção de Nova Iorque sobre a arbitragem: um retrocesso desnecessário e inconveniente, cit., p. 28.

${ }^{369}$ O Brasil não a ratificara.

${ }^{370}$ MAGALHÃES, José Carlos de, op. cit., p. 29.

${ }^{371}$ Ibidem, mesma página.
} 
Hoje é tida como um dos tratados internacionais mais utilizados e com maior número de adesões no mundo. ${ }^{372}$

A Convenção representou, então, um grande marco no processo de superação do monopólio do Estado e da participação da sociedade civil e do indivíduo no âmbito internacional. Tornou-se referência de segurança jurídica para os partícipes das relações comerciais internacionais domiciliados nos países dela signatários. E assim, vários países foram adequando suas legislações aos princípios nela insculpidos, com o objetivo de conferir eficácia à clausula arbitral e reconhecimento de laudos arbitrais produzidos no exterior. ${ }^{373}$

No entanto, não se livrara completamente dessa mentalidade, ao considerar a possibilidade de condicionar o reconhecimento de laudos arbitrais estrangeiros proferidos no exterior, o que era, de certa forma, compreensível à época. Mantinha a exigência de homologação dos laudos arbitrais produzidos no exterior, selando a intromissão indesejada e indevida do Estado no mecanismo tipicamente privado, extrajudicial de solução de controvérsias e voltadas ao comércio internacional. Tal fato revela que ainda havia resquício do monopólio do Estado para solucionar controvérsias comerciais. Se o laudo arbitral é ato privado proferido por pessoas que não exercem função pública, e que tampouco se revestem de qualquer autoridade estatal, não haveria se cogitar de sua homologação no país em que se pretenda executar.

O mundo passou por inúmeras transformações a partir da metade do século passado, o movimento político das Nações Unidas para a descolonização que culminou com o ingresso de muitos países da África e da Ásia na Assembleia Geral das Nações Unidas, o fortalecimento da sociedade civil perante o poder estatal em todo o planeta, com o aparecimento das empresas multinacionais e mesmo organizações não governamentais de abrangência mundial, a globalização da economia, o fim da guerra fria, o crescente desenvolvimento dos sistemas e das tecnologias da informação, que possibilitou um maior intercâmbio jurídico e cultural e uma maior agilidade nas transações comerciais. Todos

\footnotetext{
372 ARAUJO, Nadia de. A Convenção de Nova York sobre o reconhecimento e execução de laudos arbitrais estrangeiros: análise das razões contrárias a sua adoção nos anos 50 do século XX. Revista de Arbitragem e Mediação. São Paulo, Revista dos Tribunais, ano 5, n. 18, p. 48, 2008.

${ }^{373}$ MAGALHÃES, José Carlos de, A tardia ratificação da Convenção de Nova Iorque sobre a arbitragem: um retrocesso desnecessário e inconveniente, cit., p. 36.
} 
verificados após a confecção da Convenção. O mundo, então, era outro e a mentalidade que inspirara a edição da Convenção vinha sendo superada. ${ }^{374}$

O Brasil, no momento em que era necessário e oportuno, relutou e não ratificou a Convenção de Nova Iorque, apegando-se a ideia de que ao firmá-la limitaria sua soberania, pois vigorava entre nós a mentalidade do monopólio do Estado no exercício da jurisdição. ${ }^{375}$

Somente em 1996 editou sua lei sobre arbitragem, que foi "fortemente inspirada pelos cânones da Convenção de Nova York"376, a qual havia se baseado em uma concepção de mundo já superada, e ainda na Lei Uniforme aprovada pela Uncitral de 1985, regulando inteiramente as matérias que contém a Convenção. Como já se disse anrteriormente, é communis opinio da doutrina que a edição da Lei de Arbitragem impulsionou a utilização do mecanismo privado de solução de litígios no Brasil.

A edição dessa Lei tornava então desnecessária a ratificação da Convenção, por já tratar, inclusive com melhor técnica, de todos os temas nela versados. No entanto, o Congresso Nacional aprovou o Decreto n. 4.311, de 23 de julho de 2002, e colocou em vigor entre nós a Convenção de Nova Iorque de 1958.

O entendimento do Supremo Tribunal Federal ${ }^{377}$, baseado no princípio lex posteriori derogat priori, é o de que o tratado internacional ratificado produz o efeito de derrogar as normas do ordenamento jurídico interno que com ele sejam conflitantes e, como dito acima, a Lei já havia tratado dos temas versados na Convenção, que se encontra em vigor em toda a sua amplitude no território nacional.

Desse modo, e na medida que a Convenção é dirigida à aplicação pelo Poder Judiciário, mister se faz analisar as consequências, relacionadas ao objeto do presente estudo, dessa tardia ratificação da Lei n. 9.307/96.

\footnotetext{
${ }^{374}$ MAGALHÃES, José Carlos de, A tardia ratificação da Convenção de Nova Iorque sobre a arbitragem: um retrocesso desnecessário e inconveniente, cit., p. 30-34.

${ }^{375}$ Ibidem, p. 34.

${ }^{376}$ ARAUJO, Nadia de, A Convenção de Nova York sobre o reconhecimento e execução de laudos arbitrais estrangeiros: análise das razões contrárias a sua adoção nos anos 50 do século XX, cit., p. 48.

${ }^{377}$ Acórdão n. 8.004, publicado na RTJ 83/809.
} 


\subsubsection{O tratamento conferido ao laudo arbitral estrangeiro}

A Lei de Arbitragem, por meio de seus artigos 18 e 31, dispensa a chancela oficial ao laudo arbitral produzido em território nacional, prescindindo assim de sua homologação para que possa surtir seus desejáveis efeitos tão logo proferido, afastando, desse modo, a sempre indesejável intervenção estatal, exceto nos casos de nulidade por inobservância dos requisitos exigidos na lei.

Já o seu artigo 35 mantém a exigência de que os laudos confeccionados fora do território nacional sejam homologados pelo Superior Tribunal de Justiça, para que só então se revelem aptos a instaurar o processo de execução de título executivo judicial em face do renitente em cumprir a decisão arbitral.

Estipula o artigo III da Convenção ${ }^{378}$, por outro lado, que os Estados signatários não devem impor na disciplina legal do reconhecimento e execução de laudos arbitrais estrangeiros "condições substancialmente mais onerosas ou taxas ou cobranças mais altas" que as previstas para o reconhecimento ou execução dos laudos nacionais.

É, portanto, conflitante e incompatível com o estabelecido no artigo 35 da Lei de Arbitragem, pois a lei brasileira, como visto, não requer o reconhecimento dos laudos arbitrais produzidos no país, atribui-lhes efeitos independentemente de qualquer chancela oficial, tornando-os aptos a ensejar um procedimento de execução de título executivo judicial, ao passo que o laudo estrangeiro só adquire essa aptidão após homologado.

A nosso sentir, a disposição do artigo III da Convenção importaria em derrogação da sujeição dos laudos arbitrais estrangeiros ao juízo homologatório, expressa no artigo 35, por constituir uma condição mais onerosa que a prevista para que o laudo nacional produza efeitos.

\footnotetext{
378 “Art. III - Cada Estado signatário reconhecerá como obrigatórias e as executará em conformidade com as regras de procedimento do território na qual a sentença é invocada, de acordo com as condições estabelecidas nos artigos que se seguem."
} 
Por outro lado, Carlos Alberto Carmona ${ }^{379}$ e Selma M. Ferreira Lemes ${ }^{380}$ entendem em plena vigência o dispositivo que exige a homologação dos laudos arbitrais confeccionados fora do território nacional, por não vislumbrarem incompatibilidade entre os artigos 35 da Lei de Arbitragem e III da Convenção de Nova Iorque.

O Supremo Tribunal Federal homologava e agora o Superior Tribunal de Justiça continua a homologar laudos arbitrais produzidos no exterior, o que, segundo, e não sem razão, para José Carlos de Magalhães ${ }^{381}$ “indica a tendência tradicional do Judiciário brasileiro de ignorar as convenções internacionais conflitantes com a lei interna. Há na exigência flagrante descumprimento da Convenção, pois se dá tratamento diferenciado entre laudo arbitral produzido no território nacional e o no exterior".

Afirma ainda:

"Se, algum dia, o STJ se demorar na apreciação dessa Convenção e do efeito derrogatório na lei nacional, poderá deixar de apreciar os pedidos de homologação de laudos estrangeiros submetidos por advogados que não querem sofrer do risco de requererem a sua execução diretamente no juízo do domicílio do réu e terem a pretensão rejeitada em virtude da manutenção do entendimento daquela Corte." 382

Jacob Dolinger e Carmen Tiburcio ${ }^{383}$ esclarecem que "parcela considerável da doutrina nacional defende o entendimento" de que a norma prevista no artigo 105, I, "i" da Constituição Federal determina a obrigatoriedade da homologação de sentenças estrangeiras, e por se tratar de norma constitucional, estaria situada em um patamar superior ao dos tratados, os quais, por esse motivo, não teriam o condão de revogar a aludida norma constitucional. Ocorre que, como já defendido no capítulo anterior, a norma trata da competência do Superior Tribunal de Justiça de homologar as sentenças judiciais estrangeiras, e não laudos arbitrais confeccionados fora do território nacional, e que a lei

\footnotetext{
${ }^{379}$ CARMONA, Carlos Alberto, Arbitragem e processo: um comentário à Lei n. 9.307/96, cit., p. 355-356.

${ }^{380}$ LEMES, Selma M. Ferreira. Reconhecimento da sentença arbitral estrangeira no Brasil. Valor Econômico, de 08 ago. 2003, p. E-4.

${ }^{381}$ MAGALHÃES, José Carlos de, A tardia ratificação da Convenção de Nova Iorque sobre a arbitragem: um retrocesso desnecessário e inconveniente, cit., p. 40-41.

382 MAGALHÃES, José Carlos de, A tardia ratificação da Convenção de Nova Iorque sobre a arbitragem: um retrocesso desnecessário e inconveniente, cit., p. 40-41.

383 DOLINGER, Jacob; TIBURCIO, Carmen, Direito internacional privado (parte especial): arbitragem comercial internacional, cit., p. 45.
} 
infraconstitucional determinar que devam ser homologadas. Não a vemos sequer como um imperativo para a homologação de sentenças judiciais estrangeiras.

Outro ponto que poderia causar polêmica seria quanto à derrogação das hipóteses de rejeição do pedido de homologação enumeradas nos artigos 38 e 39 da Lei de Arbitragem, uma vez que a Convenção também estipula, em seu artigo V, um rol taxativo de hipóteses em que poderia ocorrer a denegação da homologação.

Ocorre que, da análise desses dispositivos, nota-se que nos incisos compreendidos nos artigos 38 e 39 da Lei foram elencados todos os mesmos casos em que seria possível a denegação da homologação previstos na Convenção. Não há, portanto, que se falar que a Convenção derrogou a Lei neste ponto, pois não há incompatibilidade entre as disposições.

\subsection{Processo de homologação. Hipóteses de indeferimento}

Os mesmos comentários aventados no item 2.6 do capítulo anterior, relativos ao procedimento adotado para a homologação de sentenças judiciais, aplicam-se ao processamento da ação de homologação de laudo arbitral estrangeiro.

A Lei n. 9.307/96 estipula requisitos próprios e distintos do sistema de homologação de sentenças judiciais estrangeiras, de modo que não são observados os previstos no artigo 15 da Lei de Introdução às Normas do Direito Brasileiro. Ora, tal fato é no mínimo curioso. Se a lei equipara em efeitos o laudo arbitral a sentença judicial, inclusive fazendo-o constar no rol de títulos executivos judiciais, e se também condiciona a execução do laudo arbitral estrangeiro à sua prévia homologação no Superior Tribunal de Justiça, assim como é para as sentenças estrangeiras condição para sua execução em território nacional, porque não se adotarem os mesmos requisitos previstos na Lei de Introdução? A resposta que se impõe só pode ser uma. Por se tratarem de coisas distintas, porque as origens do poder de decidir do árbitro e do juiz togado são diversas, e por esse motivo não poderiam ter sido equipadas. Nada obstante, passemos à breve análise das hipóteses em que o pedido de homologação pode ser rejeitado. 
O artigo $38^{384}$ limita as matérias passíveis de alegação pela parte contra quem se pretenda executar o laudo em território nacional. Nessas hipóteses, como observa Carmona ${ }^{385}$, “o sucesso da impugnação dependerá da demonstração, pelo réu, da ocorrência de algum daqueles casos". Em outras palavras, essas hipóteses devem ser alegadas e provadas pela parte contrária. São as mesmas situações descritas no artigo V, n. 1, da Convenção de Nova Iorque. $^{386}$

\subsubsection{As partes na convenção de arbitragem eram incapazes}

Este requisito está ligado à validade da convenção de arbitragem. Trata da capacidade dos contratantes, situação jurídica que permite a qualquer pessoa exercer seus direitos por si mesma. A sua ausência invalidará a convenção de arbitragem, acarretando invariavelmente a nulidade do laudo arbitral.

Poderia surgir aqui dúvida sobre qual lei rege a capacidade das partes.

\footnotetext{
384 “Art. 38 - Somente poderá ser negada a homologação para o reconhecimento ou execução de sentença arbitral estrangeira, quando o réu demonstrar que: I - as partes na convenção de arbitragem eram incapazes; II - a convenção de arbitragem não era válida segundo a lei à qual as partes se submeteram, ou, na falta de indicação, em virtude da lei do país onde a sentença arbitral foi proferida; III - não foi notificado da designação do árbitro ou do procedimento de arbitragem, ou tenha sido violado o princípio do contraditório, impossibilitando a ampla defesa; IV - a sentença arbitral foi proferida fora dos limites da convenção de arbitragem, e não foi possível separar a parte excedente daquela submetida à arbitragem; V - a instituição da arbitragem não está de acordo com o compromisso arbitral ou a cláusula compromissória; VI - a sentença arbitral não se tenha, ainda, tornado obrigatória para as partes, tenha sido anulada, ou, ainda, tenha sido suspensa por órgão judicial do país onde a sentença arbitral for prolatada."

385 CARMONA, Carlos Alberto, Arbitragem e processo: um comentário à Lei n. 9.307/96, cit., p. 367.

${ }^{386}$ Convenção de Nova Iorque: “Art. V. n. 1 [...] a) as partes do acordo a que se refere o artigo II estavam, em conformidade com a lei a elas aplicável, de algum modo incapacitadas, ou que tal acordo não é válido nos termos da lei à qual as partes o submeteram, ou, na ausência de indicação sobre a matéria, nos termos da lei do país onde a sentença foi proferida; b) a parte contra a qual a sentença é invocada não recebeu notificação apropriada acerca da designação do árbitro ou do processo de arbitragem, ou lhe foi impossível, por outras razões, apresentar seus argumentos; c) a sentença se refere a uma divergência que não está prevista ou que não se enquadra nos termos da cláusula de submissão à arbitragem, ou contém decisões acerca de matérias que transcendem o alcance da cláusula de submissão, contanto que, se as decisões sobre as matérias suscetíveis de arbitragem puderem ser separadas daquelas não suscetíveis, a parte da sentença que contém decisões sobre matérias suscetíveis de arbitragem possa se reconhecida e executada; ou d) a composição da autoridade arbitral ou o procedimento arbitral não se deu em conformidade com o acordado pelas partes, ou, na ausência de tal acordo, não se deu em conformidade com a lei do país em que a arbitragem ocorreu; ou e) a sentença ainda não se tornou obrigatória para as partes ou foi anulada ou suspensa por autoridade competente do país em que, ou conforme a lei do qual, a sentença tenha sido proferida."
} 
Diferentemente do que faria o magistrado brasileiro, que observaria o artigo $7^{\circ}$ da Lei de Introdução ${ }^{387}$ para a qualificação das partes, o árbitro, ao iniciar o julgamento, deverá recorrer à lei material escolhida pelas partes para aferir se elas eram ou não capazes quando firmaram a convenção arbitral. A lei escolhida pelas partes será então a aplicada para a qualificação dos litigantes.

A escolha pelas partes de um ordenamento jurídico estabelecendo o direito material a ser aplicado para dirimir a controvérsia vincula o árbitro, de modo que ele se reportará aos critérios da lei escolhida pelas partes para aferir a capacidade. Esse fato, além de privilegiar a autonomia da vontade, oferecerá ao tribunal do local onde se pretenda executar o laudo maior segurança para aferir os requisitos de validade da convenção de arbitragem. ${ }^{388}$

Poderá ocorrer de não terem as partes estabelecido a lei aplicável, ocasião na qual o árbitro identificará os elementos de conexão que reputar relevantes e decidirá com base na regra de conflito de leis a ser empregada no caso concreto. ${ }^{389}$

Caberá, por fim, ao Superior Tribunal de Justiça, tão somente verificar se pela lei material aplicada, as partes eram capazes. De modo algum poderá o Superior Tribunal de Justiça aferir se lei empregada pelo árbitro para a qualificação das partes foi ou não a mais adequada.

A Convenção de Nova Iorque elenca a mesma hipótese, no entanto com redação um pouco confusa ${ }^{390}$. A Lei Modelo da UNCITRAL é menos esclarecedora, pois limita-se, em seu artigo 36, 1, “a”, “i”, a estabelecer simplesmente que a incapacidade é hipótese em que pode ser denegada a homologação do laudo. Nada especifica acerca da lei aplicável na análise. $^{391}$

\footnotetext{
387 "Art. $7^{\circ}$ - A lei do país em que for domiciliada a pessoa determina as regras sobre o começo e o fim da personalidade, o nome, a capacidade e os direitos de família."

${ }^{388}$ CARMONA, Carlos Alberto, Arbitragem e processo: um comentário à Lei n. 9.307/96, cit., p. 369.

${ }^{389}$ Ibidem, p. 370.

390 Ibidem, mesma página.

391 Ibidem, mesma página.
} 


\subsubsection{A convenção de arbitragem não era válida segundo a lei à qual as partes se submeteram, ou, na falta de indicação, em virtude da lei do país onde a sentença arbitral foi proferida}

Trata-se de requisito relacionado tanto à forma quanto ao conteúdo da cláusula ou do compromisso arbitral. Verificada a nulidade, o laudo terá seu reconhecimento obstado.

Deve ser analisado, quanto à forma, se a lei escolhida pelas partes a ser aplicada pelos árbitros prevê forma específica para a confecção da convenção de arbitragem. É o que no Brasil ocorre, por exemplo, para a elaboração do compromisso arbitral, onde se exige escritura pública ou documento particular assinado por duas testemunhas. A ausência das formas previstas na lei, se provada, constitui fundamento para a negativa de homologação do laudo arbitral estrangeiro.

Com relação ao conteúdo, a lei escolhida como aplicável ao caso concreto pelas partes deve admitir a arbitralidade do objeto da controvérsia. Em outras palavras, a lei escolhida pelas partes deve admitir a solução da controvérsia por via da arbitragem. Caso não admita, será nulo o pacto que estipular a arbitragem como mecanismo alternativo de solução do litígio. Não é suficiente, de acordo com a Lei de Arbitragem, que a matéria objeto do pacto arbitral seja, segundo a legislação brasileira, arbitrável. ${ }^{392}$

Nada sendo estabelecido acerca da lei a ser aplicada pelo árbitro, mostra-se imperioso analisar se o pacto arbitral está em consonância como os critérios (de forma e conteúdo) estipulados pela lei do lugar em que será confeccionado o laudo arbitral, critério estabelecido como subsidiário pelo legislador nacional.

${ }^{392}$ CARMONA, Carlos Alberto, Arbitragem e processo: um comentário à Lei n. 9.307/96, cit., p. 371. 


\subsubsection{Não foi notificado da designação do árbitro ou do procedimento de arbitragem, ou tenha sido violado o princípio do contraditório, impossibilitando a ampla defesa}

Trata-se de hipótese relacionada à garantia do que se poderia denominar de devido processo arbitral, que impõe seja observado o direito ao contraditório e à ampla defesa.

A análise do dispositivo legal revela duas imbricadas situações em que pode ser denegada a homologação. Uma delas está relacionada ao prejuízo ao direito de defesa. Nessa análise deve-se verificar se foi oportunizada à parte efetiva possibilidade de explanar e fazer valer suas razões no decorrer do procedimento arbitral, ou seja, efetivo direito de defesa. E como pressuposto para o exercício desse direito temos a informação como de vital importância. Sem informação não há como se estabelecer um contraditório válido. Mister se impõe para que não esteja configurada a hipótese prevista no inciso III do artigo 38, que tenha havido para as partes igualitária possibilidade de participar do procedimento arbitral desde a sua instauração, até a decisão do árbitro.

Oportuno esclarecer que os prazos, as formas e o modo de se realizarem os atos procedimentais, objeto de análise pelo órgão competente para a homologação, serão os estipulados no pacto arbitral.

Quanto ao segundo ponto, podemos dizer que à parte contra quem se pretenda executar o laudo arbitral deve ter sido oportunizada a possibilidade de intervir na instauração da arbitragem, pelo que deve, ao menos, ter sido cientificada da instauração do processo arbitral. $^{393}$

Tal se dá, na maioria das vezes, nas situações em que se institui a arbitragem por meio de cláusula compromissória, prática comum nas arbitragens internacionais, ocasião em que comumente se delega a uma instituição arbitral a indicação dos árbitros ou do árbitro. Não sendo uma das partes informada desse ato, a instituição da arbitragem se dará e o procedimento correrá sem a presença da parte não notificada, fato que acarretará a não homologação do laudo arbitral decorrente dessa arbitragem.

\footnotetext{
${ }^{393}$ CARMONA, Carlos Alberto, Arbitragem e processo: um comentário à Lei n. 9.307/96, cit., p. 373.
} 
Digna de nota a observação de Carlos Alberto Carmona ${ }^{394}$, segundo o qual não cabe ao órgão judiciário competente para homologar o laudo arbitral estrangeiro, atualmente o Superior Tribunal de Justiça, em observância ao estabelecido neste inciso, verificar se as notificações endereçadas ao réu contra quem se pretende homologar o laudo estrangeiro foram realizadas segundo a lei processual brasileira, mas sim por meio do modelo procedimental que as partes conceberam e avençaram no pacto arbitral.

\subsubsection{A sentença arbitral foi proferida fora dos limites da convenção de arbitragem, e não foi possível separar a parte excedente daquela submetida à arbitragem}

A decisão que for além do estipulado na convenção arbitral para os limites da competência do árbitro não será homologada. Nada obstante, poderá ser oficializada em parte, ocasião na qual "será destacado o conteúdo da decisão que exorbite da competência do tribunal arbitral, concedendo-se oficialização parcial à decisão (ou seja, dá-se o exequatur parcial)". 395

\subsubsection{A instituição da arbitragem não está de acordo com o compromisso arbitral ou com cláusula compromissória}

$\mathrm{O}$ inciso trata unicamente de hipótese relacionada à correta instituição do tribunal arbitral, seja quanto à forma, número de árbitros ou sua qualificação. Na convenção arbitral, as partes estabelecerão o modo de se instituir o juízo arbitral e a escolha dos árbitros, seja por nomeação direta, seja por indicação de terceiros. Assim, tais estipulações devem ser respeitadas tal qual previamente contratadas, pois a opção pela via arbitral cria a justa expectativa para as partes contratantes de que o planejamento quanto à constituição do tribunal arbitral seja respeitado. Assim, não sendo constituído o tribunal arbitral da forma como previamente contratada ou mesmo que uma notificação sobre a constituição do tribunal arbitral não esteja da forma como contratada (inc. III), enseja-se a denegação da homologação do laudo arbitral.

\footnotetext{
${ }^{394}$ CARMONA, Carlos Alberto, Arbitragem e processo: um comentário à Lei n. 9.307/96, cit., p. 373.

395 Ibidem, p. 374.
} 


\subsubsection{A sentença arbitral não se tenha, ainda, tornado obrigatória para as partes, tenha sido anulada, ou, ainda, tenha sido suspensa por órgão judicial do país onde a sentença arbitral for prolatada}

Para que não se configure a hipótese do inciso que ora comentamos, imperioso que o laudo arbitral estrangeiro se tenha tornado obrigatório para as partes, o que não significa dizer que ele tenha se tornado exequível no país de origem. Como já dito anteriormente, tornar-se exequível é requisito para que a sentença estrangeira possa ser homologada, conforme se depreende do artigo 15, “c”, da Lei de Introdução às Normas do Direito Brasileiro.

Há que se ter em mente a distinção entre exequibilidade e obrigatoriedade, e o laudo arbitral se torna obrigatório com a intimação das partes acerca do seu conteúdo. Desse modo, mesmo nas situações em que o país de origem condicione a eficácia do laudo à chancela de seu Poder Judiciário, não há que se falar que ele não se tornou obrigatório para as partes. Tal fato não permite sustentar o indeferimento da homologação.

Segundo Carmona ${ }^{396}$, o objetivo do legislador neste ponto foi evitar que se homologassem laudos ainda não definitivos e, que, portanto, poderiam ainda ser impugnados no âmbito do próprio procedimento arbitral. A possibilidade do laudo ter sido atacado ou mesmo vir a ser atacado mediante demanda anulatória não lhe retira a eficácia, liberada assim que as partes foram intimadas de seu conteúdo. Caso haja suspensão de sua eficácia por medida antecipatória de tutela no país de origem, poderá ser denegada a homologação. Nada obsta, no entanto, que cessados os efeitos da medida antecipatória de tutela de suspensão dos efeitos do laudo arbitral, a demanda homologatória seja novamente proposta, ou mesmo que volte a ser processada, haja vista a possibilidade do Superior Tribunal de Justiça ter apenas suspendido o processo homologatório para aguardar o deslinde da demanda no país onde fora confeccionado o laudo.

Anulado o laudo arbitral no país onde fora editado, será denegada a homologação.

Essas são as disposições contidas no artigo 38 da Lei de Arbitragem, que reproduziu o que constava no artigo V, n. 1, da Convenção de Nova Iorque.

\footnotetext{
${ }^{396}$ CARMONA, Carlos Alberto, Arbitragem e processo: um comentário à Lei n. 9.307/96, cit., p. 376.
} 
O artigo $39^{397}$, por sua vez, estabelece duas objeções processuais e, portanto, cognoscíveis de ofício pelo Superior Tribunal de Justiça, e se referem ao artigo V, n. 2, da Convenção de Nova Iorque. ${ }^{398}$

\subsubsection{Se segundo a lei brasileira, o objeto do litígio não é suscetível de ser resolvido por arbitragem}

Este inciso nos remete ao artigo $1^{\text {o399 }}$ da Lei, que determina que as partes podem valerse do mecanismo extrajudicial de solução de controvérsias tão somente para dirimir litígios relacionados a direitos patrimoniais disponíveis.

O objetivo do legislador foi sem dúvida evitar burla à legislação nacional, que veda sejam resolvidos pela via arbitral litígios não arbitráveis segundo a Lei n. 9.307/96. Fácil seria determinar na convenção arbitral que o laudo, a ser editado visando a pôr fim a controvérsia cujo objeto não seja matéria arbitrável segundo a legislação brasileira, fosse proferido fora do país, para se perpetrar a burla. ${ }^{400}$

A constatação, portanto, de que o objeto do litígio solucionado por meio de arbitragem, cuja decisão se deu fora do território nacional, verse sobre direitos patrimoniais não disponíveis, acarretará a denegação da homologação.

Pouco importará, nesses casos, a legislação escolhida pelas partes para reger as questões de fundo e mesmo o procedimento arbitral, assim também o que a lei do lugar onde foi proferido o laudo estipular como obrigatório. O que importa é o que a legislação nacional dispõe sobre a arbitralidade do objeto do litígio. ${ }^{401}$

\footnotetext{
397 “Art. 39 - Também será denegada a homologação para o reconhecimento ou execução da sentença arbitral estrangeira, se o Supremo Tribunal Federal constatar que: I - segundo a lei brasileira, o objeto do litígio não é suscetível de se resolvido por arbitragem; II - a decisão ofende a ordem pública nacional. Parágrafo único Não será considerada ofensa à ordem pública nacional a efetivação da citação da parte residente ou domiciliada no Brasil, nos moldes da convenção de arbitragem ou da lei processual do país onde se realizou a arbitragem, admitindo-se, inclusive, a citação postal com prova inequívoca do recebimento, desde que assegure à parte brasileira tempo hábil para o exercício do direito de defesa."

398 “Art. V, n. 2 [...] a) segundo a lei daquele país, o objeto da divergência não é passível de solução mediante arbitragem; ou b) o reconhecimento ou a execução da sentença seria contrário à ordem pública daquele país.”

399 "Art. $1^{\circ}$ - As pessoas capazes de contratar poderão valer-se da arbitragem para dirimir litígios relativos a direitos patrimoniais disponíveis."

${ }^{400}$ CARMONA, Carlos Alberto, Arbitragem e processo: um comentário à Lei n. 9.307/96, cit., p. 378.

${ }^{401}$ MARTINS, Pedro A. Batista; LEMES, Selma M.; CARMONA, Carlos Alberto, Aspectos fundamentais da lei de arbitragem, cit., p. 453.
} 


\subsubsection{A decisão ofende a ordem pública nacional}

Como já tratado no capítulo anterior (item. 2.6.5), quando abordamos os requisitos para a homologação das sentenças estrangeiras, a noção de ordem pública é extremamente vaga, comportando ampla margem de valoração subjetiva conferida ao intérprete do direito. Deve-se levar em conta, quando da avaliação da ofensa à ordem pública nacional, os valores eticomorais extraídos do momento sociopolítico vivido e tidos por basilares da convivência da comunidade nacional $^{402}$. Este dispositivo funcionará, com bem disse Nadia de Araújo ${ }^{403}$, como uma barreira à penetração de regras estrangeiras, mesmo que fruto da autonomia da vontade das partes em escolher a legislação aplicável à arbitragem e também decorrentes da aplicação das regras de conexão de direito internacional privado, caso haja flagrante afronta aos direitos fundamentais que o direito interno visa a garantir e proteger.

Fato é que a tendência expressada pela comunidade jurídica internacional é de restringir seu campo de alcance, de modo que a interpretação restritiva deve nortear a interpretação da norma que impede a homologação do laudo arbitral estrangeiro. ${ }^{404}$

Matéria recorrente na doutrina ${ }^{405}$, merece registro a situação dos laudos arbitrais estrangeiros sem fundamentação. Com relação ao laudo arbitral nacional, é indiscutível a necessidade de observância da fundamentação pelo árbitro. Revela-se garantia insuperável, erigida a requisito obrigatório do laudo nacional, segundo o qual as partes devem ter ciência inequívoca das razões que levaram o árbitro a decidir desta ou daquela maneira. Com relação às sentenças judiciais estrangeiras, são raras as situações em que se permite a homologação de sentenças $^{406}$ sem fundamentação, sob o fundamento de que se trata de um requisito de validade da sentença proferida na jurisdição brasileira, de modo que deve ser também exigida para a sentença estrangeira que se pretenda executar no Brasil, na medida que à sentença sem motivação não é dado valor no direito pátrio. E essa tem sido a orientação com relação aos laudos arbitrais estrangeiros. ${ }^{407}$

\footnotetext{
${ }^{402}$ MARTINS, Pedro A. Batista; LEMES, Selma M.; CARMONA, Carlos Alberto, Aspectos fundamentais da lei de arbitragem, cit., p. 454.

${ }^{403}$ ARAUJO, Nadia de, Direito internacional privado: teoria e prática brasileira, cit., p. 112-135.

${ }^{404}$ MARTINS, Pedro A. Batista; LEMES, Selma M.; CARMONA, Carlos Alberto, op. cit., p. 456.

${ }^{405}$ CARMONA, Carlos Alberto, Arbitragem e processo: um comentário à Lei n. 9.307/96, cit., p. 379-381; MARTINS, Pedro A. Batista; LEMES, Selma M.; CARMONA, Carlos Alberto, op. cit., p. 457.

${ }^{406}$ STF - SEC n. 4.415, rel. Min. Francisco Rezek.

${ }^{407}$ CARMONA, Carlos Alberto, op. cit., p. 380.
} 
Ocorre que na arbitragem, sobretudo nas internacionais, envolvendo partes cuja legislação do foro não erige a fundamentação a requisito fundamental, deve-se permitir às partes que dispensem o árbitro de fundamentar a decisão. Tal fato não pode ser visto, sobretudo quando proferida em países em que não se exige a motivação das decisões, como ofensivo à ordem pública.

Carmona $^{408}$ afirma que a jurisprudência que vem se consolidando na Itália, Alemanha, Suíça e mesmo na França, vem mostrando ser possível a concessão do exequatur a decisões arbitrais não motivadas.

Como visto, a interpretação restritiva desta hipótese de indeferimento da homologação deve nortear esta válvula de escape, no intuito de possibilitar, ainda que de forma indireta, como é o caso das decisões estrangeiras, a aplicação do direito estrangeiro escolhido pelas partes em território nacional.

\subsubsection{Citação e a ordem pública nacional}

Digno de nota é o parágrafo único do artigo 39 da Lei de Arbitragem ${ }^{409}$. Dispensa a forma de carta rogatória para a citação da parte domiciliada em território nacional, bastando seja concedido tempo hábil para se manifestar e exercer seu direito de defesa de forma efetiva.

O legislador passa a prestigiar a efetividade do ato em detrimento à forma, o que é de extrema relevância para o sucesso da arbitragem, sobretudo em arbitragens comerciais internacionais, que não mais podem ser refens das formalidades da carta rogatória citatória.

Até o advento da Lei de Arbitragem, sempre foi tida como matéria de ordem pública a citação da parte domiciliada em território nacional por meio de carta rogatória, o desrespeito a essa formalidade impedindo a homologação de laudos arbitrais estrangeiros. ${ }^{410}$

\footnotetext{
408 CARMONA, Carlos Alberto, Arbitragem e processo: um comentário à Lei n. 9.307/96, cit., p. 381.

409 "Parágrafo único - Não será considerada ofensiva à ordem pública nacional a efetivação da citação da parte residente ou domiciliada no Brasil, nos moldes da convenção de arbitragem ou da lei processual do país onde se realizou a arbitragem, admitindo-se, inclusive, a citação postal com prova inequívoca de recebimento, desde que assegure à parte brasileira tempo hábil para o exercício do direito de defesa."

${ }^{410}$ STF - SE n. 4.077, do Reino Unido da Grã-Bretanha.
} 


\section{CONCLUSÃO}

O presente trabalho se desenvolveu sob a ótica do direito internacional, muito embora não se tenha descuidado dos temas que justificam tratamento pela ciência processual civil. Buscou-se em todo momento interpretações tendentes a dar uma maior efetividade às decisões estatais e arbitrais que tenham de ser cumpridas no Brasil, interpretação essa que se deu dentro do contexto dos objetivos do direito internacional privado, visando à estabilidade da vida privada internacional, a manutenção da justiça internacional e a busca de um horizonte sem obstáculos inúteis para o fomento das trocas de riquezas e trabalhos entre os indivíduos dos mais variados países.

Nasce o direito internacional privado com a admissão pelos Estados da possibilidade de aplicação no foro de uma lei que não a sua. Assim, os mesmos fundamentos que justificam aceitar a aplicação direta da lei estrangeira também justificam o reconhecimento das sentenças e laudos arbitrais estrangeiros, dando-se exequibilidade a decisões judiciais provindas de uma jurisdição alheia e, também, a decisões não judiciais que tenham aplicado uma lei escolhida pelas partes, o que importa, em última análise, na aplicação indireta da lei estrangeira, tendo em vista que, embora o direito estrangeiro não se apresente, nesse caso, como norma de conduta abstratamente positivada, aparece como norma já aplicada à hipótese concreta pelo Judiciário de outro Estado.

Como visto, o exercício do poder jurisdicional, enquanto função de Estado, sempre esteve vinculado aos seus próprios limites espaciais, de modo que a jurisdição, historicamente, tem sido exercida a partir da concepção de que o poder de dizer o direito é local em sua base, restrito ao território onde é exercida sua soberania, de modo que inata a vinculação entre jurisdição e soberania política e territorial.

Como exercício da soberania do Estado, a jurisdição poderia ser concebida como absoluta e ilimitada, sendo exercida sempre que provocada e em relação a causas de quaisquer naturezas. No entanto, apesar de manifestação de soberania, o poder jurisdicional não exclui a autolimitação, de modo que o limite imposto à jurisdição, ou seja, a competência, é fruto dessa soberania. 
O Estado, portanto, avoca para si o poder de declarar o direito somente nas hipóteses que lhe forem convenientes, na medida que seria inútil avocar com exclusividade esse poder para todas as causas. Assim o faz em respeito ao espírito internacionalista que deve mover todas as nações, qual seja o de revalidar, revigorar a apreciação feita pela jurisdição estrangeira, cujo pressuposto lógico é a aceitação de que há causas que devem ser submetidas ao poder jurisdicional de Estado de soberania igualmente digna, pois caso assim não fosse, avocaria com exclusividade o poder jurisdicional em relação a todas as causas que pudessem, porventura, lhe interessar. Se limita a sua jurisdição, é porque reconhece como legítimo o poder jurisdicional exercido por outros Estados, cujos provimentos jurisdicionais haverão de ser tão eficazes quanto os seus, o que implica, em última análise, reconhecer na sentença estrangeira uma verdadeira sentença.

Afigura-se, portanto, como interesse da nação, vista como Estado, limitar sua jurisdição em razão da necessidade de convivência com outros Estados, de modo que somente algumas causas lhe interessam julgar, incumbindo ao legislador definir os elementos ou pontos de conexão que, presentes, determinam que a causa se enquadre dentre as submetidas ao poder jurisdicional do Estado. Estabelecem-se, assim, as linhas divisórias da jurisdição do Estado em face da jurisdição de outros Estados, delimitando consequentemente sua competência, dita internacional.

No plano interno, os pontos de contacto previstos nessas normas determinam as causas submetidas à jurisdição nacional, enquanto, por outro lado, no plano internacional, determinam o alcance da jurisdição estrangeira em face da jurisdição nacional, ou seja, o que se admite e o que não se admite que os juízes estrangeiros decidam, o que tem fundamental importância, na medida que a admissão da competência do juiz estrangeiro pelo ordenamento jurídico nacional (lex fori) afigura-se como condição de reconhecimento da sentença estrangeira, conforme se extrai da regra inserta no artigo 15 da Lei de Introdução às Normas do Direito Brasileiro.

Basicamente, nesses casos, pode-se dizer que, o que é muito importante, que se estabelece um pressuposto de homologabilidade no Brasil, de acordo com sua lex processualis, das sentenças proferidas por esses tribunais estrangeiros. Ou seja, imperioso se mostra, para que a sentença estrangeira possa ser homologada pelo Superior Tribunal de 
Justiça, que a autoridade judiciária estrangeira que a tenha proferido não invada a parcela de jurisdição exclusiva das autoridades judiciárias brasileiras.

Com relação à influência da autonomia da vontade sobre as regras de competência internacional do juiz brasileiro, concluímos que não é a simples autonomia da vontade, seja pela mera submissão de uma das partes à jurisdição da autoridade judiciária estrangeira, seja consubstanciada no pacto de eleição de foro internacional, que determina se uma causa está ou não submetida à jurisdição internacional estrangeira ou brasileira, se a uma dessas jurisdições a causa já não estiver submetida por lei, sendo que, especificamente, com relação ao pacto de eleição de foro internacional, embora não vislumbremos permissão legal nas leis editadas em território nacional, o permissivo legal encontra-se no artigo 318 do Código Bustamante.

Uma das consequências práticas, no plano internacional, de se reconhecer a competência concorrente é a possibilidade de submeter a mesma controvérsia a autoridades judiciárias de Estados diferentes, acarretando a possibilidade de duplicidade de demandas, bem como de decisões conflitantes. Muito embora a exceção de litispendência viesse a atuar como instituto remediador dessas situações, mostrando-se extremamente razoável que a admita, sobretudo nos casos em que a lide esteja submetida à jurisdição de uma autoridade judiciária estrangeira, em condições de poder a respectiva sentença ser homologada em território nacional, não é oponível, nesses casos, a referida exceção, a teor do que dispõe o artigo 90 do Código de Processo Civil, o qual, por ser posterior à ratificação do Código Bustamante e com ele colidente, derrogou o seu artigo 394.

Nada obstante, ainda no direito convencional encontramos o artigo 22 do Protocolo de Las Leñas, que permite o manejo da exceção de litispendência, na medida que é norma posterior e especial em relação ao artigo 90 do Código de Processo Civil, e, assim, restrita aos países signatários, de modo que sua aplicação, ou seja, a oposição da exceção de litispendência, restringe-se às ações intentadas somente nesses países e relacionadas às matérias objeto do Protocolo. O artigo 90 do Código de Processo Civil terá plena vigência quando se tratar de outros países, revelando-se norma de caráter geral.

Concluímos, por outro lado, que, de acordo com a premissa adotada de que, ao limitar a extensão da sua jurisdição por meio das regras de competência, o Estado reconhece que a 
outros Estados deva ser submetida a composição de determinadas lides, cujo pressuposto lógico é reconhecer como legítimos esses provimentos jurisdicionais e, portanto, tão eficazes quanto os seus, o que implica em última análise reconhecer na sentença estrangeira uma verdadeira sentença, seria coerente admitir a possibilidade de se arguir a exceção de litispendência, de modo que consideramos o artigo 90 do Código de Processo Civil incongruente com o sistema adotado de limitar o poder jurisdicional do Estado. Não há, de acordo com a coerência do sistema, justificativa plausível para não se admitir e reconhecer a existência de processo em andamento no exterior como legítimo, a evitar que a mesma demanda seja proposta e decidida em território nacional, e que alcançaria, ao menos em tese, o mesmo resultado.

Vimos que o Estado, ao limitar o alcance de seu poder jurisdicional por meio das regras de competência, faz, no plano político, um reconhecimento de que há outras soberanias de igual dignidade. E tal conduta implica em necessariamente reconhecer que os atos jurisdicionais provenientes do poder jurisdicional desses Estados (igualmente soberanos) são tão legítimos e eficazes quanto os próprios, o que impõe considerar a sentença estrangeira como verdadeira sentença, ou seja, a sentença estrangeira como um ato jurisdicional dotado de seus inerentes efeitos.

Paralelamente demonstramos que a coisa julgada atinge o conteúdo declaratório de certeza do direito, sendo que, nas sentenças condenatórias, faz-se necessária a instauração de um procedimento específico para a realização dessa eficácia executiva, ao passo que nas sentenças constitutivas e declaratórias, sua eficácia se realiza como consequência da própria sentença, sem que seja necessária qualquer outra providência jurisdicional.

Concluímos que a eficácia sentencial, própria e inerente à sentença, e que decorre naturalmente da imutabilidade da declaração de certeza jurídica contida no ato sentencial, existe independentemente de qualquer ato jurisdicional. Demonstrou-se, assim, que sentença estrangeira só pode ser considerada como verdadeira sentença se lhe for atribuída de forma indissociável a eficácia imperativa, sem a qual o ato jurisdicional em questão não seria sentença.

E a isso atende o sistema de delibação, que tem como pressuposto lógico e jurídico a concepção de que a sentença estrangeira é verdadeira sentença. Assim não fosse, 
incorreríamos em um verdadeiro absurdo, pois o processo de homologação teria por objeto um ato que deva ser sentença, mas ele próprio atribuiria essa qualidade. Concluímos daí que não é o processo de homologação que confere eficácia à sentença estrangeira. Ela a possui independente de qualquer outro ato do Estado que, porventura, a reconhecerá, pois nos parece incompreensível pretender reconhecer uma sentença que não exista como tal. $\mathrm{O}$ reconhecimento evidentemente pressupõe a realidade do desconhecido.

Desse modo, para os efeitos declaratórios e constitutivos, revela-se desnecessário e mesmo inútil o processo de homologação, na medida que nem toda eficácia da sentença estrangeira depende de uma constituição integrativa, apenas a executiva. Disso resulta que o parágrafo único do artigo 15 da Lei de Introdução às Normas do Direito Brasileiro é coerente com os pressupostos lógicos para a existência do sistema de delibação, que assenta suas bases na concepção de que a sentença estrangeira é verdadeira sentença.

Demonstramos também que o artigo 20 do Protocolo de Las Leñas, uma vez observados os requisitos nele estipulados, permite que as sentenças proferidas pelas autoridades judiciárias dos Estados partes, nas matérias objeto do Protocolo, possuem eficácia extraterritorial, podendo ser apresentada pelas partes diretamente ao juiz da execução do Estado em que deva ser executada, independentemente de qualquer processo de homologação. Concluímos, em razão disso, que a eficácia extraterritorial dada pelo artigo 20 do Protocolo equivale a uma atribuição de jurisdição internacional, ainda que regional, aos tribunais dos Estados partes do Protocolo, evidentemente nas matérias civil, comercial, trabalhista e administrativa.

O mesmo se pode dizer das sentenças internacionais emitidas por tribunais internacionais portadores de jurisdição internacional conferida pelos Estados por meio de convenções ou tratados internacionais. Uma vez assinados, esses tratados ou convenções conferem ao tribunal uma jurisdição internacional, cuja consequência é a eficácia internacional de suas decisões, que, diferentemente das decisões proferidas por tribunais nacionais de outros Estados, não dependem de processo de homologação pelo Superior Tribunal de Justiça para serem executadas.

Vimos que a Lei n. 9.307/96 foi um marco histórico quanto ao desenvolvimento da arbitragem no Brasil. Pôs fim à distinção entre os efeitos da cláusula compromissória e do 
compromisso arbitral, eliminou a necessidade de homologação do laudo arbitral nacional e extirpou o sistema da dupla homologação do laudo arbitral estrangeiro.

No entanto, em coerência com o que equivocadamente fez no plano interno, ao equiparar em efeitos laudo arbitral a sentença judicial, outorgando-lhe o status de título executivo judicial, a Lei de Arbitragem passou a conferir o status de sentença estrangeira ao laudo arbitral estrangeiro, impondo a necessidade da prévia homologação pelo Superior Tribunal de Justiça para que possa ser executado em território nacional.

Justificou-se que a conduta do legislador, ao equiparar laudo arbitral a sentença judicial, se deu em razão da adoção da tese da jurisdicionalidade da arbitragem. Demonstramos, no entanto, que essa característica lhe é inerente e preexistia à edição da Lei n. 9.307/96, e que essa sua característica não lhe altera a natureza contratual e tampouco torna o laudo arbitral um ato oficial.

A manutenção da prévia homologação do laudo arbitral estrangeiro revela, ao menos, um resquício da mentalidade predominante na primeira metade do século $\mathrm{XX}$, de que a jurisdição deveria ser atribuição exclusiva do Estado.

Demonstrou-se que a jurisdição, poder de declarar o direito, é originária dos indivíduos - povo, nação - que a delega ao Estado, o qual, por sua vez, a exerce de maneira concorrente com os indivíduos, e não exclusivamente. Consequência disso é que nem toda decisão, entendida como atividade jurisdicional, detém os mesmos atributos, efeitos e consequências de uma decisão ou ordem estatal, especialmente quando não cumprida. $\mathrm{O}$ fato do árbitro exercer atividade jurisdicional não empresta ao laudo o atributo da oficialidade, próprio das sentenças estatais.

Não se pode desconsiderar, e concluímos ter sido este o equívoco do legislador, que a jurisdição do árbitro tem origem distinta da do juiz togado. Os indivíduos, as partes de um contrato que versa sobre direitos patrimoniais disponíveis, como detentores de jurisdição originária, outorgam, delegam aos árbitros esse poder, para em seu nome, e não em nome do Estado, declarar o direito controvertido sobre aquela relação jurídica de natureza privada. A jurisdição dos árbitros, ainda que também não originária, é privada, não estatal. 
O contrário se dá com a jurisdição do juiz togado, também delegada, mas que provém da Constituição Federal e, assim, da comunidade nacional organizada. Suas decisões serão sempre atos de autoridade pública, atos estatais, oficiais. $\mathrm{O}$ árbitro, ao emitir o laudo, não atua como delegado do Estado, como o faz o juiz togado, mas das partes do contrato.

O laudo arbitral não provém de uma autoridade pública, não decorre de uma prestação jurisdicional de um Estado soberano, não é providência jurisdicional decorrente do exercício do poder jurisdicional delegado pela Constituição como o é a sentença, seja ela nacional ou estrangeira, o que, por si só, desautoriza a exigência de seu reconhecimento por país diverso daquele em cujo território foi proferido. É fruto de uma decisão tomada por árbitros, escolhidos consensualmente pelas partes envolvidas, para dirimir um litígio que envolva direitos patrimoniais disponíveis. E, portanto, não há confusão que se possa fazer quanto aos efeitos do laudo arbitral e da sentença judicial, a ponto de equipará-los.

Há jurisdicionalidade, seja no processo judicial, seja no procedimento arbitral. Ambos, árbitros, pessoas naturais despidas de qualquer autoridade pública, e juízes togados, exercem jurisdição, sem que isso transfigure a natureza privada do laudo arbitral.

O objetivo perseguido pelo legislador poderia ter sido alcançado de outra forma. Como demonstrado, bastaria enquadrá-lo como título executivo extrajudicial, e apenas limitando, à época, as matérias passíveis de arguição em embargos à execução contra a execução (extrajudicial) de laudo arbitral às hipóteses previstas nos artigos 38 e 39 da Lei de Arbitragem, somadas às do artigo 741, então vigente, excluindo a aplicação, especificamente para a execução de laudo arbitral, da regra que permite ao devedor arguir qualquer matéria lícita de ser deduzida como defesa em processo de conhecimento.

Outra possibilidade demonstrada seria incluí-las diretamente no Código de Processo Civil, por meio de um parágrafo inserido no artigo que trata das matérias passíveis de serem arguidas em embargos à execução contra execução de título executivo extrajudicial, restringindo as matérias passíveis de defesa às hipóteses previstas no artigo 741, sem a regra que permite ao devedor arguir qualquer matéria lícita de ser deduzida como defesa em processo de conhecimento, com remissão aos artigos 38 e 39 da Lei n. 9.307/96, ocasião em que o juiz da execução faria uma delibação incidental sobre as hipóteses de indeferimento constantes do artigo 39 da Lei de Arbitragem, e determinaria o prosseguimento da execução, 
para que o executado apresentasse embargos limitados às matérias elencadas no artigo 741 do Código de Processo Civil e no artigo 38 da Lei n. 9.307/96. Ter-se-ia, assim, eliminado a necessidade de homologação prévia pelo Superior Tribunal de Justiça, com o que se privilegiaria ainda mais o instituto, na medida que não lhe retiraria a eficácia de estar apto a instaurar diretamente a execução, sem a dependência de um prévio processo judicial perante aquela corte.

A execução forçada não decorre de imposição legal, mas sim de inércia do devedor em cumprir o laudo, o que torna inevitável o seu manejo nessas situações. Diferentemente ocorre com o procedimento de homologação, requisito imposto pela lei para a execução. Nesse ponto, a homologação parece agir em benefício daquele que hesita em cumprir o laudo, retirando da arbitragem as suas principais qualidades, ou mesmo, tornando inútil sua adoção como mecanismo alternativo de solução de controvérsias.

Como se não bastasse o equívoco do legislador quanto à natureza do laudo arbitral, faz o artigo 35 da Lei de Arbitragem incorrer em inconstitucionalidade, por atribuir competência originária ao Supremo Tribunal Federal à época, e agora ao Superior Tribunal de Justiça, sem o procedimento previsto no artigo 60 da Constituição Federal.

A interpretação dada à sistemática do reconhecimento da sentença e do laudo arbitral estrangeiros se orientou pela necessidade de estabilidade (segurança jurídica) e de justiça da sociedade internacional, no sentido de adequar a legislação e sua interpretação ao cenário econômico, político e social vigente e em constante mutação. É notório que a existência de segurança jurídica nas relações comerciais (e, nesse contexto, se insere a "facilidade" de efetivação de uma decisão em outro país) é motivo de atração de investimentos estrangeiros. Daí porque é autorizado concluir que a desburocratização desse procedimento, evidentemente que atrelado à segurança jurídica, é elemento chave para estreitar os laços comerciais entre o Brasil e seus parceiros econômicos. 


\section{REFERÊNCIAS}

ACCIOLY, Hildebrando. Convenção sobre Arbitragem Comercial Internacional. Revista de Arbitragem e Mediação, São Paulo, Revista dos Tribunais, ano 5, n. 18, p. 245, set. 2008.

Convenção sobre reconhecimento e execução de sentenças arbitrais estrangeiras. Revista de Arbitragem e Mediação, São Paulo, Revista dos Tribunais, ano 5, n. 18, p. 246248 , set. 2008 .

. Projeto de Convenção sobre a execução de sentenças arbitrais internacionais. Revista de Arbitragem e Mediação, São Paulo, Revista dos Tribunais, ano 5, n. 18, p. 239-241, set. 2008 .

Projeto de Convenção sobre a execução das sentenças arbitrais internacionais. Revista de Arbitragem e Mediação, São Paulo, Revista dos Tribunais, ano 5, n. 18, p. 242245 , set. 2008.

ARAUJO, Nadia de. A Convenção de Nova York sobre o reconhecimento e execução de laudos arbitrais estrangeiros: análise das razões contrárias a sua adoção nos anos 50 do século XX. Revista de Arbitragem e Mediação, São Paulo, Revista dos Tribunais, ano 5, n. 18, p. 4249, set. 2008.

Direito internacional privado: teoria e prática brasileira. 5. ed. atual. e ampl. Rio de Janeiro: Renovar, 2011.

ARAUJO, Nadia de (Coord.). Cooperação jurídica internacional no Superior Tribunal de Justiça: comentários à Resolução n. 9/2005. Rio de Janeiro: Renovar, 2010.

ASSIS, Carlos Augusto de; TANAKA, Aurea Christine. Homologação de sentença estrangeira meramente declaratória do estado das pessoas: a propósito do art. 15, par. único, da LICC. Revista de Processo. São Paulo, v. 28, n. 111, p. 81-101, jul./set. 2003.

BARBI, Celso Agrícola. Comentários ao Codigo de Processo Civil: Lei n 5.869, de 11 de janeiro de 1973. Rio de Janeiro: Forense, 1975. v. 1, t. 2.

BASSO, Maristela. Curso de direito internacional privado. 2. ed. rev. e atual. conforme a Lei n. 12.376/2010. São Paulo: Atlas, 2011.

BAPTISTA, Luiz Olavo. A vida dos contratos internacionais. Tese (Concurso de Professor Titular de Direito do Comércio Internacional) - Faculdade de Direito da Universidade de São Paulo, São Paulo, 1992.

BARROSO, Luís Roberto; TIBURCIO, Carmen. Homologação de sentença estrangeira: vedação à expropriação de marcas. Revista da ABPI, Rio de Janeiro, n.80, p. 3-20, jan./fev. 2006. 
BOUCAULT, Carlos Eduardo de Abreu. A competência jurisdicional do Superior Tribunal de Justiça em matéria de homologação de sentença estrangeira. Revista de Estudos Jurídicos UNESP, Franca, SP, v. 11, n.15, p. 23-30, 2006.

Homologação de sentença estrangeira e seus efeitos perante o STF. São Paulo: Juarez de Oliveira, 1999.

CÂMARA, Alexandre Freitas. Arbitragem: Lei n. 9.307/96. 4. ed. rev., ampl. e atual. Rio de Janeiro: Lumen Juris, 2005.

CARMONA, Carlos Alberto. Arbitragem e processo: um comentário à Lei nº 9.307/96. 2. ed. rev. atual. e ampl. São Paulo: Atlas, 2004.

CASELLA, Paulo Borba. Autonomia da vontade, arbitragem comercial internacional e o direito brasileiro. In: TIBURCIO, Carmen; BARROSO, Luís Roberto (Orgs.). Direito internacional contemporâneo: estudos em homenagem ao professor Jacob Dolinger. Rio de Janeiro: Renovar, 2006. p. 737-749.

CASTRO, Amílcar de. Das execuções de sentenças estrangeiras no Brasil. Belo Horizonte: Imprensa Oficial de Minas Gerais, 1939.

Direito internacional privado. 5. ed., 5. tiragem, atual. pelo prof. Osiris Rocha. Rio de Janeiro: Forense, 2000.

CINTRA, Antonio Carlos de Araújo; DINAMARCO, Cândido Rangel; GRINOVER, Ada Pellegrini. Teoria geral do processo. 17. ed. São Paulo: Malheiros, 2001.

CORREIA, António de Arruda Ferrer. Lições de direito internacional privado. Com a colaboração de Luís Xavier. Coimbra: Almedina, 2000. v. 1.

COUTURE, Eduardo. Fundamentos del derecho procesal civil. 3. ed. Buenos Aires: Roque Depalma, 1958.

CRETELLA NETO, José. Curso de arbitragem: arbitragem comercial, arbitragem internacional, lei brasileira de arbitragem, direito privado brasileiro aplicável à arbitragem, instituições internacionais de arbitragem, convenções internacionais sobre arbitragem. 2. ed. Campinas, SP: Milennium, 2009.

DINAMARCO. Cândido Rangel. Direito processual civil. São Paulo: José Bushatsky, 1975.

DOLINGER, Jacob. Direito civil internacional: a família no direito internacional privado: casamento e divórcio no direito internacional privado. Rio de Janeiro: Renovar, 1997. v. 1, t. 1.

Direito internacional privado: parte geral. 9. ed. atual. Rio de Janeiro: Renovar, 2008. 
DOLINGER, Jacob; TIBURCIO, Carmen. Direito internacional privado (parte especial): arbitragem comercial internacional. Com a colaboração de Suzana Medeiros. Rio de Janeiro: Renovar, 2003.

FONSECA, José Roberto da Fonseca. Natureza e eficácia da sentença internacional. In: MERCADANTE, Araminta de Azevedo; MAGALHÃES, José Carlos de (Coords.). Solução e prevenção de litígios internacionais. Porto Alegre: Livraria do Advogado: 1999. v. 2, p. 83100.

FUX, Luiz. Homologação de sentença estrangeira. In: TIBURCIO, Carmen; BARROSO, Luis Roberto (Orgs.). Direito internacional contemporâneo: estudos em homenagem ao professor Jacob Dolinger. Rio de Janeiro: Renovar, 2006. p. 643-649.

GRECO FILHO, Vicente. Homologação de sentença estrangeira. São Paulo: Saraiva, 1978.

HUCK, Hermes Marcelo. Sentença estrangeira e lex mercatoria: horizontes e fronteiras do comércio internacional. São Paulo: Saraiva, 1994.

JO, Hee Moon. Moderno direito internacional privado. São Paulo: Ltr, 2001.

LEMES, Selma M. Ferreira. A homologação de sentença arbitral estrangeira e a citação da parte brasileira. Resultado: Revista de Mediação e Arbitragem Empresarial, Brasília, ano 3, n. 20, ago./out. 2006.

. O reconhecimento da sentença arbitral estrangeira no Brasil. Valor Econômico, 08 ago. 2003, p. E-4.

LIEBMAN, Enrico Tullio. Os limites da jurisdição brasileira. In: Estudos sobre o processo civil brasileiro. São Paulo: Saraiva, 1947. p. 18-26.

LOULA, Maria Rosa Guimarães. A extraterritorialidade das sentenças no Protocolo de Las Leñas sobre cooperação e assistência jurisdicional em matéria civil, comercial, trabalhista e administrativa. In: TIBURCIO, Carmen; BARROSO, Luís Roberto (Orgs.). Direito internacional contemporâneo: estudos em homenagem ao professor Jacob Dolinger. Rio de Janeiro: Renovar, 2006. p. 651-678.

LOULA, Pedro. Breves reflexões sobre a repercussão da Reforma do Judiciário (Emenda Constitucional $\mathrm{n}^{\circ}$ 45/04) no direito internacional brasileiro. In: TIBURCIO, Carmen; BARROSO, Luís Roberto (Orgs.). Direito internacional contemporâneo: estudos em homenagem ao professor Jacob Dolinger. Rio de Janeiro: Renovar, 2006. p. 777-796.

MAGALHÃES, José Carlos de. A cláusula arbitral nos contratos internacionais. Revista de Direito Mercantil Industrial, Econômico e Financeiro, São Paulo, v. 43, p. 29-36, 1981.

Competência internacional do juiz brasileiro e denegação de justiça. Revista dos Tribunais, São Paulo, ano 77, n. 630, p. 52-55, abr. 1988. 
Perspectivas da arbitragem comercial no Brasil. Revista de Direito Mercantil, Industrial, Econômico e Financeiro, Nova Série, São Paulo, Malheiros, v. 27, n. 69, p. 24-30, jan./mar. 1988.

Reconhecimento e execução de laudos arbitrais estrangeiros. Revista dos Tribunais, São Paulo, ano 86, v. 740, p. 116-127, jun. 1997.

O Supremo Tribunal Federal e o direito internacional: uma análise crítica. Porto Alegre: Livraria do Advogado, 2000.

A tardia ratificação da Convenção de Nova Iorque sobre a arbitragem: um retrocesso desnecessário e inconveniente. Revista de Arbitragem e Mediação, São Paulo, Revista dos Tribunais, ano 5, n. 18, p. 24-41, set. 2008.

MAGALHÃES, José Carlos de; BAPTISTA, Luiz Olavo. Arbitragem comercial. Rio de Janeiro: Freitas Bastos, 1986.

MARTINS, Pedro A. Batista. Observações sobre o texto do Acordo sobre Arbitragem Comercial Internacional do MERCOSUL. In: TIBURCIO, Carmen; BARROSO, Luís Roberto (Orgs.). Direito internacional contemporâneo: estudos em homenagem ao professor Jacob Dolinger. Rio de Janeiro: Renovar, 2006. p. 751-776.

MARTINS, Pedro A. Batista; LEMES, Selma M.; CARMONA, Carlos Alberto. Aspectos fundamentais da Lei de Arbitragem. Rio de Janeiro: Forense, 1999.

MESQUITA, José Ignácio Botelho de. Da competência internacional e dos princípios que a informam. Revista de Processo, São Paulo, v. 13, n. 50, p. 51-71, abr./jun. 1988.

. Sentença estrangeira, eficácia e força probante: divorcio no estrangeiro: ausência de homologação, condição do cônjuge divorciado e estudo. Revista de Processo, São Paulo, v. 11, n. 44, p. 223-233, out./dez. 1986.

MIAJA DE LA MUELA, Adolfo. Derecho internacional privado. 6. ed. Madrid: Atlas, 1972.

MOREIRA, José Carlos Barbosa. Comentários ao Código de Processo Civil: Lei $\mathrm{n}^{\circ}$ 5.869, de 11 de janeiro de 1973. 15. ed. rev. e atual. Rio de Janeiro: Forense, 2010. v. 5 (arts. 476 a $565)$.

. A Emenda Constitucional 45/2004 e o processo. Revista de Processo, São Paulo, v. 30, n. 130, p. 235-48, dez. 2005.

Notas sobre o reconhecimento e execução de sentenças estrangeiras. In: TIBURCIO, Carmen; BARROSO, Luís Roberto (Orgs.). Direito internacional contemporâneo: estudos em homenagem ao professor Jacob Dolinger. Rio de Janeiro: Renovar, 2006. p. 549-558.

Problemas relativos a litígios internacionais. Revista de Processo, São Paulo, v. 17, n. 65, p. 144-161, jan./mar. 1992.

NEVES, Celso. Coisa julgada civil. São Paulo: Revista dos Tribunais, 1971. 
PAYNE, Thomas. The Rights of Men. Collector's Edition. Nowark, Conn.: The Eastern Press, 1979.

PEREIRA, Marcela Harumi Takahashi. A sentença estrangeira sem fundamentação pode ser homologada? Revista de Informação Legislativa, Brasília, v. 43, n. 169, p. 203-231, jan./mar. 2005 .

PONTES DE MIRANDA, Francisco Cavalcanti. Comentários ao Código de Processo Civil. Rio de Janeiro: Forense, 1974. v. 6

Tratado de direito privado. Rio de Janeiro: Borsoi, 1971. v. 26.

RAMOS, André de Carvalho. O Reconhecimento da sentença arbitral estrangeira e a cooperação jurisdicional no MERCOSUL. In: CASELLA, Paulo Borba (Coord.). Arbitragem: lei brasileira e praxe internacional. 2. ed. São Paulo: LTr, 1999.

SANTOS, Moacyr Amaral. Primeiras linhas de direito processual civil. 22. ed. rev. atual. por Aricê Moacyr Amaral dos Santos. São Paulo: Saraiva, 2002. v. 1.

SERPA LOPES, Miguel Maria de. Comentários às Leis de Introdução ao Código Civil. 2. ed. rev. e aum. Rio de Janeiro: Freitas Bastos, 1959. v. 1 e 3.

SILVA, Ricardo Perlingeiro Mendes da. Auxílio direto, carta rogatória e homologação de sentença estrangeira. Revista de Processo, São Paulo, v. 30, n. 128, p. 287-292, out. 2005.

SOARES, Guido Fernando da Silva. As arbitragens comerciais internacionais no Brasil: vicissitudes. Revista de dos Tribunais, São Paulo, ano 78, v. 641, p. 29-57, mar. 1989. RT $641 / 29$.

O Supremo Tribunal Federal e as arbitragens comerciais internacionais: "de lege ferenda". Revista de dos Tribunais, São Paulo, ano 78, n. 642, p. 38-71, abr. 1989.

SOUZA, José Ferreira Marnoco e. Execução extraterritorial das sentenças civeis e commerciaes. Coimbra: F. França Amado, 1898.

STRENGER, Irineu. Curso de direito internacional privado. Rio de Janeiro: Forense, 1978.

Direito processual internacional. São Paulo: LTr, 2003.

TENÓRIO, Oscar Accioly. Lei de Introdução ao Código Civil Brasileiro: Decreto-Lei n. 4657, de 4 de setembro de 1942. 2. ed. aum. Rio de Janeiro: Borsoi, 1955.

Direito internacional privado. 7. ed. Rio de Janeiro: Freitas Bastos, 1963. v. 2.

THEODORO JUNIOR, Humberto. Homologação de sentença estrangeira. Revista do Advogado, São Paulo, v. 26, n. 88, p. 75-87, nov. 2006. 
TIBURCIO, Carmen. As inovações da EC 45/2004 em matéria de homologação de sentenças estrangeiras. In: Temas de direito internacional. Rio de Janeiro: Renovar, 2006.

As inovações da EC 45/2004 em matéria de homologação de sentenças estrangeiras. Revista de Processo, São Paulo, v. 31, n. 132, p. 123-139, fev. 2006.

TORNAGHI, Hélio. Comentários ao Código de Processo Civil. São Paulo: Revista dos Tribunais, 1974. v. 1.

VALLADÃO, Haroldo. Direito internacional privado: em base histórica e comparativa, positiva e doutrinária, especialmente dos estados americanos: introdução e parte geral. 3. ed. rev. e atual. Rio de Janeiro: Freitas Bastos, 1971. v. 1.

Direito internacional privado. Rio de Janeiro: Freitas Bastos, 1978. v. 3.

VIGORITI, Vincenzo. Homologação e execução de sentenças e laudos arbitrais estrangeiros na Itália. Revista de Processo, Sao Paulo, v. 13, n. 50, p. 72-87, abr./jun. 1988.

VILLELA, Álvaro da Costa Machado. O direito internacional privado no Código Civil Brasileiro. Coimbra: Imprensa da Universidade de Coimbra, 1921. 